2. Io: (Receiving Organization) Consequence Analys is

5. Proj./Prog./Dept./Div.:

TWRS FSAR

8. Originator Remarks:

Approval and Release of Calculation Note in support of Organic Solvent Analysis for TWRS FSAR and BI0. This document is not be used as the sole basis to authorize activities or to change authorization, safety or design bases.

11. Receiver Remarks: 11A. Design Basel ine Document? [] Yes [X] No

\begin{tabular}{l|c}
$\begin{array}{l}\text { 3. From: (Originating Organization) } \\
\text { TWRS SAR Engineering }\end{array}$ & $\begin{array}{c}\text { 4. Related EDT Mo.: } \\
\text { None }\end{array}$ \\
$\begin{array}{l}\text { 6. Design Authority/ Design Agent/Cog. } \\
\text { Engr.: }\end{array}$ & 7. Purchase Order No.: \\
W. L. Cowley & N/A \\
\hline
\end{tabular}

9. Equip./Component Mo.: N/A

10. Systen/Bldg./Facility: TWRS Tank Farms

12. Major Assm. Dwg. Mo.:

$N / A$

13. Permit/Permit Application Mo.: N/A

14. Required Response Dote: $N / A$

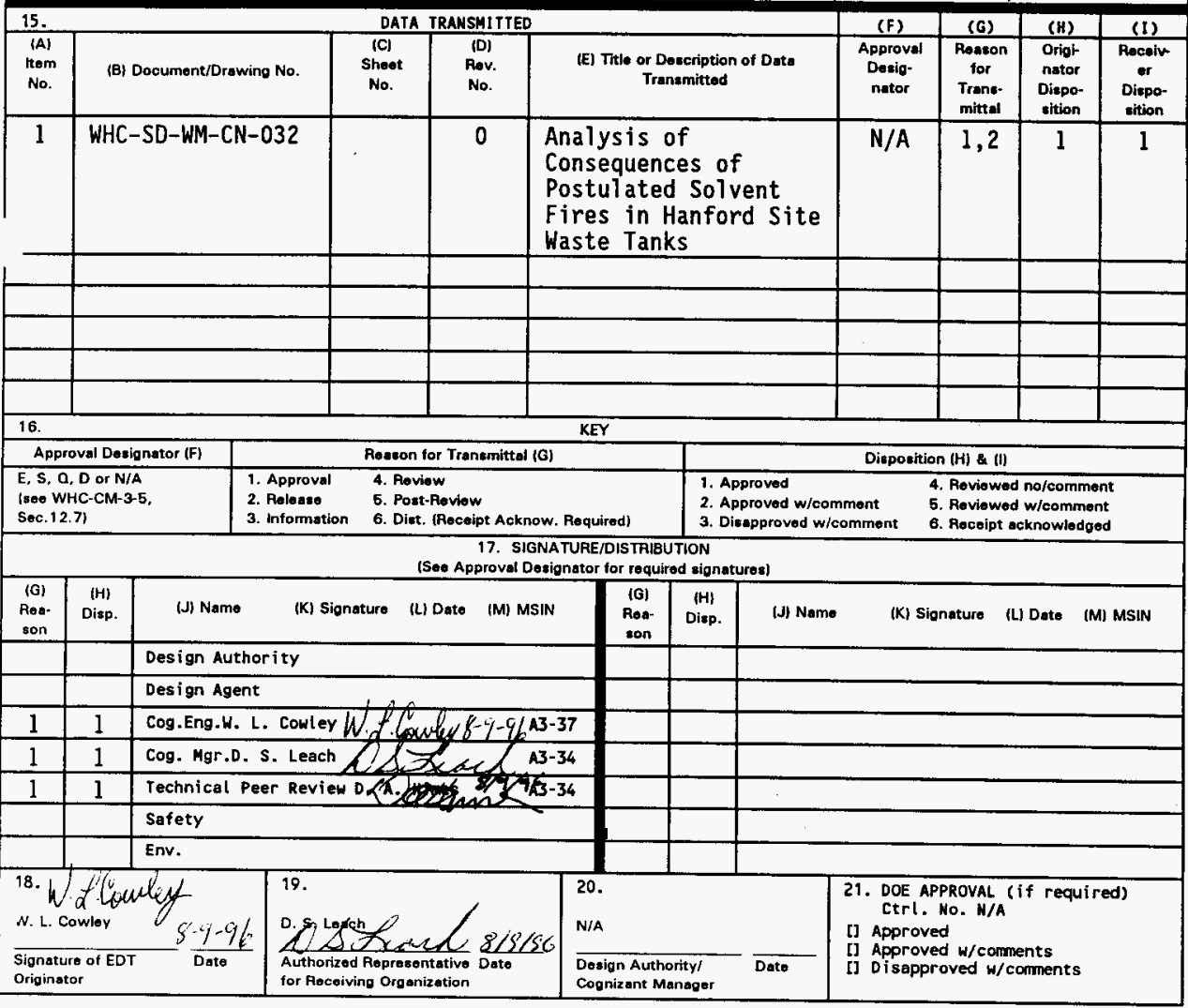




\title{
Analysis of Consequences of Postulated Solvent Fires in Hanford Site Waste Tanks
}

\author{
W. L. Cowley A. K. Postma
}

Westinghouse Hanford Company, Richland, WA 99352

U.S. Department of Energy Contract DE-AC06-87RL10930

\begin{tabular}{|c|c|c|}
\hline $\begin{array}{l}\text { EDT/ECN: } \\
\text { Org Code: } \\
\text { 3\&R Code: }\end{array}$ & $\begin{array}{l}142244 \\
8 M 100 \\
E W 3120074\end{array}$ & $\begin{array}{l}\text { UC: } 2070 \\
\text { Charge Code: } \\
\text { Total Pages: }\end{array}$ \\
\hline
\end{tabular}

Key Words: Organic Solvent, Solvent Fire, Organic Safety

Abstract: This document contains the calculations that support the accident analyses for accidents involving organic solvents. This work was performed to support the Basis for Interim Operation (B10) and the Final Safety Analysis Report (FSAR) for Tank Waste Remediation Systems (TWRS).

IRADEMARK DISCLAIMER. Reference herein to any specific comercial product, process, or service by trade name, tradenark, manufacturer, or otherwise, does not necessarily constitute or imply its endorsement, recommendation, or favoring by the United States Government or any agency thereof or its contractors or subcontractors.

Printed in the United States of Americs. To obtain copies of this document, contact: WHC/BCS Doeument Control Services, P.O. Box 1970, Mailstop H6-08, Rjchland Wh o0z52, phane (500) $372-2 / 20$. Fax (509) 376-4989.
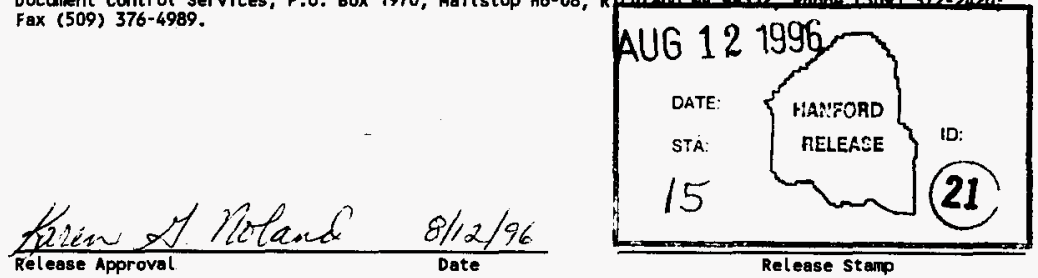

Approved for Public Release 
WHC-SD-WM-CN-032, REV. 0

ANALYSIS OF CONSEQUENCES OF POSTULATED SOLVENT FIRES IN HANFORD SITE WASTE TANKS

W. L. Cowley

A. K. Postma*

August 1996

Westinghouse Hanford Company

Richland, Washington 99352

*G\&P Consulting, Inc., Richland, WA 99352 
WHC-SD-WM-CN-032, REV. 0

This page intentionally left blank. 
WHC-SD-WM-CN-032, REV. 0

\section{CONTENTS}

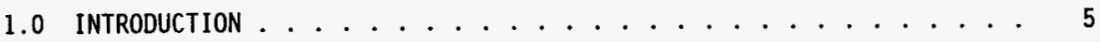

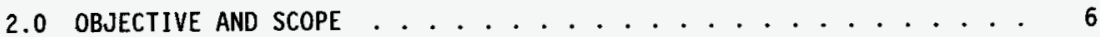

3.0 METHODOLOGY ......................... 7

3.1 DOSE CONSEQUENCES . . . . . . . . . . . . 7

3.2 TOXICOLOGICAL CONSEQUENCES . . . . . . . . . . . 8

3.3 RELEASE OF CONTAMINANTS FROM TANK ............ 10

3.3.1 Solvent Smoke ................. 11

3.3.2 Headspace Gases . . . . . . . . . . . . . . . 12

3.3 .3 Aqueous Boiloff ............... 12

3.4 Frequency of Solvent Fires ............ 13

3.4.1 Physical Parameters That Control Ignition and Burning . 13

3.4.2 Frequency of Solvent Fires . . . . . . . . . 18

4.0 KEY ASSUMPTIONS ....................... 30

4.1 IGNITION AND FLAME SPREAD . . . . ......... 30

4.2 SOLVENT POOL AREA ................... 30

4.3 FIRE EXTINGUISHMENT ................ 30

4.4 TANK PARAMETERS ........................ 30

4.5 TANK STRUCTURAL INTEGRITY ............. 31

4.6 CARRYOVER OF AEROSOLS WITH VENTED GAS ........... . . 31

$5.0 \mathrm{KEY}$ INPUT DATA . . . . . . . . . . . . . . . 32

5.1 RADIOLOGICAL DATA . . . . . . . . . . . 32

5.2 TOXICOLOGICAL DATA . . . . . . . . . . . . . 33

5.2.1 Headspace Gases .............. 33

5.2.2 Fire Reaction Products ............. 33

5.2.3 Tota 7 Particulates . . . . . . . . . . . . 34

5.2.4 HEPA Filter Rupture Toxins . . . . . . . . 34

6.0 SPREADSHEET CALCULATIONS ................... 35

6.1 WORKSHEET 1 . FSAR SOLVENT POOL FIRE CASES ........ 35

5.2 WORKSHEET 2 . DOSE SUMMARY . . . . . . . . . . . . 39

6.3 WORKSHEET 3 . TOXICOLOGICAL . . . . . . . . . . . 43

7.0 RESULTS ........................... 63

7.1 PEAK PRESSURE $/$ VACUUMS $\ldots \ldots \ldots \ldots$

7.2 RADIOLOGICAL FINDINGS . . . . . . . . . . . . 63

7.3 TOXICOLOGICAL FINDINGS . . . . . . . . . . . 63

8.0 CONCLUSIONS . . . . . . . . . . . . . . . 64

9.0 REFERENCES . . . . . . . . . . . . . . . . 65 


\section{LIST OF TABLES}

3-1. Results of S7udge Burning Tests ... . . . . . . . . . . . 17

3-2. Energy Source Frequencies . . . . . . . . . . . . 19

3-3. Solvent Fire Frequencies for Various Organic Solvent Configurations ................... 20

5-1. Radiological Input Data . . . . . . . . . . . 32

5-2. Headspace Gas Data. . . . . . . . . . . . . . 33

5-3. Reaction Product Toxin Limits. . . . . . . . . . . . 34

5-4. Sum of Fraction Multipliers* ............. 34

\section{APPENDIXES}

A DESCRIPTION OF POOLFIRE.3 AND POOLFIRE.4 . . . . . . . . . 67

B SCREENING METHODOLOGY FOR SOLVENT FIRE RISK IN SINGLE-SHELL WASTE TANKS AT THE HANFORD SITE ............. 227 


\subsection{INTRODUCTION}

This report describes in detail the calculational methods used to analyze postulated solvent pool fires in Hanford Site Waste Tanks. Solvent pool fires are one class of accidents considered in Chapter 3.4 of the FSAR.

The solvents studied herein were used in the PUREX process when irradiated fuels were processed at Hanford. Spent solvents, in various quantities, ended up in waste tanks. One tank, C-103, is known to contain a separable solvent layer that floats on aqueous waste. A number of other tanks are thought to contain appreciable quantities of solvent because headspace air samples show the presence of solvent chemical species. The accident studied herein involves the accidental ignition of a pool fire in a tank that contains solvent liquid that is in a combustible configuration, i.e., could support a stable air-fuel flame.

Solvents are composed of a mixture of hydrocarbons, typified by alkanes $\mathrm{C}_{12}$ to $\mathrm{C}_{14}$, and tributyl phosphate (TBP). The flashpoint of the solvents is appreciably higher than waste temperature so solvent vapors contribute only slightly to headspace flammability. Also, ignition of a pool fire requires significant heatup of stored solvent, so a high energy ignitor would be required to initiate a pool fire. Since high energy ignitors are unlikely to be introduced into waste tanks, solvent pool fires are low probability accidents.

To date, no solvent pool fires have occurred in Hanford Site Waste Tanks. The cases analyzed herein are hypothetical, low probability accidents. Potential ignition sources are few, and include the low frequency incidents of lightning strikes, vehicle fuel spill/ignition accidents, and possibly torch cutting accidents. 
WHC-SD-WM-CN-032, REV. 0

\subsection{OBJECTIVE AND SCOPE}

The objective of this report is to describe in detail the calculational methodology used to analyze consequences of postulated solvent pool fires in waste tanks.

The scope of the analysis includes postulated fires in SSTs, DSTs, and DCRTs. All analyses are based on the assumption that tanks remain intact. No consideration has been given to consequences that could result from tank structural damage that could result from mechanical or thermal loads imposed by the postulated accidents. 


\subsection{METHODOLOGY}

This section presents an overview of methodology used to predict possible consequences of solvent fires. Additional details are presented in Section 6 and in the Appendices and Attachments to this report.

\subsection{DOSE CONSEQUENCES}

Onsite dose consequences are calculated on the basis of particle inhalation. The equation used to compute onsite dose is from Van Keuren (1996a):

$$
D(S v)=Q(L) * \frac{\chi}{Q^{1}}\left(s / m^{3}\right) * R\left(m^{3} / s\right) * U L D(S V / L)
$$

where $\quad D=50$ year dose following inhalation, Sv,

$Q=$ Volume of waste dispersed as an aerosol, $L$,

$\frac{\chi}{Q^{1}}=$ Integrated atmospheric dispersion factor, $\mathrm{s} / \mathrm{m}^{3}$,

$R=$ Breathing rate of individual, $\mathrm{m}^{3} / \mathrm{s}$,

ULD = Unit liter dose for released waste, Sv/L.

Total dose was calculated to result from releases attributable to three separate sources:

(1) solvent smoke

(2) waste made airborne by aqueous evaporation

(3) rupture of HEPA and pre-filters.

Offsite dose was computed as the sum of inhalation and ingestion exposures.

$$
D(S v)=D_{I n h}(S v)+D_{I n g}(S v)
$$


Inhalation dose for offsite receptors was computed with Eq.(3-1) using appropriate atmospheric dispersion factors and breathing rates. Ingestion dose was computed from (Van Vleet 1996):

$$
D_{I n g}(S V)=Q(L) * \frac{\chi}{Q^{1}}\left(S / \mathrm{m}^{3}\right) * U L D_{G}\left(S V \mathrm{~m}^{3} / S L\right)
$$

where

$$
\begin{aligned}
D_{I n g} & =50 \text { year dose due to ingestion, } \mathrm{Sv}, \\
Q & =\text { volume of waste dispersed as an aerosol, } \mathrm{L}, \\
\frac{\chi}{Q^{1}} & =\text { atmospheric dispersion factor, } \mathrm{s} / \mathrm{m}^{3}, \\
\mathrm{ULD}_{G} & =\text { unit liter dose for ingestion, } \mathrm{Sv} \mathrm{m}^{3} / \mathrm{sL} .
\end{aligned}
$$

\subsection{TOXICOLOGICAL CONSEQUENCES}

The concentration of toxic substances in the downwind plume was computed from the following formula that applies for continuous releases (Van Keuren 1996b).

$$
C\left(m g / m^{3}\right)=\left(\frac{\frac{\chi}{Q^{1}}\left(\frac{s}{m^{3}}\right)}{1+V^{1}\left(\frac{m^{3}}{s}\right) * \frac{\chi}{Q^{1}}\left(\frac{s}{m^{3}}\right)}\right) * S\left(\frac{m g}{m^{3}}\right) * V^{1}\left(\frac{m^{3}}{s}\right)
$$

where $\quad C=$ peak concentration in plume, $\mathrm{mg} / \mathrm{m}^{3}$,

$S=$ gaseous toxic material source concentration, $\frac{\chi}{Q^{1}}=$ continuous release atmospheric dispersion factor, $\mathrm{s} / \mathrm{m}^{3}$, $V^{1}=$ volume release rate of gaseous source, $\mathrm{m}^{3} / \mathrm{s}$. 
The concentrations computed from Eq. (3-4) were then divided by the risk guideline that applies for each toxin:

$$
F_{i}=\frac{C_{i}}{G_{i}}
$$

where $\quad F_{i}=$ fraction of guideline for $i$-th toxin, dimmensionless,

$C_{i}=$ concentration of $i$-th toxin at downwind receptor, $\mathrm{mg} / \mathrm{m}^{3}$, $G_{i}=$ risk guideline concentration, $\mathrm{mg} / \mathrm{m}^{3}$.

Individual chemical toxins were grouped into the following categories by Van Keuren (1996b), and Grigsby (1995):

- total particulates

- corrosives and irritants

- systemic poisons

- central nervous system toxins

The sum of fractions for each of these categories was then computed as the sum of individual fractions:

$$
S_{c}=\sum_{i=1}^{i=n} \frac{C_{i}}{G_{i}}
$$

where $\quad S_{c}=$ sum of fractions for toxin category, dimensionless,

$C_{i}=$ concentration of $\mathbf{i}$-th toxin in category, $\mathrm{mg} / \mathrm{m}^{3}$,

$G_{i}=$ guideline concentration for $i$-th toxin in category, $\mathrm{mg} / \mathrm{m}^{3}$.

The toxin insult caused by composite materials was evaluated from tabular data presented by Van Keuren (1996b). Composite materials include:

- waste solids

- waste liquids

For these composite materials, the sum of fractions is calculated directly at onsite and offsite locations as a function of the volumetric release rate of these materials. This is illustrated as follows for a release of 1.27E-4 L of SST solids, over a $60 \mathrm{~s}$ time period. The release rate is:

$$
\text { release rate }=1.27 \mathrm{E}-4 \mathrm{~L} / 60 \mathrm{~s}=2.12 \mathrm{E}-6 \mathrm{~L} / \mathrm{s}
$$


For a frequency range of $10^{-4}-10^{-6} \mathrm{yr}^{-1}$, SST solids are characterized by a sum of fractions of $1.0 \mathrm{E} 3 \mathrm{~s} / \mathrm{L}$ (Table 3-8, pg.28 of Van Keuren 1996) for onsite receptors and $1.7 \mathrm{El} \mathrm{s} / \mathrm{L}$ for offsite receptors. The sum of fractions for this specific release of SST solids is thus:

$$
\begin{aligned}
\text { onsite sum } & =2.12 \mathrm{E}-6 * 1.0 \mathrm{E} 3=2.12 \mathrm{E}-3, \\
\text { and offsite sum } & =2.12 \mathrm{E}-6 * 1.7 \mathrm{E} 1=3.6 \mathrm{E}-5 .
\end{aligned}
$$

The overall insult attributable to toxic chemical releases was computed as the sum of fractions for solvent and for tank waste liquids and solids (composite materials).

$$
S_{F}=\sum_{i=1}^{i=5} S_{c i}
$$

where $\quad S_{F}=$ total sum of fractions, dimensionless.

$$
S_{c i}=\text { sum of fractions for ith category. }
$$

To summarize, the five categories of toxic substances included in Eq. (3-7) are:

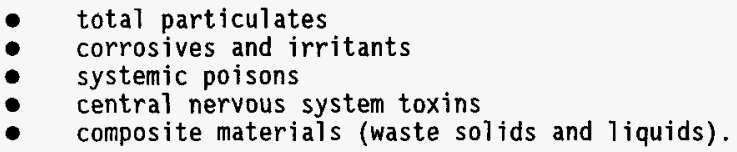

\subsection{RELEASE OF CONTAMINANTS FROM TANK}

The atmospheric source term attributable to postulated solvent pool fires was computed from the following formula.

$$
S=M * C * A R F * R F * L P F
$$

where $S=$ source term, $\mathrm{kg}$,

$M=$ mass of material at risk, $\mathrm{kg}$,

$\mathrm{C}=$ concentration of contaminant in material at risk, $\mathrm{kg} / \mathrm{kg}$, $A R F=$ aerosol release fraction (fraction of contaminant in material at risk which is released as an aerosol), dimensionless, 
WHC-SD-WM-CN-032, REV. 0

$$
\begin{aligned}
& { }^{1} \mathrm{RF}=\text { respirable fraction of released aerosol, dimensionless, } \\
& \mathrm{LPF}=\begin{array}{l}
\text { leak path factor (fraction of aerosol which escapes to the } \\
\text { environment), dimensionless. }
\end{array}
\end{aligned}
$$

Means for quantifying the terms of Eq. (3-8) for the several categories of contaminants are described as follows.

\subsubsection{Solvent Smoke}

The pool fire will cause the airborne release of a fraction of the radionuclide content of the solvent, and will result in the formation of toxic combustion products. Radionuclide release was based on the following quantification of terms in Eq. (3-8).

$M$, the mass at risk, was equated to the mass of solvent burned during the course of the fire. This mass was computed by means of the POOLFIRE. 4 code for each case analyzed. POOLFIRE.4 is described in detail in Appendix A.

$C$, the concentration of radionuclides in solvent was based on measurements performed on a solvent sample retrieved from tank $\mathrm{C}-103$. The analytical measurements are reported by Pool and Bean (1994).

ARF, aerosol release fraction was quantified on the basis of empirical results summarized by Mishima (1994). For large pools, which are predicted to burn to oxygen extinction in minutes, a bounding ARF of 0.03 was used. For small pools (puddles) the burn to oxygen extinction is predicted to take many minutes, allowing time for heatup of underlying waste. A higher ARF of 0.1 was selected from the data Mishima (1994) for puddle fires.

RF, the respirable aerosol fraction was conservatively assumed to be unity for all cases.

LPF, the leak path transmission factor, was calculated by POOLFIRE. 4 for each case analyzed. Retention was credited only on the basis of incomplete venting of headspace gases during the fire cycle. Aerosol depletion, which would likely be significant for the puddle fires, was conservatively neglected.

Toxic gas species formed by combustion of solvent were assumed to be adequately represented by $\mathrm{CO}, \mathrm{NO}_{2}$, and $\mathrm{P}_{2} \mathrm{O}_{5}$. For $\mathrm{CO}$ and $\mathrm{NO}_{2}$, emission factors were used to quantify the masses formed by combustion. Emission factors used for $\mathrm{CO}$ and $\mathrm{NO}_{2}$ were 0.0425 and $5.5 \mathrm{E}-3$ respectively from Grigsby et al. (1995). The emission factor is defined as the mass of pollutant formed per mass of fuel burned. $\mathrm{P}_{2} \mathrm{O}_{5}$ formation was quantified by stoichiometry for the oxidation of TBP:

1 RF has been assigned a bounding value of unity for all cases analyzed, so its use does not have an impact on calculated consequences. RF is retained in this report because RF could be important in realistic analyses. 


$$
\mathrm{C}_{12} \mathrm{H}_{27} \mathrm{PO}_{4}+18 \mathrm{O}_{2}=12 \mathrm{CO}_{2}+13.5 \mathrm{H}_{2} \mathrm{O}+0.5 \mathrm{P}_{2} \mathrm{O}_{5}
$$

Based on Eq. (3-9), the mass ratio of $P_{2} 0_{5}$ to TBP is 0.27 . TBP vapors were assumed to comprise $16 \%$ by mass of fuel burned. This vapor mass fraction was taken from measurements at $100{ }^{\circ} \mathrm{C}$ reported by Pool and Bean (1994) for solvent samples retrieved from tank $\mathrm{C}-103$. Therefore an emission factor for $\mathrm{P}_{2} \mathrm{O}_{5}$ is $0.27(0.16)=0.0432 \mathrm{~kg} \mathrm{P}_{2} \mathrm{O}_{5} / \mathrm{kg}$ fuel.

The LPF value computed from POOLFIRE.4 was used for toxic gas releases. RF was assigned a value of unity.

\subsubsection{Headspace Gases}

Headspace gases can contain a number of toxic substances. A bounding (worst case), steady state composite was assumed in all cases analyzed herein. The composition of headspace gases is quantified by Van Keuren (1996b). LFP was calculated by POOLFIRE.4 and RF was conservatively assigned a value of unity.

Radioactive content of headspace air prior to a pool fire was neglected.

\subsubsection{Aqueous Boiloff}

The pool fire could cause aerosolization of waste by evaporating water or possibly by entrainment due to air flow. While the pool fire would result in a fire plume that would induce air circulation in the headspace, air velocities near the surface of the waste outside the burning pool are judged to be too low to cause appreciable waste entrainment. Therefore entrainment of waste due to air flow at the surface of the waste is discounted. Waste aerosolization due to moisture evaporation is quantified on the basis of releases from boiling liquids.

The mass of liquid at risk is computed as the mass of water which could be evaporated by heat transferred from the flame to the inflamed surface. Using a flame heat transfer rate of $57 \mathrm{kw} / \mathrm{m}^{2}$ (an average of values for burning of rubber gloves and burning of kerosene (Ayer et al. 1988), an average specific burning rate of $1.2 \mathrm{~kg} / \mathrm{m}^{2} \mathrm{~min}$ (Jordan and Lindner 1983), and a latent heat of water of $2.26 \mathrm{MJ} / \mathrm{kg}$, the mass of water evaporated per mass of fuel burned is:

$$
\frac{57 \mathrm{~kJ}}{s \mathrm{~m}^{2}} * \frac{60 \mathrm{~s}}{\min } * \frac{\mathrm{m}^{2} \mathrm{~min}}{1.2 \mathrm{~kg} \mathrm{fuel}} * \frac{1 \mathrm{~kg} \mathrm{H} \mathrm{O}^{\circ}}{2260 \mathrm{~kJ}}=\frac{1.26 \mathrm{~kg} \mathrm{H} \mathrm{H}_{2}}{\mathrm{~kg} \mathrm{fuel}}
$$

The value of M applicable to aqueous boiloff in Eq. (3-8) was computed for each case by multiplying the mass of fuel burned (from POOLFIRE.4) by 1.26 . 
ARF, aerosol release fraction, was assigned a value of 0.002 on the basis of release fractions for boiling liquids as recommended by Mishima (1994). Respirable fraction, RF, was assigned a conservative value of unity for all cases. LPF, leak path admittance factor, was computed in POOLFIRE.4 to account for the fraction of reaction products vented from the tank over the course of the fire. No credit was taken for aerosol depletion.

The concentrations of nuclides in SST, DST, and DCRT 1iquids, expressed in terms of unit liter doses, were based on values recently reported by Cowley (1996). The concentration of toxic analytes in these liquids was evaluated from sum of fraction per unit release rate data presented by Van Keuren et al., (1996b).

\subsection{Frequency of Solvent Fires}

\subsubsection{Physical Parameters That Control Ignition and Burning}

Separable phase organic liquids can form a combustible situation by (1) being present as a free pool (or puddle) on the waste surface, or (2) collecting in sufficient concentrations entrained in the waste solids to form a combustible area at the waste surface by capillary or wicking behavior. At least a portion of the organic solvent pool must be heated above its flashpoint in order for a poot fire to be ignited. This requires an energy source. Solvent temperatures in waste tanks are expected to be well below the solvent flashpoints.

- The solvent in tank $241-\mathrm{C}-103$ is at a temperature of $\approx 40{ }^{\circ} \mathrm{C}$ or $\approx 75{ }^{\circ} \mathrm{C}$ below its measured flashpoint of $118{ }^{\circ} \mathrm{C}$.

- The solvent in tank $241-\mathrm{C}-102$ is $\approx 90{ }^{\circ} \mathrm{C}$ below its expected flashpoint of $118{ }^{\circ} \mathrm{C}$ (the solvent in tank $\mathrm{C}-102$ is expected to be similar to that in $\mathrm{C}-102)$.

- The waste surface temperature in tank $241-\mathrm{BY}-108$ is $\approx 30{ }^{\circ} \mathrm{C}$, therefore, well below the flashpoint of degraded PUREX solvent.

Large pools of solvent would be difficult to ignite as the heat added to the pool by an energy source is convected away and returned to the tank headspace. This heat dissipation is very effective for pools and larger puddles. Solvent-filled channels or cracks and solvent permeated saltcakes and sludges may be more easily ignited, as convective flow is restricted.

Possible solvent pool configurations (e.g., pools, puddles, solvent permeated sludge or saltcake) that may exist in waste tanks are evaluated for their ease or difficulty of ignition. Credible energy sources are then evaluated to estimate solvent fire ignition frequencies.

3.4.1.1 Ignitibility of Organic Solvent. Organic liquid (e.g., that currently present in tank $(-103)$ can only be made to burn with great difficulty when the initial liquid temperature is below the flashpoint. The question addressed here is the required initiating energy source necessary to cause ignition of an initially cool organic pool where cool means many tens of degrees below the flashpoint. 
Local heating of a 1 iquid layer induces liquid convection due to changes in the surface tension brought on by the rising temperature. Strong convective flows at and near the liquid surface carry heat away from the source (assumed at or above the liquid surface), losing heat convectively to the atmosphere above. A cool return flow runs countercurrent beneath the liquid surface. Local heating must be sufficient to at least bring the local surface to a temperature above the flashpoint so that ignition can occur locally. The ignited region must also be large enough to cause flame spreading.

This convective loss mechanism is not effective when liquid organic is embedded in sludge or saltcake, so ignition by local heating is easier. Ignition can, however, be hindered or possibly prevented by the presence of water in the wastes. The various key aspects of solvent ignitability are studied through experiments and theoretical analysis as described in Appendix $B$ and summarized below.

3.4.1.2 Organic Liquid Pools. The conditions for ignition of organic liquid pools, either as residual layers atop sludge or water, have been investigated experimentally and analytically. Ignition of a pool requires that (1) an energy source locally heats the liquid to a temperature above its fiashpoint, (2) this heat ignites the vapors, and (3) the size of this locally-heated region is large enough to sustain combustion (i.e., to prevent flame extinction). Since flame extinction or flame spreading may occur, depending on the region size, the latter condition is equivalent to stating that the energy source must locally heat and ignite a region of sufficient size to allow flame spreading on the remaining cool pool liquid. Only a few hypothetical scenarios exhibit the conditions for ignition of a cool poot.

- Robust heating of a free pool surface--The size of the heated region must be sufficient enough for the locally-ignited fire to spread to the rest of the subcooled pool. Based on experiments and analys is described in WHC-SD-WM-SARR-036, Appendix B, the heat source must be large enough to raise at least a $10-\mathrm{cm}-$ diameter region of solvent above its flashpoint. The power applied needs to be enough to overcome the convective heat losses. The power required can be quantified based on experiments and theory described in WHC-SD-WMSARR-036, Appendix D. The required power is a function of the solvent depth, increasing with depth. Layers less than $2 \mathrm{~mm}$ in depth have been shown to be non-ignitable. The solvent pulls away from the heat source exposing the underlying waste or aqueous liquid rather than heating to the flashpoint. The energy source power requirements to reach ignition conditions are calculated in WHC-SOWM-SARR-036, Appendix C. Assuming dodecane properties (which is conservative for the calculation relative to degraded PUREX solvent), a layer slightly deeper than $2 \mathrm{~mm}$ requires at least 200 watts of heat to be radiated to the solvent from a $10-\mathrm{cm}$-diameter heat source suspended directly above the solvent. A 5-mm-deep layer requires at least 1700 watts.

- Heating and ignition of a confined region--A region of the pool must be confined to prevent convective heat losses to the remaining liquid. The region must also be bulk heated to at least the liquid flashpoint in order to be ignited, and the radiant heat from this 
WHC-SD-WM-CN-032, REV. 0

region must be sufficient to allow flame spread to the neighboring pool area. The confined region must be large enough that its radiant heat loss causes ignition nearby. This is an unlikely event unless the barrier responsible for fuel layer confinement is removed.

Confined regions from which flame spreading is possible must be (1) at least $10 \mathrm{~cm}$ in diameter and greater than $2.0 \mathrm{~mm}$ in depth, and (2) gradually and uniformly heated to the flashpoint. A reasonable bounding minimum energy for such a layer is $2 \mathrm{~kJ}$ (see WHC-SD-WMSARR-036, Appendix C). The actual initiator energies would be larger if the puddle was deeper than $2 \mathrm{~mm}$.

- Sustained burning of a larqe object--A burning object that produces radiant energy equivalent to burning the confined region described above would also be sufficient to cause ignition of the adjacent pool. The burning object is thus considered to have the same characteristic dimension as the burning confined region. A burning object must, therefore, be at least $10 \mathrm{~cm}$ in diameter to cause $\mathrm{flame}$ spreading.

- Spark initiation--This differs from the previous initiators by timescale. A spark deposits a large amount of power in a local area over a brief period of time, whereas the other initiators are more sustained. The rapid transfer of energy to the solvent pool surface may raise the pool surface temperature to the flashpoint with little heat conducting to lower regions of the pool. The amount of energy needed to create a small flammable vapor cloud above the pool surface may therefore be much less, theoretically, than that required to slowly heat the solvent pool to the flashpoint. Spark energy must exceed $2.0 \mathrm{~J}(0.2 \mathrm{MW}$ spark power) in order to produce a 10 -cm-diameter, potentialiy flammable zone above the pool surface (see WHC-SD-WM-SARR-036, Appendix B).

\subsubsection{Small Solvent Puddles and Solvent Filled Cracks}

Small puddles--As puddle size is decreased, the convective flow of the solvent away from the heat source becomes constrained and the heat rejection capability of the puddle is reduced. The energy source needed to heat the puddle up to the flashpoint is therefore reduced from the extremely large sources needed to ignite a large pool. Testing performed in a $0.6-\mathrm{m}$-diameter pan indicated that the solvent under a heater was not raised to flashpoint temperatures for radiant heating up to 90 watts, the maximum tested WHC-SD-WM-SARR036, Appendix B. Ease of ignition for smal1 puddles is, however, bounded by solvent-filled cracks and solvent permeated saltcakes as described below.

Solvent-Filled Cracks--Organic solvent in cracks or channels in a sludge surface are confined to essentially one-dimensional convective flow for heat rejection, therefore, ignition and flame spreading is easier in a narrow channel than it is in an open pool. This is demonstrated in WHC-SD-WM-SARR-036, Appendix B, by a onedimensional version of the thermocapillary convection analysis and 
WHC-SD-WM-CN-032, REV. 0

by some quantitative and qualitative experiments on convection and flame spreading, respectively. Propagation of a fire from a narrow channel into an open pool, however, is subject to the same flame size constraints discussed above for pools. On the other hand, fuel in a large pool connected to a burning channel may continuously supply fuel to the channel. These observations are summarized as follows.

- Relatively small initiators may start fires in narrow cracks filled with tank waste solvent.

- These fires may continue as fuel from the pool flows back to the cracks.

- Fires in cracks or channels cannot propagate into open pool areas unless the characteristic crack size exceeds the pool fire spreading threshold criterion.

- Consequence analysis discussed in Section 6.0 shows that fires in cracks with limited surface area could not threaten tank integrity.

Experimental Observations--A series of tests has been performed for relatively narrow $(1.3$ to $1.5 \mathrm{~cm}$ ) channels (see WHC-SD-WM-SARR-036, Appendix B). Such channels filled with dodecane could not be ignited with a small oxyacetylene torch. Wick-stabilized flames started at one end of the channel failed to cause flame propagation up the channel. Testing with radiant heaters determined that a channel filled with solvent could convect significant heat away from a heat source. A few tens of centimeters of channel length were adequate to dissipate more than $30 \mathrm{~kW} / \mathrm{m}^{2}$ of radiant heating applied to one end of a $1.3-\mathrm{cm}-$ wide channe1. Igniting the channel required that the heated solvent be confined by a barrier to prevent convective cooling. Even though small puddles and channels are easier to ignite than a large puddle or pool, a sizeable, sustained heat source is still required to cause ignition.

Ignition of smali puddles by hot particles and pyrotechnic "electrical matches" has also been attempted. The testing is described more in WHC-SD-WM-SARR-036, Appendix $C$. The test involved 6.3-cm-diameter puddles of dodecane. Applying the $138 \mathrm{~J}$ electrical match did not result in ignition. Dropping heated steel balls of various sizes into the puddle also did not result in ignition. The steel balls varied in size $(1 / 16,3 / 32$, and $3 / 16$ in. diameter) and were heated to about $1300{ }^{\circ} \mathrm{C}$. This corresponds to energies of 10 , 35 , and $270 \mathrm{~J}$, respectively.

3.4.1.4 Organic Liquid Entrained in sludge. The sludge in most tanks, including tank $\mathrm{C}-103$, is expected to retain significant water following saltwell pumping. It is most likely that such a sludge mixture is impossible to ignite due to the preponderance of water relative to entrained or embedded solvent. Solvent ingression experiments conducted with tetradecane/TBP organic atop water-saturated, kaolin sample materials (FAI 1994), are described below and in more detail in WHC-SD-WM-SARR-036, Appendix B. 
WHC-SD-WM-CN-032, REV. 0

Solvent permeated sludge simulants were prepared and tested for ignitability. Samples were prepared by mixing moist sludge (moisture was varied) with an organic liquid mixture of $70 \%$ TBP and $30 \%$ tetradecane $\left(C_{14}\right)$. A summary of the estimated bounds on the entrained organic content in the sludge, both on a dry mass basis and in terms of percentage TOC, is presented in Table 3-1. Note that the sludge samples were uniform in color (i.e., tan) and appearance (i.e., moist), and there was no free liquid on the sample surface or in cracks in the (partially consolidated) sludge.

After characterizing the surrogate sludge samples in terms of embedded organic content, an attempt was made to ignite the sludge. Ignition was attempted using a small oxyacetylene torch. These results are also presented in Table 3-1.

In general, the samples with the most organic (and the least moisture) were the easiest to ignite, but even the sample with $17 \%$ TOC (nominal) required some effort (prolonged heating) to establish a self-sustained flame. Even then, the flame self-extinguished after -15 seconds, and samples with nominal TOC contents of 14,12 , and $8.5 \%$ only burned independently for about five, three, and one second(s), respectively. With the torch in place, these samples showed visible signs of fuel burning in the vicinity of the torch jet, particularly for higher fuel contents. A self-sustained flame could not be established on the samples with 4.5 and $2 \%$ TOC, and even with the torch in place there was little, if any, visual evidence of fuel burning.

In summary, the samples that sustained burning did so only briefly, consuming only a fraction of the available fuel before self-extinguishing. Re-applying the torch jet allowed the process to repeat itself. Samples that contained more than $20 \%$ water did not ignite at all. The presence of water is likely the most important factor in preventing sustained burning of organic in sludge. It is concluded that sludge containing more than $20 \%$ water will not ignite and support a sustainable solvent fire.

Table 3-1. Results of Sludge Burning Tests.

\begin{tabular}{|c|c|c|c|c|c|c|}
\hline Test ID & 3 & 7 & 6 & 2 & 5 & 4 \\
\hline $\begin{array}{l}\text { Simulant composition } \\
\text { sample net (g) } \\
\text { wt \% kaol in } \\
\text { wt \% water (max/min) }\end{array}$ & $\begin{array}{c}94.8 \\
70 \\
29 / 27\end{array}$ & $\begin{array}{c}93.6 \\
72 \\
23 / 22\end{array}$ & $\begin{array}{l}95.4 \\
72 \\
18 / 16\end{array}$ & $\begin{array}{c}92.7 \\
72 \\
13 / 11\end{array}$ & $\begin{array}{l}90.5 \\
72 \\
8 / 6\end{array}$ & $\begin{array}{l}97.4 \\
71^{4} \\
4 / 2\end{array}$ \\
\hline $\begin{array}{l}\text { Organic content (wet basis) } \\
\text { wt } \% \text { organic (min/max) } \\
\text { wt \% TOC (min/max) }\end{array}$ & $\begin{array}{l}1 / 3 \\
1 / 2\end{array}$ & $\begin{array}{l}5 / 6 \\
3 / 4\end{array}$ & $\begin{array}{c}10 / 12 \\
6 / 8\end{array}$ & $\begin{array}{l}15 / 17 \\
9 / 11\end{array}$ & $\begin{array}{l}20 / 22 \\
13 / 14\end{array}$ & $\begin{array}{l}25 / 27 \\
16 / 17\end{array}$ \\
\hline $\begin{array}{l}\text { Organic content (dry basis) } \\
\text { wt \% Organic (min/max) } \\
\text { wt \% Toc (min/max) } \\
\text { Nominal \% Toc }\end{array}$ & $\begin{array}{c}2 / 4 \\
1 / 3 \\
2\end{array}$ & $\begin{array}{l}6 / 8 \\
4 / 5 \\
4.5\end{array}$ & $\begin{array}{l}12 / 15 \\
7.5 / 9.5 \\
8.5\end{array}$ & $\begin{array}{l}17 / 20 \\
19 / 13 \\
12\end{array}$ & $\begin{array}{l}21 / 24 \\
93 / 15 \\
14\end{array}$ & $\begin{array}{l}25 / 28 \\
16 / 18 \\
17\end{array}$ \\
\hline $\begin{array}{l}\text { Igni tability } \\
\text { Short-duration } \mathrm{fl} \text { ame } \\
\text { Burn duration }(\mathrm{sec})\end{array}$ & $\begin{array}{l}N \\
.-\end{array}$ & $\begin{array}{l}N \\
-.\end{array}$ & $\begin{array}{l}Y \\
1\end{array}$ & $\begin{array}{l}Y \\
3\end{array}$ & $\begin{array}{l}Y \\
5\end{array}$ & $\begin{array}{c}Y \\
15\end{array}$ \\
\hline
\end{tabular}

TOC = Total organic carbon. 
3.4.1.5 Organic Liquid Entrained in Saltcake. Waste salt cakes are expected to retain less moisture than sludges and assumed to be able to contain more solvents in interstitial pores than sludges. Scoping tests with saltcake simulants saturated with kerosene indicted that when the saltcake-kerosene mixture was heated near on open flame, the kerosene ignited after reaching its flashpoint, and burned (Beitel 1977). The salt cake, however, did not participate in the reaction other than to serve as a wick.

Scoping tests indicated that solvent could be ignited above saltcake simulants, where the solvent would wick to the surface and burn in air until the solvent was largely consumed. Ignitability tests were, therefore, performed to better quantify ignition source requirements for saltcake-solvent mixtures. The results of this testing are described in WHC-SD-WM-SARR-036, Appendix $D$ and summarized below.

Tests involved introducing a pyrotechnic "electric match" and heated steel balls to a dodecane saturated saltcake simulant $6.35 \mathrm{~cm}$ in diameter. Neither the $138 \mathrm{~J}$ match or any of the heated steel balls (energy ranging from $10 \mathrm{~J}$ to $270 \mathrm{~J}$ ) caused the solvent saturated saltcake to ignite. It is therefore concluded that small heated objects and sparks can not ignite solvent saturated saltcake. A larger, more sustained energy source is required.

3.4.1.6 Conclusion. Liquid organic solvent is difficult to ignite in any configuration, from large open pools, to small confined channels. It is even more difficult to achieve the conditions necessary for a self-sustaining fire. In theory, it is easier to ignite and sustain an organic solvent fire when the solvent is confined, such as in a small channel. However the laboratory tests cited show that robust ignition sources are required even for confined cases, such as channels.

Solvents entrained in saltcake or sludge can burn, using the saltcake or sludge as a wick. It requires less energy to ignite and sustain a wick stabilized flame.

\subsubsection{Frequency of Solvent Fires}

The following summarizes an evaluation of tank farm equipment and operations, including operational upsets and natural phenomena, that might act as initiators for a solvent fire in a waste tank. The energy source frequencies are combined with ignition probabilities, given the energy source is present, to assign ignition frequencies for solvent fires.

Operations that were considered in this evaluation are described in Bajwa and Farley (1994). In addition, the tank farm operations procedures described in the computer network-based, online Tank Farms Procedure Information System were reviewed for additional operations that would involve heating potential.

The evaluation was performed in three steps. First the operations (normal and upset conditions) and natural phenomena were evaluated to determine which operation could introduce significant energy into the waste tank. Energy must be added to the waste to heat and vaporize a portion of the organic solvent and to create local high temperatures to act as an ignitor. 
Secondly, the frequency of the energy being deposited into the waste is estimated. Finaliy, the probability that the energy source could initiate a sustainable organic fire is estimated. The energy required to ignite a solvent pool or large puddle is quite large, while the energy required to ignite a small puddle or solvent-filled crack is somewhat smaller, and the energy required to ignite solvent permeated saltcake is smaller still (see Section 3.4.1). The results of the evaluation are summarized in Tables $3-2$ and 3-3 and described in Sections 3.4.2.1 through 3.4.2.8.

Table 3-2. Energy Source Frequencies.

\begin{tabular}{|l|c|}
\hline \multicolumn{1}{|c|}{ Energy source } & Frequency (events/tank-yr) \\
\hline a. Electrostatic sparks between equipment and waste & 1 \\
\hline $\begin{array}{l}\text { b. Instrumentat ion faults cause over current in } \\
\text { Waste }\end{array}$ & $1.0 \mathrm{E}-1$ \\
\hline c. Welding and grinding sparks fall to waste surface & $1.0 \mathrm{E}-2$ \\
\hline d. Torch cutting & $1.0 \mathrm{E}-02$ \\
\hline e. Camera and light power supply shorts in waste & $1.0 \mathrm{E}-3$ \\
\hline $\begin{array}{l}\text { f. Vehicle fuel spill causes a gasol ine fire inside } \\
\text { the waste tank }\end{array}$ & $7 \mathrm{E}-5$ \\
\hline g. Lightning strike arcs to waste surface & $3 \mathrm{E}-5 \cdot$ \\
\hline h. Core drill overheating & $1.0 \mathrm{E}-4$ \\
\hline i. Submersible pump overheating & $1.0 \mathrm{E}-8$ \\
\hline
\end{tabular}

"Frequency is for an SST. It is not credible for lightning to are to the waste surface in a DST or DCRT.

3.4.2.1 Electrostatic Sparks. In order for a static electricity discharge to ignite a fire involving combustible liquids, the vapors above the liquid need to be flammable (i.e., the liquid needs to be at or above its flashpoint) and the spark energy needs to be greater than the minimum ignition energy. Static sparks cannot ignite liquids that are well below their flashpoint, as is the case with the solvent in tanks $\mathrm{C}-103$ and $\mathrm{BY}-108$.

Electrostatic charge may build up on an object that is an isolated insulator. The electrostatic spark energy potential is a strong function of the capacitance of the object, which increases with the size of the object. A review of electrostatic spark energies for typical industrial situations in Dust Explosions in the Process Industries (Eckhoff 1991) indicated that a high-end spark energy is $0.45 \mathrm{~J}(0.05 \mathrm{MW})$ which is attributed to a very large object such as a road tanker (i.e., truck). This energy is well in excess of the maximum theoretical spark energies expected from discharge of various types of objects that may be inserted into a waste tank. A spark source initiator must be very large, and therefore, spark sources in the waste tanks other than lightning are not considered to be credible initiators. The probability that an electrostatic spark could ignite the solvent in the tanks is, therefore, assigned a value of zero. 
Table 3-3. Solvent Fire Frequencies for Various Organic Solvent Configurations.

\begin{tabular}{|c|c|c|c|}
\hline $\begin{array}{c}\text { Solvent } \\
\text { configuration }\end{array}$ & Energy source & $\begin{array}{c}\text { Solvent fire } \\
\text { ignition } \\
\text { probabilities }\end{array}$ & $\begin{array}{c}\text { Solvent fire } \\
\text { frequency } \\
\text { (events/tank-yr) }\end{array}$ \\
\hline I. Floating pool & $\begin{array}{l}\text { a. Electrostatic sparks } \\
\text { b. Instrumentation faults } \\
\text { c. Welding and grinding sparks } \\
\text { d. Torch cutting } \\
\text { e. Camera and light power supply } \\
\text { shorts } \\
\text { f. Vehicle fuel fire } \\
\text { g. Lightning strikes } \\
\text { h. Core drill overheating }\end{array}$ & $\begin{array}{ll}\text { l.a. } & 0 \\
\text { l.b. } & 0 \\
\text { l.c. } & 0 \\
\text { l.d. } & 0 \\
\text { l.e. } & 0 \\
\text { l.f. } & 1 \\
\text { l.g. } & 1 \\
\text { I.h. } & 0 \\
\end{array}$ & $\begin{array}{c}0 \\
0 \\
0 \\
0 \\
0 \\
7 \mathrm{E}-5 \\
3 \mathrm{E}-5 \\
\\
\\
1 \mathrm{E}-4 \\
\end{array}$ \\
\hline II. Large puddles & $\begin{array}{l}\text { a. Electrostatic sparks } \\
\text { b. Instrumentat ion faults } \\
\text { c. Welding and grinding sparks } \\
\text { d. Torch cutting } \\
\text { e. Camera and light power supply } \\
\text { shorts } \\
\text { f. Vehicle fuel fire } \\
\text { g. Lightning strikes } \\
\text { h. Core drill overheating }\end{array}$ & $\begin{array}{ll}\text { II.a. } & 0 \\
\text { II.b. } & 0 \\
\text { II.c. } & 0 \\
\text { II.d } & 0 \\
\text { II.e. } & 0 \\
\text { II.f. } & 1 \\
\text { II.g. } & 1 \\
\text { II.h. } & 0 \\
\end{array}$ & $\begin{array}{c}0 \\
0 \\
0 \\
0 \\
0 \\
7 E-5 \\
3 E-5 \\
0 \\
1 E-4 \\
\end{array}$ \\
\hline $\begin{array}{l}\text { III. Small } \\
\text { puddl es/channels }\end{array}$ & $\begin{array}{l}\text { a. Electrostatic sparks } \\
\text { b. Instrumentation faults } \\
\text { c. Welding and grinding sparks } \\
\text { d. Torch cutting } \\
\text { e. Camera and light power supply } \\
\text { shorts } \\
\text { f. Vehicle fuel fire } \\
\text { g. Lightning strikes } \\
\text { h. Core drill overheating }\end{array}$ & $\begin{array}{l}\text { III.a. } 0 \\
\text { III.b. } 0 \\
\text { III.c. } 0 \\
\text { III.d. } 0 \\
\text { III.e. } 0 \\
\text { III.f. } 1 \\
\text { III.g. } 1 \\
\text { III.h. } 0\end{array}$ & $\begin{array}{c}0 \\
0 \\
0 \\
0 \\
0 \\
7 E-5 \\
3 E-5 \\
0 \\
1 E-4\end{array}$ \\
\hline $\begin{array}{l}\text { Solvent - } \\
\text { permeated } \\
\text { studge }\end{array}$ & $\begin{array}{l}\text { a. Electrostatic sparks } \\
\text { b. Instrumentation faults } \\
\text { c. Welding and grinding sparks } \\
\text { d. Torch cutting } \\
\text { e. Camera and light power supply } \\
\text { shorts } \\
\text { f. Vehicle fuel fire } \\
\text { g. Lightning strikes } \\
\text { h. Core drill overheating }\end{array}$ & $\begin{array}{ll}\text { IV.a. } & 0 \\
\text { IV.b. } & 0 \\
\text { IV.e. } & 0 \\
\text { IV.d. } & 0 \\
\text { IV.e. } & 0 \\
\text { IV.f. } & 1 \\
\text { IV.g. } & 1 \\
\text { IV.h. } & 0\end{array}$ & $\begin{array}{c}0 \\
0 \\
0 \\
0 \\
\\
7 E-5 \\
3 E-5 \\
0 \\
1 E-4\end{array}$ \\
\hline $\begin{array}{l}\text { V. Solvent-permeated } \\
\text { saltcake }\end{array}$ & $\begin{array}{l}\text { a. Electrostatic sparks } \\
\text { b. Instrumentation faults } \\
\text { c. Welding and grinding sparks } \\
\text { d. Torch cutting } \\
\text { e. Camera and light power supply } \\
\text { shorts } \\
\text { f. Vehicle fuet fire } \\
\text { g. Lightning strikes } \\
\text { h. Core drill overheating }\end{array}$ & $\begin{array}{ll}\text { V.a. } & 0 \\
\text { V.b. } & 0 \\
\text { V.c. } & 0 \\
\text { V.d. } & 0.1 \\
\text { V.e. } & 0 \\
\text { V.f. } & 1 \\
\text { V.g. } & 1 \\
\text { V.h. } & 0.01\end{array}$ & $\begin{array}{c}0 \\
0 \\
0 \\
1 E-03 \\
0 \\
7 E-5 \\
3 E-5 \\
1 E-6 \\
1.1 E-3\end{array}$ \\
\hline
\end{tabular}

\subsubsection{In-Tank Instrumentation (Instrument Faults). Various in-tank instrumentation is used to monitor tank and waste conditions, including temperature measurement devices and waste level measurement devices. This instrumentation often includes low-power electrical circuits. In-tank instrumentation has been evaluated previously, including equipment failures, for the potential to ignite flammable gases and vapors in Scaief (1991).}


WHC-SD-WM-CN-032, REV. 0

The voltage/current conditions evaluated include normal operations and fault conditions. The frequency for fault conditions was not estimated. For this analysis, the frequency is not important but is assigned a conservatively high value of $1.0 \times 10^{-4} / \mathrm{yr}$. The voltages and currents that would be produced, even under fault conditions, is insufficient to ignite flammable vapors. As the solvent is well below the flashpoint (i.e., no flammable vapors even exist), it is incredible for in-tank instrumentation to heat the solvent and then ignite it. The probability of ignition is, therefore, assigned a value of zero.

3.4.2.3 Welding and Grinding. For the purposes of this safety analysis it is postulated that welding and grinding operations may be performed on the tank risers. Sparks and hot slag might fall to the waste surface. Welding operations are controlled. If welding is to be performed outside of a designated welding area, a hot work permit is required. For this analysis, it is assumed that an effort would be made to prevent sparks and hot slag from entering the tank, but due to human errors, they do. A frequency of $1.0 \mathrm{x}$ $10^{-2}$ per operation is assigned, therefore, to sparks or hot slag entering a tank. Welding and grinding is expected to be performed infrequently, certainly less than once per year per tank, therefore, the estimated annual frequency of sparks and slag reaching the waste surface is less than $1.0 \mathrm{x}$ $10^{-2}$ per tank per year but the conservatively high frequency will be assumed for this analysis.

The temperature of steel mechanical sparks is approximately $1400{ }^{\circ} \mathrm{C}$ (NFPA 321), but the available energy for ignition is small as the mass of the hot steel flakes is smal1. Based on testing described in Section 5.1.2 and 5.1 .4 , ignition is not produced by introducing hot steel particles $\left(1300^{\circ} \mathrm{C}\right.$, containing up to up to $270 \mathrm{~J}$ of available energy) into even small puddles of solvent or onto solvent saturated saltcake. For this analysis, the probability that welding sparks or hot slag will, therefore, ignite a solvent fire in a waste tank is assigned a value of zero.

3.4.2.4 Torch Cutting. Torch cutting differs from welding and grinding above, in that the use of a torch to cut large bolts, pipes, or other in-tank objects, offers the potential for a relatively large heated object to fall to the solvent pool or solvent entrained waste surface. A relatively large hot object may be able to vaporize solvent and still remain hot enough to ignite the vapors. Smaller objects tend to be cooled as their heat is used to vaporize the solvent.

The size and temperature of an object required to ignite various sized solvent pools or puddles has not been analyzed or tested in detail. The largest hot object tested in solvent ignition tests is a 3/16-inch diameter steel ball heated to $1,300{ }^{\circ} \mathrm{C}(270 \mathrm{~J}$ of available energy). Ignition did not occur with this largest hot object tested. Ignition by significantly larger hot objects than this, however, can not be ruled out at this time. Therefore, is assumed that a large hot object created during torch cutting could ignite some solvent situations. 
For this analysis, the following best estimate assumptions were made regarding ignition by torch cutting.

- The probability of igniting a floating pool is assumed to be zero as the hot object would fall through the floating organic layer and be cooled by the aqueous liquids below.

- The probability of igniting a large pool, a puddle, or a solvent filled channel is assumed to be zero. A series of tests has been performed for relatively narrow ( 1.3 to $1.5 \mathrm{~cm}$ ) channels (see WHCSD-WM-SARR-036, Appendix B). Such channels filled with dodecane could not be ignited with a small oxyacetylene torch. Wickstabilized flames started at one end of the channel failed to cause flame propagation up the channel. If sustained application of a torch flame will not ignite dodecane, it is judged that a piece of metal heated by a torch flame will not ignite the degraded solvent in the tank. Testing with radiant heaters determined that a channel filled with solvent could convect significant heat away from a heat source. A few tens of centimeters of channel length were adequate to dissipate more than $30 \mathrm{~kW} / \mathrm{m}^{2}$ of radiant heating applied to one end of a 1.3-cm-wide channel. Igniting the channel required that the heated solvent be confined by a barrier to prevent convective cooling. Even though small puddles and channels are easier to ignite than a large puddle or pool, a sizeable, sustained heat source is still required to cause ignition.

- The probability of igniting a solvent permeated sludge is assumed to be zero as testing indicated that even the sustained application of a flaming torch had difficulty igniting solvent/sludge mixtures.

- The probability of igniting a solvent permeated salt cake is judged to be high, as the heat transferred to the solvent can not be dissipated through the waste as easily and therefore, the hot object is more likely to remain above the ignition temperature as solvent is vaporized nearby. A probability of 0.1 is assigned.

3.4.2.5 Still Camera Photography and Video Camera Operations. The still camera system used is a standard $70-\mathrm{mm}$ still camera and flash unit mounted in a metal frame. The system is suspended in the tank by a flexible support hose containing wiring to the camera and flash unit. Power to the flash unit is supplied by a portable generator on the ground surface above the tank. The wiring is sealed but not intrinsically safe. The camera and flash unit are manualiy lowered into the tank to a level controlled by an adjustable safety stop ("top hat") at the top of the riser.

The video equipment consists of a standard video camera with pan and $t i 1 t$ capabilities and a quartz halogen light source. The in-tank portion of the video system operates on 12 volt DC. An auxiliary light source can be installed in a second riser to provide more illumination. The auxiliary light source uses a high pressure sodium bulb and operates on 120 volts alternating current. The light is enclosed in an impact resistant polycarbonate cover. The entire video camera unit is connected to a support stem. The camera system is supported by a shield plug that limits the length the system can intrude into the tank. 
Upset conditions include breaking a light and allowing the hot filament to fall to the waste surface and lowering the camera and light system to the waste surface with subsequent shorting of the electrical supply in or near the solvent. The potential for a hot filament to ignite the subcooled solvent is negligible as there is insufficient energy to heat solvent and then ignite it.

The frequency of shorting power cables in or near the solvent is estimated to be $0.001 /$ tank per year. This is a subjective estimate based on the following:

- Only a few in-tank photographic or video operations are anticipated to be performed in a tank

- A top hat (i.e., a shield plug that has a top flange larger in diameter than the riser inside diameter) is required to be used for photography and video imaging to be performed effectively and is therefore required by procedure. The top hat acts as a safety stop preventing the unit from being lowered to the waste surface

- The electrical wiring is unlikely to short even if immersed in the solvent or sludge, as it is sealed from the outside environment.

Shorting the power supply in or near the solvent could possibly dissipate electrical energy in the solvent if the wires were to remain in a pool or puddle for a period of time and not trip the over current protector. The energy dissipation (ohmic heating) in the solvent is expected to be low, however, as the solvent is not expected to be very electrically conductive and little current, if any would flow through the solvent. Conversely, if the wires were to enter sludge or saltcake, ohmic heating would be small due to the low resistivity of the aqueous brine contained in the waste. Electrical sparks that might be produced by two wires touching together are bounded by welding sparks and slag discussed above. It is concluded that shorting of the electrical power supply could not ignite pools, puddles, or solvent permeated sludges or saltcakes.

3.4.2.6 Vehicle Fuel Fires. A number of vehicles are used in the tank farms for construction, surveillance, sampling, and maintenance activities. Two incidents in the last several years have raised a concern about motor vehicles that enter the tank farms. An accident could occur that results in (1) vehicle fuel entering a waste storage tank and igniting or (2) fuel ignition followed by the burning fuel entering the tank.

In Lindberg (1995), it is assumed that there is one collision per year between a vehicle and a riser and there are 1560 entries per year to tank farms. Therefore there are 6.4 E-4 ruptures per tank farm entry per year $(1 / 1560)$. Since a collision alone isn't sufficient to start a fire, the following factors are also included: the probability of the riser breaking (5 $E-1)$, the probability of the vehicle fuel igniting $(1 E-2)$, the probability of the burning fuel going down the riser (1E-1), and the probability of the tank having organic solvent in it $(1.4 \mathrm{E}-1)$. Therefore the probability of having an organic solvent fire, given a collision, is:

$$
P(\text { organic fire })=(5 E-1)(1 E-2)(1 E-1)(1.4 E-1)=7 E-5
$$


In order to calculate a per tank number, a number of tanks that contain organic solvent had to be assumed. The assumption made is a straight line extrapolation of current data. That is, if 66 tanks screened resulted in 9 possible solvent tanks, 177 tanks screened will result in 24 possible solvent tanks. This is a simplistic assumption, however examining the history of solvent use at Hanford (see SARR-036) would indicate that less than 66 tanks contain solvent.

3.4.2.7 Lightning Strikes. The frequency of lightning strikes is based on information contained in Zach (1996).

The quantification of the energy delivered to the waste from lightning strikes has been evaluated in Cowley (1994) and with further clarification in a series of meetings and discussions with Dr. Martin Uman of the University of Florida. Lightning strikes that cause current to reach the waste have the potential to ignite solvent fires. This potential is evaluated below.

Frequency The likelihood of lightning striking a tank and contained equipment has been evaluated in Zach (1996). The probability of lightning being a pool fire initiator is the product of the frequency of lightning striking an object, the probability that the current will arc to the waste, the probability that the waste contains solvent where the arc hits and arc current subsequently flows, and the probability that the arc has sufficiently concentrated energy to ignite the solvent.

There are approximately .06 lightning flashes per square kilometer per year at Hanford. The surface area of a tank is approximately 5 E-4 square kilometers. A grounded metal object, such as a riser, will attract lightning that would strike anyway in an area whose radius is equal to the height of the metal object (Zach 1996). Since the height of risers above grade is in the one to three foot range, the risers by themselves are not high probability targets. The surface area of the tank is a more significant factor. The frequency of lightning hitting a tank is the product of the flash density times the surface are of the tank top:

$$
\begin{aligned}
& F(1 \text { ightning strike })=F(\text { lightning }) \times \text { Area of tank } \\
& F(1 \text { ightning strike })=6 E-2 \times 5 E-4=3 E-5 .
\end{aligned}
$$

The likelihood and amount of lightning current that will enter a waste tank differs significantly between SSTs and DSTs. This is because DSTS contain a closed steel liner and the risers are welded to this steel 1 iner. These factors make the buried DSTs effective Faraday cages (Cowley 1994). The structure of the SSTs, the rebar in the concrete, and the fact that the tank is buried, gives an SSTs some of the properties of a Faraday cage. SSTs, on the other hand, lack a closed steel liner, and this makes a SST less effective than a DST as a Faraday cage. In addition, construction drawings do not indicate that any effort was made during construction to make electrical connections between risers and the rebar in the concrete. There are, therefore, electrically noncontinuous paths through the tank that can result in arcing. 
Discussions with Dr. Martin Uman indicate that a lighting strike that "hits" the top of a tank could be expected to create high electrical potentials (voltages) between the risers and ground. These high voltages could cause lightning current to arc from the risers and installed equipment, into the waste and then to ground (through the tank side walls or bottom). As lightning strikes are often comprised of multiple strokes (stepped leader, return stroke, dart leader, return stroke, etc.), and each stroke can have multiple ground connections, it is quite possible that lightning current and arcing could occur through multiple paths (e.g., risers). As a conservative safety analysis assumption, the frequency of lightning current arcing to the waste surface in SSTs, is, therefore, assumed to be equal to the frequency that lightning strikes the top of the tank, or $3 E-5 / y r$ per SST.

Solvent Fire Ignition--The probability that arcing lightning current would cause ignition is evaluated below. The arc-producing scenario would occur when lightning current travels down equipment suspended above the waste surface (i.e., risers), and the current arcs from the end of the suspended object to the waste surface. The arc, or lightning current channel (the bright lighting bolt) is a very hot channel of air $\left(>20,000{ }^{\circ} \mathrm{K}\right)$ that has been turned into a plasma. The channel is fairly narrow (perhaps a centimeter in diameter) but causes significant heating of surrounding air. Radiative and convective heating of the waste surface (e.g. solvent pool) can be expected. In addition, in the arc-gap scenario, the energy deposition at the point of contact with the waste is concentrated. The energy deposition in the waste where the arc hits is estimated as follows (Cowley 1994):

First, right at the point of contact there is a very high density energy deposition. The energy deposition associated with arcing between gas and solid phases is different from ohmic heating. It is proportional to the time integral of the current rather than, as in ohmic heating, the integral of the square of the current. The electrical power generated as a function of time at a metal arc interface is roughly $V_{c} I(t)$ after the initial breakdown (which will provide energy to heat gas to tens of thousands of ${ }^{\circ} \mathrm{K}$ ), where $V_{c}$ is the contact potential difference between the metal and the arc, typicaliy 5 to 10 volts, and $I(t)$ is the time-varying current flow in the arc. The total energy generated is roughly $V_{c} Q$, where $Q$ is the total charge traversing the arc. The energy appears as heated gas and heated and melted electrode material. A typical lightning transfers 25 coulombs of charge and thus could liberate 250 joules of energy at the arc spot, in a volume of less than 1 cubic centimeter, perhaps less than a cubic millimeter. However, it is not likely that all of the lightning charge will flow across a single interior gap in a SST because of the many parallel paths available to the lightning current.

Once the current moves beyond the arc contact point a distance, the energy may be dissipated by ohmic heating. The energy deposition is described by:

$$
E=\frac{10^{4}}{S R O} \text { joules }
$$

where: $\quad s=$ conductivity of the waste.

Ro $=$ radius of arc spot, $m$. 
The electrical conductivity of the solvent has not been measured. The resistivity of organic liquids can be much higher than that of the waste aqueous liquids and solids. The resistivity of transformer oil and capacitor mineral oil is in the range of 1.0 to $100.0 \times 10^{10}$ ohm-m, with water contamination causing a reduction of about two orders of magnitude (Fink and Beatty 1976). Discharge of lightning current through a high resistivity fluid could cause significant heating. If the arc were to strike an organic pool, the high resistivity of the solvent could cause significant energy deposition (many MJs) in the pool. It would be difficult to conclude that such an arcgap scenario would not vaporize a significant amount of solvent and form and ignite a vapor cloud that is sufficiently large $(10-15 \mathrm{~cm}$ in diameter) to ignite a pool fire.

The probability that arcing lightning current will strike a solvent pool or puddle is not known as the presence, size, and location of solvent pools has not been determined; however, a review of tank waste photographs for interim stabilized tanks indicates that puddles (either solvent or more likely aqueous liquids) appear likely to form under risers. This may be due to equipment installation or flushing operations that cause depressions in the waste under the risers. For this analysis, it will be assumed that the equipment arc-gap configurations result from risers or equipment installed in a riser, and that the probability of a solvent puddle being formed in a waste depression under a riser, given the tank contains liquid pools and significant solvent, is one. The probability that a lightning strike to in-tank equipment would ignite a solvent fire is assigned a value based on the following.

- The probability that the resistance between the struck object and ground is high (assumed to be 1.0 unless field measurements indicate other wise, or the object is verified to be immersed in aqueous liquid which would be grounded through the tank bottom), times

- The probability that the equipment-to-waste arc path passes through a solvent pool or combustible solvent permeated saltcake. This is assumed to be 1.0 if the tank contains significant amounts of solvent, unless other data is available to indicate otherwise. times

- The probability that the lightning arc has sufficient energy and duration to ignite a solvent fire. This is assumed to 1.0 unless further analysis or testing indicates that solvent ignition by lightning strike is unlikely.

The probability of lightning initiated solvent fires, therefore, is conservatively assumed to be equal to the frequency of lightning strikes on tanks times the number of SSTs that contain significant amounts of solvent in a combustible configuration.

3.4.2.8 Core Drilling. The waste characterization effort uses core sampling as an important means for obtaining waste samples. Core sampling trucks provide the means to take a full-depth sample. Two core truck designs are available: one that operates in push mode only and one that can operate in 
WHC-SD-WM-CN-032, REV. 0

either push mode or rotary mode. In push mode, the core sample is taken using hydraulic pressure to push the samplers through the waste. This works well for soft waste materials. For hard waste materials, rotary-mode sampling is used.

Push-mode core sampling generates very little heat and is not considered to be a credible source for heating wastes and thus can not cause solvent fire ignition. In Keller (1991), the results of testing of the 5.7-cm-diameter core drill string to determine the effect of frictional heating on both the drill face surface and the waste simulant were reported. The testing was conducted in three simulants: a sludge, a soft saltcake, and a hard saltcake. The results from the test indicate that there was no temperature increase on the drill face surface from push-mode sampling the sludge material, there was a $6{ }^{\circ} \mathrm{C}$ increase in the soft saltcake, and there was a $22{ }^{\circ} \mathrm{C}$ increase in the hard saltcake. These tests are considered enveloping because they were done at higher insertion rates than can be accomplished in the field (i.e., rather than stopping every $48.3 \mathrm{~cm}$ to retrieve a sample, the testing pushed continuously as fast as possible). Based on these results it is concluded that push-mode core sampling has no potential to ignite organic solvent pools or solvent permeated waste sludges or saltcakes.

Rotary-mode core sampling, however, can generate significant heat from friction at the drill bit-waste interface. High temperatures have been experienced during testing with waste stimulants when drill bit progress through the stimulant is slow or stopped. In this situation, the heat generated is deposited in nearby waste for an extended period of time. When the bit is progressing through the waste as designed, the bit and waste remain relatively cool as the bit is continually moving down through and contacting cool waste.

To eliminate the possibility of heating waste to high temperatures, and thus the possibility of initiating waste combustion accidents (e.g., ferrocyanide-nitrate reactions and organic salt-nitrate reactions), the core drill system was modified to provide bit cooling by nitrogen purge and interlocks to shut down the system if key drilling parameters (bit down force and rotational speed) are exceeded.

A safety envelope was developed through testing and thermal analyses such that operation within the envelope (nitrogen purge on, bit down force below $5.2 \mathrm{kN}[11701 \mathrm{bf}]$, and rotational speed below 55 revolutions per minute) would maintain cool waste temperatures. Operation outside of the envelope is prevented by shutdown interlocks, which stop drilling operations. A fault tree analysis of the system estimated the frequency of the drill to operate (not shut down) following nitrogen purge failure to be less than $1.0 \times 10^{-6} / \mathrm{yr}$ for sampling operations that take 100 samples per year (Braun 1992). The frequency per tank-yr would be less. Operating experience during the first year of use, however, has already indicated that the system can be used in rotary mode without nitrogen purge running. Given this vulnerability, the $<1.0 \times 10^{-6} / \mathrm{yr}$ frequency needs to be used with caution and for this analysis it will be assumed that overheating conditions are credible. 
WHC-SD-WM-CN-032, REV. 0

The possibility of rotary core drill overheating to cause ignition of waste organic solvents has not been included in the rotary core sampling safety envelope development and testing program. It would seem unlikely that rotary core sampling could cause solvent ignition as the solvents would tend to vaporize as the waste surrounding the drill bit is heated. This vaporization would tend to cool the waste and also remove the solvent as a fuel. To demonstrate such behavior, which might allow drilling without nitrogen purge or shutdown interlocks, however, would appear to require rotary drill testing in solvent permeated waste simulants. The safety of drilling in solvent permeated waste, however, is assured by the safety envelope developed for fue1-nitrate hazards.

The safety envelope parameters ensure that the drill bit temperature will not increase more than $57^{\circ} \mathrm{C}$. This value is based on the drill bit reaching a maximum temperature of $150^{\circ} \mathrm{C}$ in the highest measured temperature tank waste. This temperature provides a safety margin below the autoignition temperature for waste solvents which is estimated to be over $200^{\circ} \mathrm{C}$ based on a review of hydrocarbon autoignition temperatures (AIT). This review indicated that the straight chain hydrocarbons, such as found in NPH, have some of the lowest AITs of the values reported for hydrocarbons. The minimum AITs for n-decane is reported at $210{ }^{\circ} \mathrm{C}$ and $230{ }^{\circ} \mathrm{C}$ for kerosine (Kuchta 1985). Tetradecane is reported to have a AIT of $202{ }^{\circ} \mathrm{C}$ (Lewis 1991).

High temperatures are produced when the drill bit has difficulty drilling through hard wastes. High temperatures would not be produced while drilling in surface pools or puddles, or within a few centimeters of the waste surface. Ignition of pools and puddles and solvent-filled channels or cracks by rotary drill core sampling is judged to not be credible. Therefore the probability of a drill overheating scenario to ignite solvent pools, puddles, or solvent-filled cracks or channels is assigned a value of zero.

Ignitability testing of sludges indicated that the sludge must contain a significant amount of solvent to support combustion. Such a sludge, however, would not contain any interstitial air. Over heating is not likely in a solvent saturated sludge as such a material is likely to be soft. Finally, burning with tank headspace air would not be possible if the ignition source is tens of centimeters below the waste surface. Ignition and sustained burning of solvent permeated sludges by rotary core drill sampling is judged to not be credible. The probability that core drill upsets could cause a solvent fire in sludges is, therefore, assigned a value of zero. The frequency of core drill overheating to cause a solvent fire in solvent permeated saltcake is conservatively estimated to be $1.0 \times 10^{-6} / \mathrm{yr}$ as follows.

- The frequency of the drill overheating is assumed to be $1.0 \times 10^{-4} / \mathrm{yr}$; this is a subjective estimate based on the fault tree analysis referenced above and the experience of being able to functionally over ride the shutdown interlock system.

- The probability that an overheating drill could cause solvent ignition is assigned a conservatively high probability of 0.01 based on the judgement that creating a flammable solvent vapor/air mixture in the waste solids near the drill bit and heating this mixture to the AIT is unlikely. This judgement is based on the belief that the heat generated by the drill bit will vaporize the solvent which will 
displace air that may be in the waste solids. It is judged likely that the vapors in the interstitial pores would exceed the upper flammability limit before the AIT was reached. Also, the vaporization of the solvent would cool the bit waste interface. Finally, high temperatures that are produced tens of centimeters below the waste surface would not cause a fire that could burn with headspace air. Ignition would need to occur at or near the waste surface. 
WHC-SD-WM-CN-032, REV. 0

\subsection{KEY ASSUMPTIONS}

Key assumptions used to define the fire sequences analyzed herein are summarized as follows.

\subsection{IGNITION AND FLAME SPREAD}

Ignition of a stable flame over a circular area of $0.3 \mathrm{~m}$ ( $1 \mathrm{ft}$.) diameter is postulated as the initial flame configuration. The flame is then postulated to spread at a radial velocity of $10 \mathrm{~cm} / \mathrm{s}$ until the entire pool area is covered by flame or until the fire is extinguished on low oxygen level.

\subsection{SOLVENT POOL AREA}

Two cases of pool area are considered to bracket possible pool sizes. First, a pool of $1 \mathrm{~m}^{2}$, termed herein a puddle, is postulated as a lower limit to be considered. $1 \mathrm{~m}^{2}$ is the pool area criterion used to screen tanks for the presence of solvent pools as detailed in Appendix B. Second, a large pool is postulated such that inflamed area is not limited by pool size. For SSTs and DSTs whose diameter is $22.9 \mathrm{~m}$ (75 ft.), a pool area of $210 \mathrm{~m}^{2}$ was used to quant ify the large pool case. For pools this size and larger, the fire was computed to extinguish on low oxygen level before the entire $210 \mathrm{~m}^{2}$ became inflamed. For DCRTs, the DCRT design that could contain the largest pool was selected (244-BX), and the pool was assumed to cover the entire waste surface $\left(34.1 \mathrm{~m}^{2}\right)$.

\subsection{FIRE EXTINGUISHMENT}

In all cases the fire was assumed to self-extinguish at an oxygen concentration of $13 \%$ by volume. This assumption is based on the results of large scale solvent pool fires in ventilated cells. It is recognized that solvent inventory could limit the quantity of solvent burned for the puddle fires, but fire extinguishment attributable to limited solvent inventory is neglected in this study.

\subsection{TANK PARAMETERS}

All cases were based on bounding (large) headspace volumes to maximize the oxygen inventory and thereby maximize the mass of solvent burned.

Vent paths were postulated at two extremes to cover possible cases. A minimal vent was postulated to evaluate maximum pressures that could be generated by a pool fire. For SSTs this minimal vent was based on the HEPA vent pipe. For DSTs and DCRTs, the minimal vent was zero, a conservative default value chosen because a reliable, realistic minimal vent path size was not known. A large vent path case was considered to evaluate maximum vacuum on cooldown. A circular opening, $1.27 \mathrm{~m}$ (50 in.) in diameter covered by a hinged plate was assumed to open at a pressure difference of 1 psi $(6.89 \mathrm{kPa})$. 
This flapper valve was hypothesized to simulate the venting through large risers (in tank pits) that are covered by caps held in place by gravity.

\subsection{TANK STRUCTURAL INTEGRITY}

All cases were analyzed on the basis that thermal and mechanical loads imposed on tank structures by the postulated pool fire did not cause changes in tank geometry or structural integrity.

\subsection{CARRYOVER OF AEROSOLS WITH VENTED GAS}

Contaminants made airborne by the fire were assumed to be transported as ideal gases. Headspace air was assumed to be perfectly mixed, and the fractional release of aerosols was computed on the basis of the fraction of gas vented from the tank. For passively ventilated tanks, atmospheric releases were assumed to end when the tank internal pressure fell below the pressure of the outside atmosphere. For actively ventilated tanks, it was assumed that continued operation of ventilation fans would purge all airborne contaminants from the tank. Mitigation of accident consequences by aerosol depletion was neglected in all cases. 


\subsection{KEY INPUT DATA}

Key inputs used to quantify consequences of postulated fires are listed as follows.

\subsection{RADIOLOGICAL DATA}

Key data used to compute radiological doses are listed in Table 5.1. Table 5.1 Radiological Input Data.

\begin{tabular}{|c|c|c|c|}
\hline Parameter & Units & $\begin{array}{l}\text { Numerical } \\
\text { Value }\end{array}$ & Reference \\
\hline atm. dispersion factor, onsite & $\mathrm{s} / \mathrm{m}^{3}$ & $3.41 \mathrm{E}-2$ & $\begin{array}{c}\text { Van Keuren } \\
(1996 a)\end{array}$ \\
\hline atm. dispersion factor, offsite & $\mathrm{s} / \mathrm{m}^{3}$ & $2.83 \mathrm{E}-5$ & $\begin{array}{c}\text { Van Keuren } \\
(1996 a)\end{array}$ \\
\hline breathing rate, onsite & $\mathrm{m}^{3} / \mathrm{s}$ & $3.3 \mathrm{E}-4$ & $\begin{array}{c}\text { Van Keuren } \\
(1996 a)\end{array}$ \\
\hline breathing rate, offsite & $\mathrm{m}^{3} / \mathrm{s}$ & $3.3 E-4$ & $\begin{array}{c}\text { Van Keuren } \\
\text { (1996a) }\end{array}$ \\
\hline ULD, Inhalation, SST solids & $\mathrm{Sv} / \mathrm{L}$ & $2.2 \mathrm{E} 5$ & Cowley (1996) \\
\hline ULD, Inhalation, SST liquids & $\mathrm{SV} / \mathrm{L}$ & $1.1 \mathrm{E} 4$ & Cowley (1996) \\
\hline ULD, Inhalation, DST liquids & SV $/ \mathrm{L}$ & $6.1 \mathrm{E3}$ & Cowley (1996) \\
\hline ULD, Inhalation, AWF liquids & $\mathrm{SV} / \mathrm{L}$ & $1.4 \mathrm{E} 3$ & Cowley (1996) \\
\hline ULD, Inhalation, Solvent liquid & $\mathrm{Sv} / \mathrm{kg}$ & 2.83 & Cowley (1996) \\
\hline ULD, Ingestion, SST solids & $\mathrm{Svm}^{3 / \mathrm{sL}}$ & 4.1 & Cowley (1996) \\
\hline ULD, Ingestion, SST liquids & $\mathrm{Svm}^{3 / \mathrm{SL}}$ & 0.052 & Cowley (1996) \\
\hline ULD, Ingestion, DST liquids & $\mathrm{Svm}^{3 /} \mathrm{sL}$ & 0.068 & Cowley (1996) \\
\hline ULD, Ingestion, AWF liquids & $\mathrm{Svm}^{3 /} \mathrm{sL}$ & 0.092 & Cowley (1996) \\
\hline $\begin{array}{l}\text { SST Solids Release, HEPA rupture, } \\
\text { passive SST }\end{array}$ & L & $1.27 \mathrm{E}-4$ & VanVleet (1996) \\
\hline $\begin{array}{l}\text { SST Solids Release, HEPA rupture, } \\
\text { active SST }\end{array}$ & L & $6.13 E-3$ & VanVleet (1996) \\
\hline $\begin{array}{l}\text { AWF Liquids Release, HEPA rupture, } \\
\text { DST }\end{array}$ & $\mathrm{L}$ & $5.62 E-3$ & VanVleet (1996) \\
\hline $\begin{array}{l}\text { SST Liquids Release, HEPA rupture, } \\
\text { DCRT }\end{array}$ & $\mathrm{L}$ & $3.57 \mathrm{E}-3$ & VanVleet (1996) \\
\hline
\end{tabular}




\subsection{TOXICOLOGICAL DATA}

Toxicological consequences were quantified in terms of a sum of fractions, where the fraction is the downwind concentration of each toxin divided by the limit for that toxin. The calculational method is described in Section 3.2, and the data needed to compute the fraction are 1isted in this Section.

\subsubsection{Headspace Gases}

Headspace gas concentrations and guideline concentrations used in this study, taken from Van Keuren (1996b), are summarized in Table 5.2.

Table 5.2 Headspace Gas Data.

\begin{tabular}{|l|l|c|c|c|c||}
\hline \hline \multicolumn{1}{|c|}{ Analyte } & \multicolumn{1}{|c|}{ Toxic Category } & $\begin{array}{c}\text { Headspace } \\
\text { Conc. } \mathrm{mg} / \mathrm{m}^{3}\end{array}$ & $\begin{array}{c}\text { EPRG-3 } \\
\mathrm{mg} / \mathrm{m}^{3}\end{array}$ & $\begin{array}{c}\text { EPRG-2 } \\
\mathrm{mg} / \mathrm{m}^{3}\end{array}$ & $\begin{array}{c}\text { EPRG-1 } \\
\mathrm{mg} / \mathrm{m}^{2}\end{array}$ \\
\hline benzene & central nervous system & 1.32 & 3130 & 1565 & 78 \\
\hline butanol & central nervous system & 164 & 7500 & 750 & 75 \\
\hline dociecane & central nervous system & 296 & 7330 & 1450 & 37 \\
\hline 2-hexanone & central nervous system & 2.68 & 5000 & 500 & 50 \\
\hline nitrous oxide & central nervous system & 1290 & 36,000 & 18,000 & 270 \\
\hline tridecane & central nervous system & 388 & 7330 & 1450 & 37 \\
\hline acetonitrile & systemic poison & 21.8 & 60 & 20 & 3 \\
\hline propane nitrile & systemic poison & 10.5 & 60 & 20 & 3 \\
\hline ammonia & corrosive and irritant & 199 & 680 & 140 & 17 \\
\hline 1,3 butadiene & corrosive and irritant & 0.19 & 11,000 & 110 & 22 \\
\hline methylene chloride & corrosive and irritant & 21.76 & 17,400 & 3480 & 700 \\
\hline tributyl phosphate & corrosive and irritant & 11.6 & 50 & 15 & 3 \\
\hline
\end{tabular}

The guideline limit for onsite workers was taken as ERPG-3 and the offsite limit was taken as ERPG-2. These limits are applicable to extremely unlikely accidents, in the frequency range of $10^{-4}$ to $10^{-6} / \mathrm{yr}$ (Van Keuren 1996b).

\subsubsection{Fire Reaction Products}

Guideline limits for reaction products, taken from Grigsby (1995), are summarized in Table 5.3 . 
WHC-SD-WM-CN-032, REV. 0

Table 5-3. Reaction Product Toxin Limits.

\begin{tabular}{|l|l|c|c|c||}
\hline \multicolumn{1}{|c|}{ Analyte } & \multicolumn{1}{|c|}{ Toxic Category } & $\begin{array}{c}\text { ERPG-3 } \\
\mathrm{mg} / \mathrm{m}^{3}\end{array}$ & $\begin{array}{c}\text { ERPG-2 } \\
\mathrm{mg} / \mathrm{m}^{3}\end{array}$ & $\begin{array}{c}\text { ERPG-1 } \\
\mathrm{mg} / \mathrm{m}^{3}\end{array}$ \\
\hline phosphorus pentoxide & corrosive and irritant & 100 & 25 & 5 \\
\hline nitrogen dioxide & corrosive and irritant & 94 & 47 & 3.8 \\
\hline carbon monoxide & systemic poison & 1360 & 690 & 230 \\
\hline
\end{tabular}

\subsubsection{Total Particulates}

Aerosol mass produced by the postulated solvent fire was computed as the sum of soot and $\mathrm{P}_{2} \mathrm{O}_{5}$. Soot production was evaluated as $20 \%$ of solvent burned, on the basis of data presented by Jordan and Linder (1983), $P_{2} 0_{5}$ mass

generated was computed as $4.32 \%$ of solvent burned as noted earlier in Section 3.3. Guideline limits for total particulate mass was taken as 500,50 and 30 $\mathrm{mg} / \mathrm{m}^{3}$ for ERPG-3, ERPG-2, and ERPG-1, respectively (Van Keuren 1996).

\subsubsection{HEPA Filter Rupture Toxins}

Toxicological consequences of HEPA filter rupture was computed on the basis of waste release volumes (Table 5.1 values), a release duration of $60 \mathrm{~s}$, and sum of fraction multipliers presented in tabular form by Van Keuren (1996b). The sum of fraction multipliers used herein are summarized in Table $5-4$.

Table 5-4. Sum of Fraction Multipliers.

\begin{tabular}{|c|c|c|c|c|c|}
\hline \multirow[t]{2}{*}{ Filter Type } & \multirow[t]{2}{*}{ Contaminant } & \multicolumn{4}{|c|}{ Sum of Fraction Multiplier, s/L } \\
\hline & & $\begin{array}{c}\text { Onsite, } \\
10^{-4}-10^{-6} \mathrm{yr}^{-1} \\
\end{array}$ & $\begin{array}{l}\text { offsite, } \\
10^{-4}-10^{-6} \mathrm{yr}^{-1} \\
\end{array}$ & $\begin{array}{c}\text { Onsite, } \\
10^{-2}-10^{-4} \mathrm{yr}^{-1}\end{array}$ & $\begin{array}{l}\text { Offsite, } \\
10^{-2}-10^{-4} y r^{-1}\end{array}$ \\
\hline SST-Passive & SST Solĩds & $1.0 \mathrm{E} 3$ & $1.7 \mathrm{E} 1$ & 2.9E4 & 3.3E1 \\
\hline SST-Active & SST Solids & $1.0 \mathrm{E} 3$ & $1.7 \mathrm{E} 1$ & 2.1E3 & 3.3E1 \\
\hline DST-Active & DST Liquids & 2.1E2 & $6.2 E-1$ & $7.5 \mathrm{E} 2$ & $8.4 \mathrm{EO}$ \\
\hline DCRT-Active & SST Liquids & $2.0 \mathrm{E} 2$ & $6.2 \mathrm{E}-1$ & $7.5 \mathrm{E} 2$ & $8.0 \mathrm{E} 0$ \\
\hline
\end{tabular}

An example calculation of the toxicological impact of HEPA rupture is presented in Section 3.2 
WHC-SD-WM-CN-032, REV. 0

\subsection{SPREADSHEET CALCULATIONS}

Seventeen solvent pool fire cases were evaluated in an effort to quantify unmitigated bounding consequences for SSTs, DSTs, and DCRTs. The analysis was performed with the aid of the EXCEL ${ }^{2}$ program. Calculations were carried out in three work sheets. The worksheets are described in detail as follows.

\subsection{WORKSHEET 1. FSAR SOLVENT POOL FIRE CASES}

This worksheet, hereafter referred to as WSI is reproduced on the following page. Each entry is described as follows.

Column A

Case numbers are assigned on an alphabetic lettering sequence. Case letters are carried over as the first column on each page of the workbook.

Column B

The type of waste tank considered for each case is identified.

$$
\begin{aligned}
\text { SST } & =\text { single shell tank } \\
\text { DST } & =\text { double shell tank } \\
\text { DCRT } & =\text { double contained receiver tank }
\end{aligned}
$$

Column $\mathrm{C}$

The size of pool analyzed is described for each case.

Column D

The pool surface area assumed for each case is listed.

Column $E$

The parameter (a consequence of a fire) that is maximized for the stated case is identified in column E. For example Cell E3 identifies "pressure" as the parameter. Highest pressure for the puddle fire (case A) results

\footnotetext{
${ }^{2}$ EXCEL is a registered trademark of Microsoft Corporation, Redmond, WA
} 
WS-1

FSAR Solvent Pool Fire Cases

\begin{tabular}{|c|c|c|c|c|c|c|c|c|c|c|c|c|c|c|c|c|c|}
\hline & A & $B$ & c & D & $E$ & $F$ & o & $\bar{H}$ & $I$ & J & $K$ & $L$ & $M$ & $\mathbf{N}$ & 0 & $P$ & $a$ \\
\hline 1 & Case & $\begin{array}{l}\text { Tank } \\
\text { Type } \\
\end{array}$ & $\begin{array}{c}\text { Solvent } \\
\text { Pool } \\
\text { Description }\end{array}$ & $\begin{array}{c}\text { Pool } \\
\text { Area } \\
m^{\prime \prime}\end{array}$ & \begin{tabular}{|c|} 
Bounding \\
Parameters
\end{tabular} & $\begin{array}{l}\text { Ventilation } \\
\text { Flow }\end{array}$ & $\begin{array}{c}\text { Vent } \\
\text { Description }\end{array}$ & $\begin{array}{l}\text { Poomre.4 } \\
\text { Peak } \\
\text { Prossure } \\
\text { psig (kPa) }\end{array}$ & \begin{tabular}{|} 
Pooline. \\
Peak \\
Vacuum \\
psig(kPa)
\end{tabular} & $\begin{array}{l}\text { Poolthre.4 } \\
\text { Solvent } \\
\text { Burned } \mathrm{kg}\end{array}$ & \begin{tabular}{|c|} 
Solvent \\
Aerosol \\
Relonse \\
Factor \\
ARF \\
\end{tabular} & $\begin{array}{c}\text { Poomre.4 } \\
\text { Leak Path } \\
\text { Factor } \\
\text { LPF }\end{array}$ & $\begin{array}{c}\text { Solvent } \\
\text { Atmosphere } \\
\text { Release } \\
\text { Basis } \\
\mathrm{kg} \\
\end{array}$ & $\begin{array}{c}\text { Aqueous } \\
\text { Bollon } \\
\mathrm{kg}\end{array}$ & \begin{tabular}{|c|} 
Aerosol \\
Releass \\
Factor for \\
Aqueous \\
ARF
\end{tabular} & $\begin{array}{c}\text { Aqueous } \\
\text { Atmospherte } \\
\text { Relense } \\
\mathrm{kg}\end{array}$ & $\begin{array}{l}\text { Aqueous } \\
\text { Unit Liter } \\
\text { Dose } \\
\text { Syn }\end{array}$ \\
\hline 2 & & & & & & & & & & & & & & & & & \\
\hline 3 & $a$ & SST & puddle & 1.0 & pressure & passive & hepa $a^{(1)}$ & $3.1(21.4)$ & $0.5(3.45)$ & 128 & 0.1 & 0.0747 & $9.56 \mathrm{E}-01$ & 161.28 & 0.002 & $2.41 E-02$ & $1.90 E+04$ \\
\hline 4 & $b$ & SST & puddle & 1.0 & vacuum & passive & $\begin{array}{c}\text { hopw } \\
\text { hlapper }\end{array}$ & $1.0(6.89)$ & $0.5(3.45)$ & 124 & 0.1 & 0.0399 & 4.95E-01 & 156.24 & 0.002 & $1.25 E-02$ & $1.10 E+04$ \\
\hline 6 & c. & SST & puddis & 1.0 & radiological & $\begin{array}{c}100 \mathrm{cfm} \\
\left(0.047 \mathrm{~m}^{2} / \mathrm{s}\right)\end{array}$ & hepe & $3.1(21.4)$ & $0.5(3.45)$ & 128 & 0.1 & 1.0 & $1.28 E+01$ & 161.28 & 0.002 & 3.23E-01 & $1.10 E+04$ \\
\hline 6 & d & ssr & puddito & 1.0 & toxicological & $\begin{array}{c}100 \mathrm{~cm} \\
\left(0.047 \mathrm{~m}^{3} / \mathrm{s}\right) \\
\end{array}$ & hepa & $3.1(21.4)$ & $0.5(3.45)$ & 128 & 0.1 & 1.0 & $1.28 E+01$ & 161.28 & 0.002 & 3.23E-01 & $1.10 E+04$ \\
\hline 7 & $\bullet$ & SST & large & 210 & pressure & passive & hepa & $29(200)$ & $0.1(0.69)$ & 148 & 0.03 & 0.146 & 6.39E-01 & 183.96 & 0.002 & $5.37 E-02$ & $1.10 E+04$ \\
\hline 8 & 1 & SST & large & 210 & vacuum & passive & $\begin{array}{l}\text { hepa/ } \\
\text { flapper }\end{array}$ & $1.8(12.4)$ & $6.8(46.9)$ & 84 & 0.03 & 0.3 & $7.56 \mathrm{E}-01$ & 105.84 & 0.002 & $6.35 \mathrm{E}-02$ & $1.10 E+04$ \\
\hline 9 & 0 & SST & large & 210 & radiological & $\begin{array}{c}100 \mathrm{ctm} \\
\left(0.047 \mathrm{~m}^{2} / \mathrm{s}\right)\end{array}$ & hopa & $29(200)$ & $0.1(0.69)$ & 146 & 0.03 & 1.0 & $4.38 E+\infty 0$ & 183.96 & 0.002 & 3.68E-01 & $1.10 E+04$ \\
\hline 10 & h & SST & large & 210 & toxicologicai & passive & $\begin{array}{l}\text { hepe/ } \\
\text { Alappor }\end{array}$ & $1.8(12.4)$ & $6.8(46.9)$ & 84 & 0.03 & 0.3 & $7.56 E-01$ & 105.84 & 0.002 & $6.35 E-02$ & $1.10 E+04$ \\
\hline 11 & 1. & DST & barge & 210 & pressure & sealed tank & none & $30.8(212)$ & $O(0)$ & 162 & 0.03 & 0.0 & $0.00 E+\infty$ & 204.12 & 0.002 & $0.00 E+\infty 0$ & 6.10E+03 \\
\hline 12 & 1 & DST & large & 210 & vacuum & passive & flapper & $2.1(14.5)$ & $8(55.2)$ & 92.5 & 0.03 & 0.31 & $8.60 E-01$ & 116.55 & 0.002 & $7.23 E-02$ & 6.10E+03 \\
\hline 13 & $k$ & DST & puddle & 1.0 & radiological & $\begin{array}{c}100 \mathrm{~cm} \\
\left(0.047 \mathrm{~m}^{2} / \mathrm{s}\right) \\
\end{array}$ & vent pipe ${ }^{(3)}$ & $0.9(6.21)$ & $0.1(0.69)$ & 132 & 0.1 & 1.0 & $1.32 E+01$ & 166.32 & 0.002 & 3.33E-01 & $6.10 E+03$ \\
\hline 14 & 1 & DST & large & 210 & toxicological & $\begin{array}{c}100 \mathrm{ctm} \\
\left(0.047 \mathrm{~m}^{2} / \mathrm{s}\right) \\
\end{array}$ & $\begin{array}{l}\text { Rapperl' } \\
\text { vent pipe }\end{array}$ & $2.0(13.8)$ & $5.2(35.9)$ & 92.1 & 0.03 & 1.0 & $2.76 E+00$ & 116.046 & 0.002 & 2.32E-01 & $6.10 E+03$ \\
\hline 15 & $m$ & DCRT & barge & 34.1 & pressure & sealod tank & none & $30.5(210)$ & $0(0)$ & 2.47 & 0.03 & 0.00 & $0.00 E+00$ & 3.1122 & 0.002 & $0.00 E+\infty$ & $1.10 E+04$ \\
\hline 16 & $n$ & DCRT & large & 34.1 & vacuum & passive & $\begin{array}{l}4(0.1 \mathrm{~m}) \\
\text { orifice }\end{array}$ & $18.3(126)$ & $1.2(8.27)$ & 2.12 & 0.03 & 0.31 & $1.97 E-02$ & 2.6712 & 0.002 & $1.66 \mathrm{E}-03$ & $1.10 E+04$ \\
\hline 17 & $\circ$ & DCRT & large & 34.1 & radiological & passive & $\begin{array}{l}40.1 \mathrm{~m}) \\
\text { orifice }\end{array}$ & $18.3(126)$ & $4.2(8.27$ & 2.12 & 0.03 & 0.31 & $1.97 E-02$ & 2.6712 & 0.002 & $1.66 \mathrm{E}-03$ & $1.10 E+04$ \\
\hline 18 & $p$ & DCRT & large & 34.1 & toxicological & passive & $\begin{array}{l}4 .(0.1 \mathrm{~m}) \\
\text { orifice }\end{array}$ & $18.3(126)$ & $1.2(8.27)$ & 2.12 & 0.03 & 0.31 & 1.97E-02 & 2.6712 & 0.002 & $1.66 \mathrm{E}-03$ & $1.10 E+04$ \\
\hline 19 & 9 & SST & entreined & 40.0 & radiological & $\begin{array}{c}100 \mathrm{~cm} \\
\left(0.047 \mathrm{~m}^{2} / \mathrm{s}\right)\end{array}$ & hepa $a^{(1)}$ & $4.4(30.5)$ & $0.7(4.8)$ & 130 & 0.1 & 1 & 1.30E+01 & 163.8 & 0.002 & $3.28 \mathrm{E}-01$ & $1.10 E+04$ \\
\hline 20 & 1 & SST & entrained & 40.0 & $\begin{array}{l}\text { toxicological } \\
\text { and vacuum }\end{array}$ & $\begin{array}{c}100 \mathrm{~cm} \\
\left(0.047 \mathrm{~m}^{\prime} / \mathrm{s}\right)\end{array}$ & $\begin{array}{l}\text { hopes } \\
\text { napper }\end{array}$ & $1.0(6.89)$ & 2.1 (14.5) & 113 & 0.1 & 1 & 1.13E+01 & 142.38 & 0.002 & 2.85E-01 & $1.10 E+04$ \\
\hline 21. & & \multirow{2}{*}{\multicolumn{6}{|c|}{$\begin{array}{l}\text { (1) HEPA Vent Modeled as } 3.75^{*}(9.5 \mathrm{~mm}) \text { orifice } \\
\text { (1) Flapper is } 50 \mathrm{in} .(1.27 \mathrm{~m}) \text { orifice opening at } 1 \text { psid }(6.89 \mathrm{kPa})\end{array}$}} & & & & & & & & & & \\
\hline 22 & & & & & & & & & & & & & & & & & \\
\hline 23 & & \multirow{2}{*}{\multicolumn{5}{|c|}{ (3) Vont Pipe on DST Modeled as 9.6 in. (0.24 m) orifice }} & & & & & & & & & & & \\
\hline 24 & & & & & & & & & & & & & & & & & \\
\hline
\end{tabular}


from the assumption of the minimal vent path (the HEPA vent) for this case. The parameter "vacuum" indicates that vent path configuration was selected to cause the highest possible tank vacuum following fire extinction and the cooldown of headspace gases. "Radiological" and "toxicological" descriptors indicate that the cases were designed to yield bounding radiological and toxicological consequences respectively.

Column $F$

The type of ventilation assumed for each case is described in Column $F$. "Passive" applies to SSTs and DCRTs where ventilation is caused by atmospheric breathing and natural convection. Ventilation flow for actively ventilated tanks is listed as "100 cfm $\left(0.047 \mathrm{~m}^{3} / \mathrm{s}\right)$ ". This flow rate designator is arbitrary and was used to remind the analyst that ventilation flow rates in actively ventilated tanks are of the order of $100 \mathrm{cfm}$ under normal conditions. This flow rate number is not used to determine fire consequences.

Column G

The type of vent path assumed for each case is listed in Column $G$. Footnotes (1), (2), and (3) quantify the size of the equivalent orifice used in POOLFIRE. 4 calculations.

Cases $i$ and $m$ are specified to have "none". Available information is insufficient to characterize the minimal vent opening for DSTs and DCRTs, so a default value of zero was assumed for these cases. Peak pressures computed for these cases is a conservative upper bound on pressures which could be generated by pool fires in these tanks.

Column $\mathrm{H}$

Peak pressure computed by POOLFIRE. 4 for each case is 1 isted in Column $\mathrm{H}$. As noted in Appendix A, POOLFIRE. 4 calculates specific burning rate as a function of oxygen concentration in headspace air. All cases analyzed herein use a bounding high value of $10 \mathrm{~cm} / \mathrm{s}$ for fire spread velocity.

\section{Column I}

Peak vacuum inside the tank, referenced to the outside atmosphere is Tisted for each case. Headspace air pressure is computed as a function of time by POOLFIRE.4, and the numbers 1 isted in column I are peak values from runs with POOLFIRE.4.

Column J

The mass of solvent burned from fire initiation to fire extinguishment at an oxygen level of 13 mole percent is listed for each case. These numbers come from runs with POOLFIRE.4. Note that cases with small vents result in the highest mass of solvent burned. The venting of oxygen from the tank leaves less oxygen in the tank to oxidize fuel; hence less fuel burns when larger vent paths are specified. 
Column $\mathrm{K}$

Aerosol release fraction, ARF, is listed for each case analyzed. Puddle fires use $A R F=0.1$ and large pool fires use $A R F=0.03$. Bases for these values are described in Section 3.3.

Column L

Leak path factor, defined as the fraction of reaction products released from the tank during the course of the pool fire, is listed for each case. The numbers iisted in this column for passive vent cases are values calculated by POOLFIRE.4. For actively ventilated tank a default value of unity is assumed, as is discussed in Section 3.3.

Column M

Solvent release from the tank to the environs is calculated from Eq. (38 ), assigning $C$ a default value of unity.

$$
S=M * 1 * A R F * L P F
$$

The EXCEL equation for Cell M3 is:

$$
M 3=J 3 * K 3 * L 3 .
$$

This equation is reproduced in all rows by advancing the row number appropriately. The release of contaminants in the solvent may be quantified by multiplying their concentrations by solvent mass releases calculated in Column $M$. This mass release is also the appropriate mass to be used for computing doses using ULD values as indicated in Eq. (3-1).

Column $N$

The mass of water evaporated is calculated as explained in Section 3.3.3;

$$
\text { aqueous mass }=\text { fuel burned * } 1.26
$$

The EXCEL equation, for Cell N3, is:

$$
N 3=1.26 * J 3
$$

Column 0

Aerosol release factor (ARF) for water evaporation is assigned a value of 0.002 for all cases. This ARF is cited as a bounding value for boiling Iiquids by Mishima (1994). 
WHC-SD-WM-CN-032, REV. 0

Column $P$

Atmospheric release of aqueous waste due to evaporation is calculated from Eq.(3-8) assigning $C$ a default value of unity:

$$
S=M * 1 * A R F * L P F \text {. }
$$

The EXCEL equation for Cell P3 is:

$$
P 3=N 3 * O 3 * L 3 .
$$

This equation is reproduced in all rows by advancing the row number appropriately.

Column $Q$

Unit liter doses for liquid waste, the waste subject to evaporative release, is listed for each case. The values stated in Column $Q$ are those given in Table 5.1.

\subsection{WORKSHEET 2. DOSE SUMMARY}

This worksheet, hereafter referred to as WS2 is reproduced on the following page. Each entry is described as follows.

Columns A Through $G$

These columns are repeated from WS1 to remind the analyst of case descriptions. 
WS-2

Dose Summary

\begin{tabular}{|c|c|c|c|c|c|c|c|c|c|c|c|c|}
\hline & A & $B$ & C & D & $\mathbf{E}$ & $\bar{F}$ & $\mathbf{G}$ & $\mathbf{H}$ & 1 & J & $\bar{K}$ & L \\
\hline$\frac{1}{2}$ & Case & Tank Type & $\begin{array}{c}\begin{array}{c}\text { Solvent } \\
\text { Pool } \\
\text { Description }\end{array} \\
\end{array}$ & $\begin{array}{c}\text { Pool Area } \\
\mathrm{m}^{2}\end{array}$ & $\begin{array}{c}\text { Bounding } \\
\text { Parameters }\end{array}$ & $\begin{array}{c}\begin{array}{c}\text { Ventilation } \\
\text { Flow }\end{array} \\
\end{array}$ & $\begin{array}{c}\text { Vent } \\
\text { Deseription }\end{array}$ & \begin{tabular}{|c|} 
On Sife \\
Solvent \\
Smoke \\
Dose, Sv \\
\end{tabular} & \begin{tabular}{|c|} 
Onsite \\
Aqueous \\
Boiloff \\
Dose, Sv \\
\end{tabular} & $\begin{array}{c}\text { HEPA } \\
\text { Rupture } \\
\text { Ddose } \\
\text { Onsite Sv } \\
\end{array}$ & $\begin{array}{c}\text { Total } \\
\text { Onsite } \\
\text { Dose Sv }\end{array}$ & $\begin{array}{c}\text { Total } \\
\text { Offsite } \\
\text { Dose SV } \\
\end{array}$ \\
\hline 2 & & & & & & & & & & & & \\
\hline 3 & $a$ & SST & puddle & 1.0 & pressure & passive & hepa ${ }^{(1)}$ & $3.04 E-05$ & $2.98 \mathrm{E}-03$ & $3.14 E-04$ & 3.33E-03 & $2.92 E-06$ \\
\hline 4 & $b$ & SST & puddle & 1.0 & vacuum & passive & flapper ${ }^{(2)}$ & $1.58 E-05$ & $1.54 \mathrm{E}-03$ & 3.14E-04 & 1.87E-03 & $1.64 \mathrm{E}-06$ \\
\hline 5 & c & SST & puddle & 1.0 & radiological & $\begin{array}{c}100 \mathrm{~cm} \\
\left(0.047 \mathrm{~m}^{2} / \mathrm{s}\right)\end{array}$ & hepa & $4.08 E-04$ & $3.99 \mathrm{E}-02$ & $1.52 E-02$ & $5.55 \mathrm{E}-02$ & 4.87E-05 \\
\hline 6 & d & SST & puddle & 1.0 & toxicological & $\begin{array}{c}100 \mathrm{cfm} \\
(0.047 \mathrm{~m} / \mathrm{s}) \\
\end{array}$ & hepa & $4.08 E-04$ & 3.99E-02 & $1.52 E-02$ & 5.55E-02 & 4.87E-05 \\
\hline 7 & $\cdot$ & SST & large & 210 & pressure & passive & hepa & $2.04 E-05$ & $6.65 E-03$ & $3.14 E-04$ & $6.98 \mathrm{E}-03$ & $6.12 \mathrm{E}-06$ \\
\hline 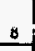 & $t$ & SST & large & 210 & vacuum & passive & $\begin{array}{l}\text { hepal } \\
\text { flapper }\end{array}$ & 2.41E-05 & $7.86 \mathrm{E}-03$ & 3.14E-04 & $8.20 \mathrm{E}-03$ & $7.19 E-06$ \\
\hline 9 & g. & SST & large & 210 & radiological & $\begin{array}{c}100 \mathrm{~cm} \\
\left(0.047 \mathrm{~m}^{2} / \mathrm{s}\right)\end{array}$ & hepa & 1.39E-04 & $4.55 \mathrm{E}-02$ & $1.52 \mathrm{E}-02$ & $6.09 \mathrm{E}-02$ & $5.34 E-05$ \\
\hline 10 & $h$ & SST & large & 210 & toxicological & passive & $\begin{array}{l}\text { hepal } \\
\text { fiapper }\end{array}$ & 2.41E-05 & $7.86 \mathrm{E}-03$ & 3.14E-04 & $8.20 E-03$ & $7.19 E-06$ \\
\hline 11 & $i$ & DST & large & 210 & pressure & sealed tank & none & $0.00 E+\infty$ & $0.00 E+\infty 0$ & $0.00 E+\infty 0$ & $0.00 E+\infty$ & $0.00 E+\infty$ \\
\hline 12 & $i$ & DST & large & 210 & vacuum & passive & flapper & $2.74 E-05$ & $4.96 \mathrm{E}-03$ & 8.90E-05 & $5.08 E-03$ & 4.35E-06 \\
\hline 13 & k & DST & puddle & 1.0 & radiological & $\begin{array}{c}100 \mathrm{~cm} \\
\left(0.047 \mathrm{~m}^{2} / \mathrm{s}\right)\end{array}$ & vent pipe ${ }^{(3)}$ & $4.20 \mathrm{E}-04$ & 2.28E-02 & $8.90 E-05$ & 2.33E-02 & 2.00E-05 \\
\hline 14 & 1 & DST & large & 210 & toxicological & $\begin{array}{c}100 \mathrm{~cm} \\
\left(0.047 \mathrm{~m}^{2} / \mathrm{s}\right)\end{array}$ & \begin{tabular}{|c|} 
flapper/ \\
vent pipe
\end{tabular} & $8.80 E-05$ & $1.59 E-02$ & 8.90E-05 & $1.61 E-02$ & $1.38 E-05$ \\
\hline 15 & $\mathrm{~m}$ & DCRT & largo & 34.1 & pressure & sealed tank & none & $0.00 E+\infty$ & $0.00 E+\infty$ & $0.00 \mathrm{E}+\infty$ & $0.00 E+00$ & $0.00 E+\infty 0$ \\
\hline 16 & $n$ & DCRT & large & 34.1 & vacuum & passive & $\begin{array}{c}4^{-1}(0.1 \mathrm{~m}) \\
\text { orifice }\end{array}$ & $6.28 E-07$ & $2.05 E-04$ & $4.40 \mathrm{E}-04$ & 6.46E-04 & $5.43 E-07$ \\
\hline 17 & 0 & DCRT & large & 34.1 & radiological & passive & $\begin{array}{c}4^{\prime \prime}(0.1 \mathrm{~m}) \\
\text { orifice }\end{array}$ & $6.28 \mathrm{E}-07$ & $2.05 \mathrm{E}-04$ & $4.40 E-04$ & $6.46 \mathrm{E}-04$ & 5.43E-07 \\
\hline 18 & $p$ & DCRT & large & 34.1 & toxicological & passive & $\begin{array}{c}4^{*}(0.1 \mathrm{~m}) \\
\text { orifice }\end{array}$ & $6.28 \mathrm{E}-07$ & $2.05 E-04$ & $4.40 E-04$ & $6.46 \mathrm{E}-04$ & $5.43 E-07$ \\
\hline 19 & 9 & SST & entrained & 40.0 & radiological & $\begin{array}{c}100 \mathrm{~cm} \\
(0.047 \mathrm{~m} / \mathrm{s})\end{array}$ & hepa $\mathrm{a}^{(1)}$ & 4.14E-04 & $4.05 \mathrm{E}-02$ & $1.52 \mathrm{E}-02$ & $5.62 \mathrm{E}-02$ & $4.92 \mathrm{E}-05$ \\
\hline 20 & $r$ & SST & entrained & 40.0 & $\begin{array}{l}\text { toxicological } \\
\text { and vacuum }\end{array}$ & $\begin{array}{c}100 \mathrm{~cm} \\
\left(0.047 \mathrm{~m}^{2} / \mathrm{s}\right)\end{array}$ & $\begin{array}{l}\text { hepal } \\
\text { flapper }\end{array}$ & $3.60 \mathrm{E}-04$ & $3.52 \mathrm{E}-02$ & $1.52 E-02$ & $5.08 \mathrm{E}-02$ & $4.45 E-05$ \\
\hline 22 & & \multirow{2}{*}{\multicolumn{5}{|c|}{$\begin{array}{l}\text { (1) HEPA Vent Modeled as } 3.75^{\circ}(9.5 \mathrm{~mm}) \text { orifice } \\
\text { (2) Flapper is } 50 \mathrm{in} \text {. }(1.27 \mathrm{~m}) \text { orifice opening at } 1 \mathrm{psid}(6.89 \mathrm{kPa})\end{array}$}} & & & & & & \\
\hline 23 & & & & & & & & & & & & \\
\hline 24 & & (3) Vent Pipe & on DST Mor & deled as 9.6 & $\sin (0.24 \mathrm{~m}) \mathrm{o}$ & vifice & & & & & & \\
\hline
\end{tabular}


Column $\mathrm{H}$

Onsite dose attributable to solvent smoke is calculated from Eq.(3-1).

The product of $\frac{\chi}{Q^{1}}$ and $R$ is entered as a constant:

$$
\frac{\chi}{Q^{1}} * R=0.0341 * 3.3 E-4=1.125 E-5
$$

The dose is calculated from:

$$
D(S V)=Q(L) * 1.125 E-5 * U L D(S V / L) .
$$

The EXCEL equation for Cell H3 is:

$$
H 3=M 3(\text { WS1 }) * 1.125 E-5 * 2.83
$$

The ULD for solvent is expressed in Sv/kg units (Table 5.1) so the $Q(L)$ is also expressed in $\mathrm{kg}$ (Column M of WSI).

Column I

Doses attributable to aqueous boiloff are computed from:

$$
D(S V)=Q(L) * 1.125 E-5 * U L D(S V / L) \text {. }
$$

$Q(L)$ and ULD(Sv/L) are calculated in WS1, so the EXCEL equation for Cell I3 is:

$$
I 3=P 3(\text { WS1 }) * Q 3(\text { WS1 }) * 1.125 E-5
$$

Column $\mathrm{J}$

The HEPA doses listed in Column $\mathrm{J}$ are inputs from hand calculations. The several cases are explained as follows. 
Onsite dose were computed for inhalation using Eq. (3-1). For passively ventilated SSTs, HEPA rupture is postulated to release $1.27 E-4 \mathrm{~L}$ of SST solids. The onsite dose is:

$$
D(S V)=1.27 E-4 * 3.41 E-2 * 3.3 E-4 * 2.2 E 5=3.14 E-4 S V
$$

A dose of 3.14E-4 SV is entered in Column $\mathrm{J}$ for all cases involving passively ventilated SSTs.

Similar calculations were done for the other cases, using releases quantified in Table 5.1.

Column $\mathrm{K}$

Total onsite dose is computed by summing doses due to solvent smoke, aqueous boiloff, and HEPA rupture. The EXCEL equation for Row 3 is:

$$
K 3=H_{3}+I_{3}+J_{3} .
$$

\section{Column L}

Offsite doses were calculated as the sum of inhalation and ingestion doses. Combining Equations (3-1), and (3-2), and (3-3) and performing algebraic manipulations, offsite dose can be expressed as:

$$
\text { total dose }=\text { inhalation dose } *\left(1+\frac{U L D_{G}}{R * U L D_{I}}\right)
$$

where total dose = inhalation dose + ingestion dose $U L D_{G}=$ unit liter ingestion dose, $5 \mathrm{v} \mathrm{m^{3 }} / \mathrm{sL}$, $R=$ breathing rate, $\mathrm{m}^{3} / \mathrm{s}$, $U_{L} D_{1}=$ unit liter inhalation dose, Sv/L.

Further, offsite inhalation dose can be expressed in terms of onsite inhalation dose and a ratio of atmospheric dispersion factors:

offsite inhalation dose $=$ onsite inhalation dose $* \frac{\frac{\chi}{Q^{1}} \text { offsite }}{\frac{\chi}{Q^{1}} \text { onsite }}$. 
The ratio of atmospheric dispersion factors is:

$$
\text { offsite/onsite }=2.83 E-5 / 3.41 E-2=8.30 E-4 \text {. }
$$

For SST solids, the ratio $U L D_{G} / R * U L_{1}$ is calculated on the basis of Table 5.1 data as:

$$
4.1 /(3.3 E-4 * 2.2 E 5)=0.0565 .
$$

The EXCEL equation for Cell L3 is:

$$
L 3=K 3 * 8.3 E-4(1+0.0565)
$$

The ratio $U L D_{G} / R * U L D_{1}$ is assigned a value of 0.0565 for all SST cases. For DSTs, the ratio is calculated to be 0.0338 using Table 5.1 data for DST liquids. DCRT releases are based on SST liquids, for which the $U \mathrm{UD}_{\mathrm{G}} / \mathrm{R} * \mathrm{ULD}_{\mathrm{I}}$ ratio is calculated to be 0.0143 .

\subsection{WORKSHEET 3. TOXICOLOGICAL}

This worksheet, hereafter referred to as WS3, is used to quantify the toxicological consequences of fires. Calculational steps are explained in detail as follows.

Columns $A$ through $G$

These columns are repeats from WSI and are provided to remind the analyst of particulars for each case being analyzed. 


\begin{tabular}{|c|c|c|c|c|c|c|c|c|c|c|c|c|c|c|c|c|}
\hline & A & $\mathbf{B}$ & $\mathbf{C}$ & D & $E$ & $F$ & $\mathbf{G}$ & $\mathrm{H}$ & 1 & $\mathrm{~J}$ & $\mathbf{K}$ & $\mathbf{L}$ & $M$ & $\mathbf{N}$ & 0 & $P$ \\
\hline 1 & Case & $\begin{array}{l}\text { Tank } \\
\text { Type }\end{array}$ & $\begin{array}{l}\text { Solvent Pool } \\
\text { Description }\end{array}$ & \begin{tabular}{|c|} 
Pool \\
Area $\mathrm{m}^{2}$ \\
\end{tabular} & $\begin{array}{l}\text { Bounding } \\
\text { Parameters }\end{array}$ & $\begin{array}{l}\text { Ventilation } \\
\text { Flow }\end{array}$ & $\begin{array}{c}\text { Vent } \\
\text { Description } \\
\end{array}$ & $\begin{array}{l}\text { Tank Gas } \\
\text { Volume } m^{2}\end{array}$ & $\begin{array}{c}\text { Poolfire. } 3 \\
\text { Maximum } \\
\text { Vent } \\
\text { duration } \\
.\end{array}$ & $\begin{array}{c}\text { Poollifire. } \\
\text { Solvent } \\
\text { Burned in } \\
\text { Vent } \\
\text { kg }\end{array}$ & $\begin{array}{c}\text { Poolfire.3 } \\
\text { Reaction } \\
\text { Gas } \\
\text { Fraction } \\
\end{array}$ & $\begin{array}{c}\text { Poolfire.3 } \\
\text { Headspace } \\
\text { Gas } \\
\text { Fraction }\end{array}$ & $\begin{array}{c}\text { Source } \\
\text { Conc. } \\
\mathrm{P}_{2} \mathrm{O}_{3} \\
\mathrm{mg} / \mathrm{m}^{3}\end{array}$ & $\begin{array}{c}\text { Source } \\
\text { Conc. } \\
\text { co } \\
\mathrm{mg} / \mathrm{m}^{3}\end{array}$ & $\begin{array}{c}\text { Source } \\
\text { Conc. } \mathrm{NO}_{2} \\
\mathrm{mg} / \mathrm{m}^{2} \\
\end{array}$ & $\begin{array}{c}\text { Aqueous } \\
\text { Vent Rate } \\
\text { Ls: }\end{array}$ \\
\hline 2 & & & & & & & & & & & & & & & & \\
\hline 3 & $a$ & SST & puddle & 1.0 & pressure & passive & hepa ${ }^{(i)}$ & $4.82 E+03$ & $2.50 \mathrm{E}+03$ & $8.73 E+01$ & $1.10 \mathrm{E}-01$ & 2.30E-01 & $3.75 \mathrm{E}+02$ & $3.67 E+02$ & $4.76 \mathrm{E}+01$ & 1.42E-05 \\
\hline 4 & b & SST & puddle & 1.0 & vacuum & passtve & $\begin{array}{c}\text { hepal } \\
\text { flapper }\end{array}$ & $4.82 E+03$ & $1.70 \mathrm{E}+03$ & $6.51 E+01$ & $7.56 \mathrm{E}-02$ & $2.40 E-01$ & $1.84 E+02$ & $1.60 \mathrm{E}+02$ & $2.34 E+01$ & 1.39E-05 \\
\hline 5 & c & SST & puddle & 1.0 & radiological & $\begin{array}{c}100 \mathrm{cim} \\
\left(0.047 \mathrm{~m}^{2} / \mathrm{s}\right) \\
\end{array}$ & hepa & $4.82 E+03$ & $2.50 E+03$ & $8.73 E+01$ & $1.10 E-01$ & 2.30E-01 & $3.75 \mathrm{E}+02$ & $3.67 E+02$ & 4.76E+01 & 1.42E-05 \\
\hline 6 & d & SST & puddle & 1.0 & toxicological & $\begin{array}{c}100 \mathrm{~cm} \\
\left(0.047 \mathrm{~m}^{3} / \mathrm{s}\right) \\
\end{array}$ & hepa & $4.82 \mathrm{E}+03$ & $2.50 E+03$ & $8.73 E+01$ & $1.10 \mathrm{E}-01$ & 2.30E-01 & $3.75 E+02$ & $3.67 E+02$ & $4.76 E+01$ & 1.42E-05 \\
\hline 7 & e & SST & large & 210 & pressure & passive & hepa & $4.82 \mathrm{E}+03$ & $1.30 E+03$ & $1.46 \mathrm{E}+02$ & $1.46 \mathrm{E}-01$ & $1.58 \mathrm{E}-01$ & $1.21 E+03$ & $1.19 E+03$ & $1.54 E+02$ & $4.13 \mathrm{E}-05$ \\
\hline 8 & $\mathbf{I}$ & SST & large & 210 & vacuum & passive & $\begin{array}{l}\text { hepal } \\
\text { tlapper }\end{array}$ & $4.82 \mathrm{E}+03$ & $6.70 \mathrm{E}+01$ & $8.40 E+01$ & $3.00 \mathrm{E}-01$ & $6.00 E-01$ & $3.77 E+02$ & $3.69 E+02$ & $4.78 E+01$ & 9.48E-04 \\
\hline 9 & g & sst & large & 210 & radiological & $\begin{array}{c}100 \mathrm{cfm} \\
\left(0.047 \mathrm{~m}^{1} / \mathrm{s}\right)\end{array}$ & hepa & $4.82 E+03$ & $1.30 \mathrm{E}+03$ & $1.46 \mathrm{E}+02$ & $1.46 \mathrm{E}-0 \mathrm{I}$ & $1.58 \mathrm{E}-01$ & $1.21 E+03$ & $1.19 E+03$ & $1.54 E+02$ & 4.13E-05 \\
\hline 10. & $\underline{h}$ & SST & large & 210 & toxicological & passive & $\begin{array}{l}\text { hepal } \\
\text { flapper }\end{array}$ & $4.82 E+03$ & $6.70 E+01$ & 6.40E+01 & $3,00 \mathrm{E}+01$ & $6.00 E-01$ & $3.77 \mathrm{E}+02$ & $3.69 E+02$ & $4.78 E+01$ & $9.48 E-04$ \\
\hline 11. & 1 & DST & targe & 210 & pressure & sealed tank & none & $5.30 \mathrm{E}+03$ & $8.30 E+01$ & $1.62 \mathrm{E}+02$ & $0.00 E+\infty$ & $0.00 \mathrm{E}+00$ & NA & NA & NA & $0.00 E+00$ \\
\hline 12 & 1 & DST & large & 210 & vacuum & passive & flapper & $5.30 E+03$ & $7,00 E+01$ & $9.25 \mathrm{E}+01$ & $3.10 \mathrm{E}-01$ & $6.10 E-0 t$ & $3.83 E+02$ & $3.75 E+02$ & $4.87 E+01$ & $1.03 E-03$ \\
\hline 13 & $k$ & DST & puddle & 1.0 & radiological & $\begin{array}{c}100 \mathrm{cfm} \\
\left(0,047 \mathrm{~m}^{2} / \mathrm{s}\right) \\
\end{array}$ & vent pipe e $^{(3)}$ & $5.30 \mathrm{E}+03$ & $1.20 \mathrm{E}+03$ & $5.00 E+01$ & $8,10 E-02$ & $2.50 E-01$ & $1.32 E+02$ & $1.29 E+02$ & $1.68 E+01$ & 2.25E-05 \\
\hline 14 & 1 & DST & large & 210 & toxicological & $\begin{array}{c}100 \mathrm{ctm} \\
\left(0.047 \mathrm{~m}^{1 / \mathrm{s}}\right)\end{array}$ & $\begin{array}{c}\text { Dappert } \\
\text { vent pipe }\end{array}$ & $5.30 \mathrm{E}+03$ & $7.00 E+01$ & $9.21 E+01$ & $3.10 E-01$ & $6.10 E-01$ & $3.82 E+02$ & $3.74 E+02$ & $4.85 E+01$ & $1.03 \mathrm{E}-03$ \\
\hline 15 & $\mathbf{m}$ & DCRT & large & 34.1 & pressture & sealed tank & none & $8.01 E+01$ & $1.95 \mathrm{E}+01$ & $2.47 \mathrm{E}+00$ & $0.00 E+00$ & $0.00 E+00$ & NA & NA & NA & $0.00 E+\infty$ \\
\hline 15 & $n$ & DCRT & large & 34.1 & vacuum & passive & $\begin{array}{c}4^{4}(0.1 \mathrm{~m}) \\
\text { orifce }\end{array}$ & $8.01 E+01$ & $3.30 \mathrm{E}+01$ & $2.12 \mathrm{E}+\infty$ & 3.10E-01 & $4.10 E-0 \mathrm{t}$ & $8.64 E+02$ & $8.47 E+02$ & $1.10 E+02$ & $5.02 E-05$ \\
\hline 17 & 0 & DCRT & large & 34.1 & radiological & passive & $\begin{array}{l}4 "(0.1 \mathrm{~m}) \\
\text { orifice }\end{array}$ & $8.01 E+01$ & $3.30 \mathrm{E}+01$ & $2.12 \mathrm{E}+00$ & $3.10 \mathrm{E}-01$ & $4.10 \mathrm{E}-01$ & $8.64 \mathrm{E}+02$ & $8.47 E+02$ & $1.10 \mathrm{E}+02$ & $5.02 E-05$ \\
\hline 18 & $p$ & DCRT & large & 34.1 & toxicological & passive & $\begin{array}{c}4^{n}(0.1 \mathrm{~m}) \\
\text { orifice }\end{array}$ & $8.01 \mathrm{E}+01$ & $3.30 \mathrm{E}+01$ & $2.12 \mathrm{E}+\infty 0$ & $3.10 \mathrm{E}-01$ & 4.10E-01 & $8.64 E+02$ & $8.47 E+02$ & $1.10 E+02$ & $5.02 \mathrm{E}-05$ \\
\hline 19 & 9 & SST & entrained & 40.0 & radiological & $\begin{array}{c}100 \mathrm{cmm} \\
\left(0.047 \mathrm{~m}^{\prime} / \mathrm{s}\right) \\
\end{array}$ & hepa $^{(1)}$ & $4.82 E+03$ & $1.70 \mathrm{E}+03$ & $1.30 E+02$ & 1.10E-01 & 2.10E-01 & $6.11 E+02$ & $5.99 E+02$ & $7.76 E+01$ & 2.12E-05 \\
\hline 20 & $r$ & SST & entrained & 40.0 & $\begin{array}{l}\text { toxicological } \\
\text { and vacuum }\end{array}$ & $\begin{array}{c}100 \mathrm{cim} \\
(0.047 \mathrm{~m} / \mathrm{s})\end{array}$ & $\begin{array}{l}\text { hepal } \\
\text { flapper }\end{array}$ & $4.82 E+03$ & $1.46 E+03$ & $1.13 \mathrm{E}+02$ & $1.00 \mathrm{E}-01$ & $3.10 \mathrm{E}-01$ & $3.27 \mathrm{E}+02$ & $3.20 \mathrm{E}+02$ & $4.15 \mathrm{E}+01$ & 1.95E-05 \\
\hline 21 & & & & & & & & & & & & & & & & \\
\hline 22 & & \multirow{2}{*}{\multicolumn{6}{|c|}{$\begin{array}{l}\text { (1) HEPA Vent Modeled as } 3.75^{4}(9.5 \mathrm{~mm}) \text { orifice } \\
\text { (2) Flapper is } 50 \mathrm{in} \text {. (1.27 m) orifice opening at } 1 \text { psid }(6.89 \mathrm{kPa})\end{array}$}} & & & & & & & & & \\
\hline 23 & & & & & & & & & & & & & & & & \\
\hline 24 & & \multicolumn{5}{|c|}{ (3) Vent Pipe on DST Modeled as 9.6 in. $(0.24 \mathrm{~m})$ orifice } & & & & & & & & & & \\
\hline
\end{tabular}




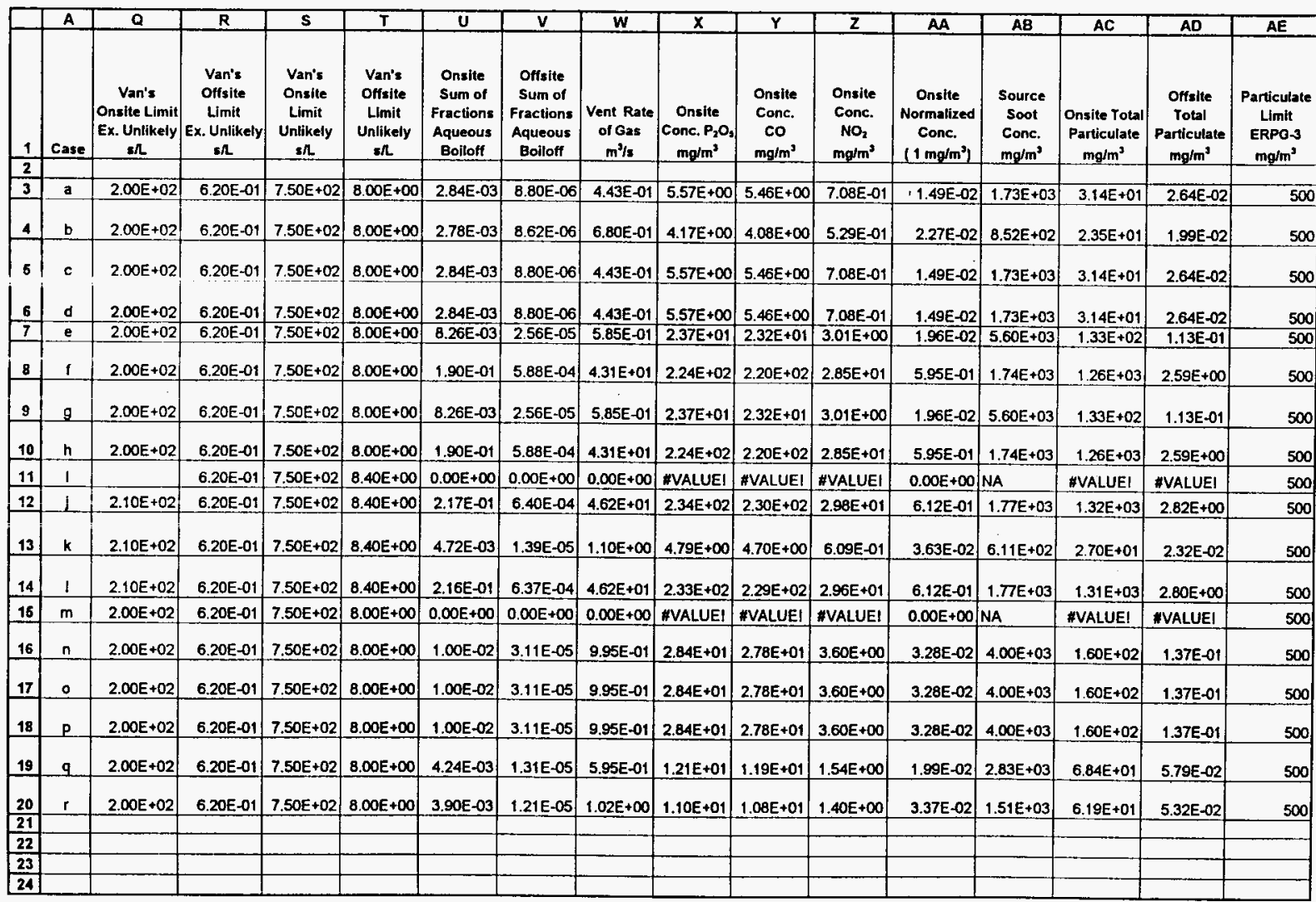


WS - 3

Toxicological

\begin{tabular}{|c|c|c|c|c|c|c|c|c|c|c|c|c|c|c|c|c|}
\hline & A & $\overline{A F}$ & $\mathbf{A G}$ & $\overline{A H}$ & AI & AJ & $\overline{A K}$ & $\overline{A L}$ & AM & $\overline{A N}$ & AO & AP & $A Q$ & AR & AS & AT \\
\hline$\frac{1}{2}$ & Case & $\begin{array}{c}\text { Particulate } \\
\text { Limit } \\
\text { ERPG-2 } \\
\text { mp/m' }\end{array}$ & $\begin{array}{c}\text { Particulate } \\
\text { Limit } \\
\text { ERPG-1 } \\
\text { mg/m } \\
\end{array}$ & \begin{tabular}{|c|} 
Ex. Un. \\
Onsite \\
Total \\
Particulate \\
Fraction \\
\end{tabular} & $\begin{array}{c}\text { Ex. Un. } \\
\text { Offsite } \\
\text { Total } \\
\text { Particulate } \\
\text { Fraction } \\
\end{array}$ & $\begin{array}{c}\text { Offsite } \\
\text { Normalized } \\
\text { Conc. } \\
\left(1 \mathrm{mg} / \mathrm{m}^{3}\right)\end{array}$ & $\begin{array}{c}\text { Ammonia } \\
\text { Headspace } \\
\text { Conc. } \\
\mathrm{mg} / \mathrm{m}^{3}\end{array}$ & $\begin{array}{c}\text { Ammonia } \\
\text { ERPG-3 } \\
\mathrm{mg} / \mathrm{m}^{2}\end{array}$ & $\begin{array}{c}\text { Ammonia } \\
\text { ERPG-2 } \\
\text { mglms }\end{array}$ & $\begin{array}{c}\text { Ammonia } \\
\text { ERPG-1 } \\
\mathrm{mg} / \mathrm{m}^{3}\end{array}$ & $\begin{array}{c}\text { 1,3 Buta } \\
\text { Heads pace } \\
\text { Conc. mg/m² }\end{array}$ & $\begin{array}{c}1,3 \text { Buta } \\
\text { ERPG } \\
\text { mg/m } \\
\end{array}$ & $\begin{array}{c}1,3 \text { Buta } \\
\text { ERPG.-2 } \\
\mathrm{mg} / \mathrm{m}^{3}\end{array}$ & $\begin{array}{c}1,3 \text { Buta } \\
\text { ERPG-1 } \\
\mathrm{mg} / \mathrm{m}^{3}\end{array}$ & $\begin{array}{l}\text { meth. chi. } \\
\text { Headspace } \\
\text { conc. mg/m }\end{array}$ & $\begin{array}{c}\text { meth. chl. } \\
\text { ERPG.3 } \\
\text { mg/m }\end{array}$ \\
\hline 3 & $a$ & 50 & 30 & $6.28 E-02$ & $5.29 \mathrm{E}-04$ & $1.25 \mathrm{E}-05$ & 199 & 680 & 140 & 17 & $0: 19$ & 11,000 & 110 & 22 & 21.76 & 17400 \\
\hline 4 & b & 50 & 30 & $4.69 \mathrm{E}-02$ & $3.98 E-04$ & $1.92 E-05$ & 199 & 680 & 140. & 17 & 0.19 & 11,000 & 110 & 22 & 21.76 & 17,400 \\
\hline 5 & $c$ & 50 & 30 & $6.28 \mathrm{E}-02$ & $5.29 \mathrm{E}-04$ & $1.25 \mathrm{E}-05$ & 199 & 680 & 140 & 17 & 0.19 & 11,000 & 110 & 22 & 21.76 & 17,400 \\
\hline$\frac{6}{7}$ & $d$ & $\begin{array}{l}50 \\
50\end{array}$ & 30 & $\frac{6.28 E-02}{267 E-02}$ & $\begin{array}{l}5.29 \mathrm{E}-04 \\
2.26 \mathrm{E}-03\end{array}$ & $1.25 E-05$ & 199 & 680 & 140 & 17 & 0.19 & 11,000 & 110 & 22 & 21.76 & 17,400 \\
\hline & & & & & & $1.66 \mathrm{E}-05$ & 199 & 680 & 140 & 17 & 0.19 & 11,000 & 110 & 22 & 21.76 & 17,400 \\
\hline 8 & 1 & 50 & 30 & $2.52 E+00$ & 5.17E-02 & $1.22 \mathrm{E}-03$ & 199 & 680 & 140 & 17 & 0.19 & $11,000$. & 110 & 22 & 21.76 & 17,400 \\
\hline 9 & $\theta$ & 50. & 30 & 2.67E-01 & $2.26 \mathrm{E}-03$ & $1.66 \mathrm{E}-05$ & 199 & 680 & 140 & 17 & 0.19 & 11,000 & 110 & 22 & 21.76 & 17,400 \\
\hline 10 & $\mathrm{~h}$ & 50 & 30 & $2.52 E+00$ & $5.17 E-02$ & $1.22 \mathrm{E}-03$ & 199 & 680 & 140 & 17 & 0.19 & 11.000 & 110 & 22 & 21.76 & 17,400 \\
\hline 11 & 1 & 50 & 30 & NA & NA & $0.00 E+00$ & 199 & 680 & 140 & 17 & 0.19 & 11,000 & 110 & 22 & 21.76 & $\$ 7,400$ \\
\hline 12 & $j$ & 50 & 30 & $2.64 E+\infty$ & $5.63 E-02$ & $1.31 \mathrm{E}-03$ & 199 & 680 & 140 & 17 & 0.19 & 11,000 & 110 & 22 & 21.76 & 17,400 \\
\hline 13 & $k$ & 50 & 30 & $5.39 \mathrm{E}-02$ & $4.65 E-04$ & $3.12 \mathrm{E}-05$ & 199 & 680 & 140 & 17 & 0.19 & 11,000 & 110 & 22. & 21.76 & 17,400 \\
\hline 14 & 1 & 50 & 30 & $2.63 E+\infty$ & $5.61 E-02$ & $1.31 E-03$ & 199 & 680 & 140 & 17 & 0.19 & 11,000 & 110 & 22 & 21.76 & 17,400 \\
\hline 15 & $\mathrm{~m}$ & 50 & 30 & NA & NA & $0.00 E+\infty$ & 199 & 680 & 140 & 17 & 0.19 & 11,000 & 110 & 22 & 21.76 & 17,400 \\
\hline ع & $\therefore$ & 50 & 30 & $3.19 E-01$ & $2.74 \mathrm{E}-03$ & $2.82 \mathrm{E}-05$ & 199 & 680 & 140 & 17 & 0.19 & 11,000 & 110 & 22 & 21.76 & 17,400 \\
\hline 17 & 0 & 50 & 30 & 3.19E-01 & 2.74E-03 & 2.82E-05 & 199 & 680 & 140 & 17 & 0.19 & 11,000 & 110 & 22 & 21.76 & 17,400 \\
\hline 18 & $p$ & 50 & 30 & 3.19E-01 & 2.74E-03 & 2.82E-05 & 199 & 680 & 140. & 17 & 0.19 & 11,000 & 110. & 22 & 21.76 & 17,400 \\
\hline 19 & 9 & 50 & 30 & 1.37E-01 & $1.93 \mathrm{E}-03$ & 1.68E-05 & 199 & 680 & 140 & 17 & 0.19 & 11,000 & 110 & 22 & 21.76 & 17,400 \\
\hline 20 & r & 50 & 30 & $1.24 \mathrm{E}-01$ & 1.77E-03 & $2.89 \mathrm{E}-05$ & 199 & 680 & 140 & 17 & 0.19 & 11,000 & 110 & 22 & 21.76 & 17,400 \\
\hline$\frac{21}{22}$ & & & & & & & & & & & & & & & & \\
\hline 23 & & & & & & & & & & & & & & & & \\
\hline 24 & & & & & & & & & & & & & & & & \\
\hline
\end{tabular}




\begin{tabular}{|c|c|c|c|c|c|c|c|c|c|c|c|c|c|c|c|c|}
\hline & A & $\overline{A U}$ & $\overline{A V}$ & AW & $A X$ & $\overline{A Y}$ & $A Z$ & BA & $\mathrm{BB}$ & $B C$ & $B D$ & $\mathrm{BE}$ & BF & $8 G$ & $\mathrm{BH}$ & 81 \\
\hline 1 & Case & $\begin{array}{c}\text { meth. chl. } \\
\text { ERPG-2 } \\
\mathrm{mg/m}\end{array}$ & $\begin{array}{c}\text { meth. chl. } \\
\text { ERPG-1 } \\
\text { mg/m? }\end{array}$ & $\begin{array}{c}\text { TBP } \\
\text { Headspace } \\
\text { Conc. } \\
\text { mo/m }\end{array}$ & $\begin{array}{c}\text { TBP } \\
\text { ERPG-3 } \\
\mathrm{mg} / \mathrm{m}^{\prime}\end{array}$ & $\begin{array}{c}\text { TBP } \\
\text { ERPG-2 } \\
m g / m^{3}\end{array}$ & $\begin{array}{c}\text { TBP } \\
\text { ERPG-1 } \\
\text { mg/m? }\end{array}$ & $\begin{array}{c}\mathrm{P}_{2} \mathrm{O}_{3} \\
\text { Headspace } \\
\text { Conc. } \mathrm{mg} / \mathrm{m}^{3}\end{array}$ & $\begin{array}{c}P_{2} \mathrm{O}_{3} \\
\text { ERPG-3. } \\
m g / m^{3}\end{array}$ & $\begin{array}{c}\mathrm{P}_{2} \mathrm{O}_{3} \\
\text { ERPG.2. } \\
\text { mgim! }\end{array}$ & $\begin{array}{c}P_{2} \mathrm{O}_{3} \\
\text { ERPO-1. } \\
\mathrm{mg} / \mathrm{m}^{3}\end{array}$ & $\begin{array}{c}\mathrm{NO}_{2} \\
\text { Heads pace } \\
\text { Conc. mg/m }\end{array}$ & $\begin{array}{c}\mathrm{NO}_{2} \\
\text { ERPG-3 } \\
\mathrm{mg} / \mathrm{m}^{3}\end{array}$ & $\begin{array}{c}\mathrm{NO}_{2} \\
\text { ERPO-2 } \\
\mathrm{mg} / \mathrm{m}^{3}\end{array}$ & $\begin{array}{c}\mathrm{NO}_{2} \\
\text { ERPO-1 } \\
\mathrm{mg} / \mathrm{m}^{3}\end{array}$ & $\begin{array}{c}\text { Acetonit. } \\
\text { Headspace } \\
\text { conc. } m g^{\prime} \mathrm{m}^{3}\end{array}$ \\
\hline \begin{tabular}{|l|}
2 \\
3
\end{tabular} & & 3480 & 700 & 116 & 50 & 15 & 3 & $375 \mathrm{E}+02$ & 100 & 25 & 5 & $476 \mathrm{E}+01$ & 94 & 47 & 3.8 & 2181 \\
\hline 4 & b & 3480 & 700 & 11.6 & 50 & 15 & 3 & $1.84 E+02$ & 100 & 25 & 5 & $2.34 E+01$ & 94 & 47 & 3.8 & 21.81 \\
\hline 5 & c & 3480 & 700 & 11.6 & 50 & 15 & 3 & $3.75 E+02$ & 100 & 25 & 5 & $4.76 E+01$ & 94 & 47 & 3.8 & 21.81 \\
\hline 6 & d & 3480 & 700 & 11.6 & 50 & 15 & 3 & $3.75 E+02$ & 100. & 25 & 5 & $4.76 E+01$ & 94 & 47 & 3.8 & 21.81 \\
\hline 7 & e & 3480 & 700 & 11.6 & 50 & 15 & 3 & $1.21 \mathrm{E}+03$ & 100 & 25 & 5 & $1.54 \mathrm{E}+02$ & 94 & 47 & 3.8 & 21.81 \\
\hline 8 & f & 3480 & 700 & 11.6 & 50 & 15 & 3 & $3.77 E+02$ & 100 & 25 & 5 & $4.78 E+01$ & 94 & 47 & 3.8 & 21.81 \\
\hline 19 & $g$ & 3480 & 700 & 11.6 & 50 & 15 & 3 & $1.21 E+03$ & 100 & 25 & 5 & $1.54 E+02$ & 94 & 47 & 3.8 & 21.81 \\
\hline 10 & $n$ & 3480 & 700 & 11.6 & 50 & 15 & 3 & $3.77 E+02$ & 100 & 25 & 5 & $4.78 E+01$ & 94 & 47 & 3.8 & 21.81 \\
\hline 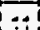 & $!$ & 3480 & 700 & 19.6 & 50 & 15 & 3 & $0.00 E+\infty$ & 100 & 25 & 5 & $0.00 E+\infty$ & 94 & 47 & 3.8 & 21.81 \\
\hline 12 & 1 & 3480 & 700 & 11.6 & 50 & 15 & 3 & $3.83 E+02$ & 100 & 25 & 5 & $4.87 E+01$ & 94 & 47 & 3.8 & 21.81 \\
\hline 13 & $k$ & 3480 & 700 & 11.6 & 50 & 15 & 3 & 1.32E +02 & 100 & 25 & 5 & $1.68 E+01$ & 94 & 47 & 3.8 & 21.81 \\
\hline 14 & 1 & 3480 & 700 & 11.6 & 50 & 15 & 3 & $3.82 E+02$ & 100 & 25 & 5 & $4.85 E+01$ & 94 & 47 & 3.8 & 21.81 \\
\hline 16 & $\mathrm{~m}$ & 3480 & 700 & 11.6 & 50 & 15 & 3 & $0.00 E+00$ & 100 & 25 & 5 & $0.00 E+00$ & 94 & 47 & 3.8 & 21.81 \\
\hline 16 & $n$ & 3480 & 700 & 11.6 & 50 & 15 & 3 & $8.64 E+02$ & 100 & 25 & 5 & 1.10E+02 & 94 & 47 & 3.8 & 21.81 \\
\hline 17 & 0 & 3480 & 700 & t1.6 & 50 & 15 & 3 & $8.64 E+02$ & 100 & 25 & 5 & $1.10 E+02$ & 94 & 47 & 3.8 & 21.81 \\
\hline 18 & $p$ & 3480 & 700 & 11.6 & 50 & 15 & 3 & $8.64 E+02$ & 100 & 25 & 5 & $1.10 E+02$ & 94 & 47 & 3.8 & 21.81 \\
\hline 19 & $g$ & 3480 & 700 & 11.6 & 50 & 15 & 3 & $6.11 E+02$ & 100 & 25 & 5 & $7.76 \mathrm{E}+01$ & 94 & 47 & 3.8 & 29.81 \\
\hline 20 & $r$ & 3480 & 700 & 11.6 & 50 & 15 & 3 & $3.27 E+02$ & 100 & 25 & 5 & $4.15 E+01$ & 94 & 47 & 3.8 & 21.81 \\
\hline 21 & & & & & & & & & & & & & & & & \\
\hline \begin{tabular}{|l|}
22 \\
\end{tabular} & & & & & & & & & & & & & & & & \\
\hline 23 & & & & & & & & & & & & & & & & \\
\hline 24 & & & & & & & & & & & & & & & & \\
\hline
\end{tabular}


WS -3

Toxicological

\begin{tabular}{|c|c|c|c|c|c|c|c|c|c|c|c|c|c|c|c|c|}
\hline & $A$ & B.J & BK & BL & BM & BN & BO & $\mathrm{BP}$ & Ba & BR & BS & BT & BU & BV & BW & $\mathrm{BX}$ \\
\hline 1 & Case & $\begin{array}{c}\text { Acetonit } \\
\text { ERPG } 3 \\
\mathrm{mg}^{3} \mathrm{~m}^{3}\end{array}$ & $\begin{array}{c}\text { Acetonit } \\
\text { ERPG-2 } \\
\mathrm{mg} / \mathrm{m}^{3}\end{array}$ & $\begin{array}{c}\text { Acetonit. } \\
\text { ERPG-1 } \\
m m^{\prime} \mathbf{m}^{3}\end{array}$ & $\begin{array}{c}\text { prop. nit. } \\
\text { Heads pace } \\
\text { conc. } \\
\text { mg/m }\end{array}$ & $\begin{array}{l}\text { prop. nit. } \\
\text { ERPG-3 } \\
\text { mg/m }^{3}\end{array}$ & $\begin{array}{c}\text { prop. nit. } \\
\text { ERPG.2 } \\
\mathrm{mg} / \mathrm{m}^{3}\end{array}$ & $\begin{array}{c}\text { prop. nit } \\
\text { ERPG-1 } \\
\mathrm{mg} / \mathrm{m}^{2}\end{array}$ & $\begin{array}{c}\text { co } \\
\text { Headspace } \\
\text { conc. } \\
\mathrm{mg} / \mathrm{m}^{3} \\
\end{array}$ & $\begin{array}{c}\text { CO } \\
\text { ERPG } 3 \\
\mathrm{mg}^{\prime} / \mathrm{m}^{2}\end{array}$ & $\begin{array}{c}\text { CO } \\
\text { ERPO-2 } \\
\mathrm{mg} / \mathrm{m}^{3}\end{array}$ & $\begin{array}{c}\text { CO } \\
\text { ERPG-1 } \\
\mathrm{mg} / \mathrm{m}^{3}\end{array}$ & $\begin{array}{c}\text { benezene } \\
\text { Headspace } \\
\text { conc. } \\
\mathrm{mg} / \mathrm{m}^{3}\end{array}$ & $\begin{array}{c}\text { benezene } \\
\text { ERPO-3 } \\
\mathrm{mg} / \mathrm{m}^{3}\end{array}$ & $\begin{array}{c}\text { benezene } \\
\text { ERPG-2 } \\
m g^{3} \mathrm{~m}^{3}\end{array}$ & $\begin{array}{c}\text { benezene } \\
\text { ERPG-1 } \\
\mathrm{mg} / \mathrm{m}^{3}\end{array}$ \\
\hline 2 & & & & & & & & & & & & & & & & \\
\hline 3 & a & 60 & 20 & 3 & 10.47 & 60 & 20 & 3 & $3.67 \mathrm{E}+02$ & 1360 & 690 & 230 & 1.32 & 3130 & 1565 & 78 \\
\hline 4 & b & 60 & 20 & 3 & 10.47 & 60 & 20 & 3 & $1.80 \mathrm{E}+02$ & 1360. & 690 & 230 & 1.32 & 3130 & 1565 & 78 \\
\hline 6 & c & 60 & 20 & 3 & 10.47 & 60 & 20 & 3 & $3.67 \mathrm{E}+02$ & 1360 & 690 & 230 & 1.32 & 3130 & 1565 & 78 \\
\hline 5 & d & 60 & 20 & 3 & 10.47 & 60 & 20 & 3. & $3.67 E+02$ & 1360 & 690 & 230 & 1.32 & 3130 & 1565 & 78 \\
\hline 7 & e & 60 & 20 & 3 & 10.47 & 60 & 20 & 3 & $1.19 E+03$ & 1360 & 690 & 230 & 1.32 & 3130 & 1565 & 78 \\
\hline 8 & $f$ & 60 & 20 & 3. & 10.47 & 60 & 20 & 3. & $3.69 \mathrm{E}+02$ & 1360 & 690 & 230 & 1.32 & 3130 & 1565 & 78 \\
\hline 9 & $g$ & 60 & 20 & 3 & 10.47 & 60 & 20 & 3 & 1.19E+03 & 1360 & 690 & 230. & 1.32 & 3130 & 1565 & 78 \\
\hline 10 & h & 60 & 20 & 3 & 10.47 & 60 & 20 & 3 & $3.69 E+02$ & 1360 & 690 & 230 & 1.32 & 3130 & 1565 & 78 \\
\hline 11 & 1 & 60 & 20 & 3 & 10.47 & 60 & 20 & 3. & $0.00 E+\infty$ & 1360 & 690 & 230 & 1.32 & 3130 & 1565 & 78 \\
\hline 12 & 1 & 60 & 20 & 3 & 10.47 & 60 & 20 & 3 & $3.75 E+02$ & 1360 & 690 & 230 & 1.32 & 3130 & 1565 & 78 \\
\hline 13 & $k$ & 60 & 20 & 3 & 10.47 & 60 & 20 & 3 & $1.29 E+02$ & 1360 & 690 & 230 & 1.32 & 3130 & 1565 & 78 \\
\hline 14 & 1 & 60 & 20 & 3 & 10.47 & 60 & 20 & 3 & $3.74 E+02$ & 1360 & 690 & 230 & 1.32 & 3130 & 1565 & 78 \\
\hline \pm 5 & $i i i$ & 60 & 20 & 3 & 10.47 & 60 & 20. & 3 & $0.00 E+\infty 0$ & 1360 & 690 & 230 & 1.32 & 3130 & 1565 & 78 \\
\hline 16 & $n$ & 60 & 20 & 3 & 10.47 & 60 & 20 & 3 & $8.47 E+02$ & 1360 & 690 & 230 & 1.32 & 3130 & 1565 & 78 \\
\hline 17 & $n$ & 60 & 20 & 3. & 10.47 & 60 & 20 & 3 & $8.47 E+02$ & 1360 & 690 & 230 & 1.32 & 3130 & 1565 & 78 \\
\hline 18 & P & 60 & 20 & 3 & 10.47 & 60 & 20 & 3 & $8.47 E+02$ & 1360 & 690 & 230 & 1.32 & 3130 & $\begin{array}{r}1565 \\
\end{array}$ & 78 \\
\hline 19 & 9 & 60 & 20 & 3 & 10.47 & 60 & 20 & 3 & $5.99 \mathrm{E} * 02$ & 1360 & 690 & 230 & 1.32 & 3130 & 1565. & 78 \\
\hline 20 & $r$ & 60 & 20 & 3 & 10.47 & 60 & 20 & 3. & $3.20 \mathrm{E}+02$ & 1360 & 690 & 230 & 1.32 & 3130 & 1565 & 78 \\
\hline 22 & & & & & & & & & & & & & & & & \\
\hline 23 & & & & & & & & & & & & & & & & \\
\hline 24 & & & & & & & & & & & & & & & & \\
\hline
\end{tabular}


WS-3

Toxicologica|

\begin{tabular}{|c|c|c|c|c|c|c|c|c|c|c|c|c|c|c|c|c|}
\hline & A & BY & BZ & $\mathrm{CA}$ & CB & $\mathrm{CC}$ & CD & $\mathrm{CE}$ & CF & CG & $\mathrm{CH}$ & $\mathrm{Cl}$ & CJ & CK & $\mathrm{CL}$ & $\mathrm{CM}$ \\
\hline$\frac{1}{3}$ & Case & $\begin{array}{c}\begin{array}{c}\text { butanol } \\
\text { Headspace } \\
\text { conc. } \\
\text { mg/m }\end{array} \\
\end{array}$ & $\begin{array}{c}\text { butanol } \\
\text { ERPG } 3 \\
\mathrm{mg} / \mathrm{m}^{2}\end{array}$ & $\begin{array}{c}\text { butanol } \\
\text { ERPG-2 } \\
\mathrm{mq} / \mathrm{m}^{3}\end{array}$ & $\begin{array}{c}\text { butanol } \\
\text { ERPG-1 } \\
\mathrm{my} / \mathrm{m}^{3}\end{array}$ & $\begin{array}{c}\text { dodecane } \\
\text { Headspace } \\
\text { conc. } \\
m g / m^{3}\end{array}$ & $\begin{array}{c}\text { dodecane } \\
\text { ERPG } \\
m g^{\prime} m^{3} \\
\end{array}$ & $\begin{array}{c}\text { dodecane } \\
\text { ERPG-2 } \\
\text { mq/mi }\end{array}$ & $\begin{array}{c}\text { dodecane } \\
\text { ERPG.1 } \\
\mathrm{mp} / \mathrm{m}^{3}\end{array}$ & $\begin{array}{c}\text { 2thexano } \\
\text { Headspace } \\
\text { conc. } \\
m g / m^{3}\end{array}$ & $\begin{array}{c}\text { 2-hexano } \\
\text { ERPO-3 } \\
\text { mg/mi }\end{array}$ & $\begin{array}{c}\text { 2-hexano } \\
\text { ERPG-2 } \\
m g / m^{3}\end{array}$ & $\begin{array}{c}\text { 2-hexano } \\
\text { ERPG-1 } \\
\mathrm{mg} / \mathrm{m}^{3}\end{array}$ & $\begin{array}{c}\mathrm{N}_{2} \mathrm{O} \\
\text { Heads pace } \\
\text { conc. } \\
\mathrm{mg} / \mathrm{m}^{\mathbf{3}} \\
\end{array}$ & $\begin{array}{c}\mathrm{N}_{2} \mathrm{O} \\
\text { ERPG-3 } \\
\mathrm{mg} / \mathrm{m}^{3}\end{array}$ & $\begin{array}{c}\mathrm{N}_{2} \mathrm{O} \\
\text { ERPG-2 } \\
\mathrm{mg} / \mathrm{m}^{2}\end{array}$ \\
\hline 2 & & & & & & & & & & & & & & & & \\
\hline 3 & a & 164.13 & 7500 & 750 & 75 & 296 & 7330 & 1450 & 37 & 2.68 & 5000 & 500 & 50 & 1290 & 36000 & 18000 \\
\hline 4 & b & 164.13 & 7500 & 750 & 75 & 296 & 7330 & 1450 & 37 & 2.68 & 5000 & 500 & 50 & 1290 & 36000. & 18000 \\
\hline 0 & c & 164.13 & 7500 & 750 & 75 & 296 & 7330 & 1450 & 37 & 2.68 & 5000 & 500 & 50 & 1290 & 36000 & 18000 \\
\hline 6 & d & 164.13 & 7500 & 750 & 75 & 296 & 7330 & 1450 & 37 & 2.68 & 5000 & 500 & 50 & 1290 & 36000 & 18000 \\
\hline 7 & e & 164.13 & 7500 & 750 & 75 & 296 & 7330 & 1450 & 37 & 2.68 & 5000 & 500 & 50 & 1290 & 36000 & 18000 \\
\hline$B$ & 1 & $\{64.1\}$ & 7500 & 750 & 75 & 296 & 7330 & 1450 & 37 & 2,68 & 5000 & 500 & 50 & 1290 & 36000 & 18000 \\
\hline 9 & n & 164.13 & 7500 & 750 & 75 & 296 & 7330 & 1450 & 37. & 2.68 & 5000 & 500 & 50 & 1290 & 36000 & 18000 \\
\hline 10 & $n$ & 164.13 & 7500 & 750. & 75 & 296 & 7330 & 1450 & 37 & 2.68 & 5000 & 500 & 50 & 1290 & 36000 & 18000 \\
\hline 4 & $:$ & 164.13 & 7500 & 750 & 75 & 296 & 7330 & 1450 & 37. & 2.68 & 5000 & 500 & 50 & 1290 & 36000 & 18000 \\
\hline 12 & 1 & 164.13 & 7500 & 750 & 75 & 296 & 7330 & 1450 & 37 & 2.68 & 5000 & 500 & 50 & 1290 & 36000 & 18000 \\
\hline 13 & n & 164.13 & 7500 & 750 & 75 & 296 & 7330 & 1450 & 37 & 2.68 & 5000 & 500 & 50 & 1290 & 36000 & 18000 \\
\hline 14 & 1 & 164.13 & 7500 & 750 & 75 & 296 & 7330 & 1450 & 37 & 2.68 & 5000 & 500 & 50 & 1290 & 36000 & 18000 \\
\hline 15 & $\mathrm{~m}$ & 164.13 & 7500 & 750 & 75 & 296 & 7330 & 1450 & 37 & 2.68 & 5000 & 500 & 50 & 1290 & 36000 & 18000 \\
\hline 16 & $n$ & 164.13 & 7500 & 750 & 75 & 296. & 7330 & 1450 & 37 & 2.68 & 5000 & 500 & 50 & 1290 & 36000 & 18000 \\
\hline 17 & 0 & 164.13 & 7500 & 750 & 75 & 296 & 7330 & 1450 & 37 & 2.68 & 5000 & 500 & 50 & 1290 & 36000 & 18000 \\
\hline 18 & $p$ & 164.13 & 7500 & 750 & 75 & 296 & 73330 & 1450 & 37 & 2.68 & 5000 & 500 & 50 & 1290 & 36000 & 18000 \\
\hline 19 & g. & 164.13 & 7500 & 750 & 75 & 296 & 7330 & 1450 & 37 & 2.68 & 5000 & 500 & 50 & 1290 & 36000 & 18000 \\
\hline 20 & $r$ & 164.13 & 7500 & 750 & 75 & 296 & 7330 & 1450 & 37 & 2.68 & 5000 & 500 & 50 & 1290 & 36000 & 18000 \\
\hline$\frac{21}{22}$ & & & & & & & & & & & & & & & & \\
\hline 23 & & & & & & & & & & & & & & & & \\
\hline 24 & & & & & & & & & & & & & & & & \\
\hline
\end{tabular}


WS-3

Toxicological

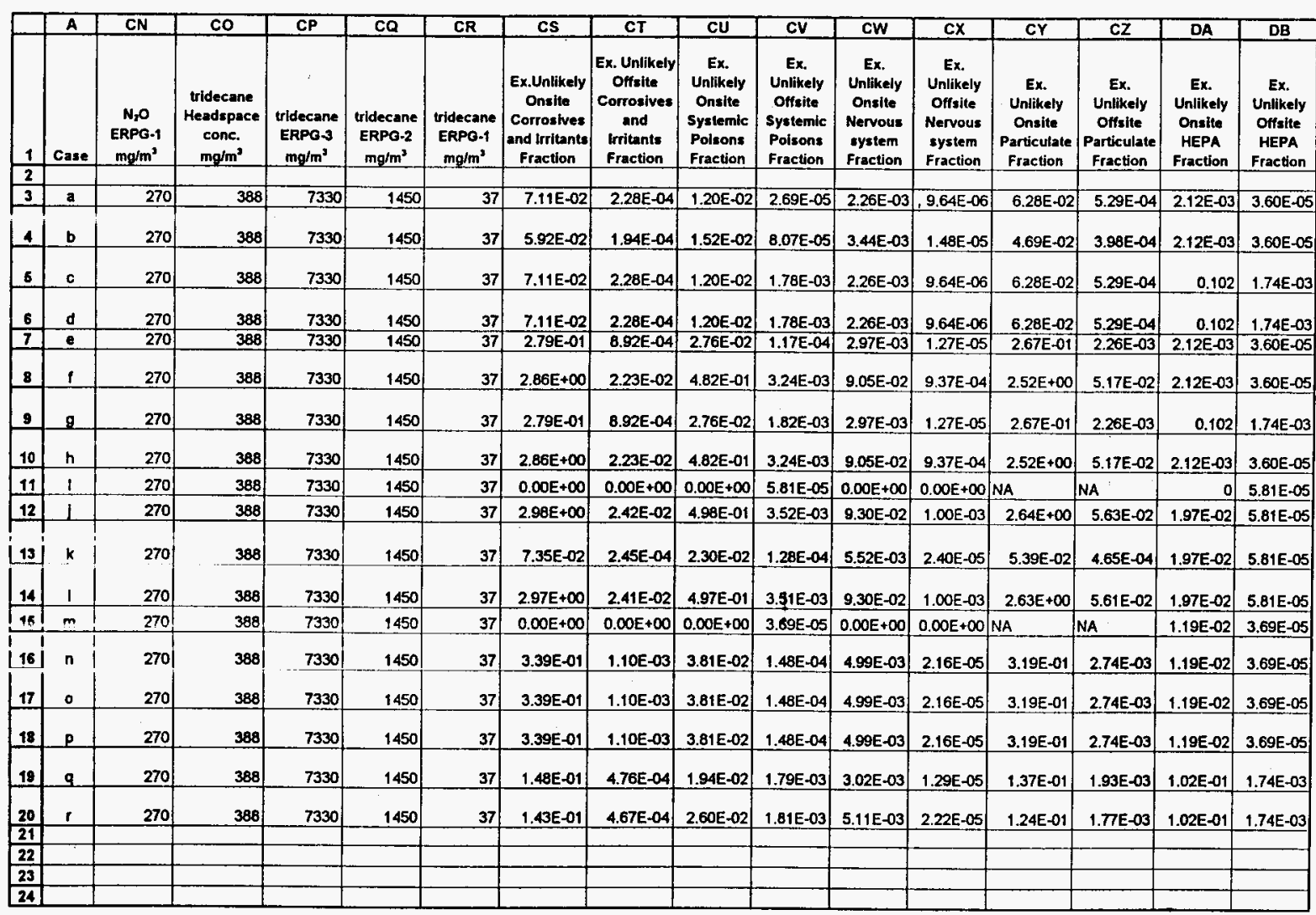




\begin{tabular}{|c|c|c|c|c|c|c|c|c|c|}
\hline & A & $D C$ & $\mathrm{DD}$ & $\overline{D E}$ & DF & $\overline{D G}$ & $\mathrm{DH}$ & Dif & $\overline{D J}$ \\
\hline 1 & Case & \begin{tabular}{|c|} 
Unlikely \\
Onsite \\
HEPA \\
Fraction \\
\end{tabular} & $\begin{array}{c}\text { Unlikely } \\
\text { Offaite } \\
\text { HEPA } \\
\text { Fraction } \\
\end{array}$ & \begin{tabular}{|c|} 
Ex. Un. \\
Onsite \\
Sum of \\
Fractions \\
Aqueous \\
Bolloff \\
\end{tabular} & $\begin{array}{c}\text { Ex. Un. } \\
\text { Offsite } \\
\text { Sum of } \\
\text { Fractions } \\
\text { Aqueous } \\
\text { Boiloff }\end{array}$ & $\begin{array}{l}\text { Ex. Un. } \\
\text { Onsite } \\
\text { Total } \\
\text { Sum of } \\
\text { Fractions }\end{array}$ & $\begin{array}{c}\text { Ex. Un. } \\
\text { Offsite } \\
\text { Total Sum } \\
\text { of } \\
\text { Fractions }\end{array}$ & $\begin{array}{c}\text { Unlikely } \\
\text { Onsite } \\
\text { Total Sum } \\
\text { of } \\
\text { Fractions }\end{array}$ & $\begin{array}{c}\text { Unlikely } \\
\text { Offsite } \\
\text { Total Sum } \\
\text { of } \\
\text { Fractions }\end{array}$ \\
\hline 2 & & & & & & & & & \\
\hline 3 & a & $4.45 \mathrm{E}-02$ & $7.00 E-05$ & $2.84 \mathrm{E}-03$ & $8.80 \mathrm{E}-06$ & $1.53 \mathrm{E}-01$ & $8.38 \mathrm{E}-04$ & $9.97 \mathrm{E}-01$ & $2.83 \mathrm{E}-03$ \\
\hline 4 & $b$ & $4.45 \mathrm{E}-02$ & $7.00 E-05$ & $2.78 \mathrm{E}-03$ & $8.62 \mathrm{E}-06$ & 1.30E-01 & $7.32 E-04$ & $8.12 E-01$ & $2.69 \mathrm{E}-03$ \\
\hline 6 & $c$ & $2.15 E+\infty$ & $3.37 E-03$ & 2.84E-03 & $8.80 \mathrm{E}-06$ & 2.53E-01 & $4.29 \mathrm{E}-03$ & $3.10 E+\infty$ & $6.13 E-03$ \\
\hline 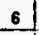 & d & $2.15 E+00$ & $3.37 E-03$ & 2.84E-03 & $8.80 E-06$ & 2.53E-01 & 4.29E-03 & $3.10 E+00$ & $6.13 E-03$ \\
\hline 7 & e & $4.45 \mathrm{E}-02$ & $7.00 E-05$ & $8.26 E-03$ & $2.56 \mathrm{E}-05$ & $5.87 \mathrm{E}-01$ & $3.34 \mathrm{E}-03$ & $3.88 \mathrm{E}+00$ & $9.79 E-03$ \\
\hline 8 & $f$ & $4.45 \mathrm{E} \cdot 02$ & $7.00 E-05$ & $1.90 \mathrm{E}-01$ & 5.88E-04 & $6.15 E+\infty$ & $7.68 \mathrm{E}-02$ & $3.86 E+01$ & 2.66E-01 \\
\hline 9 & 9 & $2.15 E+00$ & $3.37 E-03$ & $8.26 \mathrm{E}-03$ & $2.56 \mathrm{E}-05$ & 6.87E-01 & $6.75 E-03$ & $5.98 \mathrm{E}+\infty$ & $1.31 E-02$ \\
\hline 10 & h & $4.45 E-02$ & $7.00 E-05$ & $1.90 E-01$ & $5.88 E-04$ & $6.15 E+\infty$ & $7.88 \mathrm{E}-02$ & $3,86 E+01$ & $2.66 \mathrm{E}-01$ \\
\hline 11 & 1 & 7.03E-02 & $7.87 E-04$ & $0.00 E+\infty$ & $0.00 E+00$ & $0.00 E+00$ & $0.00 E+\infty$ & $0.00 E+\infty$ & $0.00 E+00$ \\
\hline 12 & 1 & 7.03E-02 & $7.87 E-04$ & $2.17 \mathrm{E}-01$ & $6.40 E-04$ & $6.45 \mathrm{E}+00$ & $8.58 \mathrm{E}-02$ & 4. $04 E+01$ & $2.90 \mathrm{E}-01$ \\
\hline 13 & $k$ & $703 E-02$ & $7.87 E-04$ & $4.72 E+03$ & $1.39 \mathrm{E}-05$ & $1.80 E-01$ & $9.34 E-04$ & $1.00 E+00$ & $4.35 E-03$ \\
\hline 14 & 1 & $7.03 E-02$ & $7.87 \mathrm{E}-04$ & $2.16 E-01$ & $6.37 E-04$ & $6.42 \mathrm{E}+00$ & $8.54 E-02$ & $4.02 E+01$ & 2.89E-01 \\
\hline 15 & $\mathrm{~m}$ & $4.46 \mathrm{E}-02$ & $4.76 E-04$ & $0.00 E+00$ & $0.00 \mathrm{E}+00$ & $0.00 \mathrm{E}+00$ & $0.00 \mathrm{E}+\infty$ & $0.00 E+\infty$ & $0.00 E+00$ \\
\hline 16 & $n$ & $4.46 \mathrm{E}-02$ & $4.76 \mathrm{E}-04$ & $1.00 E-02$ & 3.11E-05 & $7.24 E-01$ & $4.08 E-03$ & $4.68 E+\infty$ & 1.27E-02 \\
\hline 11 & 0 & $4.46 E-02$ & $4.76 E-04$ & $1.00 \mathrm{E}-02$ & 3.11E-05 & $7.24 E-01$ & $4.08 E-03$ & $4.68 \mathrm{E}+00$ & $1.27 \mathrm{E}-02$ \\
\hline 18 & $p$ & $4.46 \mathrm{E}-02$ & $4.76 \mathrm{E}-0.04$ & $1.00 \mathrm{E}-02$ & $3.11 \mathrm{E}-0.5$ & $7.24 E-01$ & $4.08 E-03$ & $4.68 E+\infty 0$ & 1.27E-02 \\
\hline 19 & 9 & $2.15 E+00$ & $3.37 \mathrm{E}-03$ & 4.24E- 03 & $1.31 E-05$ & 4.14E-01 & 5.97E-03 & $4.16 \mathrm{E}+\infty$ & $8.79 E-03$ \\
\hline 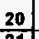 & $r$ & $2.15 E+\infty 0$ & $3.37 E-03$ & $3.90 E-03$ & $1.21 E-05$ & 4.04E-01 & \begin{tabular}{|r}
$5.83 E-03$ \\
\end{tabular} & $4.04 E+\infty$ & $8.83 E-03$ \\
\hline 21 & & & & & & & & & \\
\hline 2 & & & & & & & & & \\
\hline 24 & & & & & & & & & \\
\hline
\end{tabular}


Column $\mathrm{H}$

This column lists headspace air volume assumed for each case. In general, bounding high values were assumed in order to maximize the oxygen inventory and therefore maximize the quantity of solvent which could be burned.

Column I

This column lists the time period for which the pool fire is calculated to cause tank pressurization and outflow from the tank. The word "maximum" is included in the label descriptor because vent rate is a factor in quantifying the concentration of toxins in the downwind plume. The average vent rate during the fire-induced outflow period was found to be larger than the active ventilation flow rate (assumed to be $100 \mathrm{cfm}$ ) so the limiting toxicological consequences are associated with the outflow period listed in Column I.

For puddle fires, outflow is calculated to end well before the fire extinguishes. For example for Case a, outflow stops at $2500 \mathrm{~s}$, but the fire burns for $5018 \mathrm{~s}$ before extinguishment. Gas heatup caused by the relatively high specific burning rate computed for high oxygen concentrations is sufficient to pressurize the atmosphere for $2500 \mathrm{~s}$. For longer time, the reduced burning rate is insufficient to increase gas temperature, and venting ceases for tanks not connected to a forced ventilation system.

\section{Column $\mathrm{J}$}

Column $\mathrm{J}$ lists the masses of solvent burned during the outflow period. These numbers are smaller than the total solvent burned (Column $J$ of WSI) for puddle fires. For large pools, outflow continues for the whole of the burn period, and masses burned during the vent are equal to the total mass burned for all but the puddle fire cases. Mass burned is a calculated output of POOLFIRE.4, as detailed in Appendix A.

\section{Column $K$}

The fraction of reaction products vented during the outflow period is listed for each case in this column. $\mathrm{CO}_{2}$ is a reaction product tracked in POOLFIRE.4, and the fractional release from the tank is computed at each time step. $\mathrm{CO}_{2}$ release fraction, computed from POOLFIRE. 4 output is listed in this column.

\section{Column L}

Headspace gas fraction, defined as the fraction of headspace vented from the tank during the outflow period is listed in for each fire case. The numbers are computed from POOLFIRE.4 output. Note that the fraction of headspace gases vented is larger than the fraction of reaction products vented. The difference is explainable by the fact that reaction products are formed during the burn, whereas headspace gases are present at maximum concentration at the beginning of the vent cycle. 


\section{Column M}

The source concentration of $\mathrm{P}_{2} \mathrm{O}_{5}$, defined as the mass of $\mathrm{P}_{2} \mathrm{O}_{5}$ vented divided by the volume of gas vented, is calculated for each case. The mass of $\mathrm{P}_{2} \mathrm{O}_{5}$ formed was calculated as $4.32 \%$ of solvent mass burned as explained in Section 3.3.1. The EXCEL formula for Cell M3 is:

$$
M 3=0.0432 * \mathcal{J} 3 * K 3 * 1 E 6(\mathrm{mg} / \mathrm{kg}) /(\mathrm{H3} * \mathrm{L3})
$$

This formulation yields the average concentration during the release period. No attempt is made to compute instantaneous release rate as a function of time.

\section{Column $N$}

The average source concentration of $\mathrm{CO}$, defined as the mass of $\mathrm{CO}$ vented divided by the volume of gas vented, is calculated for each case. Based on an emission factor of $0.0425 \mathrm{~kg} / \mathrm{kg}$ (Grigsby et a]. 1995), the mass of $\mathrm{CO}$ formed is calculated to be $98 \%$ of the $\mathrm{P}_{2} \mathrm{O}_{5}$ mass. The EXCEL formula for Cell N3 is:

$$
N 3=0.98 * M 3 .
$$

\section{Column 0}

The average source concentration of $\mathrm{NO}_{2}$ vented divided by the volume of gas vented, is calculated for each case. Based on an emission factor of $5.5 \mathrm{E}-3 \mathrm{~kg} / \mathrm{kg}$, (Grigsby et a1. 1995), the mass of $\mathrm{NO}_{2}$ formed is calculated to be $12.7 \%$ of the mass of $\mathrm{P}_{2} \mathrm{O}_{5}$ formed. The EXCEL formula for Cell 03 is:

$$
03=0.127 * M 3
$$

\section{Column $P$}

The carryover rate of aqueous waste, defined as mass vented divided by the time of the vent, is calculated for each case. The EXCEL equation for Cell P3 is:

$$
P 3=N 3(\text { WS1 }) * 0.002 * K 3 / I 3
$$


WHC-SD-WM-CN-032, REV. 0

The units of column $P$ are $L / s$, so the above equation is based on the assumption of an aqueous density of $1 \mathrm{~kg} / \mathrm{L}$. This is conservative because actual waste liquids will be slightly more dense than water (dissolved material causes an increase in density).

Note that the aerosol release fraction has been assigned a value of 0.002 . In terms of Eq.(3-8) nomenclature this EXCEL equation can be written as:

$$
S / \text { time }=M * A R F * R F / \text { time }
$$

\section{Column Q}

This column lists sum of fraction multipliers for aqueous waste for onsite exposure. These values are obtained from Table 3-8 of Van Keuren (1996b). These multipliers apply to a frequency range of $10 \mathrm{E}-4$ to $10 \mathrm{E}-$ 6 events per year, termed extremely unlikely.

\section{Column $\mathrm{R}$}

This column lists sum of fraction multipliers for aqueous waste for offsite exposure. these values are obtained from Table 3-8 of Van Keuren 1996b). These multipliers apply to a frequency range of $10 \mathrm{E}-4$ to $10 \mathrm{E}-6$ events per year, termed extremely unlikely.

\section{Column S}

This column lists sum of fraction multipliers for aqueous waste for onsite exosure for a frequency range of $10^{-2}-10^{-4} \mathrm{yr}^{-1}$ (unlikely). These values are obtained from Table 3-8 of Van Keuren (1996b).

\section{Column $\mathrm{T}$}

This column lists sum of fraction multiplierss for aqueous waste for offsite exposure for a frequency range of $10^{-2}-10^{-4} \mathrm{yr}^{-1}$ (unlikely). these values are obtained from Table 3-8 of Van Keuren (1996b).

\section{Columns $U$ and $V$}

These columns compute sum of fractions for toxicological exposure for onsite and offsite individuals. The limits in Columns $Q$ and $R$ are multiplied by the aqueous release rates 1 isted in Column P. For Ce11s S3 and $T 3$, the EXCEL equations are:

$$
\begin{aligned}
& U 3=P 3 * Q 3 \\
& V 3=P 3 * R 3
\end{aligned}
$$

These values use multipliers (Columns $P$ and $Q$ ) that apply to a frequency range of $10^{-4}-10^{-6} \mathrm{yr}^{-1}$, So the sum of fractions calculated in columns $U$ and $V$ apply for the extremely unlikely frequency category. 


\section{Column W}

The vent rate of gas from the tank is calculated as the volume vented divided by the time of venting. The EXCEL equation for Cell W3 is:

$$
W 3=H 3 * L 3 / I 3
$$

Columns $X, Y$, and $Z$

Onsite concentrations for $\mathrm{P}_{2} \mathrm{O}_{5}, \mathrm{CO}$, and $\mathrm{NO}_{2}$ are computed in these three columns using Eq.(3-4). EXCEL equations are:

$$
\begin{aligned}
& X 3=0.0341 * M 3 * W 3 /(1+W 3 * 0.0341) \\
& Y 3=0.0341 * N 3 * W 3 /(1+W 3 * 0.0341) \\
& Z 3=0.0341 * 03 * W 3 /(1+W 3 * 0.0341)
\end{aligned}
$$

Note that Columns $M, N$, and 0 are source concentrations of these three contaminants.

\section{Column AA}

A normalized onsite concentration is computed with Eq. (3-4), taking $\mathrm{S}=1 \mathrm{mg} / \mathrm{mg}^{3}$. The EXCEL equation is:

$$
A A 3=0.0341 * 1 * W 3 /(1+W 3 * 0.0341)
$$

\section{Column $A B$}

Soot concentration in vented gas is computed as the mass of soot vented divided by the volume of gas vented. Soot formation is calculated as $20 \%$ of mass of solvent burned. The EXCEL equation for Cell AB3 is:

$$
A B 3=0.2 * J 3 * K 3 * 1 E 6(\mathrm{mg} / \mathrm{kg}) /(\mathrm{H} 3 * \mathrm{~L} 3)
$$

Note that Column $\mathbf{J}$ contains masses of solvent burned. 
Column $A C$

Onsite total particulate concentration is computed as the sum of onsite concentrations of soot and $P_{2} O_{5}$. The EXCEL equation for Cell AC3 is:

$$
A C 3=X 3+0.0341 * A B 3 /(1+W 3 * 0.0341)
$$

Note that Column $X$ contains onsite concentrations of $P_{2} O_{5}$.

Column $A D$

Offsite total particulate concentration is computed from Eq. (3-4), accounting for soot and $P_{2} O_{5}$. The EXCEL equation for Cell AD3 is:

$$
A D 3=2.83 E-5 *(M 3+A B 3) * W 3 /(1+W 3 * 2.83 E-5)
$$

Column $\mathrm{AE}, \mathrm{AF}$, and $\mathrm{AG}$

These columns list the onsite and offsite total particulate guideline limits. ERPG-3 and ERPG-2 guidelines (Van Keuren et a1. 1996b) are assumed to apply to onsite and offsite exposures respective $7 y$, for the extremely unlikely cataegory $\left(10^{-4}-10^{-6} \mathrm{yr}^{-1}\right)$.

CoTumn $\mathrm{AH}$

The ratio of onsite particle concentration to the extremely unlikely guideline limit is calculated for each case. The EXCEL equation for Cell AH3 is:

$$
A H 3=A C 3 / A E 3
$$

Column AI

The ratio of offsite particle concentration to the extremely unlikely guideline limit is calculated for each case. The EXCEL equation for Cell AI3 is:

$$
A I 3=A D 3 / A F 3
$$


WHC-SD-WM-CN-032, REV. 0

Column AJ

Offsite concentration is computed for a source concentration of $1 \mathrm{mg} / \mathrm{m}^{3}$ using Eq. (3-4). The EXCEL equation for Cell AJ3 is:

$$
A J 3=2.83 E-5 * 1 * W 3 /(1+W 3 * 2.83 E-5)
$$

\section{Columns AK Through BH}

These columns 1ist assumed headspace concentrations prior to a solvent fire and ERPG-3, ERPG-2, and ERPG-1 guidelines for gases in the corrosives and irritants category. These data are taken from Grigsby (1995).

Column BA lists headspace concentration of $\mathrm{P}_{2} \mathrm{O}_{5}$, and is simply a repeat of Column $M$. It is reproduced here to collect all corrosives and irritants into one section for easy comparison. Likewise, Column BE lists headspace concentrations of $\mathrm{NO}_{2}$, repeating Column 0 . Note that $\mathrm{P}_{2} \mathrm{O}_{5}$ and $\mathrm{NO}_{2}$ are reaction products whereas the other gases in this cagtegory are headspace gases that were present prior to a fire.

Columns BI through BT

These columns list headspace concentration, and guideline limits for the identified analytes which are in the systemic poison category. These numbers are taken from Grigsby et a1. 1995. Column BQ is a repeat of Column $\mathrm{N}$ and lists source concentrations of $\mathrm{CO}$ for each case. CO is a fire reaction product and is listed in this column to bring all systemic poisons together for easy comparison.

Columns BU through CR

These columns 7 ist headspace concentration (prior to a fire), and guideline limits for the identified analytes in the central nervous system toxin category. These numbers are taken from Grigsby et a). 1995.

\section{Column CS}

This column calculates the sum of fractions, onsite, for corrosives and irritants using Eq.(3-6). Onsite concentration is calculated by multiplying source concentration by the onsite normalized concentration which was calculated earlier in Column AA. The EXCEL equation for Cell CS3 is:

$$
\begin{aligned}
C S 3= & A A 3 *(A K 3 / A L 3+A O 3 / A P 3+A S 3 / A T 3+ \\
& A W 3 / A X 3+B A 3 / B B 3+B E 3 / B F 3)
\end{aligned}
$$


Note that the denominator in each fraction is the ERPG-3 value. This sum of fractions is appropriate for onsite, and a frequency range of $10^{-4}$ $10^{-6} \mathrm{yr}^{-1}$.

Column CT

Column CT calculates the sum of fractions for corrosives and irritants, offsite, using Eq.(3-6). Offsite concentration is calculated by multiplying source concentration by the offsite normalized concentration which was calculated earlier in Column AJ. The EXCEL equation for Cell CT3 is:

$$
\begin{aligned}
C T 3= & A J 3 *(A K 3 / A M 3+A O 3 / A O 3+A S 3 / A U 3+ \\
& A W 3 / A Y 3+B A 3 / B C 3+B E 3 / B G 3)
\end{aligned}
$$

Note that the denominator in each fraction is the ERPG-2 value. This sum of fractions is appropriate for offsite, and a frequency range of $10^{-4}$ $10^{-6} \mathrm{yr}^{-1}$.

Column CU

Column CU calculates the sum of fractions for systemic poisons, onsite, using Eq. (3-6). Onsite concentration is calculated by multiplying source concentration by the onsite normalized concentration which was calculated earlier in Column AA. The EXCEL equation for Cell CU3 is:

$$
C U 3=A A 3 *(B I 3 / B J 3+B M 3 / B N 3+B Q 3 / B R 3)
$$

Note that the denominator in each fraction is the ERPG-3 value. This sum of fractions is appropriate for onsite, and a frequency range of $10^{-4}$ $10^{-6} \mathrm{yr}^{-1}$.

Column CV

Column CV calculates the sum of fractions for systemic poisons, offsite, using Eq. (3-6). Offsite concentration is calculated by multiplying source concentration by the offsite normalized concentration which was calculated earlier in Column AJ. The EXCEL equation for Cel. $\mathrm{CV} 3$ is:

$$
C V 3=A J 3 *(B I 3 / B K 3+B M 3 / B O 3+B Q 3 / B S 3)
$$


Note that the denominator in each fraction is the ERPG-2 value. This sum of fractions is appropriate for offsite, and a frequency range of $10^{-4}-$ $10^{-6} \mathrm{yr}^{-1}$.

\section{Column $\mathrm{CW}$}

Column $\mathrm{CW}$ calculates the sum of fractions for central nervous system toxins, onsite, using Eq.(3-6). Onsite concentration is calculated by multiplying source concentration by the onsite normalized concentration which was calculated earlier in Column. AA. The EXCEL equation for Cell CW3 is:

$$
\begin{gathered}
C W 3+A A 3 *\left(B U_{3} / B V 3+B V_{3} / B Z_{3}+C C_{3} / C D 3+\right. \\
C G 3 / C H 3+C K 3 / C L 3+C O 3 / C P 3)
\end{gathered}
$$

Note that the denominator in each fraction is the ERPG-3 value. This sum of fractions is appropriate for onsite, and a frequency range of $10^{-4}$ $10^{-6} \mathrm{yr}^{-1}$.

\section{Column $C X$}

Column $C X$ calculates the sum of fractions for central nervous system toxins, offsite, using Eq.(3-6). Offsite concentration is calculated by multiplying source concentration by offsite normalized concentration which was calculated earlier in Column $A J$. The EXCEL equation for Cell CX3 is:

$$
\begin{aligned}
C X 3= & A_{3} 3 *\left(B U_{3} / B W 3+B W_{3} / C A 3+C C 3 / C E 3+\right. \\
& C G 3 / C I 3+C K 3 / C M 3+C O 3 / C Q 3)
\end{aligned}
$$

Note that the denominator in each fraction is the ERPG-2 value. This sum of fractions is appropriate for offsite, and a frequency range of $10^{-4}$ $10^{-6} \mathrm{yr}^{-1}$.

\section{Column CY}

This column is a repeat of Column $A H$ and lists onsite particulate fraction for each case. This column is repeated to exhibit the particulate fraction of the same page where other toxin categories are summed. This fraction is calculated using ERPG-3 limits so this column applies to a frequency range of $10^{-4}-10^{-6} \mathrm{yr}^{-1}$. 
Column $\mathrm{CZ}$

This column is a repeat of Column AI and lists offsite particulate fraction for each case. This column is repeated to exhibit the particulate fraction on the same page where other toxin categories are summed. This fraction was based on ERPG-2 values, so this column applies to a frequency range of $10^{-4}-10^{-6} \mathrm{yr}^{-1}$.

Column DA

This column lists the onsite sum of fractions for HEPA rupture. Calculational methodology is described in Sections 3.2 and 5.2.4.

Sum of fraction multipliers used apply to an accident frequency of $10^{-4}$ $10^{-6} \mathrm{yr}^{-1}$ so the results shown in this column apply to the extremely unlikely category.

Column DB

This column lists the offsite sum of fractions for HEPA rupture. Calculational methodology is described in Sections 3.2 and 5.2.4.

Sum of fraction multipliers used apply to an accident frequency of $10^{-4}$ $10^{-6} \mathrm{yr}^{-1}$ so the results shown in this column apply to the extremely unlikely category.

Column DC

This column lists the sum of fractions for HEPA rupture, onsite, for a frequency range of $10^{-2}-10^{-4} \mathrm{yr}^{-1}$, the unlikely category. Calculational methodology is described in Sections 3.2 and 5.2.4.

Column DD

This column lists the sum of fractions for HEPA rupture, offsite, for a frequency range of $10^{-2}-10^{-4} \mathrm{yr}^{-1}$, the unlikely category. Calculational methodology is described in Sections 3.2 and 5.2.4.

Column DE

This column lists the sum of fractions for aqueous boil off, onsite, for a frequency range of $10^{-4}-10^{-6} \mathrm{yr}^{-1}$. The numbers shown are copied from Column $U$, and are reproduced here to exhibit the aqueous boiloff sum of fractions on the page where other toxin category sums are displayed. 
Column DF

This column lists the sum of fractions for aqueous boiloff, offsite, for a frequency range of $10^{-4}-10^{-6} \mathrm{yr}^{-1}$. The numbers shown are copied from Column $V$, and are reproduced here to exhibit the aqueous boiloff sum of fractions on the same page where other toxin category sums are displayed.

Column DG

This column sums the sum of fractions for each category into a grand total, in accordance with Eq.(3-7). This column applies to onsite receptors and an accident frequency of $10^{-4}-10^{-6} \mathrm{yr}^{-1}$. The EXCEL equation for Cell DG3 is:

$$
D G 3=C S 3+C U 3+C W 3+C Y 3+D A 3+D E 3
$$

Column DH

This column is the grand total sum of fractions for offsite receptors for an accident frequency range of $10^{-4}-10^{-6} \mathrm{yr}^{-1}$. The EXCEL equation for Cell DH3 is:

$$
D H 3=C T 3+C V 3+C X 3+C Z 3+D B 3+D F 3 .
$$

Column DI

This column lists the sum of fractions for onsite receptors, assuming an accident frequency of $10^{-2}-10^{-4} \mathrm{yr}^{-1}$. The guidel ine for onsite, unlikely accidents is ERPG-2. The sum of fractions for all toxins is calculated by the following EXCEL formula.

$$
\begin{aligned}
D I 3= & A C 3 / A F 3+(A K 3 / A M 3+A O 3 / A Q 3+A S 3 / A U 3 \\
& +A W 3 / A Y 3+B A 3 / B C 3+B E 3 / B G 3+B I 3 / B K 3 \\
& +B M 3 / B O 3+B Q 3 / B S 3+B U 3 / B W 3+B Y 3 / C A 3 \\
& +C C 3 / C E 3+C G 3 / C I 3+C K 3 / C M 3+C O 3 / C Q 3) \\
& * A A 3+P 3 * 53+D C 3
\end{aligned}
$$

The first term is the ratio of onsite particle concentration to the ERPG2 guideline. The ratios inside the parentheses (a total of 15) are headspace concentrations divided by the ERPG-2 guideline for each headspace toxin and reaction product toxin. The sum of the ratios is multiplied by the onsite normalized concentration (cell AA3) to account 
for atmospheric dilution at the onstte location. The last two terms are sum of fractions for aqueous boiloff and HEPA rupture releases respectively.

Column DJ

This column lists the sum of fractions for offsite receptors, assuming an accident frequency of $10^{-2}-10^{-4} \mathrm{yr}^{-1}$. The guidel ine for unlikely accidents, offsite, is ERPG-1. The sum of fractions for all toxins is calculated by the following EXCEL formula.

$$
\begin{aligned}
D J 3= & A D 3 / A G 3+(A K 3 / A N 3+A O 3 / A R 3+A S 3 / A V 3 \\
& +A W 3 / A Z 3+B A 3 / B D 3+B E 3 / B H 3+B I 3 / B L 3 \\
& +B M 3 / B P 3+B Q 3 / B T 3+B U 3 / B X 3+B Y 3 / C B 3 \\
& +C C 3 / C F 3+C G 3 / C J 3+C K 3 / C N 3+C O 3 / C R 3) \\
& * A J 3+P 3 * T 3+D D 3
\end{aligned}
$$

The terms of this equation are similar to those of the equation previously described for Column DI. Since this column applies to offsite receptors, the ERPG-1 guideline is used for specific toxins. For composite materials, the sum of fractions multiplier applicable to offsite receptors and an accident frequency of $10^{-2}-10^{-4} \mathrm{yr}^{-1}$ is used. 
WHC-SD-WM-CN-032, REV. 0

\subsection{RESULTS}

Key results depicted in the spreadsheet are highlighted as follows.

\subsection{PEAK PRESSURE/VACUUMS}

For SSTs, highest peak pressure is predicted for Cases e and $\mathrm{g}$. These cases assume a large pool and a minimal vent path size. A peak pressure of 29 psig $(200 \mathrm{k} \mathrm{Pa})$ is calculated as listed in Cells H7 and H9 of WS1. Peak vacuums are calculated for Cases $f$ and $h$. These cases assume a large pool and large vents covered by flapper values. Peak vacuums of 6.8 psid are listed in Cel1s I8 and I10 of WSI.

For DSTs, a peak pressure of $30.8 \mathrm{psig}(212 \mathrm{kPa})$ and a peak vacuum of 8 psid $(55.2 \mathrm{kPa})$ are calculated and listed in Cells $\mathrm{H} 11$ and 112 respectively in WS1.

Peak pressure in a DCRT is calculated to be $30.5 \mathrm{psid}(210 \mathrm{kPa})$ as listed in Cel1 H15 of WS1. Peak vacuum in a DCRT is 1.2 psid $(8.27 \mathrm{kPa})$ as listed in Cells I16, I17, and I18 of WS1.

\subsection{RADIOLOGICAL FINDINGS}

The maximum onsite and offsite doses are calculated to be $6.09 \mathrm{E}-2 \mathrm{SV}$ and $5.34 \mathrm{E}-5 \mathrm{~Sv}$ respectively. These doses are for Case $\mathrm{g}$, and are listed in Cells K9 and L9 in WS2.

\subsection{TOXICOLOGICAL FINDINGS}

Cases a through $p$ fall in the extremely unlikely frequency category, so data listed in Columns DG and DH of WS3 are applicable for evaluatiang how calculated consequences compare with guidelines. Data in Columns DI and DJ apply to the unlikely frequency category. Only cases $q$ and $r$ fit this category, so columns DI and DJ are meaningful only for cases $q$ and $r$.

Two SST fire cases, cases $f$ and $h$, result in sum of fractions that exceed unity for onsite receptors for the extremely unlikely frequency class. The two cases that may fall into the unlikely category, $q$ and $r$, al so have sums of fractions greater than unity. These results are exhibited in cells DGB, DG10, DII9 and DI20. Two DST fire cases, cases $j$ and 1 , result in sum of fractions that exceed unity for onsite receptors. The result for these two cases are exhibited in Cells DG12 and DG 14. None of the cases result in offsite sum of fractions greater than unity. 
WHC-SD-WM-CN-032, REV. 0

\subsection{CONCLUSIONS}

Based on results of solvent pool fire analyses in SSTs, DSTs, and DCRTs, the following conclusions may be drawn.

1. Radiological consequences of poolfires are predicted to fall below guidelines, with one exception. The exception is Case $Q$, solvent entrained in sludge or saltcake. This is the wick stabilized fire. The wick stabilized fire produces a 5.62 REM on-site dose, compared to the risk acceptance guideline of 5.0 REM. This conclusion is based on the assumption that the tanks remain intact.

2. Toxicological consequences are in some cases predicted to exceed onsite guidelines for fires involving large pools in actively ventilated SSTs and DSTs. No offsite guidelines are exceeded. 


\subsection{REFERENCES}

Ayer, J. E., A. T. Clark, P. Loysen, M. Y. Ballinger, J. Mishima, P. Z. Owczarski, W. S. Gregory, and B. D. Nichols, 1988, Nuclear Fuel Cycle Facility Accident Analysis Handbook, NUREG 1320, U.S. Nuclear Regulatory Commission, Washington, D.C.

Bajwa, J. K., and Farley, W. G., 1994, Construction, Maintenance, and Operation Accident Ana7ysis, WHC-SD-WM-SARR-009, Rev. 0, Westinghouse Hanford Company, Richland, Washington.

Beite1, G. A., 1977, Exothermic Potential of Sodium Nitrate Salt Cake, ARH-LD-163, Atlantic Richfield Hanford Company, Richland, Washington.

Braun, D. J., 1992, Risk Assessment of Nitrogen Purge System for Rotary Mode Sampling Truck, WHC-SD-WM-RA-006, Westinghouse Hanford Company, Richland, Washington.

Cowley, W. L., and D. D. Stepnewski, 1994, Evaluation of Hazards to Tank Farm Facilities From Lightning Strikes, WHC-SD-WM-SARR-027, Rev. 0, Westinghouse Hanford Company, Richland, Washington.

Cowley, W. L., J. M. Grigsby, and A. K. Postma, 1996, Organic Solvents in Hanford Underground Storage Tanks, WHC-SD-WM-SARR-036, Draft, Westinghouse Hanford Company, Richland, Washington.

Cowley, W. L., 1996, Development of Radiological Concentrations and Unit Liter Doses for TWRS FSAR Radiological Consequence Calculations, WHC-SD-WM-SARR-037, Rev. 0, Westinghouse Hanford Company, Rich1 and, Washington.

Eckhof, 1991, Dust Explosions in the Process Industries,

Fink, D. G. and W. H. Beatty, 1976, Standard Handbook for Electrical Engineers, 12th Edition, McGraw-Hill.

Grigsby, J. M., and A. K. Postma, 1995, Risk from Organic Solvent Fires in C-103 Following Interim Stabilization, WHC-SD-WM-SARR-001, Supplement 1 , Revision 0-A, Westinghouse Hanford Company, Richland, Washington.

Jordan, S., and W. Lindner, 1983, "The Behavior of Burning Kerosene, Aerosol Formation and Consequences," in CSNI Specialist Meeting on Interaction of Fire and Explosion with Ventilation Systems in Nuclear Facilities Proceedings, April 25-28, Los Alamos, New Mexico.

Keller, C. M., 1991, Push Mode Core Sample Test Report, WHC-SD-WM-TRP-048, Rev. 0 , Westinghouse Hanford Company, Richland, Washington.

Kuchta, J. M., 1985, Investigation of Fire and Explosion Accidents in the Chemical, Mining, and Fuel Related Industries - A Manua7, Bullet in 680, U.S. Department of Interior, Bureau of Mines, Washington, D.C.

Lewis, 1991. 
Lindberg, S.E., 1995, Frequency Analysis of Vehicle Fuel Release Resulting in Waste Tank Fire, Internal letter \#8M400-SEL-95008, Westinghouse Hanford Company, Richland, Washington.

Mishima, J, 1994, Recommended Values and Technical Bases for Airborne Release Fractions, Airborne Release Rates and Respirable Fractions for Materials from Accidents in DOE Fuel Cycle, Ex-Reactor Facilities, Rev. 2, U.S. Department of Energy, Washington, D.C.

NFPA 321, 1991, Standard on Basic Classification of Flammable and Combustible Liquids, National Five Protection Association, Quincy, Massachussets.

Pool, K. H., and R. M. Bean, 1994, Waste Tank Safety Project: Analysis of Liquid Samples from Hanford Waste Tank 241-C-103, PNL-9402, Pacific Northwest Laboratory, Richland, Washington.

Postma, A. K., 1994, Safety Analysis of Exothermic Reaction Hazards Associated With the Organic Liquid Layer in Tank 241-C-103, WHC-SD-WM-SARR-001, Rev. 0, Westinghouse Hanford Company, Richland, Washington.

Scaief, C. C., 1991, Hydrogen Ignition Capability of Tank Farm Instrumentation and Electrical Equipment, WHC-SD-WM-ES-176, Rev. 0, Westinghouse Hanford Company, Richland, Washington.

Van Keuren, J. C., 1996a, Tank Waste Compositions and Atmospheric Dispersion Coefficients Factors for Use in Accelerated Safety Analysis Consequence Assessments, WHC-SD-WM-SARR-016, Draft, Rev. 2, Westinghouse Hanford Company, Richland, Washington.

Van Keuren, J. C., 1996b, Toxic Chemical Considerations for Tank Farm Releases, WHC-SD-WM-SARR-011, Rev. 2, Draft, Westinghouse Hanford Company, Richland, Washington.

Van Vleet, R. J., 1996, Summary of Flammable Gas Hazards and Potential Consequences in Tank Waste Remediation System Facilities at the Hanford Site, WHC-SD-WM-TI-753, Draft, Westinghouse Hanford Company, Rich Tand, Washington.

WHC-CM-4-46, 1989, Nuclear Reactor Safety Analysis Manual, Westinghouse Hanford Company, Richland, Washington.

Zach, J. J., et al, 1996, Probability, Consequences and Mitigation For Lightning Strikes to Hanford Waste Tanks, WHC-SD-WM-ES-387, Rev. 0 , Westinghouse Hanford Company, Richland, Washington.

Unknown, Structural Topical, Westinghouse Hanford Company, Richland, Washington. 
WHC-SD-WM-CN-032, REV. 0

APPENDIX A

DESCRIPTION OF POOLFIRE.3 AND POOLFIRE.4

\begin{abstract}
A. K. POSTMA
G\&P Consulting
\end{abstract}

April 8, 1996

Worked performed under contract Mod. No. 3, MKG-SCV-387934, dated 10/6/95. 
WHC-SD-WM-CN-032, REV. 0

This page intentionally left blank. 
WHC-SD-WM-CN-032, REV. 0

\section{CONTENTS}

1.0 INTRODUCTION $\ldots \ldots \ldots \ldots 7 \ldots$

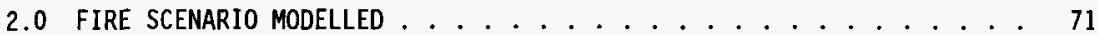

3.0 DESCRIPTION OF KEY PARAMETERS CALCULATED . . . . . . . . . . . 72

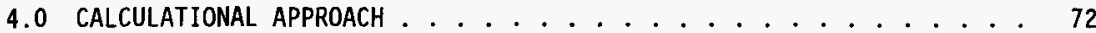

5.0 DETAILED CALCULATIONAL FORMULAE $\ldots \ldots \ldots \ldots$

5.1 GAS QUANTITY AND COMPOSITION .............. 74

5.2 HEATUP OF HEADSPACE AIR BY COMBUSTION . . . . . . . . . 81

5.3 GAS VENTING FROM (AND INTO) TANK .............. 86

5.4 HEAT TRANSFER FROM GAS TO TANK .............. . . 91

5.4.1 Heat Transport to Steel Structures . . . . . . . . 92

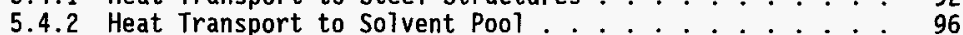

5.4.3 Heat Transport to Concrete . . . . . . . . . . 97

5.4.4 Heat Transport to Sludge . . . . . . . . . . . 101

5.5 CHANGE IN GAS TEMPERATURE DUE TO HEAT TRANSFER ...... 102

5.6 BURN RATE VERSUS OXYGEN CONCENTRATION . . . . . . . . 103

6.0 LISTING OF BASIC PROGRAMS . . . . . . . . . . . . 105

6.1 LISTING OF POOLFIRE.3 . . . . . . . . . . . . 105

6.2 LISTING OF POOLFIRE.4 ..................... 105

7.0 EXAMPLE ANALYSIS WITH POOLFIRE.3 . . . . . . . . . . 119

8.0 CONFIRMATION OF POOLFIRE. $\ldots \ldots \ldots \ldots \ldots$

9.0 LITERATURE CITED . . . . . . . . . . . . . . 131

\section{ATTACHMENTS}

A-1 APPENDIX C FROM WHC-CD-WM-SARR-001, REV. O-A, SUPPLEMENT $1 \ldots 133$

A-2 APPENDIX E OF WHC-SD-WM-SAR-046, REV. 0-A . . . . . . . . 195

A-3 MEMO FROM M. EPSTEIN OF FAI TO A. K. POSTMA, "CONFIRMATION OF POSTMA'S SOLVENT-FIRE TANK-PRESSURE TRANSIENT MODEL, "

DATED SEPTEMBER $26,1995 \ldots \ldots \ldots \ldots$

A-4 APPENDIX D OF WHC-SD-WM-SARR-001, REV. 0, SUPPLEMENT I, "CHECKLIST FOR TECHNICAL PEER REVIEW" . . . . . . . . . . . . 219

A-5 LETTER FROM C. L. BEYLER, HUGHES ASSOCIATES, INC. TO

A. K. POSTMA .................... 223 
WHC-SD-WM-CN-032, REV. 0

\section{LIST OF FIGURES}

5-1 Normalized Burn Rate Versus Oxygen Concentration . . . . . . . 104 


\section{DESCRIPTION OF POOLFIRE. 3 AND POOLFIRE. 4}

\subsection{INTRODUCTION}

This calc note describes in detail the technical basis for POOLFIRE, a basic program, which calculates a solvent fire transient in a tank.

\subsection{FIRE SCENARIO MODELLED}

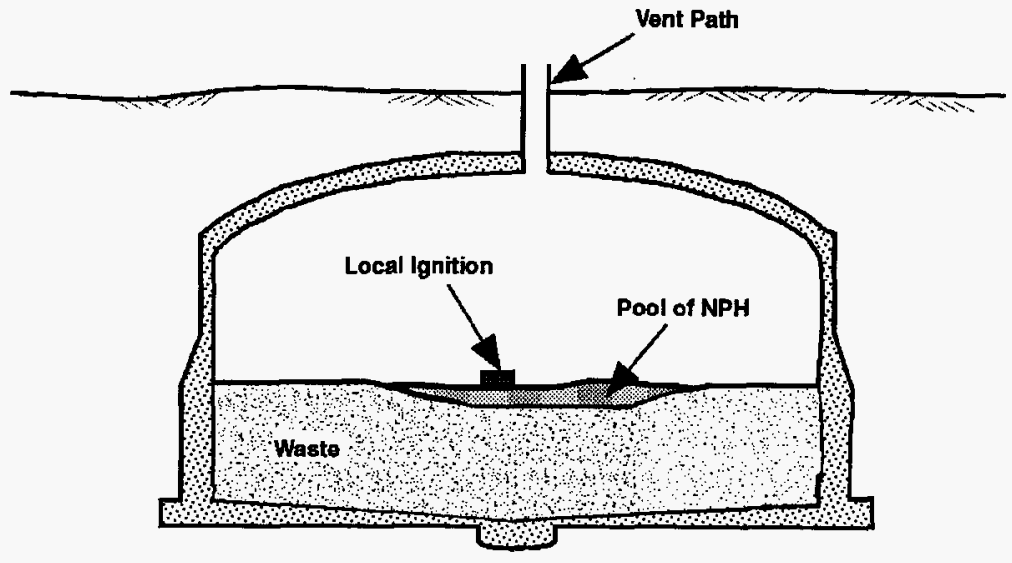

7090050291.1

Key As sumptions of Scenario

1. Local ignition of a fire is postulated, without considering the probability of ignition. In order to consider a range of possibilities, let the initial inflamed area be an input parameter.

$$
\begin{gathered}
\text { Initial inflamed area }=\pi R_{0}^{2} \\
\mathrm{R}^{\circ}=\text { input on line } 20 . \\
\text { dimensions are } \mathrm{ft} .
\end{gathered}
$$

2. The fire spreads at a fixed velocity in the radial direction. The spread velocity is a keyboard input, SPREADV. It is input on line 240 . Dimensions are $\mathrm{cm} / \mathrm{s}$. 
3. The specific burning rate is assumed to remain constant for the fire duration. The specific burning rate is treated as an input to permit parametric analyses. This parameter is called MDOTB and is input on line 20. Dimensions are $\mathrm{kg} / \mathrm{m}^{2} \mathrm{~min}$.

4. The combustion enthalpy is an input and is assumed constant for the fire duration. The symbol for this parameter is DELH and is input on line 80 . Units are BTU/1b of organic.

5. The gas phase is assumed to be well mixed at all times. This simplifying assumption is expected to yield conservative estimates of peak pressure because heat transfer from the gas to tank walls is minimized. Actual fires would have a hot layer near the ceiling which would be higher than average temperature and would radiate $\left(h-T^{4}\right)$ heat at a higher rate than calculated for the cooler, well-mixed gas case. Hormann (1983) the German who analyzed enclosed solvent fires confirms that the well-mixed model yields conservative pressures.

6. The fire self-extinguishes when a cut-off limit in oxygen concentration is reached. This was observed in all of the tests on solvent fires reported by Malet (1983). In order to perform parametric analyses, the oxygen extinguishment level is an input, on ine 20 . The symbol is X02STOP and the units are mole fraction.

7. The tank geometry is assumed to remain constant for the duration of the fire. Thus, no account is taken of vent paths that could open due to structural response (to internal pressure).

\subsection{DESCRIPTION OF KEY PARAMETERS CALCULATED}

The use of the pool fire calculation is to predict consequences of a fire. The following key parameters must be predicted.

- Tank internal pressure

- Quantity of organic burned

- Quantity of gas vented from tank

- Temperature of tank surfaces.

\subsection{CALCULATIONAL APPROACH}

The temporal variation in pressure, temperatures, and gas inventory was computed as a result of a series of burn events in which the end state for each time step was used as the initial state for the next time step. Within each time step, mass and energy balances were made to calculate temperature changes, pressure changes, and changes in inventory. 
WHC-SD-WM-CN-032, REV. 0

The overall flow of the calculational method is depicted as follows.

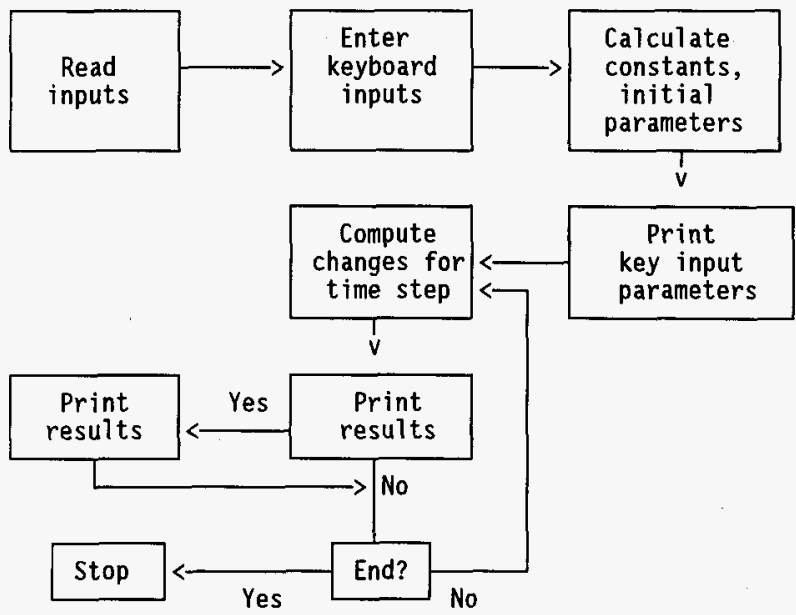

Within each time step (time steps are typically of the order of $1 \mathrm{sec}$ ) several thermodynamic process steps are analyzed to determine the temperature and pressure of confined gases. These are:

\section{Step 1: Combustion Eneray and Stoichiometry}

In step 1 , the combustion energy produced by the fire is calculated and stoichiometric calculations are made to determine gas composition at the end of the time step. These calculations are carried out in a subroutine starting at 1 ine 1800 and ending at 1 ine 1899.

\section{Step 2: Gas Heatup at Constant Volume}

In step 2, the internal energy of the gas inventory was increased by the quantity of combustion energy calculated in step 1 . This heatup calculation is performed in a subroutine starting at line 1900 and ending at line 1995.

\section{Step 3: Gas Venting and Expansion Work}

The quantity of gas vented from the tank during a time step was computed on the basis of pressure difference and flow path admittance. The gas in the tank was assumed to undergo an isentropic expansion. Venting and expansion work are calculated in a subroutine starting at line 2000 . For times when the 
WHC-SD-WM-CN-032, REV. 0

tank pressure is higher than atmospheric pressure, the subroutine ends at line 2290. When internal pressure is less than atmospheric pressure, a branch of the routine (starting at line 2280) goes to a subroutine starting at line 3000 and ending at 1 ine 3290 . For inflow, the step 1 calculations are bypassed, and gas composition is calculated for mixing of contained gases with inflowing atmospheric air. This mixing calculation is done in the subroutine starting at Tine 3000 and ending at line 3290 .

\section{Step 4: Heat Transfer to Surfaces}

Heat transfer from the gas to tank surfaces was computed by accounting for radiation and convection. Gas inventory was held constant for this step. Temperature and pressure computed at the end of this step were used as initial values for the next time increment, starting again at step 1 . The heat balance calculations are carried out in subroutines starting at 1 ines 2300 , 2600,2700 , and 2800 . The subroutine starting at line 2300 computes heat flux from gas to concrete and organic pool areas. Similarly, the subroutine starting at 1 ine 2800 computes heat flux to sludge surfaces. The subroutine starting at 1 ine 2600 computes heat flux from gas to steel surfaces. Finally, the change in gas temperature due to heat transfer is computed in the subroutine starting at line 2700 . In addition to calculating heat flux, each of the subroutines cited above also calculated the transient heatup of the surface involved.

\section{Sequential Versus Simultaneous Processes}

The four step approach identified above treats heat transfer and outflow as sequential steps. In reality these processes occur simultaneously. The validity of the sequential process treatment can be verified by analyzing a given problem using a series of smaller and smaller time steps. For sufficiently small steps, no significant difference in results will appear when a smaller step is used. For the cases analyzed herein, little difference in calculated results was seen when time steps were reduced from $10 \mathrm{~s}$ to $0.1 \mathrm{~s}$. Most runs were made with time steps in the range of $0.1 \mathrm{~s}$ to $1 \mathrm{~s}$. The reason that the sequential steps work ok is that very little change in temperature, pressure, or gas inventory occurs during the small steps employed.

\subsection{DETAILED CALCULATIONAL FORMULAE}

In this section, the equations used to quantify the various parameters are presented.

\subsection{GAS QUANTITY AND COMPOSITION}

The quantity of gases within the tank is computed by means of the ideal gas law. Initial quantities are computed as follows. 


$$
\text { MTOT }=\text { PTOTE } \bullet \text { GVOL } /(R * T)
$$

where

$$
\begin{aligned}
& \text { MTOT }=\text { Total mols (1b mols) } \\
& \text { PTOTe }=\text { Initial absolute pressure (psia) } \\
& \text { GVOL }=\text { Gas volume in tank }\left(\mathrm{ft}^{3}\right) \\
& R \quad=\text { Gas constant }\left(10.73 \mathrm{psi}^{3} \mathrm{ft}^{3} /{ }^{\circ} \mathrm{R}\right. \text { mol) } \\
& \mathrm{R} \quad=\text { Absolute temperature }\left({ }^{\circ} \mathrm{R}\right) .
\end{aligned}
$$

This calculation is done at line 330. PTOTe, GVOL, and T are input values on lines 40,80 , and 50 , respectively. The initial gas temperature is specified as $T G \theta$ in ${ }^{\circ} \mathrm{F}$ on line 50 .

A second step is to calculate the initial mols of water vapor on the basis of an inputted initial water vapor pressure, PWATo.

$$
\mathrm{MH}_{2} \mathrm{O}=\text { PWATӨ * GVOL / }(\mathrm{R} * \mathrm{~T})
$$

where

$$
\begin{aligned}
& M_{2} 0=\text { Mols of water vapor } \\
& \text { PWAT }=\text { Initial water vapor pressure ( } p \text { sia) } .
\end{aligned}
$$

PWATe is an input value on line 80 .

Initial gas is assumed to be made up of water vapor and air (composed of $79 \% \mathrm{~N}_{2}$ and $21 \% \mathrm{O}_{2}$ ). Nitrogen and oxygen moles (initially present) are computed from:

$$
\mathrm{MN}_{2}=0.79 \cdot\left(\text { MTOT }-\mathrm{MH}_{2} \mathrm{O}\right)
$$

and

$$
\mathrm{MO}_{2}=0.21 \cdot\left(\mathrm{MTOT}-\mathrm{MH}_{2} \mathrm{O}\right)
$$

where

$$
\begin{aligned}
& \mathrm{MN}_{2}=\text { Initial mols of nitrogen } \\
& \mathrm{MO}_{2}=\text { Initial mols of oxygen. }
\end{aligned}
$$


WHC-SD-WM-CN-032, REV. 0

The mole fraction of oxygen in contained gases is computed as:

$$
\mathrm{XO}_{2}=\mathrm{MO}_{2} / \mathrm{MTOT}
$$

where

$\mathrm{XO}_{2}=$ 0xygen mole fraction.

These calculations are carried out in lines 320 through 365 .

The gas composition is recalculated at each time step to account for combustion and leakage. The combustion effects are computed in lines 1800 through 1899 and are described as follows.

First, the average burn area is computed for the time step.

$$
\text { BURNAR }=3.1416 *(R \Theta+(T I M+D T / 2) \cdot(B U R N R-R \Theta) / T I M S) \wedge 2
$$

where

$$
\begin{aligned}
& \text { BURNAR = Inflamed area of pool }\left(\mathrm{ft}^{2}\right) \\
& \text { Re }=\text { Radius of initial inflamed area }(\mathrm{ft}) \\
& \text { TIM }=\text { Time from fire initiation (sec) } \\
& \text { DT }=\text { Length of time step (sec) } \\
& \text { BURNR }=\text { Pool radius corresponding to the whole organic surface area ( } \mathrm{ft} \text { ) } \\
& \text { TIMS }=\text { Time of fire spread across the whole organic surface }(\mathrm{sec}) .
\end{aligned}
$$

BURNR and TIMS are constants for the problem and are computed at line 310 and line 395 , respectively.

Second, the total burn rate is computed as the product of inflamed area and specific burn rate.

$$
\text { BRATE }=\text { BURNAR }- \text { MDOTB }
$$

where

BRATE $=$ Burn rate of organic $(1 \mathrm{~b} / \mathrm{s})$

MDOTB $=$ Specific burn rate $\left(1 \mathrm{~b} / \mathrm{s} \mathrm{ft}^{2}\right)$.

Note that MDOTB was converted to English units in line 605.

The total integrated mass of organic burned is computed from:

$$
\text { MASSBURN }=\text { BRATE }-D T+\text { MASSBURN }
$$

where

MASSBURN = Total organic combusted (1b). 
Combustion products are quantified on the basis of NPH and TBP reacting with $\mathrm{O}_{2}$ to produce $\mathrm{CO}_{2}$ and $\mathrm{H}_{2} \mathrm{O}$. NPH is represented by dodecane, and reacts according to:

$$
\mathrm{C}_{12} \mathrm{H}_{26}+18.5 \mathrm{O}_{2}=12 \mathrm{CO}_{2}+13 \mathrm{H}_{2} \mathrm{O}
$$

TBP is assumed to react according to:

$$
\mathrm{C}_{12} \mathrm{H}_{27} \mathrm{PO}_{4}+18 \mathrm{O}_{2}=12 \mathrm{CO}_{2}+13.5 \mathrm{H}_{2} \mathrm{O}+\frac{1}{2} \mathrm{P}_{2} \mathrm{O}_{5}
$$

Overal1, stoichiometry is based on $84 \%$ by mass of dodecane and $16 \%$ by mass TBP. These mass ratios were determined experimentally for vapor equilibrium above $\mathrm{C}-103$ organic by Pool and Bean (1994) at $100{ }^{\circ} \mathrm{C}$.

Basis: $11 \mathrm{~b}$ of fuel vapor

$$
\begin{gathered}
\text { mols } \mathrm{C}_{12} \mathrm{H}_{26}=0.84 / 170.33=4.932 \mathrm{E}-3 \\
\text { mols } T B P=0.16 / 266.32=6.008 \mathrm{E}-4 \\
\text { Total mols }=4.932 \mathrm{E}-3+6.008 \mathrm{E}-4=5.53 \mathrm{E}-3 \\
\text { mol wt. of mixture }=1 / 5.532 \mathrm{E}-3=180.8
\end{gathered}
$$

Basis: 1 mol of fuel $(1 \mathrm{~mol})$

$$
\begin{aligned}
& \text { mols } \mathrm{C}_{12} \mathrm{H}_{26}=\frac{0.84(180.8)}{170.33}=0.8914-\mathrm{C}_{12} \\
& \text { mols TBP }=\frac{0.16(180.8)}{266.32}=0.1086-\mathrm{TBP} \\
& \frac{\text { mols } 0_{2} \text { reacted }}{\text { mol fuel }}=0.8914(18.5)+0.1086(18)=18.45
\end{aligned}
$$


WHC-SD-WM-CN-032, REV. 0

$$
\begin{aligned}
& \frac{\mathrm{mols} \mathrm{H}_{2} \mathrm{O} \text { formed }}{\text { mol fuel }}=0.8914(13)+0.1086(13.5)=13.05 \\
& \frac{\mathrm{mols} \mathrm{\textrm {CO } _ { 2 } \text { formed }}}{\text { mol fuel }}=0.8914(12)+0.1086(12)=12.0
\end{aligned}
$$

The mols of fuel burned during a time step is computed in 1 ine 1840 by:

$$
\text { DMF }=\text { BRATE } \bullet \text { DT } / 180.8
$$

where

DMF $=$ mols fuel burned in time step.

The total inventory of combustion products is then updated by adding the increment in lines 1855 through 1870 .

$$
\begin{gathered}
1855 \mathrm{MH}_{2} \mathrm{O}=\mathrm{MH}_{2} \mathrm{O}+\mathrm{DMF} \cdot 1305 \\
1860 \mathrm{MO}_{2}=\mathrm{MO}_{2}-18.45 \cdot \mathrm{DMF} \\
1865 \mathrm{MCO}_{2}=\mathrm{MCO}_{2}+12 \cdot \mathrm{DMF} \\
1867 \mathrm{TOTCO}_{2}=\mathrm{TOTCO}_{2}+12 \cdot \mathrm{DMF}
\end{gathered}
$$

where

TOTCO $\mathrm{T}_{2}=$ Total $\mathrm{CO}_{2}$ formed by combustion.

Total $\mathrm{CO}_{2}$ formed by combustion is used as a tracer gas to determine the fraction of combustion products vented from the tank during the course of a fire.

$$
1870 \text { MTOT }=\mathrm{MH}_{2} \mathrm{O}+\mathrm{MO}_{2}+\mathrm{MN}_{2}+\mathrm{MCO}_{2}
$$


where

$$
\mathrm{XO}_{2}=\text { Mole fraction of } \mathrm{O}_{2} .
$$

Oxygen mole fraction is calculated at each burning time step and is compared with the extinguishment level inputted as XO2STOP.

An IF statement (at line 1805) bypasses the combustion product material balance sequence for times after the fire is out.

For times when the fire is out and the tank is pressurized as compared to the outside atmosphere, the gas inventory is depleted by the fraction vented during the time step. This is done in a subroutine starting at 1 ine 2000 , in lines 2170 through 2220 :

$$
\begin{aligned}
2170 \mathrm{MH}_{2} \mathrm{O} & =\mathrm{MH}_{2} \mathrm{O} / \text { VRATIO } \\
2180 \mathrm{MO}_{2} & =\mathrm{MO}_{2} / \text { VRATIO } \\
2190 \mathrm{MN}_{2} & =\mathrm{MN}_{2} / \text { VRATIO } \\
2200 \mathrm{MCO}_{2} & =\mathrm{MCO}_{2} / \text { VRATIO: } \\
\mathrm{FCO}_{2} & =\mathrm{MCO}_{2} / \text { TOTCO } \\
2220 \mathrm{MTOT} & =\text { MTOT } / \text { VRATIO }
\end{aligned}
$$

In the above equation, VRATIO is the calculated vent factor in line 2120 and 1 ine 2125 .

$$
\begin{aligned}
& 2120 \quad V_{2}=G V O L+F V O L \\
& 2125 \quad \text { VRATIO }=V_{2} / G V O L
\end{aligned}
$$


where

$V_{3}=$ Total of contained volume and vented volume

FVOL $=$ Volume of gas vented at tank conditions $\left(\mathrm{ft}^{3}\right)$.

When the tank internal pressure falls below that of the outside atmosphere, atmospheric air inflows through the leak path. Inflowing air is assumed to be air at $55^{\circ} \mathrm{F}$ (the average annual Hanford Site temperature) and contain water vapor at $50 \%$ relative humidity.

Basis: 1 mol of outside air

$\mathrm{H}_{2} \mathrm{O}$ vapor pressure at $55^{\circ} \mathrm{F}=0.222 \mathrm{psi}$

At $50 \% \mathrm{RH}$, vapor pressure $=0.5(0.222)=0.11 \mathrm{psi}$

For a total pressure of 14.5 psia (Hanford annual average)

$\mathrm{H}_{2} \mathrm{O}$ mole fraction $=\frac{0.11}{14.5}=0.0076$

Dry air mole fraction $=1-0.0076=0.992$

Mole fraction of $N_{2}=0.79(0.992)=0.784$

Mole fraction of $\mathrm{O}_{2}=0.21(0.992)=0.208$.

For the inflow time period, the gas inventory is computed for each time step in lines 3180 to 3210 , in a subroutine starting at line 3000 .

$$
\begin{gathered}
3180 \mathrm{MH}_{2} \mathrm{O}=\mathrm{MH}_{2} \mathrm{O}+\mathrm{INMOLS} * 0.008 \\
3190 \quad \mathrm{MO}_{2}=\mathrm{MO}_{2}+\text { INMOLS } * 0.208 \\
3200 \quad \mathrm{MN}_{2}=\mathrm{MN}_{2}+\text { INMOLS } \bullet .784 \\
3210 \quad \text { MTOT }=\text { NEWMOLS }
\end{gathered}
$$

3120 NEWMOLS $=$ INMOLS + MTOT 
In Equations 26 througl 30 , INMOLS is the quantity of air predicted to flow into the tank during a time step.

As described in this section (5.1) equat lons 1 through 30 are used to calculate the inventory and composition of headspace gases.

\subsection{HEATUP OF HEADSPACE AIR BY COMBUSTION}

The heatup of headspace gas by combustion is treated as a constant volume process. The sensible heat gain is equated to the enthalpy of combustion:

$$
\Delta T=\frac{\Delta H}{M C_{v}}
$$

where

$$
\begin{aligned}
\Delta T & =\text { Increase in temperature }\left({ }^{\circ} \mathrm{F}\right) \\
\Delta H & =\text { Effective enthalpy of combustion (BTU) } \\
M & =\text { Total mols of gas } \\
C_{v} & =\text { Average heat capacity at constant volume (BTU/mol) } .
\end{aligned}
$$

This computation is carried out in a subroutine starting at 7 ine 1900 and ending at line 1995. An iterative procedure is used to account for the change in $C_{v}$ with temperature.

The heat capacity of each gas was related to temperature by means of a quadratic equation:

$$
C_{p}=A+B T+C T^{2}
$$

where

$C_{p}=$ Heat capacity at constant pressure

$A, B, C=$ Constants

$T=$ Absolute temperature.

The average heat capacity over a temperature interval can be calculated by integrating equation 32 with respect to temperature and dividing by the interval:

$$
C_{p}(a v g)=\frac{1}{\left(T_{2}-T_{1}\right)} \int_{1}^{T_{2}}\left(A+B T+C T^{2}\right) d T
$$

Carrying out the integration, 


$$
C_{p} \text { (avg) }=A+\frac{B}{2}\left(T_{1}+T_{2}\right)+\frac{C}{3}\left(T_{2}^{2}+T_{1} T_{2}+T_{1}^{2}\right)
$$

Heat capacity at constant volume, $C_{v}$, can be estimated from $C_{p}$ by:

$$
C_{v}=C_{p}-R
$$

where

$$
R=\text { Ideal gas constant }\left(1.987 \mathrm{cal} / \mathrm{mole}^{\circ} \mathrm{K}\right) \text {. }
$$

The constants, $A, B$, and $C$ were taken from data presented by Hougen (et al. 1954). $T_{1}$ in equat of on 34 is taken as the initial gas temperature and $\mathrm{T}_{2}$ is predicted by a predictor-corrector iterative routine as described on lines 1905, 1907, 1910, 1920, 1982, 1985, and 1990. and 1940:

The temperature factors in equat. on 34 are calculated in 7 ines 1930

$$
1930 A=T_{1}+T_{2}
$$

$$
1940 B=\mathrm{T} 2 \mathrm{~T}_{2}+\mathrm{T}_{1} * \mathrm{~T}_{2}+\mathrm{T}_{1}^{2}
$$

Then average heat capacities for each of the gases tracked are computed.

$$
\begin{aligned}
& \mathrm{C}_{v} \mathrm{H}_{2} \mathrm{O}=5.149+\mathrm{A} * 0.000733+4.72 \mathrm{E}-09 \mathrm{~B} \\
& \text { where } \mathrm{CvH}_{2} \mathrm{O}=\text { for } \mathrm{H}_{2} \mathrm{O} \text { vapor. }
\end{aligned}
$$




$$
\begin{aligned}
& 1955 \quad C_{v} N_{2}=4.47+A * 0.000386-B * 7.1 E-9 \\
& \text { where } C_{2} N_{2}=C_{v} \text { for nitrogen. } \\
& 1960 \quad C_{v} O_{2}=4.13+0.00088 * A-1.03 E-7 * B \\
& \text { where } C_{v} O_{2}=C_{v} \text { for oxygen. } \\
& 1965 \quad C_{v} C_{2}=4.352+0.00281 * A-3.51 E-7 * B \\
& \text { where } C_{v} C_{2}=C_{v} \text { for } \mathrm{CO}_{2} .
\end{aligned}
$$

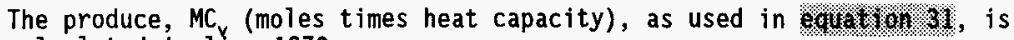
then calculated in 1 ine 1970 .

$$
1970 M C_{v}=M_{2} \mathrm{O} * \mathrm{C}_{v} \mathrm{H}_{2} \mathrm{O}+\mathrm{MN}_{2} * \mathrm{C}_{\mathrm{V}} \mathrm{N}_{2}+\mathrm{MO}_{2} * \mathrm{C}_{\mathrm{v}} \mathrm{O}_{2}+\mathrm{MCO}_{2} * \mathrm{C}_{\mathrm{v}} \mathrm{CO}_{2}
$$

where

$$
M C_{v}=M C_{v} \text { for headspace gas. }
$$

The temperature increase due to combustion is calculated in line 1980:

$$
D E L T G=(D E L E-F S E N S) / M C_{v}
$$

where

$$
\text { DELTG }=\Delta T \text { rise in }{ }^{\circ} \mathrm{F} \text {. }
$$

The variable DELE is the total combustion energy for the time step and was computed on line 1830 in the combustion subroutine:

$$
1830 \text { DELE = BRATE * DELH • DT }
$$

where

$D E L E=B T U$ of combustion energy. 


$$
\frac{1 b}{s} * \frac{B T U}{16} * s=B T U
$$

As shown in eowativon 48 the endotherm required to heat fuel vapor from the fire point to the headspace gas temperature is deducted from combustion enthalpy.

This endotherm was calculated in a subroutine starting at line 3300 .

$$
3310 T_{1}=758
$$

$T_{1}$ is the temperature of vapor leaving the pool, and was based on the estimated fire point of the fuel. The fire point of the fuel was estimated by adding $30^{\circ} \mathrm{C}$ to the measured flash point:

$$
\mathrm{T}_{1}=118+30=148^{\circ} \mathrm{C}=758^{\circ} \mathrm{R}
$$

$$
3320 \quad T_{2}=T G
$$

$T_{2}$ is the headspace gas temperature, at which it is assumed the combustion takes place. Lines 3330,3340 , and 3350 are used to compute the average heat capacity of fuel vapor, using quadratic coefficients evaluated for dodecane using a correlation from Hougen (et a1. 1954). The quantities $A$ and $B$ are temperature factors defined in equat 890,36 . ano $3 \%$. The molar heat capacity of dodecane vapor (BTU/lb mol) is calculated at line 3350:

$$
3350 \text { CPFUEL }=0.478+0.0686 * A-8.63 E-6 * B
$$

The sensible heat endotherm attributable to heating of fuel vapor from the firepoint to the current gas temperature is calculated in 1 ine 3360 :

$$
3360 \text { FSENS }=\left(T_{2}-T_{1}\right) \cdot \text { CPFUEL * DMF }
$$

where

FSENS = Unreacted fuel vapor endotherm (BTU). 
WHC-SD-WM-CN-032, REV. 0

The combustion process modelled here is depicted as follows.

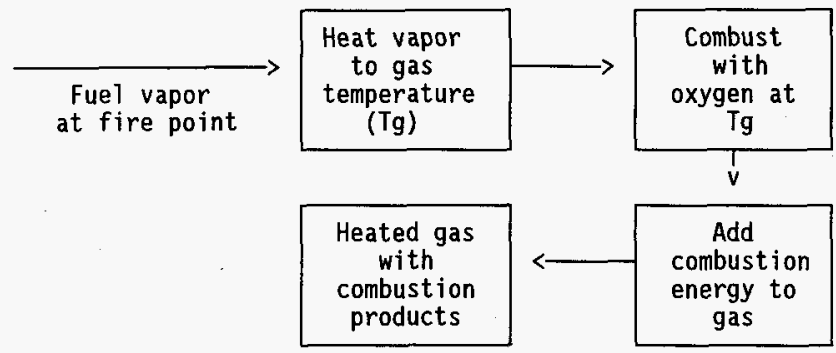

The vapor endotherm, FSENS, is sma11 compared to combustion energy, DELE. Predicted gas, pressures, and temperatures are therefore not significantly affected by the FSENS term.

The combustion enthalpy, $\Delta H_{R}$, varies with temperature if the products and reactants have different heat capacities. The reaction enthalpy at a temperature $\mathrm{T}$, may be computed from the value at $298^{\circ} \mathrm{K}$ as follows (Daniels and Alberty 1955):

$$
\Delta H_{T}-\Delta H_{298}=\int_{298}^{T} \Delta C_{p} d T
$$

where

$$
\begin{aligned}
\Delta H_{T} & =\text { Combustion enthalpy at } T \\
\Delta H_{298} & =\text { Combustion enthalpy at } 298^{\circ} \mathrm{K} \\
\Delta C_{p} & =\Sigma C_{p} \text { (products) }-\Sigma C_{p} \text { (reactants) } \\
T & =\text { Absolute temperature. }
\end{aligned}
$$

Numerical evaluation of equato on 50 indicated that the change in combustion enthalpy was less than $1 \%$ over the temperature range of interest. This variation is too small to significantly affect calculated temperatures and pressures, and was neglected, i.e., $\Delta H_{298}$ was not corrected for temperature.

The final step in the heatup calculation is to compute the magnitude of the temperature rise for contained gases at constant volume. 


$$
\begin{gathered}
1980 \text { DELTG }=\left(\text { DELE - FSENS) } / M C_{v}\right. \\
1990 \quad \mathrm{Tg}=\mathrm{Tg}+\mathrm{DELTG}
\end{gathered}
$$

where

$D E L T G=$ Rise in gas temperature $\left({ }^{\circ} R\right)$

$\mathrm{Tg}=$ Gas temperature $\left({ }^{\circ} \mathrm{R}\right)$. capacity.

Note that the final value of DELTG is based on five iterations on heat

\subsection{GAS VENTING FROM (AND INTO) TANK}

The tanks are not leak-tight and will vent gas when pressurized, or take in atmospheric air when at negative pressure. Two effects are:

- Gain or loss in gas inventory

- Expansion work done by gas remaining in tank.

Gas venting rates and effects are computed in a subroutine starting at line 2000 .

Since relative high internal gas pressures can theoretically develop as a result of a fire, compressible effects may be important in limiting venting velocities. Flow rates through vent paths was modeled as a gas flow through an orifice, using the American Society of Mechanical Engineers orifice equation presented by Perry (1950 p. 403).

$$
W=Q_{1} P_{1}=C Y S_{2} \sqrt{\frac{2 G_{c}\left(P_{1}-P_{2}\right) / P_{1}}{1-B^{4}}}
$$

where

$$
\begin{aligned}
W & =\text { Mass flow rate }(1 \mathrm{~b} / \mathrm{s}) \\
Q & =\text { Volumetric flow rate }\left(\mathrm{ft}^{3} / \mathrm{s}\right) \\
\mathrm{P}_{1} & =\text { Density at upstream conditions }\left(1 \mathrm{~b} / \mathrm{ft}^{3}\right) \\
\mathrm{C} & =\text { Coefficient of discharge } \\
Y & =\text { Expansion factor } \\
\mathrm{G}_{\mathrm{c}}= & \text { Gravitational constant }\left(32.171 \mathrm{~b}_{\mathrm{m}} \mathrm{ft} / 1 \mathrm{~b}_{\mathrm{f}} \mathrm{sec}^{2}\right) \\
\mathrm{P}_{1}, \mathrm{P}_{2}= & \text { Pressures upstream and downstream }\left(1 \mathrm{~b}_{f} / \mathrm{ft}^{2}\right) \\
\mathrm{B}^{2}= & \text { Ratio of cross-section of constriction to that of upstream } \\
& \text { channel } \\
\mathrm{S}_{2}= & \text { Cross sectional area of discharge opening }\left(\mathrm{ft}^{2}\right) .
\end{aligned}
$$


Gas velocity calculated in the orifice was compared to sonic velocity, and the maximum allowed velocity was sonic velocity.

Actual vent paths are not circular orifices, so an equivalent orifice, i.e., one that delivered the same gas flow at the maximum pressure difference, was separately calculated and treated as an input parameter. The method for predicting adiabatic flow through pipes is explained in Section 6.1.4.6 of Appendix $C$ of Grigsby (et al. 1995) (Attachment 1).

A first step in the flow estimate is to compute the average value of $C_{v}$.

$$
2020 C_{v} A V G=M C_{v} / \text { MTOT }
$$

where

$$
\begin{aligned}
& C_{v} A V G=\text { Average value of } C_{v} \\
& M C_{v}=\Sigma M C_{v} \text { (from line 1970) } \\
& \text { MTOT }=\text { total gas mols. }
\end{aligned}
$$

Headspace gas pressure at the beginning of the time step is then calculated from the ideal gas law.

$$
2030 P_{1}=\text { MTOT } * \text { TG * ROV }
$$

where

$P_{1}=$ Initial gas pressure

$\mathrm{ROV}=$ Gas constant/gas volume (1 ine 380 ).

The ratio of downstream to upstream absolute pressure is calculated.

$$
2040 \text { PRATIO }=\text { PTOTO } / \text { PAV }
$$

where

PAV = Average tank pressure ( 1 ine 2035).

Lines 2042, 2044, 2046, and 2048 check to see if tank pressure is sufficiently high to open the salt well vent. If sufficiently high, the flow area is increased to account for the salt well vent path. The expansion factor ( $Y$ of equatton 53 ) is computed in line 2050.

$$
2050 \text { YFACT }=1-0.315 *(1-\text { PRATIO })
$$


This estimate of the expansion factor is based on a formula presented by Perry (1950 p. 403) for square edged orifices. As a simplification, $B^{2}$

(equation 53) was set equal to zero and the specific heat ratio was set equal to 1.3 , a value applicable to air. Perry's formula for $Y$ is:

$$
Y=1-\left[\frac{P_{1}-P_{2}}{P_{1} K}\right]\left(0.41+0.35 B^{4}\right)
$$

where the terms are as defined in egrat on $\$ 3$, with an additional term, $K=$ specific heat ratio $=C_{p} / C_{v}$.

Sonic velocity in air at temperature TG is then calculated.

$$
2060 \text { SONIC }=47.2 * \mathrm{TG} \wedge 0.5
$$

where

SONIC = Sonic velocity $(\mathrm{ft} / \mathrm{sec})$.

The constant in earatroa $\$ \checkmark$ is calculated on the basis of sonic velocity in an ideal gas (Hougen et al. 1959, p. 695):

$$
a=\left(\frac{g_{c} K R T}{M}\right)^{\frac{1}{2}}
$$

where

$$
\begin{aligned}
& \mathrm{a}=\text { Sonic velocity } \\
& \mathrm{K}=\text { Specific heat ration (assumed } 1.3 \text { ) } \\
& \mathrm{R}=\text { Ideal gas constant } \\
& T=\text { Absolute temperature ( } \\
& \mathrm{O} \\
& \mathrm{O} \text { ) } \\
& M=\text { Molecular weight of gas (assumed } 2 \mathrm{~g} \text { ). }
\end{aligned}
$$

The Bernoulli velocity $\left(\mathrm{V}^{2}=2 \mathrm{~g}_{\mathrm{c}} \Delta \mathrm{P} / e\right)$ in the orifice is calculated as a function of pressure drop.

$$
2080 \text { VEL }=96.3 *[(\text { PAV }- \text { PTOTO }) / \text { RHOGAS }] \wedge 0.5
$$

where

$$
\begin{aligned}
& \text { VEL } \\
& \text { RHOGAS Velocity in throat (ft/sec) } \\
& \text { PAV, PTOTO = Gas density from line } 2070\left(1 \mathrm{~b} / \mathrm{ft}^{3}\right) \\
& \text { Pressures in psia. }
\end{aligned}
$$

The Bernoulli velocity is compared with sonic velocity in 1 ine 2090 , and the lesser of these two is used as throat velocity (1 ine 2090). Flow rate of 
vented gas is calculated in line 2095:

$$
2095 \text { FLRATE }=\text { ORIFC - FAREA - YFACT * VEL }
$$

where

$$
\begin{aligned}
& \text { FLRATE }=\text { Gas flow rate }\left(\mathrm{ft}^{3} / \mathrm{sec}\right) \\
& \text { ORIFC }=\text { Orifice coefficient (an input) } \\
& \text { FAREA }=\text { Orifice open area }\left(\mathrm{ft}^{2}\right) .
\end{aligned}
$$

The volume of gas expelled from the tank during the step is calculated as the product of flow rate and time.

$$
2100 \text { FVOL }=\text { FLRATE * DT }
$$

where

FVOL = Gas volume expelled at upstream conditions.

The ratio of specific heats, $C_{p} / C_{v}$, is calculated in line 2110 , assuming idea] gas behavior where $C_{p}-C_{v}=R$.

$$
2110 \text { KAPPA }=\left(C_{V} A V G+1.987\right) / C_{V} A V G
$$

where

$$
\text { KAPPA }=C_{p} / C_{v} .
$$

The expanded volume (headspace volume plus outflow volume) is then calculated in line 2120 .

$$
2120 \quad V_{2}=G V O L+F V O L
$$

where

$$
V_{2}=\text { expanded gas volume }\left(\mathrm{ft}^{3}\right) \text {. }
$$

The expansion ratio, $V_{2} / \mathrm{GVOL}$, is then calculated in line 2125 , and used to calculate final pressure for an adiabatic, isentropic expansion:

$$
2130 \quad P_{2}=P_{1} / \text { VRATIOAKAPPA }
$$


This expression for $P_{2}$ derives from the formula for a reversible expansion (Hougen et a). 1959, p. 648):

$$
P_{2}=\frac{P_{1}}{\left[\frac{V_{2}}{V_{1}}\right]^{X}}
$$

where

$$
\begin{array}{ll}
P & =\text { Pressure } \\
T & =\text { Temperature } \\
K & =\text { Specific heat ratio } \\
1,2 & =\text { Indicate conditions before and after the expansion. }
\end{array}
$$

Temperature in the expanded gas is then computed from the ideal gas law.

The volume of expelled air is then summed in 1 ine 2152, and given the symbol FVOLTOT. The temperature drop caused by the adiabatic expansion is calculated in line 2165 by subtracting the final temperature from the initial temperature. These two variables were calculated to aid in verifying the numerics of the program but are not used directly in consequence calculations.

The area for gas flow is computed as the open area of the equivalent orifice. The initial flow area; symbolized as FAREA input value of orifice diameter in line 385 :

$$
\text { FAREA } \Theta=0.7854 *(\text { DORF } / 12)^{2}
$$

where

$$
\begin{aligned}
& \text { FAREA }=\text { Orifice open area }\left(\mathrm{ft}^{2}\right) \\
& \text { DORF }=\text { Diameter of orifice (in.). }
\end{aligned}
$$

DORF is a keyboard input on line 210. A second vent path is allowed for in line 215, where an input orifice diameter for a salt wel1 vent is requested. This vent path is modelled as a path that opens when a specified internal tank pressure is exceeded. The orifice area for this vent path is computed in line 217, using the same formula indicated in equaw 601.68 . The opening of the salt well vent is computed in lines 2042 to 2048 . The fraction open is computed in line 2044 by:

$$
\text { FRACTION = PAV - PLIFT }
$$

where

$$
\begin{aligned}
& \text { FRACTION = Open area fraction } \\
& \text { PAV } \\
& \text { PLIFT Internal tank pressure (psia) }
\end{aligned}
$$


The formula expressed in eavelon. 69 causes the salt well vent to be fully open when internal tank pressure exceeds the PLIFT value (an input on line 15) by one psi. The vent is fully closed whenever the tank internal pressure falls to less than PLIFT.

\subsection{HEAT TRANSFER FROM GAS TO TANK}

Heat transfer from contained gas to exposed surfaces inside the tank is computed at each time step. Surfaces modeled include:

- Concrete dome

- Steel liner and internal structures

- Exposed sludge (waste) surface

- Solvent pool surface.

The heat flux at each surface is computed as the sum of convection and radiation:

$$
w=\left(h_{c}+h_{r}\right)(T g-T s)
$$

where

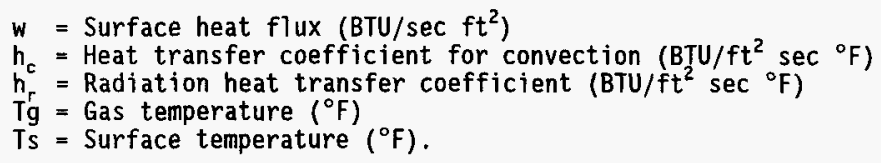

The total heat loss rate is calculated by summing the product of flux times area:

$$
\text { heat loss rate }=\sum_{i=1}^{i=4} W_{i} \cdot A_{i}
$$

Surface temperatures are computed as a function of time accounting for heat absorption. For steel and organic solvent, it was assumed that heat transport within the material was rapid enough to maintain temperature uniform with respect to depth (distance perpendicular to surface). For concrete and sludge, conduction away from the surface was calculated by dividing the solid into a number (typically 40) of one-dimensional nodes. Transient conduction from node to node was predicted by means of an explicit energy transport calculation in each node, at each time step.

Details of the heat transport calculations are described as follows. 


\subsubsection{Heat Transport to Steel Structures}

Heat transport rate from gas to steel structures by convection was computed by:

$$
Q_{c}=h_{c} A_{s}(T g-T s)
$$

where

$Q_{c}=$ Energy transfer rate due to convection (BTU/sec)

$h_{c}=$ Convection coefficient (BTU/sec ${ }^{\circ} \mathrm{F} \mathrm{ft}^{2}$ )

$A_{s}=$ Surface area of steel exposed to gas $\left(\mathrm{ft}^{2}\right)$

$\mathrm{T}_{\mathrm{g}}^{\mathrm{s}}=$ Temperature of gas $\left({ }^{\circ} \mathrm{F}\right)$

$\mathrm{T}_{\mathrm{s}}^{\mathrm{g}}=$ Temperature of steel $\left({ }^{\circ} \mathrm{F}\right)$.

The convection coefficient was computed by means of an empirical correlation developed for natural convection (McAdams, p. 172):

$$
\frac{h_{c} L}{k_{f}}=0.13[\mathrm{GrPr}]^{\frac{1}{3}}
$$

where

$$
\begin{aligned}
& h_{c}=\text { Convection coefficient (BTU/h }{ }^{\circ} \mathrm{F} \mathrm{ft}^{2} \text { ) } \\
& \mathrm{L}^{\mathrm{C}}=\text { Characteristic length of plate } \\
& \mathrm{K}_{\mathrm{f}}=\text { Thermal conduct ivity of gas at } \mathrm{film} \text { condition (BTU/h }{ }^{\circ} \mathrm{F} \mathrm{ft} \text { ) } \\
& \mathrm{Gr}=\text { Grashov number (dimensionless) } \\
& \mathrm{Pr}=\text { Prandtl number (dimensionless). }
\end{aligned}
$$

This correlation applies for turbulent flow (GrPr $\left.>10^{9}\right)$ along vertical surfaces.

Inserting the parameters that define the Grashov number, equat ion 13 , may be rearranged and solved for $h_{c}$ :

$$
h_{c}=0.13 K_{f}\left[\frac{P_{f} g \beta_{f} P r}{\mu_{f}^{2}}\right]^{\frac{1}{3}} \Delta T^{\frac{1}{3}}
$$

where

$$
\begin{aligned}
& \mathrm{P}=\text { Gas density }\left(1 \mathrm{~b} / \mathrm{ft}^{3}\right) \\
& \mathrm{g}=\text { Acceleration due to gravity }\left(\mathrm{ft} / \mathrm{h}^{2}\right) \\
& \beta=\text { Gas expansion coefficient }\left({ }^{\circ} \mathrm{F}^{-1}\right) \\
& \mu=\text { Gas viscosity (1b/ft } \mathrm{h}) \\
& \mathrm{f}=\text { Subscript denoting film conditions. }
\end{aligned}
$$


As a simplification, $h_{c}$ was expressed as a constant multiplied by $\Delta T^{1 / 3}$ :

$$
h_{c}=C_{y} \Delta T^{\frac{1}{3}}
$$

$C_{1}$ changes only slowly with temperature.

Inserting physical properties of air at $1 \mathrm{psig}$ and $142^{\circ} \mathrm{F}, \mathrm{C}_{1}$ was evaluated to be:

$$
C_{1}=0.22 \mathrm{BTU} / \mathrm{h}{ }^{\circ} \mathrm{F} \mathrm{ft}^{2} \text {. }
$$

The conditions cited above, $1 \mathrm{psig}$ and $142{ }^{\circ} \mathrm{F}$, were chosen to describe conditions early in a pool fire in tank $\mathrm{C}-103$, starting at an initial temperature of $103^{\circ} \mathrm{F}$ and an initial pressure of $14.5 \mathrm{psia}$. For higher temperature and pressure and conditions, a pressure of $30 \mathrm{psig}$ was judged to be a reasonable limit on the maximum contained pressures of interest. For physical properties of air at $30 \mathrm{psig}$ and $1267^{\circ} \mathrm{F}, \mathrm{C}$, was evaluated to be:

$$
C_{1}=0.318 \mathrm{BTU} / \mathrm{h}{ }^{\circ} \mathrm{F} \mathrm{ft}^{2} \text {. }
$$

Thus, for a postulated contained burn, $h_{c}$ increases with temperature, al though the change is not very large. In order to quant ify the increase in $C$, with temperature, a power law function based on absolute temperature was derived to fit the two values of $C$, described above. The resulting equation is:

$$
C_{1}=0.22\left(\frac{T_{R}}{601.4}\right)^{0.494}
$$

where

$T_{R}=$ Gas temperature $\left({ }^{\circ} R\right)$.

Using equar Tor 76 , equation 15 may be written as:

$$
h_{c}=0.22\left(\frac{T_{R}}{601.4}\right)^{0.494} \Delta T
$$


The head flux due to convection is added to radiation flux in line 2620:

$$
W S=W S+(T G A V-T S T L) \cdot 0.000061 * H T *[A B S(T G A V-T S T L)]^{0.33}
$$

Note that the constant in equatiof 71 is $0.22 / 3600$, and converts from $\mathrm{h}^{-1}$ to $\mathrm{sec}^{-1}$. The variable HT is the temperature factor in equat $601 \%$ and was calculated for the current time step in line 2326 . The variables listed in equation $T$ are defined as follows.

$$
\begin{aligned}
\text { WS } & \left.=\text { Heat flux to steel (BTU/s } \mathrm{ft}^{2}\right) \\
\text { TGAV } & =\text { Gas temperature }\left({ }^{\circ} \mathrm{R}\right) \\
\text { TSTL } & =\text { Steel temperature }\left({ }^{\circ} \mathrm{R}\right) .
\end{aligned}
$$

TGAV is calculated in line 2310 as the average of initial temperature for a time step and the temperature achieved after combustion and expansion. TG, in line 2310 is the gas temperature at the end of the previous time step, and TG is the most recent estimate that accounts for heatup and expansion, but not heat loss to surfaces. TGAV typically does not vary from $T G_{1}$ by more than $1^{\circ} \mathrm{F}$ because each problem is typically divided into 1,000 or more time steps. Thus, the gas heatup in any time step is small, so errors arising from an imprecise estimate of gas temperature during the heat transfer part of the cycle are also small.

Radiation heat flux from the gas to steel was computed from:

$$
\frac{q_{r}}{A}=\sigma E_{g}\left(T_{g}^{4}-T_{s}\right)^{4} E_{s}
$$

where

$$
\begin{aligned}
& \mathrm{q}_{r}=\text { Heat transfer rate due to radiation (BTU/h) } \\
& \mathrm{A}=\text { Surface area of steel }\left(\mathrm{ft}^{2}\right) \\
& \sigma=\text { Stefan-Boltzmann constant }\left(0.1718 \mathrm{E}-8 \mathrm{BTU} / \mathrm{h} \mathrm{ft}^{2}{ }^{\circ} \mathrm{R}^{4}\right) \\
& \mathrm{T}_{\mathrm{g}}=\text { Gas temperature }\left({ }^{\circ} \mathrm{R}\right) \\
& \mathrm{T}^{\mathrm{g}}=\text { Steel temperature ( } \\
& \left.\mathrm{C}_{\mathrm{s}} \mathrm{R}\right) \\
& \mathrm{E}_{\mathrm{g}}=\text { Emissivity of gas (dimensionless) } \\
& \mathrm{E}_{\mathrm{s}}=\text { Emissivity of steel (dimensionless). }
\end{aligned}
$$

Equat ion 18, from Perry (1950, p. 494), is a simplified expression of radiant heat transfer from a flame to its confinement barriers.

This expression is evaluated in line 2610:

$$
W S=S B * E G A S *\left(T_{G A V^{4}}-T_{S T L}^{4}\right) * E S T L
$$


where

$$
\begin{aligned}
& \text { WS = Heat flux to steel by radiation }\left(B T U / \mathrm{s}, \mathrm{ft}^{2}\right. \text { ) } \\
& \text { SB = Stefan-Boltzman constant (BTU/s } \mathrm{ft}^{2}{ }^{\circ} \mathrm{R}^{4} \text { ) } \\
& \text { EGAS = Emissivity of gas (dimensionless) } \\
& \text { ESTL = Emissivity of steel (dimensionless). }
\end{aligned}
$$

Note that SB, the Stefan-Boltzman constant is an input value (1 ine 60) that is divided by 3,600 in line 400 to convert from $\mathrm{h}^{-1}$ to $\mathrm{s}^{-1}$. EGAS and ESTL are inputs that are constants for a given problem. EGAS is an important parameter whose value depends on geometry, size scale (beam length), and the concentration of thermally radiating species in the confined gas. For the inefficient combustion associated with solvent pool fires, the airborne soot particles are predicted to be the dominant radiators. Means for estimating values of EGAS are described in detail in Attachment 1.

The change in steel temperature during a time step is predicted in line 2630:

$$
\text { TSTL = TSTL + WS * DT * STLAR / MCP }
$$

where

$$
\begin{aligned}
& \text { TSTL }=\text { Steel temperature }\left({ }^{\circ} \mathrm{R}\right) \\
& \text { WS }=\text { Total heat flux }\left(\mathrm{BTU} / \mathrm{s} \mathrm{ft}^{2}\right) \\
& \text { DT }=\text { Time step duration }(\mathrm{s}) \\
& \text { STLAR }=\text { Area of steel exposed to gas }\left(\mathrm{ft}^{2}\right) \\
& \text { MCP }=\text { Mass of steel * heat capacity. }
\end{aligned}
$$

Wasar 100.80 is based on an energy balance that equates heat transfer energy to the gain in sensible heat energy. STLAR is an input in 1 ine 20. MCP is computed in line 390:

$$
\text { MCP }=0.13 * \text { MASSTL }
$$

where

$$
\begin{array}{ll}
\text { MCP } & =\text { Product of mass and heat capacity } \\
\text { MASSTL } & =\text { Mass of steel (lb) } \\
0.13 & =\text { Heat capacity of steel (BTU/lb }{ }^{\circ} \mathrm{F} \text { ) } .
\end{array}
$$

The numerical value of MASSTL is an input on line 20.

The energy balance depicted in eavathor. 80 is based on the assumption that steel exposed to the gas is insulated, and does not lose heat to other structures. This assumption is conservative in the sense that steel heatup is overpredicted, and calculated heat loss rates will be underpredicted compared to the real case. In reality, much of the steel sheeting that lines waste tanks is backed by concrete. Heat loss to concrete in contact with the back side of a steel liners would reduce the rate of heatup of steel, a factor not accounted for in the mode1. 
The neglect of heat transfer from steel to concrete is judged to be relatively unimportant for large pool fire cases where the burn to oxygen extinguishment occurs in less than 7 minutes. During this short period, steel temperatures typically increase by $70^{\circ} \mathrm{F}$ or less whereas gas temperatures increase by $-700{ }^{\circ} \mathrm{F}$. Thus, the driving force for heat transfer (Tg-Ts) is not importantly affected by the increase in steel temperature.

For small fires, where a longer burn time could be predicted, steel heatup could be relatively more important. The effect would be an overestimate of gas temperature and therefore of pressurization caused by small fires. Since the overestimate of pressurization leads to conservative predictions of consequences of small pool fires, the neglect of heat loss from the liner to concrete would be important only if small fires were predicted to result in risks that were unacceptable.

\subsubsection{Heat Transport to Solvent Pool}

Heat transfer to the solvent pool by radiation and convection was accounted for. The calculations are made in a subroutine starting on 7 ine 2300 . At line 2320 , the heat flux attributable to radiation from bulk gas is calculated:

$$
W O=S B * E G A S *\left(T G A V^{4}-T_{O R G}^{4}\right) * E O R G
$$

where

$$
\begin{aligned}
& \text { WO }=\text { Heat flux at organic solvent surface (BTU/s } \mathrm{ft}^{2} \text { ) } \\
& \text { EORG }=\text { Emissivity of solvent (dimensionless) } \\
& \text { TORG }=\text { Pool temperature }\left({ }^{\circ} \mathrm{R}\right) .
\end{aligned}
$$
and 2330:

Convection is then calculated and added in 1ines $2325,2326,2327$,

$$
W O=W O+(T G A V-T O R G) * H
$$

where terms are as defined earlier.

In addition to radiation and convection from the bulk atmosphere, radiation from the flame is also added to the pool. This is done in 1 ine 2400 where the updated pool temperature is calculated.

$$
\text { TORG = TORG + }(W O * \text { ORGAR + WFLAME * BURNAR }) * D T / \text { MCPORG }
$$

where

$$
\begin{aligned}
& \text { TORG }=\text { Temperature of pool }\left({ }^{\circ} \mathrm{R}\right) \\
& \text { ORGAR }=\text { Surface area of pool }\left(\mathrm{ft}^{2}\right) \\
& \text { WFLAME }=\text { Radiation flux from } \mathrm{flame}\left(\mathrm{BTU} / \mathrm{s} \mathrm{ft}^{2}\right) \\
& \text { BURNAR }=\text { Inflamed area of poo }\left(\mathrm{ft}^{2}\right) \\
& \text { MCPORG }=\text { Product of mass and heat capacity }\left(\mathrm{BTU} /{ }^{\circ} \mathrm{F}\right) .
\end{aligned}
$$


Karacton 84 is based on a heat balance for a well-mixed pool. ORGAR and WFLAME are inputs (lines 80 and 20 , respectively). BURNAR is calculated in subroutine 1800 on the basis of initial inflamed area and fire spread velocity. MCPORG is calculated from input properties in line 360.

WFLAME is set equal to zero at the time of fire extinguishment. This is done at line 2761. This line is executed one time only on the basis of a flag (PRINTFLAG) whose value is set equal to two the first time oxygen falls below the inputted fire extinguishment level.

An upper limit on pool temperature is imposed at line 2410:

$$
2410 \text { IF TORG > BOIL THEN TORG }=\text { BOIL }
$$

BOIL is an input variable typically chosen as the normal boiling point of tridecane. The input value ( 1 ine 40 ) is in ${ }^{\circ} \mathrm{F}$, and is converted to ${ }^{\circ} \mathrm{R}$ at line 315 .

Pool mass, and consequently MCPORG, is a user guess or stipulation. Therefore, the predicted temperature of the pool is not likely to be an accurate valuation of temperature. Pool depth, a keyboard input is typically set at a value that leads to a desired pool temperature. For most problems, heat transfer to and from the pool is minor compared to other surfaces, so inaccuracies in pool temperature are not expected to have a major effect on predicted peak pressures and gas temperatures.

\subsubsection{Heat Transport to Concrete}

Heat transfer from bulk gas to concrete is calculated as the sum of that due to radiation and convection. This is done in lines 2350 and 2360 . Line 2350 computes the radiation flux:

$$
2350 W C=S B \cdot E G A S \cdot\left(T_{G A V^{4}}-T_{S C O N}^{4}\right) * E C O N
$$

where

$$
\begin{aligned}
& \text { WC } \left.=\text { Heat flux to concrete (BTU/s } \mathrm{ft}^{2}\right) \\
& \text { TSCON }=\text { Concrete surface temperature }\left({ }^{\circ} \mathrm{R}\right) \\
& \text { ECON }=\text { Concrete emissivity (dimensionless) } \\
& \text { EGAS }=\text { Gas emissivity } \\
& \text { TGAV }=\text { Gas temperature }\left({ }^{\circ} \mathrm{R}\right) .
\end{aligned}
$$

ECON, the emissivity of concrete, is an input (line 60).

The convective contribution to heat flux is added to radiation in line 2360 . 
WHC-SD-WM-CN-032, REV. 0

2360

$$
\begin{gathered}
W C=W C+(\text { TGAV }- \text { TSCON }) * 0.0000611 * H T \\
*[\text { ABS }(\text { TGAV }- \text { TSCON })]^{0.33}
\end{gathered}
$$

The convection term is identical to the formulation described in Section 5.4.1 that applies to heat transport to steel.

Concrete surface temperature is calculated at each time step by means of a one-dimensional slab model. Concrete walls are divided into a number of slices (nodes), and the change in temperature in each is computed for each time step. The algorithm used here was initially developed for an analys is of exothermic reactions in crust floating in tank SY-101 (Fox et al. 1991). Heat generation terms have been deleted because the materials analyzed herein do not exhibit exotherms on heating.

At the surface, heat flux is known from the heat transfer analysis described above (equat $/$ on 86 ). The average temperature in a node is assumed to occur at its midpoint. The surface temperature is computed by equating the surface flux to conduction in the first half of the first node:

$$
T_{s}=T_{1}+\frac{X W}{2 k}
$$

where

$$
\begin{aligned}
& T_{s}=\text { Surface temperature }\left({ }^{\circ} R\right) \\
& T_{1}=\text { Temperature at midpoint of first node } \\
& X^{1}=\text { Thickness of node }(\mathrm{ft}) \\
& W=\text { Heat flux on surface }\left(\mathrm{BTU} / \mathrm{s} \mathrm{ft}^{2}\right) \\
& \mathrm{K}=\text { Thermal conductivity of concrete (BTU/ } /{ }^{\circ} \mathrm{F} \mathrm{ft} \text { ). } \\
& \text { This calculational step is carried out in } 1 \text { ine } 2477 \text { : }
\end{aligned}
$$

$$
2477 \operatorname{TSCON}=\operatorname{TCON}(1)+X * W C /(2 * \mathrm{KCON})
$$

where

KCON = Thermal conductivity of concrete $\left(\mathrm{BTU} /{ }^{\circ} \mathrm{F} \mathrm{s} \mathrm{ft}\right\rangle$.

$X$, node thickness is computed by dividing the concrete wall thickness (DPTCON is an input on line 95) by the number of nodes selected (the number of nodes is an input on line 40). $\mathrm{KCON}$, in units of $\mathrm{BTU} / \mathrm{h}{ }^{\circ} \mathrm{F} \mathrm{ft}$, is an input on line 40. It is converted to $\mathrm{s}^{-1}$ units at line 480 . equation:

Temperatures in the nodes were computed from the energy conservation 
energy input rate = energy output rate + energy accumulation rate.

For the first node (the surface node), the increase in temperature is calculated as:

$$
\Delta T_{1}=\left[\frac{\alpha}{x^{2}}\left(2 T_{s}-3 T_{1}+T_{2}\right)\right] \Delta t
$$

where

$\Delta \mathrm{T}_{1}=$ Increase in temperature in node $1\left({ }^{\circ} \mathrm{R}\right)$

$\alpha=$ Thermal diffusivity of concrete $\left(\mathrm{ft}^{2} / \mathrm{s}\right)$

$T_{s}=$ Surface temperature $\left({ }^{\circ} R\right)$

$T_{2}=$ Temperature of node $2\left({ }^{\circ} R\right)$

$\Delta t=$ Length of time step (s).

Thermal diffusivity, $\alpha$, has the usual definition:

$$
\alpha=\frac{k}{\rho C_{p}}
$$

where

$$
\begin{aligned}
& k=\text { Thermal conductivity }\left(\mathrm{BTU} /{ }^{\circ} \mathrm{F} \mathrm{st}\right) \\
& \rho=\text { Material density }\left(\mathrm{lb} / \mathrm{ft}^{3}\right) \\
& \mathrm{C}_{\mathrm{p}}=\text { Heat capacity }\left(\mathrm{BTU} /{ }^{\circ} \mathrm{F}\right. \text { lb). }
\end{aligned}
$$

The term $\alpha \Delta t / X^{2}$ is a factor in equation 91 and all of the node heatup equations. This parameter is computed in tine 570 :

$$
570 \text { DOXCDT }=\text { DOXC } \cdot \text { DT }
$$

where

$$
\begin{aligned}
& \text { DOXCDT }=\alpha \Delta t / X^{2} \text { (dimensionless) } \\
& \mathrm{DOXC}=\alpha / \mathrm{X}^{2}\left(\mathrm{~s}^{-1}\right) \\
& \text { DT }=\Delta \mathrm{t}(\mathrm{s}) \text {. }
\end{aligned}
$$

DOXC is calculated from inputs in line 465 . The time step for this explicit calculational scheme is chosen so that: 
WHC-SD-WM-CN-032, REV. 0

$$
\frac{\alpha t}{x^{2}} \cong 0.1
$$

At this value of $\alpha t / X^{2}$, a heat wave entering one side of a node has time to just reach the other side of the node, resulting in an approximately linear distribution of temperature across the node. This can be seen from graphical results of the exact solution to the one-dimensional transient heat conduction equations as illustrated in Carslaw and Jaeger (1959 p. 101). The time step computed from exuation. 94 is printed on the screen at line 490 , and the user is asked to enter a rounded value close to the calculated value. The length of the calculated time step can be selected by the user by changing the value of $X$ (DPTCON), or the number of nodes (NN). Generally, the fires are too brief to permit heatup of all nodes, so only a portion of the concrete wall needs be modeled. Thus, very small time steps can be used if the depth of concrete modelled is set to a relatively small value.

For internal nodes, the energy balance equation (被) the following equation for temperature increase during a time step:

$$
\left.\Delta T(I)=\frac{\alpha}{x^{2}}\{[T(I-1)-2 T(I)+T(I+])]\right\} \Delta t
$$

where

$\Delta T(I)=$ Temperature increase for Ith node $\left({ }^{\circ} R\right)$

$\mathrm{T}(\mathrm{I})=$ Temperature of Ith node from previous time step $\left({ }^{\circ} \mathrm{R}\right)$

$\alpha, X, \Delta t=$ Are as defined in eatul $100 . \% 1$.

This calculation is carried out in a FOR-NEXT loop in lines 2490, 2500, and 2510 .

$$
2500 \operatorname{DELT}(\mathrm{I})=\operatorname{DOXCDT} *[\operatorname{TCON}(\mathrm{I}-1)-2 * \operatorname{TCON}(\mathrm{I})+\operatorname{TCON}(\mathrm{I}+1)]
$$

where

$\operatorname{DELT}(I)=$ Temperature increase in Ith node $\left({ }^{\circ} \mathrm{R}\right)$

$\operatorname{TCON}(I)=$ Temperature of Ith concrete node from previous step.

For the last node (NN), a boundary condition must be specified. This has been done by specifying the temperature of the ( $N N+1)$ th node equal to the initial concrete temperature (TSCONC). The effect is equivalent to maintaining the back side of the concrete in contact with a slab at constant temperature. The calculation is done at line 2520:

$$
2520 \operatorname{DELT}(\mathrm{NN})=\mathrm{DOXCDT} *[\mathrm{TCON}(\mathrm{NN}-1)-2 * \text { TCON (NN) + TSCONC }]
$$


where

TSCONC $=$ Initial concrete temperature $\left({ }^{\circ} \mathrm{R}\right)$.

The variable TSCONC is set equal to the initial concrete temperature in Iine 315 .

After the temperature changes have been calculated in all nodes, node temperatures are updated in line 2540 .

$$
2540 \operatorname{TCON}(I)=\operatorname{TCON}(I)+D E L T(I)
$$

The validity of this simple algorithm for predicting transient conduction in a slab was studied briefly in Fox (et al. 1991). Appendix $E$ from Fox (et al. 1991), where the study is documented, is appended to this calcnote as Attachment 2. As shown in the attachment, model predictions agreed well with the exact solution to the slab conduction problem.

\subsubsection{Heat Transport to Sludge}

Heat transport to sludge is treated similarly to heat transport to concrete. The calculations are carried out in a subroutine starting at line 2800 and ending at line 2940.

Since a common time step is used for all calculations, the node thickness for sludge was calculated to yield the same value of the parameter $\left(\alpha \mathrm{t} / \mathrm{x}^{2}\right)$ (see equation 94) for sludge as for concrete. This is done in line 425.

$$
425 X S L U D=X \cdot(\text { ASLUD } / A C O N)^{0.5}
$$

where

$$
\begin{aligned}
& X S L U D=\text { Node thickness for sludge }(\mathrm{ft}) \\
& X \quad=\text { Node thickness for concrete }(\mathrm{ft}) \\
& \text { ASLUD }=\text { Thermal diffusivity of sludge }\left(\mathrm{ft} / \mathrm{s}^{2}\right) \\
& \text { ACON }=\text { Thermal diffusivity for concrete }(\mathrm{ft} / \mathrm{s}) .
\end{aligned}
$$

The thermal diffusivity for concrete and sludge are calculated from input values of thermal conductivity, density, and heat capacity in lines 410 and 415 .

The area of sludge exposed to the tank atmosphere is calculated at line 305.

$$
305 \text { SLUDAR }=4418-\text { ORGAR }
$$


where

$$
\begin{aligned}
& \text { SLUDAR }=\text { Surface area of sludge }\left(\mathrm{ft}^{2}\right) \\
& \text { 4418 }=\text { Tank cross-sectional area }\left(\mathrm{ft}^{2}\right) \\
& \text { ORGAR }=\text { Solvent pool area }\left(\mathrm{ft}^{2}\right) .
\end{aligned}
$$

The numerical value of ORGAR is an input on line 80 . It is assumed that the tank is $75 \mathrm{ft}$ in diameter and that sludge occupies all of the cross-section except for the pool. This assumption is clearly incorrect for tanks which do not have the same diameter and waste configuration, so the equation on line 305 must be altered appropriately for other cases.

\subsection{CHANGE IN GAS TEMPERATURE DUE TO HEAT TRANSFER}

The change in gas temperature during a time step is computed in a subroutine starting at 1 ine 2700 and ending at line 2790 . The energy transferred is summed in line 2710:

$$
\begin{gathered}
2710 \text { HEATTX }=\text { WO * ORGAR + WC * CONAR + WS + STLAR } \\
\text { + WSLUD * SLUDAR + WFLAME * BURNAR }
\end{gathered}
$$

where

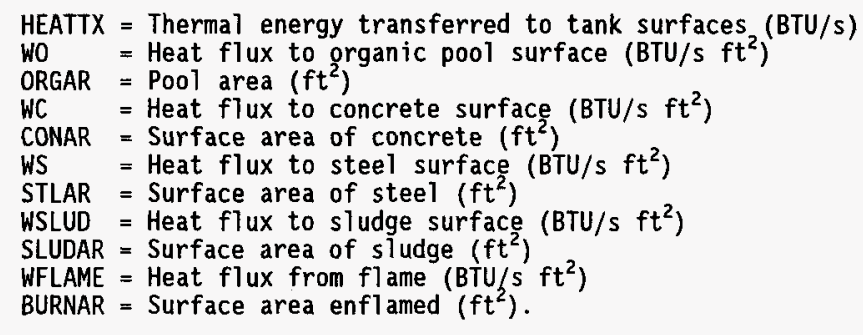

The heat transfer rate calculated in line 2710 is then used to calculate a change in gas temperature for a constant volume process.

$$
2720 \text { HEATTX = HEATTX * DT / MCV }
$$

where

$$
\begin{aligned}
& \text { HEATTX }=\text { Temperature change }\left({ }^{\circ} \mathrm{R}\right) \\
& \begin{aligned}
\text { DT } & =\text { Time step }(\mathrm{S}) \\
\text { MCV } & =\text { Moles of gas * mean heat capacity at constant volume }\left(\mathrm{BTU} /{ }^{\circ} \mathrm{R}\right) .
\end{aligned}
\end{aligned}
$$


WHC-SD-WM-CN-032, REV. 0

Gas temperature is updated in line 2730.

$$
2730 \text { TG }=\text { TG - HEATTX }
$$

where

$\mathrm{TG}=$ Gas temperature $\left({ }^{\circ} \mathrm{R}\right)$.

Gas pressure is then computed by means of the ideal gas 1 aw in line 2735 .

$$
2735 \text { P2 }=\text { MTOT * TG * ROV }
$$

where

$$
\begin{aligned}
& \text { P2 = Gas pressure (psia) } \\
& \text { MTOT = Total moles of contained gas (lb mols) } \\
& \text { ROV = Gas constant / gas volume (psia/ }{ }^{\circ} \mathrm{R} \text { mol). }
\end{aligned}
$$

The variable ROV is computed from inputs at 1 ine 380 .

\section{6 BURN RATE VERSUS OXYGEN CONCENTRATION}

As noted in Sections 5.1 and 5.2, the specific burn rate, MDOTB, has been assumed to remain constant. The approximate constancy of burn rate in the face of decreasing oxygen concentrations is consistent with large scale test results. Jordan and Linder (1983) state: "The burning rate was nearly constant during each experiment although the oxygen concentration was decreasing." Likewise, Malet (et a1.) state: "... and shows that the combustion rate can be considered like constant in first approximation."

Recent information provided by Dr. C. Beyler of Hughes Associates, Inc., indicates that burning rate decreases with oxygen concentration. The data provided by Beyler is shown in Figure 5-1. The data are from small scale tests and may not accurately apply to the large fires of interest to waste tanks. Nevertheless, in order to evaluate the potential impact of a variable burn rate, the code was modified to compute specific burn rate as a function of oxygen concentration.

As noted from Figure 5-1, the normalized burn rate decreases from 1.0 at $21 \% \mathrm{O}_{2}$ to a projected normalized rate of 0.125 at an oxygen concentration of $12 \%$. This straight 1 ine function was used as follows.

At the beginning of subroutine 1800 , a burning rate factor is computed. 
WHC-SD-WM-CN-032, REV. 0

Figure 5-1. Normalized Burn Rate Versus Oxygen Concentration.

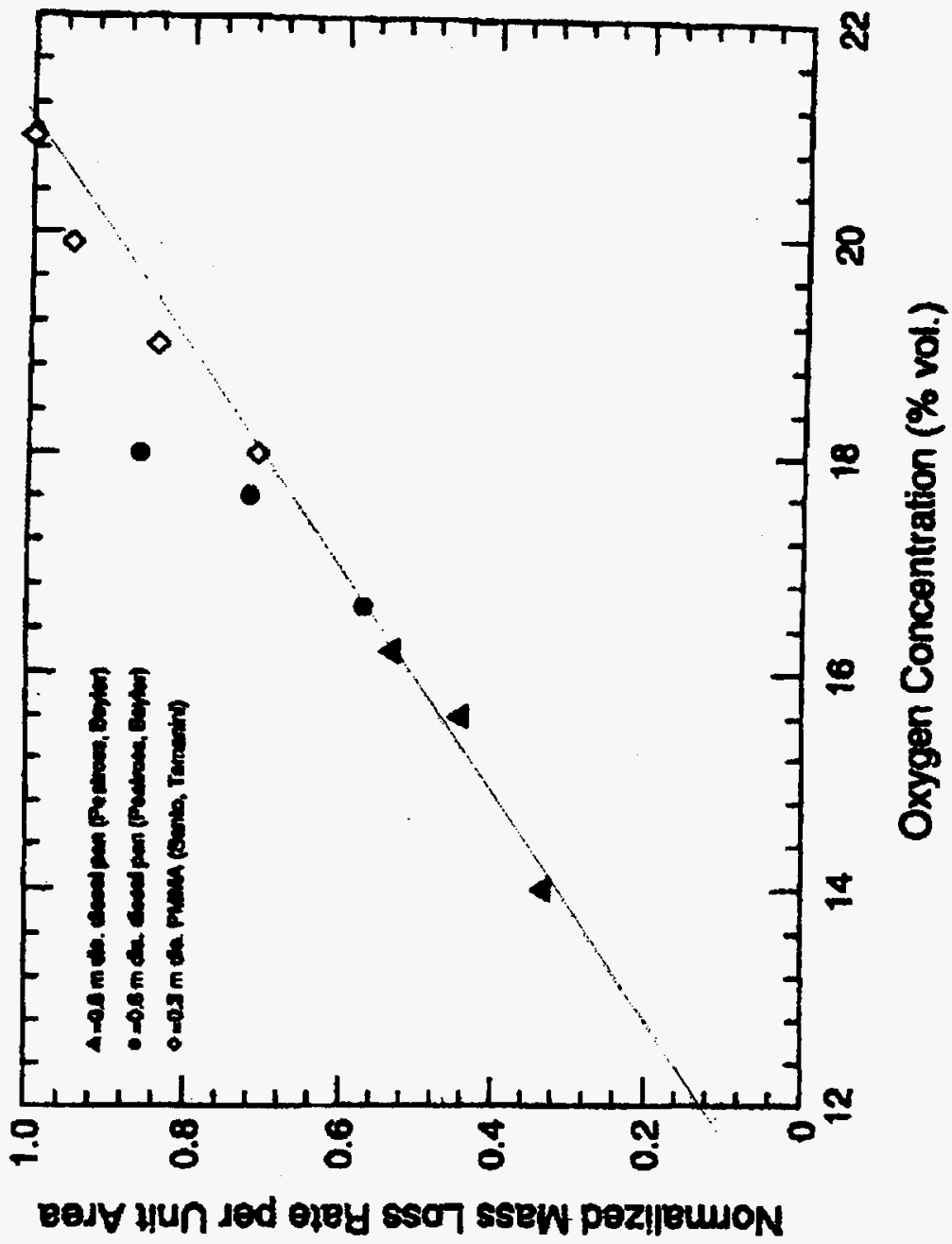


OXFACT is a multiplier of the input value of burn rate, MDOTB. The burn rate equation at line 1820 is then modified to include OXFACT.

$$
1820 \text { BRATE }=\text { BURNAR } \bullet \text { MDOTB } \bullet \text { OXFACT }
$$

The version of the code that includes the oxygen rate factor is called POOLFIRE. 4 to differentiate it from the original version, POOLFIRE.3.

\subsection{LISTING OF BASIC PROGRAMS}

This section contains printouts of both versions of the basic program used to analyze solvent pool fires in Hanford Site waste tanks.

\subsection{LISTING OF POOLFIRE.3}

Poolfire. 3 , the program version that treats burning rate $\left(\mathrm{kg} / \mathrm{min} \mathrm{m}^{2}\right)$ as a constant, is listed in the following seven pages. The input data shown on lines 15 through 96 apply to a large single-shell tank with an upper limit gas volume.

\subsection{LISTING OF POOLFIRE.4}

Poolfire.4, the program version that treats burning rate as a variable depending on oxygen concentration, is listed on the seven pages following the listing of Poolfire.4. Input data shown on lines 15 through 96 are the same as shown for Poolfire.3 except that the initial value of MDOTB (on line 20) is given a value of $3.0 \mathrm{~kg} / \mathrm{m}^{2}$ min. This initial value is lowered linearly with oxygen concentration. At the extinguishment level of 0.13 mole fraction the burning rate would be calculated to be:

$$
\begin{aligned}
\text { OXFACT } & =9.72 * 0.13-1.04=0.2236 \\
\text { MDOTB } & =0.2236(3)=0.67 \mathrm{~kg} / \mathrm{m}^{2} \mathrm{~min}
\end{aligned}
$$


WHC-SD-WM-CN-032, REV. 0

This page intentionally left blank. 
10 CLS

11 REM

12 REM

13 REM

14 REM

15 DATA

16 READ

20 DATA

30 READ

31 REM

$10.73,60$
$R$

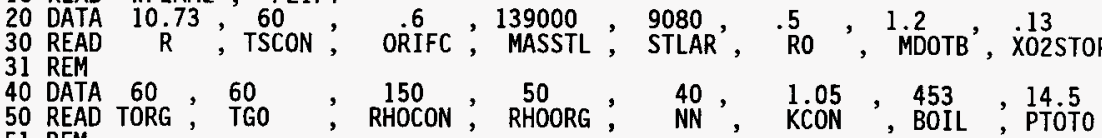

50 READ TORG， TGO ;

51 REM

60 DATA

70 READ

THIS PROGRAM ANALYZES ORGANIC POOL FIRES IN TANK C-103

THIS PROGRAM IS CALLED POOLFIRE. 3

71 REM

$5.02,7.4$

WFLAME , PLIFT

$.1713 \mathrm{E}-8$

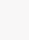
$, 1.00,0.90,0.90,0.90, .0615,24.7$

80 DATA $14140 ;$ READ DELH ; PWATO 1170000,$4885 ;$
90 GVOL

91 REM

95 DATA $60, \quad 0.27,120, .5,0.9,38,55$

96 READ TSLUD ;, KSLUD ; RHOSLUD', CPSLUD ; ESLUD ; DPTCON; TGOUT

99 REM

100 DIM TCON(NN), YCON(NN), DELT(NN), TCONF(NN), TSLUD(NN), YSLUD(NN), TSLUDF (NN)

120 PRINT "THIS'PROGRAM IS CALLED" POOLFIRE.'3"

122 PRINT

124 PRINT

125 PRINT

"THIS PROGRAM ANALYZES TEMPERATURE AND PRESSURE TRANSIENTS IN C-103"

126 PRINT "THIS VERSION COMPUTES INFLOW OF AIR AFTER FIREOUT"

150 PRINTFL $A G=0$

160 PLIFT=PLIFT+PTOTO

201 PRINT

210 INPUT "WHAT IS THE EQUIVALENT VENT ORIFICE DIAMETER IN INCHES";DORF

211 PRINT

215 INPUT "WHAT IS THE EQUIV. ORIFICE DIA. FOR SALTWELL IN INCHES";DSALT

216 PRINT

217 SAREA $=.7854^{\star}(\text { DSALT } / 12)^{\wedge} 2$

220 INPUT "TOTAL TIME FOR COMPUTATON TO CONTINUE--SEC";TIMTOT

221 PRINT" "

230 INPUT "THICKNESS OF ORGANIC POOL--FEET";DPT

231 PRINT" "

240 INPUT " ASSUMED SPREAD VELOCITY OF FIRE OVER POOL-IN CM/SEC ";SPREADV

241 PRINT" "

251 PRINT" "

$300 \mathrm{E} 12=1 /(1 / \mathrm{ECON}+1 / \mathrm{EORG}-1)$

305 SLUDAR $=4418-0 R$ RAR

$310 \mathrm{~T}=459.6+\mathrm{TGO}: \mathrm{BURNR}=(\text { ORGAR } / 3.1416)^{\wedge} .5$

315 TORGC $=T O R G+459.6: T S C O N C=T S C O N+459.6: T S S L U D C=T S L U D+459.6: B O I L=B O I L+459.6$

$320 \mathrm{MH} 20=\mathrm{PWATO} * \mathrm{GVOL} /(\mathrm{R} * \mathrm{~T})$

330 MTOT $=$ PTOTO*GVOL $(R * T):$ MTOTO $=$ MTOT

340 MN2 $=.79 *($ MTOT $-M H 2 O)$

$350 \mathrm{MO2}=.21 *($ MTOT-MH2O)

$351 \mathrm{MO20}=\mathrm{M02}$

$355 \mathrm{MCO} 2=0$

360 MCPORG $=0 R G A R * D P T * R H 00 R G * C P O R G$

$365 \times 02=M 02 / M T O T$

370 FOLD $=0$

$380 \mathrm{ROV}=\mathrm{R} / \mathrm{GVOL}$

385 FAREA $0=.7854 *(\text { DORF } / 12)^{\wedge} 2$

$390 \mathrm{MCP}=.13 *$ MASSTL 
WHC-SD-WM-CN-032, REV. 0

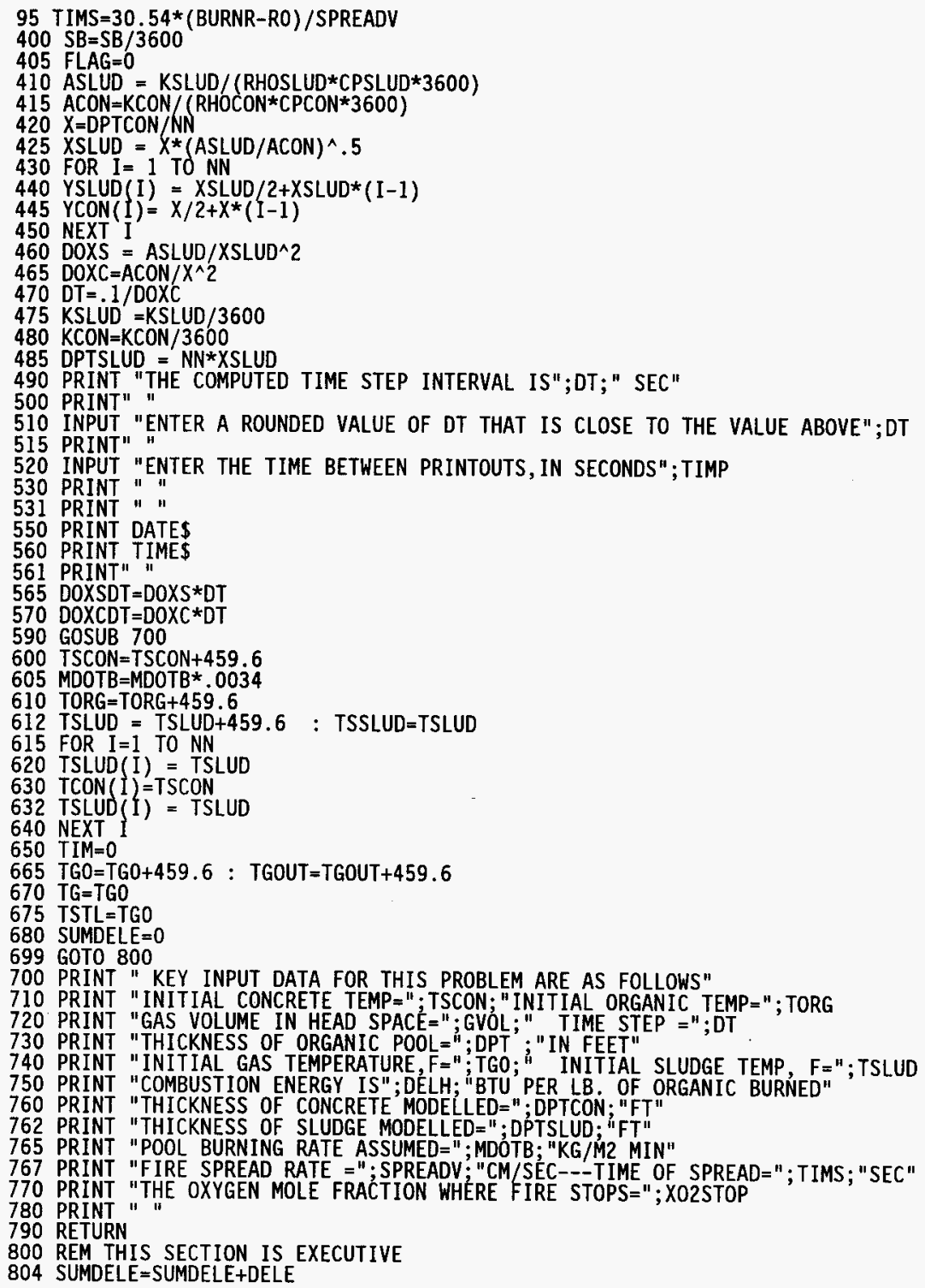


WHC-SD-WM-CN-032, REV. 0

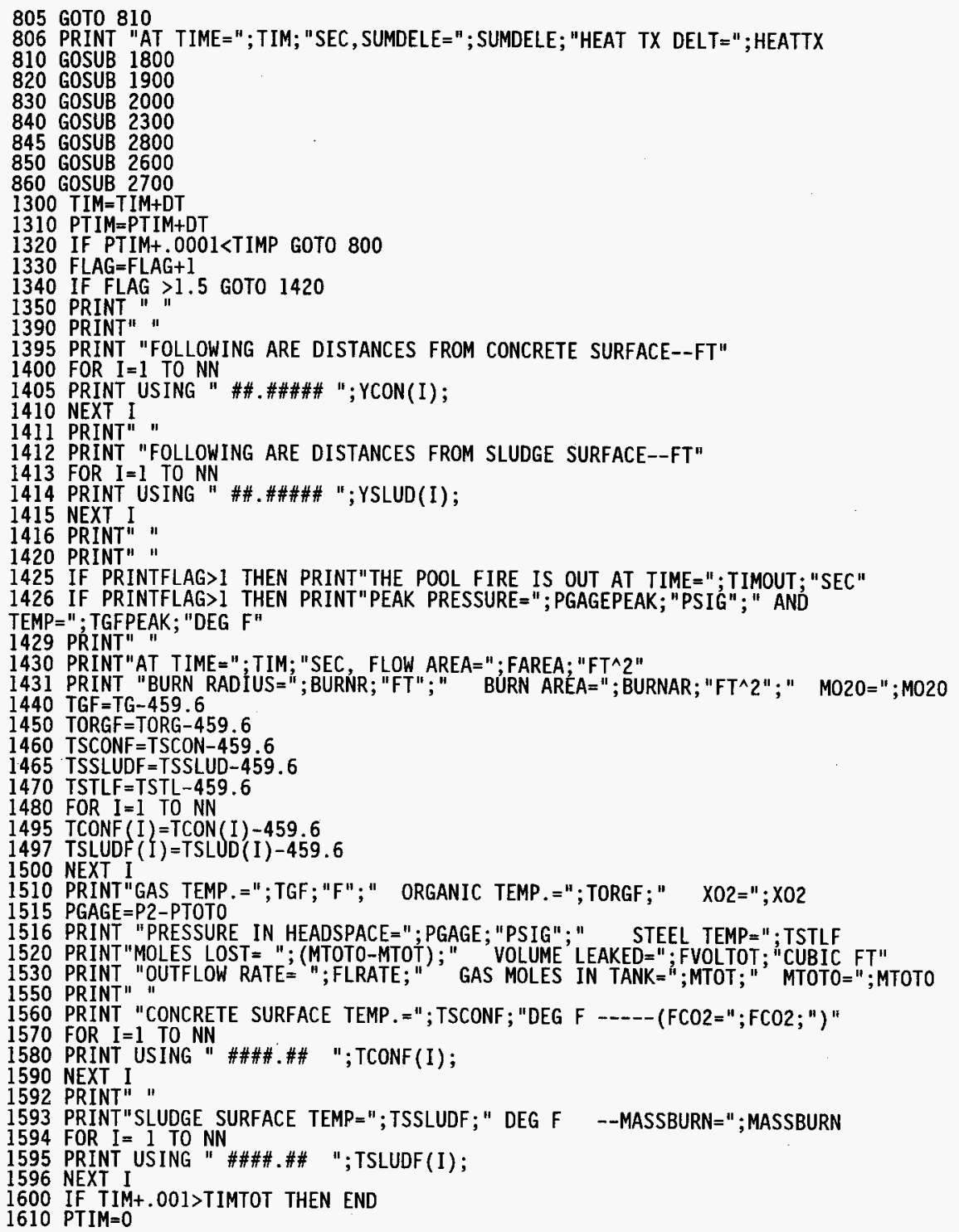




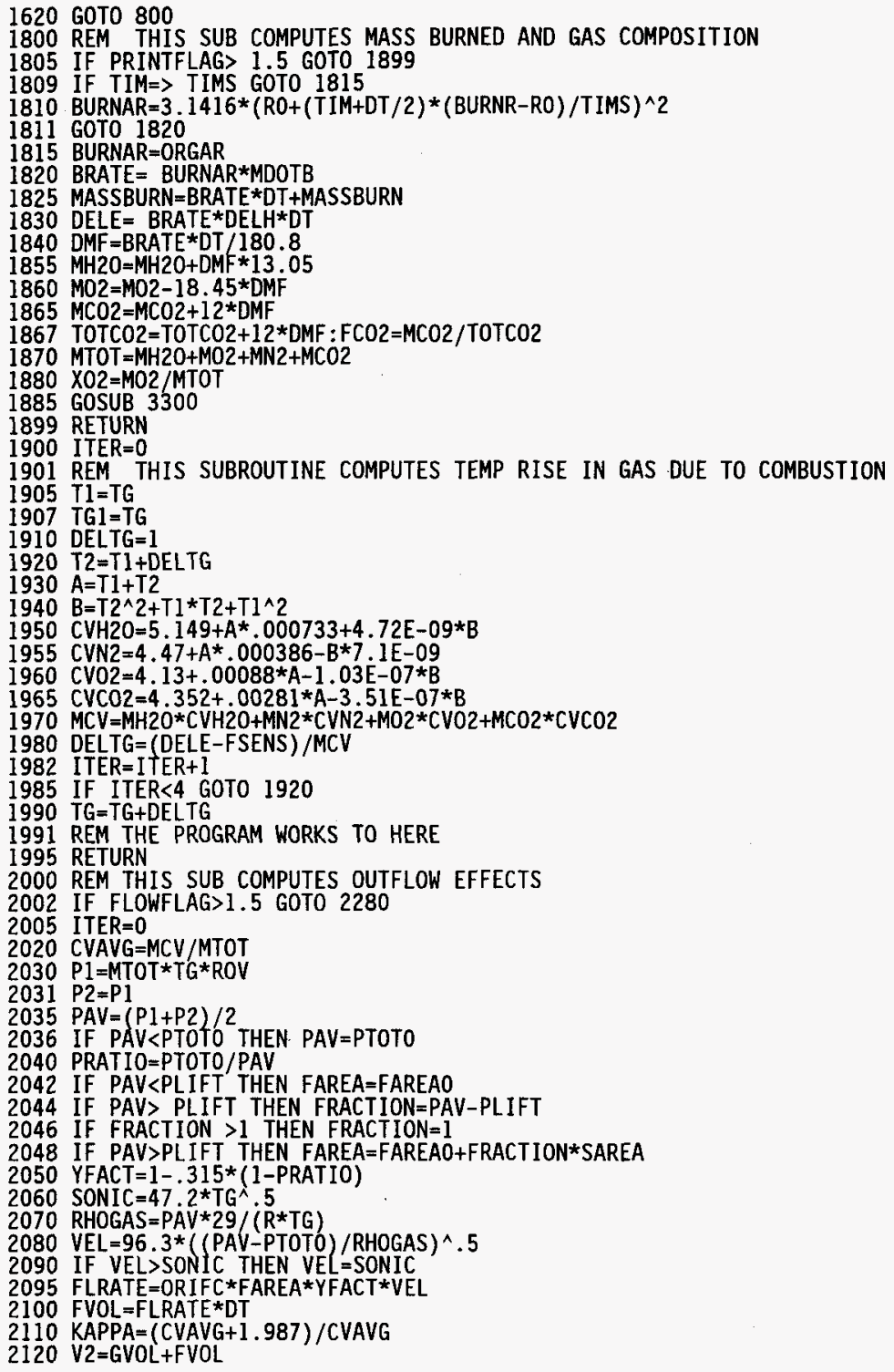




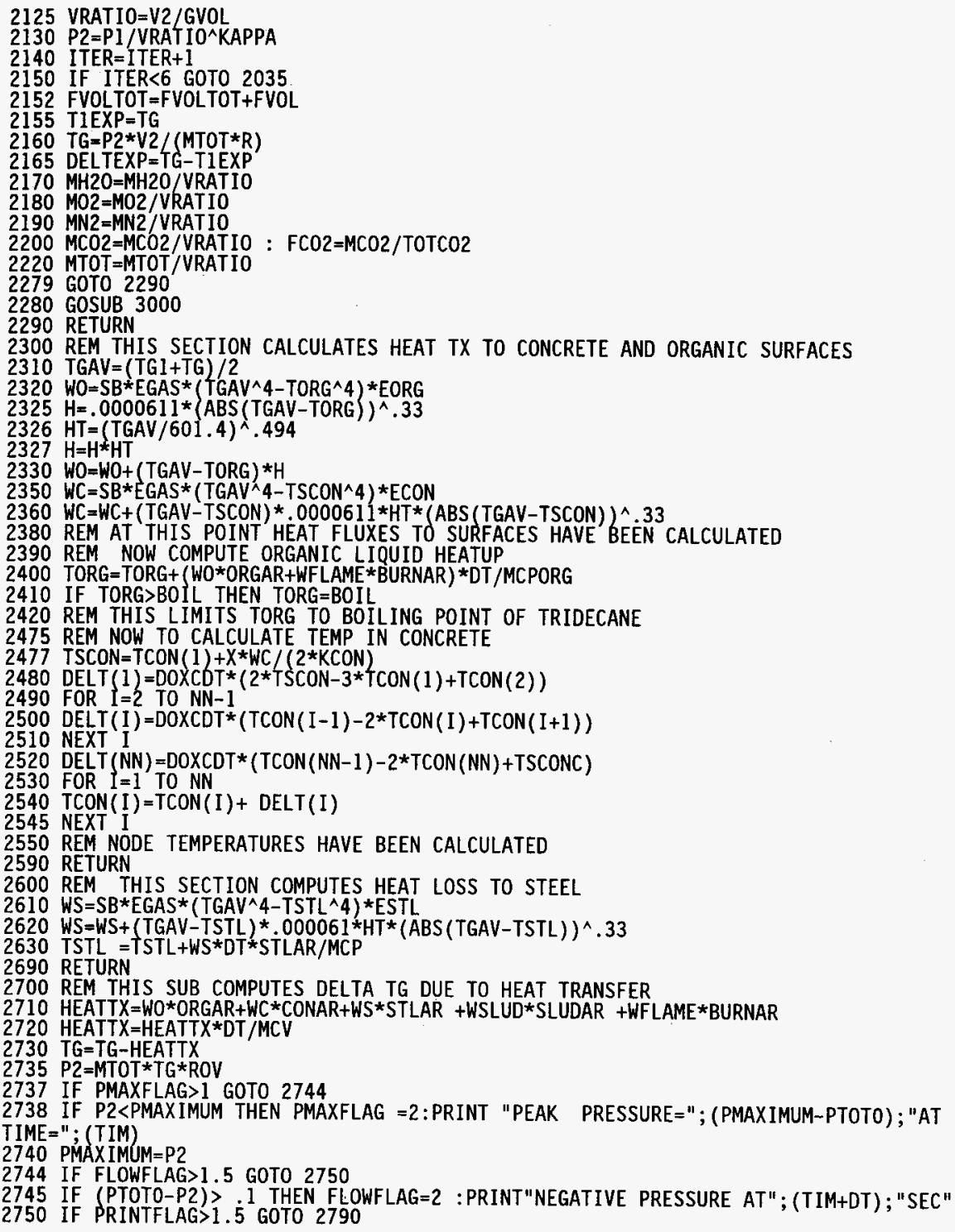




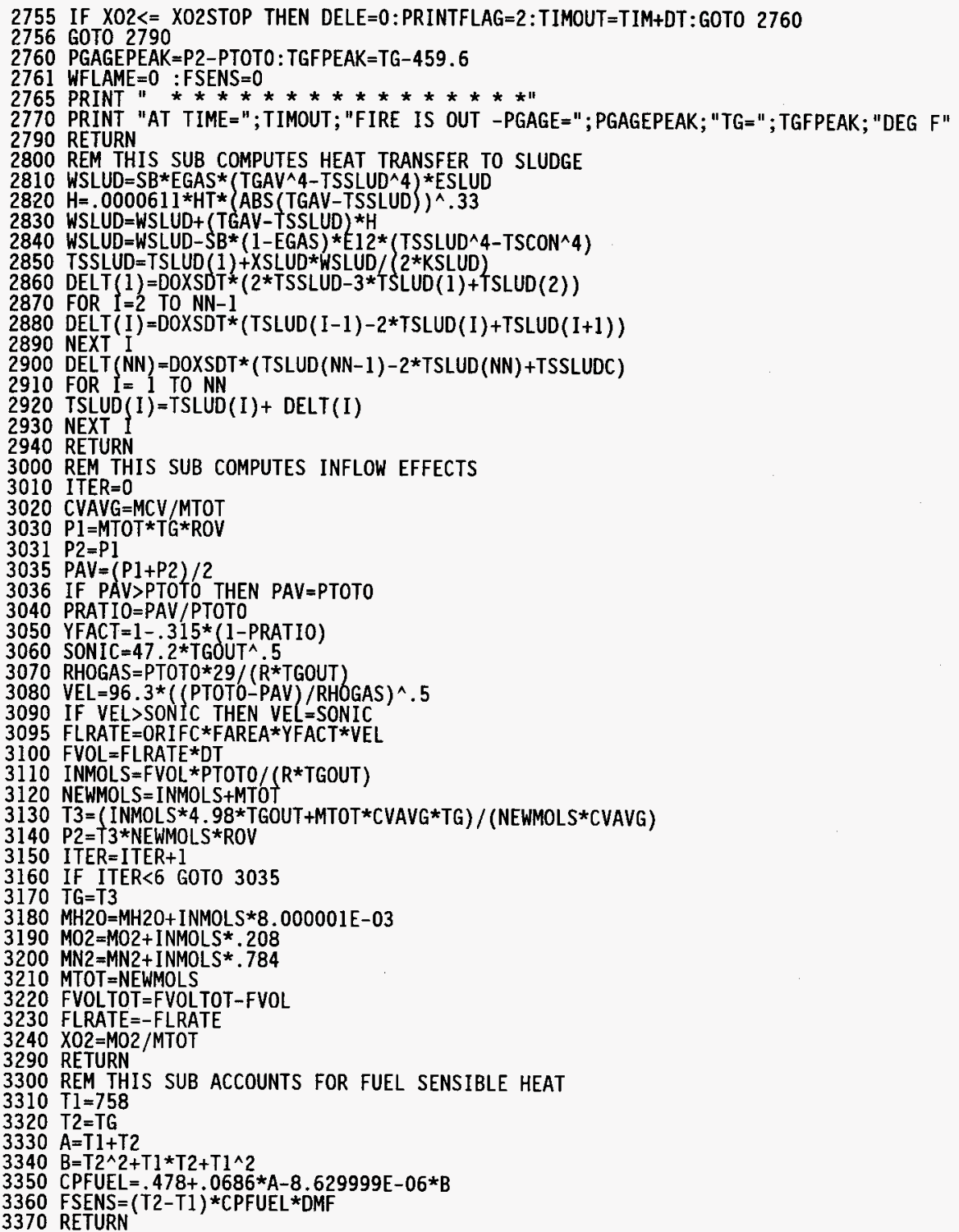




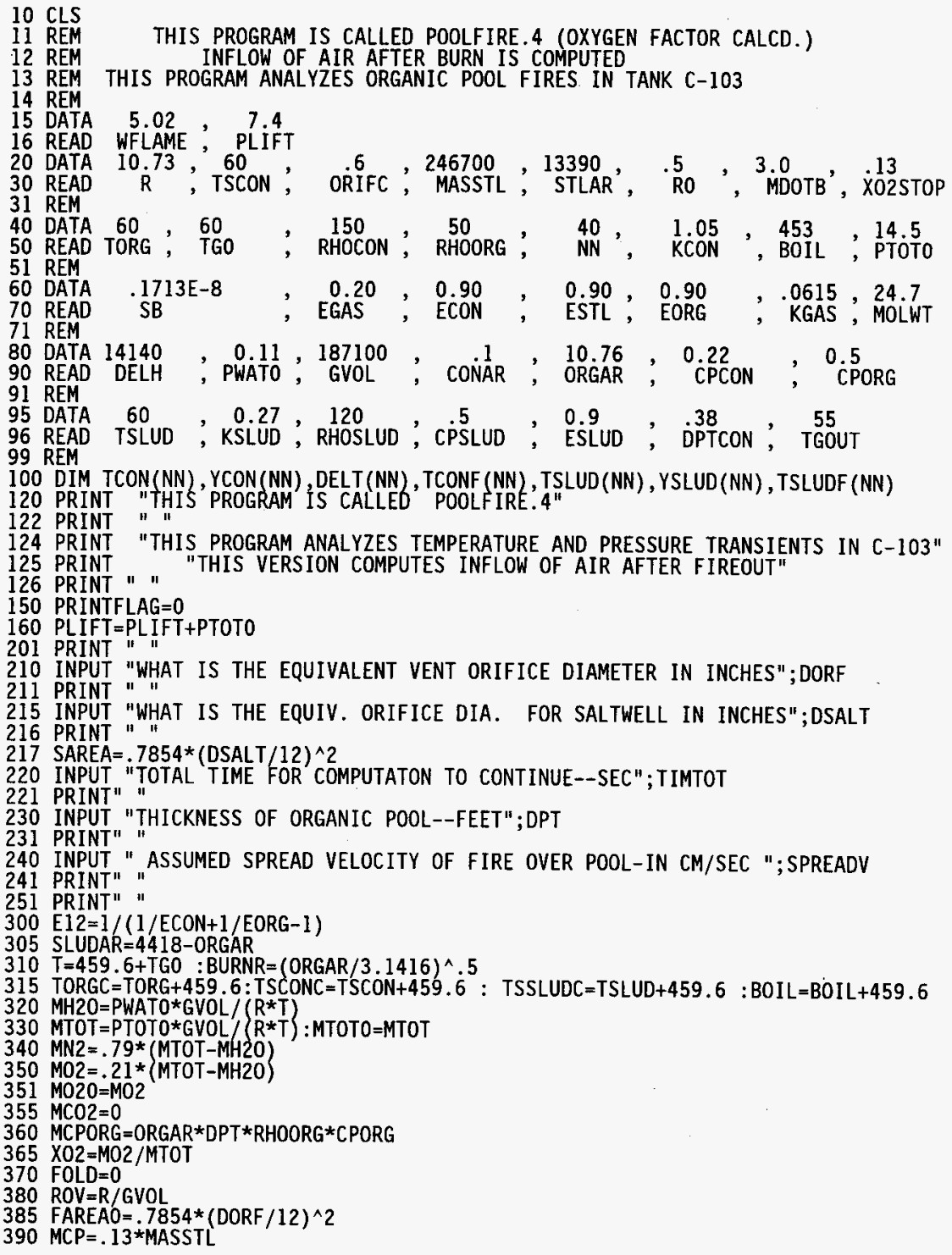


WHC-SD-WM-CN-032, REV. 0

395 TIMS $=30.54$ * (BURNR-RO) $/$ SPREADV

$400 \mathrm{SB}=\mathrm{SB} / 3600$

405 FLAG $=0$

410 ASLUD $=$ KSLUD $/($ RHOSLUD*CPSLUD $* 3600)$

415 ACON $=K C O N /(R H O C O N * C P C O N * 3600)$

$420 \mathrm{X}=\mathrm{DPTCON} / \mathrm{NN}$

$425 X S L U D=X^{\star}($ ASLUD $/ A C O N) \wedge .5$

430 FOR $I=1$ TO NN

440 YSLUD $(1)=X S L U D / 2+X S L U D *(I-1)$

$445 Y C O N(1)=X / 2+X *(I-1)$

450 NEXT I

460 DOXS = ASLUD $/ X S L U D^{\wedge} 2$

$465 \mathrm{DOXC}=\mathrm{ACON} / \mathrm{X}^{\wedge} 2$

$470 \mathrm{DT}=.1 / \mathrm{DOXC}$

$475 \mathrm{KSLUD}=\mathrm{KSLUD} / 3600$

$480 \mathrm{KCON}=\mathrm{KCON} / 3600$

485 DPTSLUD $=N N * X S L U D$

490 PRINT "THE COMPUTED TIME STEP INTERVAL IS"; DT; "SEC"

500 PRINT" "

510 INPUT "ENTER A ROUNDED VALUE OF DT THAT IS CLOSE TO THE VALUE ABOVE";DT

515 PRINT" "

520 INPUT "ENTER THE TIME BETWEEN PRINTOUTS, IN SECONDS";TIMP

530 PRINT " "

531 PRINT " "

550 PRINT DATE\$

560 PRINT TIMES

561 PRINT" "

565 DOXSDT $=\mathrm{DOXS} * \mathrm{DT}$

570 DOXCDT $=D 0 X C * D T$

590 GOSUB 700

600 TSCON $=$ TSCON +459.6

605 MDOTB $=$ MDOTB*.0034

610 TORG $=$ TORG +459.6

612 TSLUD $=$ TSLUD+459.6 : TSSLUD=TSLUD

615 FOR I $=1$ TO NN

620 TSLUD(I) $=$ TSLUD

$630 \operatorname{TCON}(I)=\operatorname{TSCON}$

632 TSLUD (I) $=$ TSLUD

640 NEXT I

650 TIM $=0$

665 TGO $=$ TG0 $+459.6: T G O U T=T G O U T+459.6$

$670 \mathrm{TG}=\mathrm{TGO}$

675 TSTL=TGO

680 SUMDELE $=0$

699 GOTO 800

700 PRINT "KEY INPUT DATA FOR THIS PROBLEM ARE AS FOLLOWS"

710 PRINT "INITIAL CONCRETE TEMP="; TSCON; "INITIAL ORGANIC TEMP="; TORG

720 PRINT "GAS VOLUME IN HEAD SPACE=";GVOL;" TIME STEP ="; DT

730 PRINT "THICKNESS OF ORGANIC POOL=";DPT'; "IN FEET"

740 PRINT "INITIAL GAS TEMPERATURE, $F="$ "TGO;" INITIAL SLUDGE TEMP, $F="$;TSLUD

750 PRINT "COMBUSTION ENERGY IS"; DELH; "BTU PER LB. OF ORGANIC BURNED"

760 PRINT "THICKNESS OF CONCRETE MODELLED="; DPTCON; "FT"

762 PRINT "THICKNESS OF SLUDGE MODELLED=" :DPTSLUD; "FT"

765 PRINT "POOL BURNING RATE ASSUMED=";MDÓTB; "KG/M2 MIN"

767 PRINT "FIRE SPREAD RATE = "; SPREADV; "CM/SEC---TIME OF SPREAD=" ; TIMS; "SEC"

770 PRINT "THE OXYGEN MOLE FRACTION WHÉRE FIRE STOPS="; XO2STOP

780 PRINT " "

790 RETURN

800 REM THIS SECTION IS EXECUTIVE

804 SUMDELE $=$ SUMDELE+DELE 
WHC-SD-WM-CN-032, REV. 0

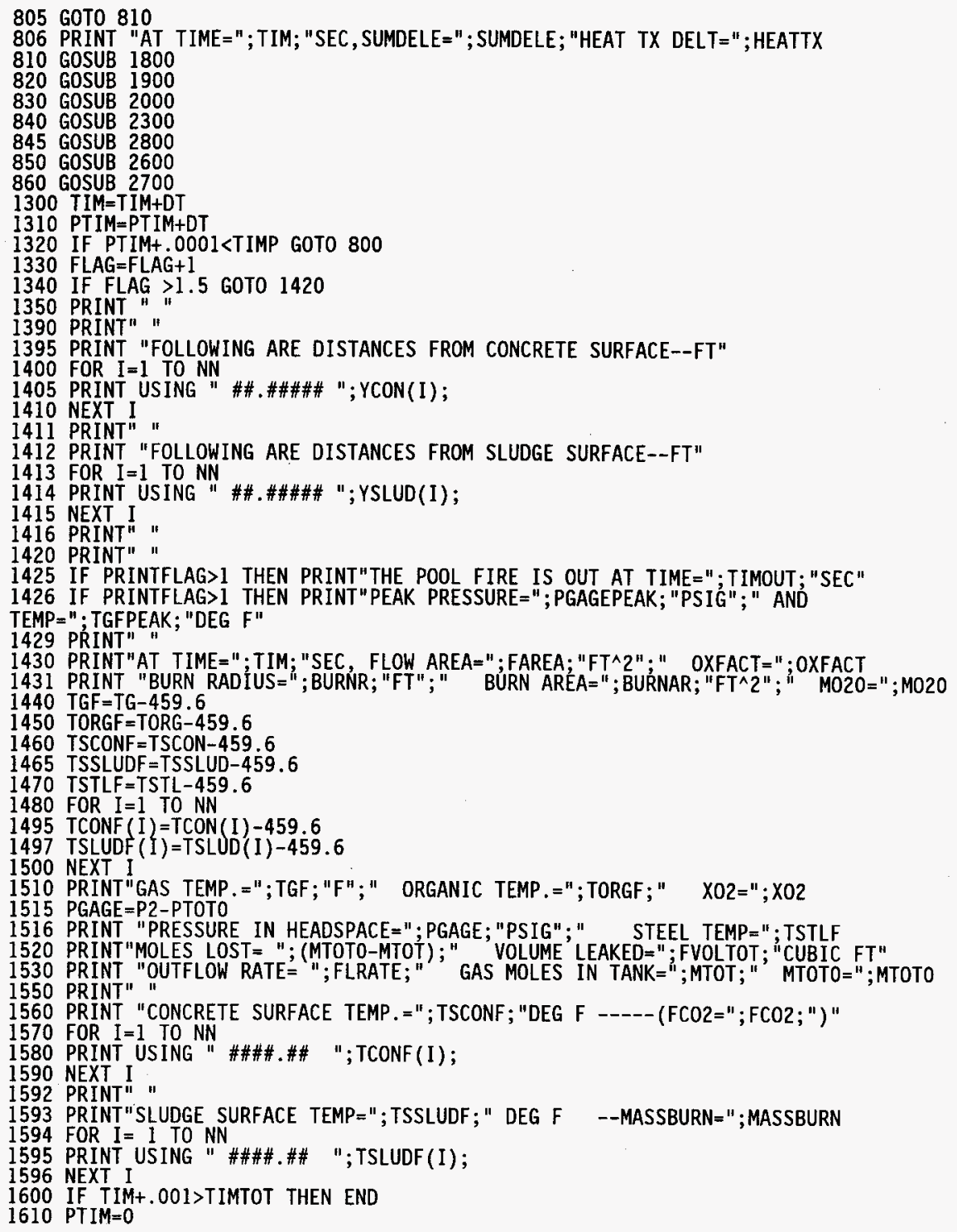




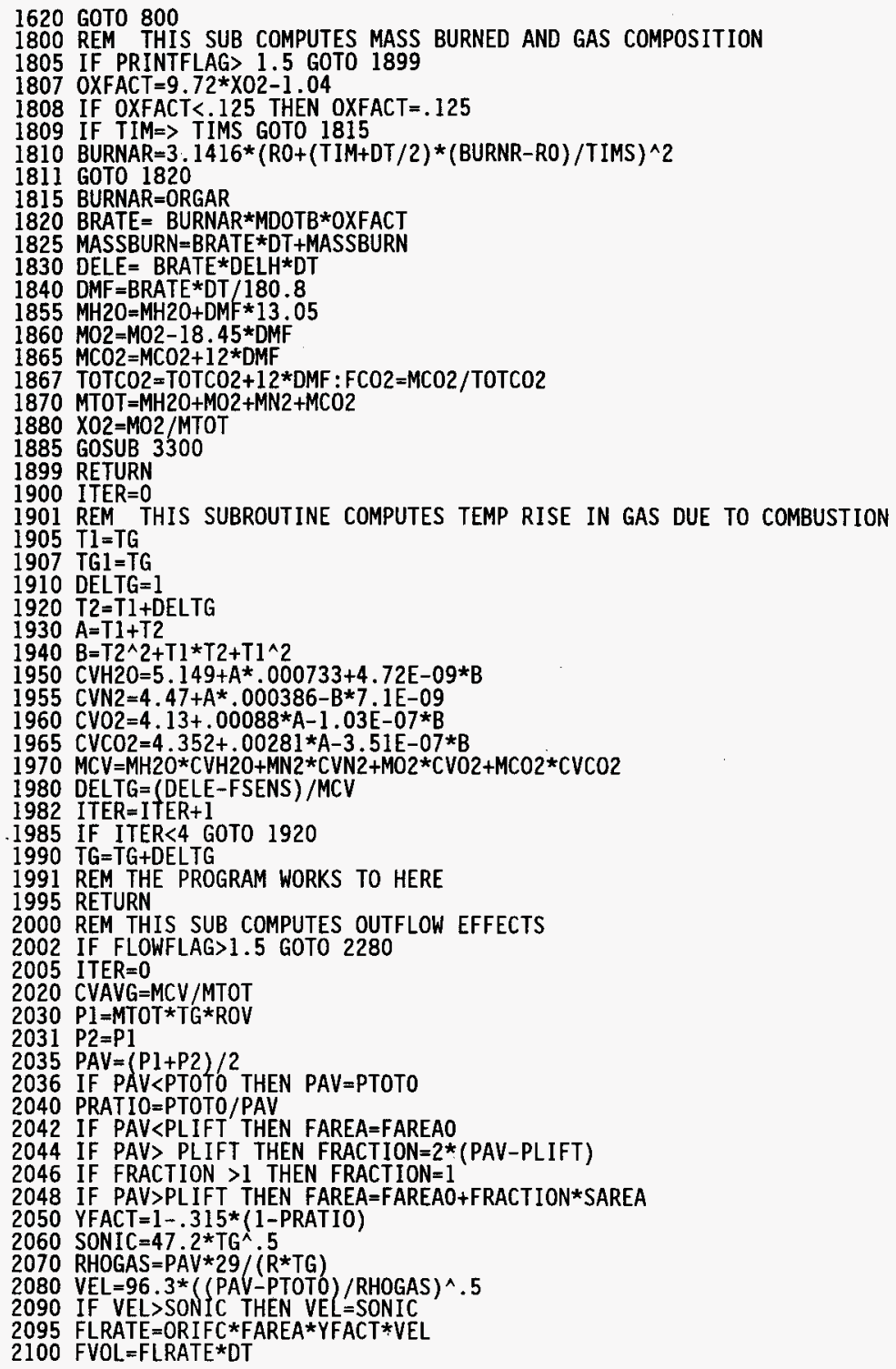


WHC-SD-WM-CN-032, REV. 0

$2110 \mathrm{KAPPA}=(\mathrm{CVAVG}+1.987) / \mathrm{CVAVG}$

$2120 \quad \mathrm{~V} 2=\mathrm{GVOL}+\mathrm{FVOL}$

2125 VRAT IO $=$ V $2 /$ GVOL

2130 P2=P1/VRATIOAKAPPA

2140 ITER $=$ ITER+1

2150 IF ITER<6 GOTO 2035

2152 FVOLTOT $=F V O L T O T+F V O L$

2155 TIEXP=TG

$2160 T G=P 2 * V 2 /(M T O T * R)$

2165 DELTEXP=TG-TIEXP

2170 MH20 $=$ MH2O /VRAT IO

$2180 \mathrm{M02}=\mathrm{M02} / \mathrm{VRATIO}$

2190 MN2 $=$ MN2 $/$ VRATIO

2200 MCO2=MCO2/VRATI0 : FCO2=MC02/TOTCO2

2220 MTOT $=$ MTOT $/$ VRATIO

2279 GOTO 2290

2280 GOSUB 3000

2290 RETURN

2300 REM THIS SECTION CALCULATES HEAT TX TO CONCRETE AND ORGANIC SURFACES

$2310 \mathrm{TGAV}=(\mathrm{TG} 1+\mathrm{TG}) / 2$

$2320 W O=S B \star E G A S^{\star}\left(T G A V^{\wedge} 4-T O R G^{\wedge} 4\right) * E O R G$

$2325 \mathrm{H}=.0000611^{*}(\mathrm{ABS}(\mathrm{TGAV}-\mathrm{TORG}))^{\wedge} .33$

$2326 \mathrm{HT}=(\mathrm{TGAV} / 601.4)^{\wedge} .494$

$2327 \mathrm{H}=\mathrm{H} * \mathrm{HT}$

$2330 W 0=W 0+(T G A V-T O R G) \star H$

$2350 W C=S B^{\star} E G A S^{\star}\left(T G A V^{\wedge} 4-T S C O N^{\wedge} 4\right)^{*} E C O N$

$2360 W C=W C+($ TGAV-TSCON) $* .0000611 * H T *$ (ABS $(T G A V-T S C O N)) \wedge .33$

2380 REM AT THIS POINT HEAT FLUXES TO SURFACES HAVE BEEN CALCULATED

2390 REM NOW COMPUTE ORGANIC LIQUID HEATUP

2400 TORG $=T O R G+(W O \star O R G A R+W F L A M E \star B U R N A R) * D T / M C P O R G$

2410 IF TORG $>B O I L$ THEN TORG $=B O I L$

2420 REM THIS LIMITS TORG TO BOILING POINT OF TRIDECANE

2475 REM NOW TO CALCULATE TEMP IN CONCRETE

$2477 T S C O N=T C O N(1)+X * W C /(2 * K C O N)$

$2480 \mathrm{DELT}(1)=\mathrm{DOXCDT} *(2 * T S C O N-3 * T \operatorname{CON}(1)+\operatorname{TCON}(2))$

2490 FOR I=2 TO NN-1

$2500 \operatorname{DELT}(\mathrm{I})=\mathrm{DOXCDT} *(\operatorname{TCON}(\mathrm{I}-1)-2 * \operatorname{TCON}(\mathrm{I})+\mathrm{TCON}(\mathrm{I}+1))$

2510 NEXT I

2520 DELT $(N N)=D O X C D T *(T C O N(N N-1)-2 * T C O N(N N)+T S C O N C)$

2530 FOR $I=1$ TO NN

$2540 \operatorname{TCON}(\mathrm{I})=\mathrm{TCON}(\mathrm{I})+\operatorname{DELT}(\mathrm{I})$

2545 NEXT I

2550 REM NODE TEMPERATURES HAVE BEEN CALCULATED

2590 RETURN

2600 REM THIS SECTION COMPUTES HEAT LOSS TO STEEL

$2610 W S=S B * E G A{ }^{*}\left(T G A V^{\wedge} 4-T S T L \wedge 4\right) * E S T L$

$2620 W S=W S+(T G A V-T S T L) * .000061 * H T *(A B S(T G A V-T S T L)) \wedge .33$

$2630 \mathrm{TSTL}=\mathrm{TSTL}+W S * D T * S T L A R / M C P$

2690 RETURN

2700 REM THIS SUB COMPUTES DELTA TG DUE TO HEAT TRANSFER

2710 HEATTX $=W O * O R G A R+W C * C O N A R+W S * S T L A R+W S L U D \star S L U D A R$ +WFLAME*BURNAR

2720 HEATTX $=$ HEATT $X \star D T / M C V$

2730 TG=TG-HEATTX

$2735 P 2=M T O T * T G * R O V$

2737 IF PMAXFLAG>1 GOTO 2744

2738 IF P2<PMAXIMUM THEN PMAXFLAG=2 :PRINT "PEAK PRESSURE ="; (PMAXIMUM-PTOTO);

"AT TIME $="$ "; (TIM)

2740 PMAXIMUMM=P2

2744 IF FLOWFLAG>1.5 GOTO 2750

2745 IF (PTOTO-P2)> .1 THEN FLOWFLAG=2 :PRINT "NEGATIVE PRESSURE AT"; (TIM+DT); "SEC" 
WHC-SD-WM-CN-032, REV. 0

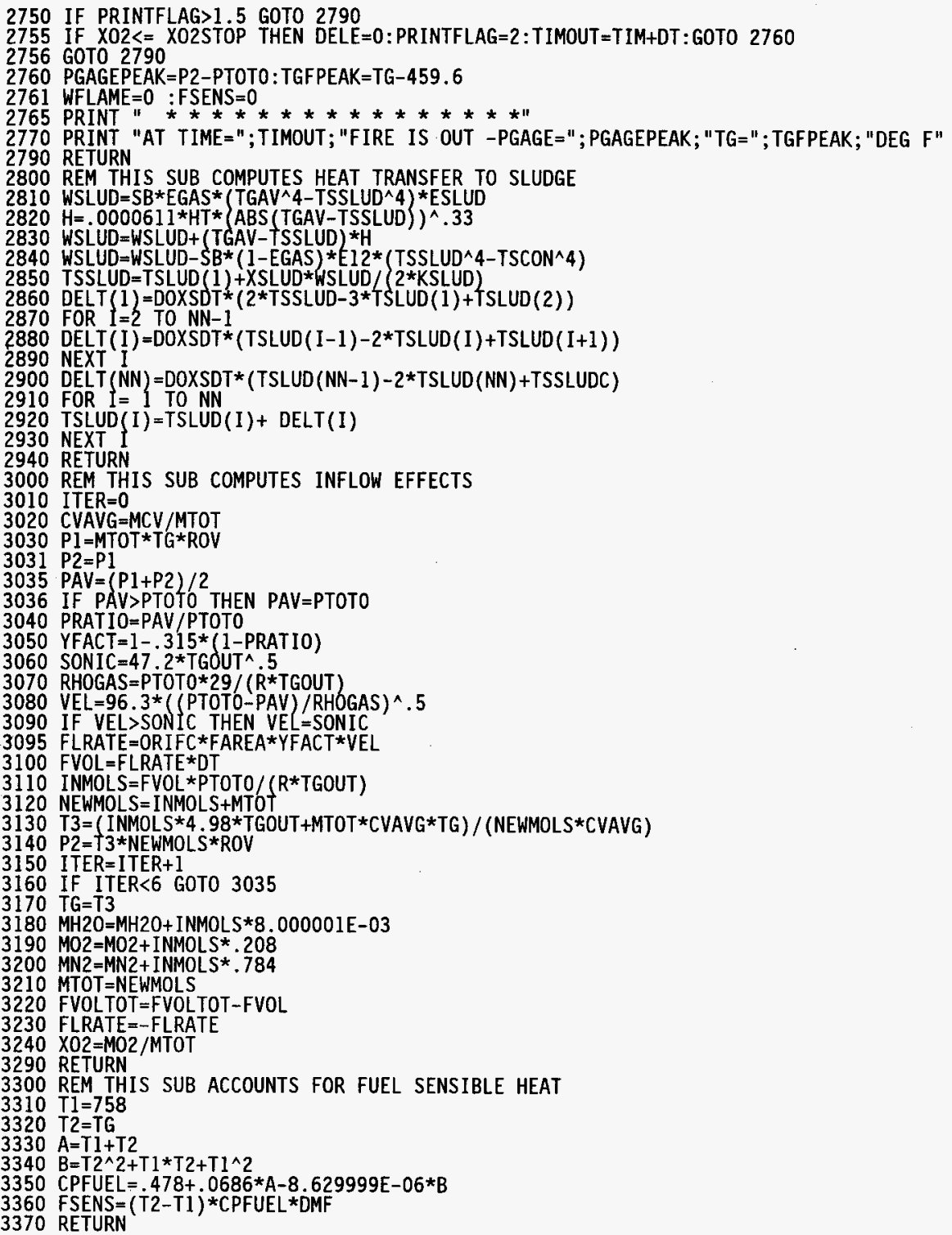


WHC-SD-WM-CN-032, REV. 0

\subsection{EXAMPLE ANALYSIS WITH POOLFIRE.3}

An example analysis of a pool fire in a large (l million gallon) SST is presented in this section. Key inputs are:

Vent Orifice Diameter

A vent orifice diameter of 3.75 in. was selected to mimic the assumed vent path, the 4-in. HEPA filter vent.

\section{Specific Burn Rate}

The specific burn rate was assigned a value of $1.2 \mathrm{~kg} / \mathrm{m}^{2}$ min on the basis of test results reported by Jordan and Lindner (1983).

Fire Spread Velocity

A radial spread velocity of $1 \mathrm{~cm} / \mathrm{s}$ was assigned on the basis of experimental data reviewed in Appendix C of Grigsby et al (1995). The cited appendix is attached herewith as Attachment 1.

Key results of this example, as documented in the 10 page output file that follows, are described as follows.

\section{Time of Burn}

The oxygen extinguishment level of 13 mole percent is reached at $393 \mathrm{~s}$. Note that the time of extinguishment, and the pressure and temperature at the time of burn-out are printed at each printout after the burn-out time.

\section{Mass of Solvent Burned}

The mass of solvent burned is printed at each output. For this problem, the mass burned is $311.72 \mathrm{lb}$. This number is identified as "MASSBURN."

\section{Peak Pressure}

The peak pressure was reached at 393 seconds. This is indicated on the third page of the output file by the output "PEAK PRESSURE $=17.63675$ AT TIME $=393 . "$ For this case, peak pressure occurs at the time of extinguishment, but this is not necessarily the case for other fire parameters.

\section{Reaction Products Vented}

The parameter $\mathrm{FCO2}$ reaches a minimum value at approximately $1300 \mathrm{sec}$. At this time, a negative pressure has developed due to cooldown. The value of FCO2 is the fraction of $\mathrm{CO}_{2}$ formed by combustion which is retained within the tank. Thus for this problem, (1-0.88) or $12 \%$ of reaction products are released from the tank.

\section{Temperature}

Gas, steel, sludge, solvent, and concrete temperatures are listed for 
each output printing. Sludge and concrete temperatures are printed for each solid node. The distances to the center of each node is printed on page 2 of the output. For example, at $400 \mathrm{~s}$, steel temperature is $131^{\circ} \mathrm{F}$, air temperature is $696^{\circ} \mathrm{F}$, the concrete surface temperature is $194^{\circ} \mathrm{F}$, and the sludge surface temperature is 1 isted as $246^{\circ} \mathrm{F}$.

Other Data

Additional data that are printed are self-explanatory and will not be detailed here. 
WHC-SD-WM-CN-032, REV. 0

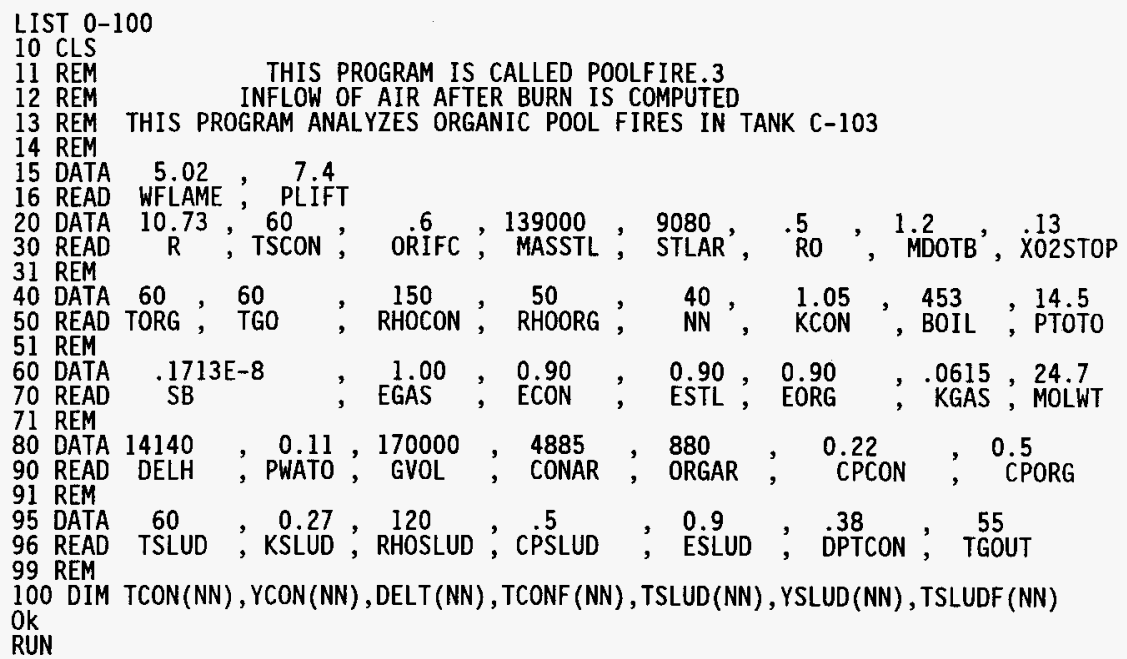

THIS PROGRAM IS CALLED POOLFIRE. 3

THIS PROGRAM ANALYZES TEMPERATURE AND PRESSURE TRANSIENTS IN C-103

THIS VERSION COMPUTES INFLOW OF AIR AFTER FIREOUT

WHAT IS THE EQUIVALENT VENT ORIFICE DIAMETER IN INCHES? 3.75

WHAT IS THE EQUIV. ORIFICE DIA. FOR SALTWELL IN INCHES? O

TOTAL TIME FOR COMPUTATON TO CONTINUE--SEC? 2000

THICKNESS OF ORGANIC POOL--FEET? .2

ASSUMED SPREAD VELOCITY OF FIRE OVER POOL-IN CM/SEC ? 1

THE COMPUTED TIME STEP INTERVAL IS 1.021114 SEC

ENTER A ROUNDED VALUE OF DT THAT IS CLOSE TO THE VALUE ABOVE? I

ENTER THE TIME BETWEEN PRINTOUTS, IN SECONDS? 100

04-08-1996

$13: 49: 23$

KEY INPUT DATA FOR THIS PROBLEM ARE AS FOLLOWS

INITIAL CONCRETE TEMP $=60$ INITIAL ORGANIC TEMP $=60$

GAS VOLUME IN HEAD SPACE $=170000$ TIME STEP $=1$

THICKNESS OF ORGANIC POOL $=.2$ IN FEET

INITIAL GAS TEMPERATURE, $F=60$ INITIAL SLUDGE TEMP, $F=60$

COMBUSTION ENERGY IS 14140 BTU PER LB. OF ORGANIC BURNED

THICKNESS OF CONCRETE MODELLED $=.38 \mathrm{FT}$ 
WHC-SD-WM-CN-032, REV. 0

THICKNESS OF SLUDGE MODELLED $=.1429066 \mathrm{FT}$

POOL BURNING RATE ASSUMED $=1.2 \mathrm{KG} / \mathrm{M} 2 \mathrm{MIN}$

FIRE SPREAD RATE = I CM/SEC---TIME OF SPREAD $=495.8641$ SEC

THE OXYGEN MOLE FRACTION WHERE FIRE STOPS $=.13$

$\begin{array}{cccccccc}\text { FOLLOWING } & \text { ARE DISTANCES FROM CONCRETE SURFACE-FT } & & & \\ 0.00475 & 0.0142 S & 0.02375 & 0.03325 & 0.04275 & 0.05225 & 0.06175 & 0.07125 \\ 0.08075 & 0.09025 & 0.09975 & 0.10925 & 0.11875 & 0.12825 & 0.13775 & 0.14725 \\ 0.15675 & 0.16625 & 0.17575 & 0.18525 & 0.19475 & 0.20425 & 0.21375 & 0.22325 \\ 0.23275 & 0.24225 & 0.25175 & 0.26125 & 0.27075 & 0.28025 & 0.28975 & 0.29925 \\ 0.30875 & 0.31825 & 0.32775 & 0.33725 & 0.34675 & 0.3 S 625 & 0.36575 & 0.37525\end{array}$

FOLLOWING ARE DISTANCES FROM SLUDGE SURFACE--FT
0.00179
0.00536
0.00893
0.01250
0.01608
0.01965
0.02322
0.02679
0.03037
0.03394
0.03751
0.04109
0.04466
0.04823
0.05180
0.05538
0.05895
0.06252
0.06609
0.06967
0.07324
0.07681
0.08038
0.08396
0.11611
0.11968
0.12326
0.12683
0.13040
0.10539
0.10897
0.11254
0.14112

AT TIME $=100$ SEC, FLOW AREA $=7.669921 \mathrm{E}-02 \mathrm{FT}^{\wedge} 2$

BURN RADIUS $=16.73655 \mathrm{FT}$ BURN AREA $=44.36797 \mathrm{FT}^{\wedge} 2 \quad \mathrm{MO20}=92.14253$

GAS TEMP $=97.30551 \mathrm{~F}$ ORGANIC TEMP $=62.04251 \quad \mathrm{X}=2=.2066676$

PRESSURE IN HEADSPACE $=.9826069$ PSIG STEEL TEMP $=60.22489$

MOLES LOST $=1.662689$ VOLUME LEAKED $=738.9508$ CUBIC FT

OUTFLOW RATE $=15.76523$ GAS MOLES IN TANK $=440.4654$ MTOTO $=442.1281$

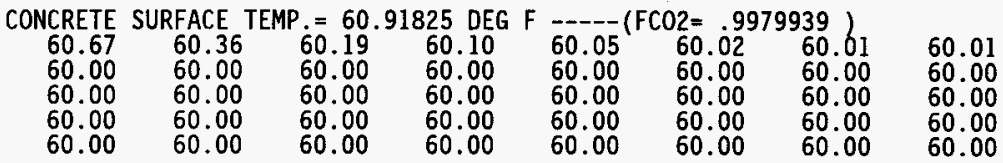

\begin{tabular}{cccccccc} 
SLUDGE SURFACE TEMP & 61.32828 & DEG F & \multicolumn{4}{l}{-MASSBURN $=6.999754$} & \\
60.97 & 60.52 & 60.27 & 60.14 & 60.07 & 60.03 & 60.02 & 60.01 \\
60.00 & 60.00 & 60.00 & 60.00 & 60.00 & 60.00 & 60.00 & 60.00 \\
60.00 & 60.00 & 60.00 & 60.00 & 60.00 & 60.00 & 60.00 & 60.00 \\
60.00 & 60.00 & 60.00 & 60.00 & 60.00 & 60.00 & 60.00 & 60.00 \\
60.00 & 60.00 & 60.00 & 60.00 & 60.00 & 60.00 & 60.00 & 60.00
\end{tabular}

AT TIME $=200$ SEC, FLOW AREA $=7.669921 \mathrm{E}-02 \quad \mathrm{FT}^{\wedge} 2$

BURN RADIUS $=16.73655 \mathrm{FT}$ BURN AREA $=155.3675 \mathrm{FT}^{\wedge} 2 \quad \mathrm{MO20}=92.14253$

GAS TEMP.$=263.5374 \mathrm{~F}$ ORGANIC TEMP $=74.21097 \quad$ X02 $=.1969974$

PRESSURE IN HEADSPACE $=5.369492$ PSIG STEEL TEMP $=63.7963$

MOLES LOST $=6.801544$ VOLUME LEAKED $=3282.662$ CUBIC FT

OUTFLOW RATE $=34.60848$ GAS MOLES IN TANK $=435.3266$ MTOTO $=442.1281$

CONCRETE SURFACE TEMP.$=71.34165$ DEG $F----($ FCO2 $=.9915108)$

$\begin{array}{llllllll}68.98 & 65.64 & 63.50 & 62.15 & 61.30 & 60.78 & 60.46 & 60.27 \\ 60.15 & 60.09 & 60.05 & 60.03 & 60.01 & 60.01 & 60.00 & 60.00 \\ 60.00 & 60.00 & 60.00 & 60.00 & 60.00 & 60.00 & 60.00 & 60.00 \\ 60.00 & 60.00 & 60.00 & 60.00 & 60.00 & 60.00 & 60.00 & 60.00 \\ 60.00 & 60.00 & 60.00 & 60.00 & 60.00 & 60.00 & 60.00 & 60.00\end{array}$

SLUDGE SURFACE TEMP $=76.23911$ DEG $F \quad--M A S S B U R N=45.682$ 


$\begin{array}{llllllll}72.87 & 68.09 & 65.02 & 63.08 & 61.87 & 61.12 & 60.66 & 60.39 \\ 60.22 & 60.13 & 60.07 & 60.04 & 60.02 & 60.01 & 60.01 & 60.00 \\ 60.00 & 60.00 & 60.00 & 60.00 & 60.00 & 60.00 & 60.00 & 60.00 \\ 60.00 & 60.00 & 60.00 & 60.00 & 60.00 & 60.00 & 60.00 & 60.00 \\ 60.00 & 60.00 & 60.00 & 60.00 & 60.00 & 60.00 & 60.00 & 60.00\end{array}$

AT TIME $=300 \mathrm{SEC}$, FLOW AREA $=7.669921 \mathrm{E}-02 \mathrm{FT}^{\wedge} 2$

BURN RADIUS $=16.73655 \mathrm{FT}$ BURN AREA $=333.7332 \mathrm{FT}^{\wedge} 2 \quad \mathrm{MO20}=92.14253$

GAS TEMP $=523.8217 \mathrm{~F}$ ORGANIC TEMP $=108.5236 \quad$ X02 $=.1723219$

PRESSURE IN HEADSPACE $=12.07479$ PSIG STEEL TEMP $=82.08231$

MOLES LOST $=13.99457$ VOLUME LEAKED $=7523.224$ CUBIC FT

OUTFLOW RATE $=49.0795$ GAS MOLES IN TANK $=428.1335$ MTOTO $=442.1281$

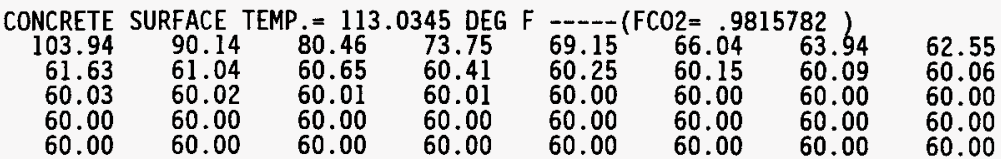

\begin{tabular}{rrrrrrrr}
\multicolumn{2}{l}{ SLUDGE SURFACE TEMP $=134.8799$} & DEG $F$ & \multicolumn{4}{l}{-MASSBURN $=143.5322$} & \\
122.11 & 102.67 & 89.02 & 79.54 & 73.02 & 68.60 & 65.62 & 63.64 \\
62.34 & 61.48 & 60.93 & 60.58 & 60.36 & 60.22 & 60.13 & 60.08 \\
60.05 & 60.03 & 60.02 & 60.01 & 60.01 & 60.00 & 60.00 & 60.00 \\
60.00 & 60.00 & 60.00 & 60.00 & 60.00 & 60.00 & 60.00 & 60.00 \\
60.00 & 60.00 & 60.00 & 60.00 & 60.00 & 60.00 & 60.00 & 60.00
\end{tabular}

AT TIME $=393$ FIRE IS OUT $-\mathrm{PGAGE}=17.63675 \mathrm{TG}=747.569$ DEG F

PEAK PRESSURE $=17.63675$ AT TIME $=393$

THE POOL FIRE IS OUT AT TIME $=393 \mathrm{SEC}$

PEAK PRESSURE $=17.63675$ PSIG AND TEMP $=747.569 \mathrm{DEG} F$

AT TIME $=400$ SEC, FLOW AREA $=7.669921 \mathrm{E}-02 \mathrm{FT}^{\wedge} 2$

BURN RADIUS $=16.73655 \mathrm{FT}$ BURN AREA $=560.0714 \mathrm{FT}^{\wedge} 2 \quad \mathrm{M} 020=92.14253$

GAS TEMP $=685.7245 \mathrm{~F}$ ORGANIC TEMP $=174.2538 \quad \mathrm{X}_{02}=.1297196$

PRESSURE IN HEADSPACE $=15.91964$ PSIG STEEL TEMP $=131.251$

MOLES LOST $=21.32898$ VOLUME LEAKED $=12919.39$ CUBIC FT

OUTFLOW RATE $=55.41987$ GAS MOLES IN TANK $=420.7991$ MTOTO $=442.1281$

CONCRETE SURFACE TEMP $=194.2332$ DEG F $----($ FCO2 $=.9686794)$

$\begin{array}{rrrrrrrr}178.12 & 148.50 & 124.70 & 106.68 & 93.35 & 83.61 & 76.57 & 71.52 \\ 67.94 & 65.43 & 63.68 & 62.47 & 61.65 & 61.09 & 60.71 & 60.46 \\ 60.30 & 60.19 & 60.12 & 60.08 & 60.05 & 60.03 & 60.02 & 60.01 \\ 60.01 & 60.00 & 60.00 & 60.00 & 60.00 & 60.00 & 60.00 & 60.00 \\ 60.00 & 60.00 & 60.00 & 60.00 & 60.00 & 60.00 & 60.00 & 60.00\end{array}$

SLUDGE SURFACE TEMP $=245.785$ DEG $F \quad--M A S S B U R N=311.7244$

$\begin{array}{rrrrrrrr}223.86 & 183.19 & 150.31 & 125.32 & 106.77 & 93.18 & 83.33 & 76.25 \\ 71.22 & 67.68 & 65.22 & 63.51 & 62.34 & 61.55 & 61.02 & 60.66 \\ 60.43 & 60.27 & 60.17 & 60.11 & 60.07 & 60.04 & 60.03 & 60.02 \\ 60.01 & 60.01 & 60.00 & 60.00 & 60.00 & 60.00 & 60.00 & 60.00 \\ 60.00 & 60.00 & 60.00 & 60.00 & 60.00 & 60.00 & 60.00 & 60.00\end{array}$

THE POOL FIRE IS OUT AT TIME $=393 \mathrm{SEC}$

PEAK PRESSURE $=17.63675$ PSIG AND TEMP $=747.569 \mathrm{DEG} F$

AT TIME $=500$ SEC, FLOW AREA $=7.669921 \mathrm{E}-02 \mathrm{FT}^{\wedge} 2$

BURN RADIUS $=16.73655 \mathrm{FT}$ BURN AREA $=560.0714 \mathrm{FT}^{\wedge} 2 \quad \mathrm{M020}=92.14253$ 
GAS TEMP $=337.0449 \mathrm{~F}$ ORGANIC TEMP $=182.5091 \quad X 02=.1297196$

PRESSURE IN HEADSPACE $=6.106041$ PSIG STEEL TEMP $=153.8251$

MOLES LOST $=32.32141$ VOLUME LEAKED $=17419.83$ CUBIC FT

OUTFLOW RATE $=37.65949$ GAS MOLES IN TANK $=409.8067$ MTOTO $=442.1281$

\begin{tabular}{|c|c|c|c|c|c|c|c|}
\hline $\begin{array}{r}\text { CONCRETE } \\
153.98 \\
81.12 \\
61.45 \\
60.06 \\
60.00\end{array}$ & $\begin{array}{r}\text { SURFACE } \\
145.72 \\
75.84 \\
60.99 \\
60.04 \\
60.00\end{array}$ & $\begin{array}{r}\text { TEMP }=157 \\
135.86 \\
71.68 \\
60.67 \\
60.02 \\
60.00\end{array}$ & $\begin{array}{c}1914 \text { DEG } \\
125.24 \\
68.49 \\
60.45 \\
60.01 \\
60.00\end{array}$ & $\begin{array}{r}F---- \\
114.60 \\
66.09 \\
60.30 \\
60.01 \\
60.00\end{array}$ & $\begin{array}{r}104.54 \\
64.32 \\
60.20 \\
60.01 \\
60.00\end{array}$ & $\begin{array}{l}95.48 \\
95 \\
63.03 \\
60.13 \\
60.00 \\
60.00\end{array}$ & $\begin{array}{l}0 \\
0 \\
0\end{array}$ \\
\hline
\end{tabular}

\begin{tabular}{cccccccc} 
SLUDGE SURFACE TEMP $=190.9892$ & DEG F & \multicolumn{7}{c}{-MASSBURN $=311.7244$} & \\
187.06 & 176.52 & 163.61 & 149.48 & 135.16 & 121.52 & 109.15 & 98.40 \\
89.40 & 82.10 & 76.34 & 71.90 & 68.55 & 66.07 & 64.27 & 62.97 \\
62.05 & 61.40 & 60.95 & 60.64 & 60.43 & 60.28 & 60.19 & 60.12 \\
60.08 & 60.05 & 60.03 & 60.02 & 60.01 & 60.01 & 60.01 & 60.00 \\
60.00 & 60.00 & 60.00 & 60.00 & 60.00 & 60.00 & 60.00 & 60.00
\end{tabular}

THE POOL FIRE IS OUT AT TIME $=393$ SEC

PEAK PRESSURE $=17.63675$ PSIG AND TEMP $=747.569 \mathrm{DEG} F$

AT TIME $=600$ SEC, FLOW AREA $=7.669921 \mathrm{E}-02 \mathrm{FT}^{\wedge} 2$

BURN RADIUS $=16.73655 \mathrm{FT}$ BURN AREA $=560.0714 \mathrm{FT}^{\wedge} 2 \quad \mathrm{M020}=92.14253$

GAS TEMP.$=239.104 \mathrm{~F}$ ORGANIC TEMP $=184.2565 \quad X 02=.1297196$

PRESSURE IN HEADSPACE $=3.227316$ PSIG STEEL TEMP $=159.3481$

MOLES LOST $=40.15314$ VOLUME LEAKED $=20700.41$ CUBIC FT

OUTFLOW RATE $=28.72439$ GAS MOLES IN TANK $=401.975$ MTOTO $=442.1281$

\begin{tabular}{rrrrrrrr} 
CONCRETE & SURFACE TEMP. $=137.6908$ DEG & F $-----(F C O 2=$ & \multicolumn{9}{c}{ (F253454) } & \\
136.28 & 132.38 & 127.36 & 121.52 & 115.14 & 108.54 & 101.96 & 95.66 \\
89.79 & 84.48 & 79.80 & 75.77 & 72.37 & 69.57 & 67.31 & 65.50 \\
64.10 & 63.01 & 62.19 & 61.58 & 61.12 & 60.79 & 60.56 & 60.39 \\
60.27 & 60.18 & 60.12 & 60.08 & 60.06 & 60.04 & 60.02 & 60.02 \\
60.01 & 60.01 & 60.00 & 60.00 & 60.00 & 60.00 & 60.00 & 60.00
\end{tabular}

\begin{tabular}{cccccccr} 
SLUDGE SURFACE TEMP $=$ & 163.3205 & DEG F & \multicolumn{4}{c}{- MASSBURN $=311.7244$} & \\
161.73 & 157.04 & 150.74 & 143.21 & 134.87 & 126.12 & 117.35 & 108.87 \\
100.94 & 93.73 & 87.34 & 81.82 & 77.16 & 73.30 & 70.17 & 67.68 \\
65.72 & 64.22 & 63.07 & 62.21 & 61.58 & 61.12 & 60.78 & 60.54 \\
60.37 & 60.26 & 60.17 & 60.12 & 60.08 & 60.05 & 60.03 & 60.02 \\
60.02 & 60.01 & 60.01 & 60.00 & 60.00 & 60.00 & 60.00 & 60.00
\end{tabular}

THE POOL FIRE IS OUT AT TIME $=393$ SEC

PEAK PRESSURE $=17.63675$ PSIG AND TEMP $=747.569$ DEG $F$

AT TIME $=700$ SEC, FLOW AREA $=7.669921 \mathrm{E}-02 \mathrm{FT}^{\wedge} 2$

BURN RADIUS $=16.73655 \mathrm{FT}$ BURN AREA $=560.0714 \mathrm{FT}^{\wedge} 2 \quad \mathrm{MO20}=92.14253$

GAS TEMP $=195.8651 \mathrm{~F}$ ORGANIC TEMP $=184.6889 \quad$ X02 $=.1297196$

PRESSURE IN HEADSPACE $=1.882958$ PSIG STEEL TEMP $=161.3114$

MOLES LOST $=46.13101$ VOLUME LEAKED $=23247.92$ CUBIC FT

OUTFLOW RATE $=22.5959$ GAS MOLES IN TANK $=395.9971$ MTOTO $=442.1281$

\begin{tabular}{|c|c|c|c|c|c|c|c|}
\hline $\begin{array}{r}\text { CONCRETE } \\
125.69 \\
93.31 \\
67.37 \\
60.80 \\
60.05\end{array}$ & $\begin{array}{r}\text { SURFACE } \\
123.32 \\
88.81 \\
65.79 \\
60.58 \\
60.03\end{array}$ & $\begin{array}{r}\text { TEMP }=126 \\
120.19 \\
84.60 \\
64.50 \\
60.42 \\
60.02\end{array}$ & $\begin{array}{c}5351 \text { DEG } \\
116.42 \\
80.75 \\
63.46 \\
60.30 \\
60.02\end{array}$ & $\begin{array}{r}F-.17 \\
112.17 \\
77.28 \\
62.63 \\
60.21 \\
60.01\end{array}$ & $\begin{array}{c}C 02=.91 \\
107.58 \\
74.21 \\
61.98 \\
60.15 \\
60.01\end{array}$ & $\begin{array}{r}5836 \\
102.82 \\
71.55 \\
61.48 \\
60.10 \\
60.00\end{array}$ & $\begin{array}{l}98.02 \\
69.28 \\
61.09 \\
60.07 \\
60.00\end{array}$ \\
\hline
\end{tabular}


WHC-SD-WM-CN-032, REV. 0

$\begin{array}{cccccccr}\text { SLUDGE SURFACE TEMP }=147.6892 & \text { DEG F } & \text {-MASSBURN }=311.7244 & \\ 146.81 & 144.09 & 140.28 & 135.57 & 130.13 & 124.18 & 117.94 & 111.59 \\ 105.33 & 99.31 & 93.65 & 88.43 & 83.73 & 79.56 & 75.93 & 72.82 \\ 70.20 & 68.02 & 66.24 & 64.80 & 63.66 & 62.76 & 62.06 & 61.52 \\ 61.12 & 60.81 & 60.58 & 60.42 & 60.30 & 60.21 & 60.15 & 60.10 \\ 60.07 & 60.05 & 60.03 & 60.02 & 60.01 & 60.01 & 60.01 & 60.00\end{array}$

THE POOL FIRE IS OUT AT TIME $=393$ SEC

PEAK PRESSURE $=17.63675$ PSIG AND TEMP $=747.569 \mathrm{DEG} F$

AT TIME $=800$ SEC, FLOW AREA $=7.669921 \mathrm{E}-02 \mathrm{FT}^{\wedge} 2$

BURN RADIUS $=16.73655 \mathrm{FT} \quad$ BURN AREA $=560.0714 \mathrm{FT}^{\wedge} 2 \quad \mathrm{MO20}=92.14253$

GAS TEMP.$=173.1548 \mathrm{~F}$ ORGANIC TEMP $.=184.6759 \quad \times 02=.1297196$

PRESSURE IN HEADSPACE $=1.129314$ PSIG STEEL TEMP $=161.9836$

MOLES LOST $=50.78858$ VOLUME LEAKED $=25259.45$ CUBIC FT

OUTFLOW RATE $=17.84754$ GAS MOLES IN TANK $=391.3395$ MTOTO $=442.1281$

CONCRETE SURFACE TEMP $=119.2743$ DEG F $----($ FCO2 $=.9008619)$

$\begin{array}{rrrrrrrr}118.67 & 117.00 & 114.78 & 112.08 & 108.99 & 105.59 & 101.97 & 98.23 \\ 94.45 & 90.72 & 87.12 & 83.68 & 80.48 & 77.52 & 74.84 & 72.45 \\ 70.34 & 68.50 & 66.93 & 65.59 & 64.47 & 63.54 & 62.78 & 62.16 \\ 61.67 & 61.27 & 60.97 & 60.73 & 60.54 & 60.40 & 60.29 & 60.22 \\ 60.16 & 60.11 & 60.08 & 60.06 & 60.04 & 60.03 & 60.02 & 60.01\end{array}$

SLUDGE SURFACE TEMP $=137.5849$ DEG $F \quad--M A S S B U R N=311.7244$

$\begin{array}{rrrrrrrr}136.99 & 135.14 & 132.52 & 129.22 & 125.34 & 121.01 & 116.34 & 111.47 \\ 106.51 & 101.58 & 96.79 & 92.20 & 87.90 & 83.92 & 80.31 & 77.06 \\ 74.20 & 71.70 & 69.54 & 67.71 & 66.17 & 64.90 & 63.85 & 63.00 \\ 62.32 & 61.77 & 61.35 & 61.01 & 60.76 & 60.56 & 60.41 & 60.30 \\ 60.22 & 60.16 & 60.11 & 60.08 & 60.05 & 60.04 & 60.02 & 60.01\end{array}$

THE POOL FIRE IS OUT AT TIME $=393 \mathrm{SEC}$

PEAK PRESSURE $=17.63675$ PSIG AND TEMP $=747.569$ DEG $F$

AT TIME $=900$ SEC, FLOW AREA $=7.669921 \mathrm{E}-02 \mathrm{FT}^{\wedge} 2$

BURN RADIUS $=16.73655 \mathrm{FT}$ BURN AREA $=560.0714 \mathrm{FT}^{\wedge} 2 \quad \mathrm{MO20}=92.14253$

GAS TEMP.$=159.9213 \mathrm{~F}$ ORGANIC TEMP $=184.4522 \quad X 02=.1297196$

PRESSURE IN HEADSPACE $=.6610289$ PSIG STEEL TEMP $=162.0915$

MOLES LOST $=54.405$ VOLUME LEAKED $=26837.84$ CUBIC FT

OUTFLOW RATE $=13.84714$ GAS MOLES IN TANK $=387.7231 \quad$ MTOTO $=442.1281$

\begin{tabular}{|c|c|c|c|c|c|c|c|}
\hline $\begin{array}{r}\text { CONCRETE } \\
113.68 \\
94.54 \\
72.73 \\
62.75 \\
60.36\end{array}$ & $\begin{array}{r}\text { SURFACE T } \\
112.37 \\
91.42 \\
70.82 \\
62.19 \\
60.27\end{array}$ & $\begin{array}{c}\text { TEMP. }=114 \\
110.66 \\
88.34 \\
69.11 \\
61.73 \\
60.20\end{array}$ & $\begin{array}{c}1581 \text { DEG } \\
108.58 \\
85.34 \\
67.61 \\
61.36 \\
60.15\end{array}$ & $\begin{array}{r}F----(106.18 \\
82.46 \\
66.31 \\
61.06 \\
60.10\end{array}$ & $\begin{array}{r}C 02=.85 \\
103.51 \\
79.74 \\
65.19 \\
60.82 \\
60.07\end{array}$ & $\begin{array}{r}5368 \\
100.64 \\
77.20 \\
64.23 \\
60.63 \\
60.04\end{array}$ & $\begin{array}{l}97.63 \\
74.86 \\
63.42 \\
60.48 \\
60.02\end{array}$ \\
\hline
\end{tabular}

SLUDGE SURFACE TEMP $=130.4953$ DEG $F \quad--$ MASSBURN $=311.7244$

$\begin{array}{rrrrrrrr}130.04 & 128.63 & 126.66 & 124.16 & 121.20 & 117.86 & 114.21 & 110.33 \\ 106.32 & 102.25 & 98.19 & 94.23 & 90.40 & 86.77 & 83.38 & 80.23 \\ 77.36 & 74.78 & 72.47 & 70.44 & 68.66 & 67.13 & 65.82 & 64.72 \\ 63.79 & 63.02 & 62.39 & 61.88 & 61.46 & 61.13 & 60.87 & 60.66 \\ 60.50 & 60.37 & 60.28 & 60.20 & 60.14 & 60.10 & 60.06 & 60.03\end{array}$

THE POOL FIRE IS OUT AT TIME $=393$ SEC

PEAK PRESSURE $=17.63675$ PSIG AND TEMP $=747.569$ DEG $F$

AT TIME $=1000$ SEC, FLOW AREA $=7.669921 \mathrm{E}-02 \mathrm{FT}^{\wedge} 2$

BURN RADIUS $=16.73655 \mathrm{FT}$ BURN AREA $=560.0714 \mathrm{~F}^{\wedge} 2 \quad \mathrm{M} 020=92.14253$ 
GAS TEMP $=151.7173 \mathrm{~F}$ ORGANIC TEMP $=184.098 \quad X 02=.1297196$

PRESSURE IN HEADSPACE $=.3549986$ PSIG STEEL TEMP $=16 \mathrm{i} .9204$

MOLES LOST $=57.13303$ VOLUME LEAKED $=28038.24$ CUBIC FT

OUTFLOW RATE $=10.2517$ GAS MOLES IN TANK $=384.9951 \quad$ MTOTO $=442.1281$

$\begin{array}{rrrrrrrr}\text { CONCRETE } & \text { SURFACE TEMP }=110.359 \text { DEG } & \text { F } & -1-5 & \text { (FC02 } & .8862566) & \\ 109.95 & 108.86 & 107.45 & 105.75 & 103.79 & 101.62 & 99.25 & 96.75 \\ 94.16 & 91.51 & 88.86 & 86.23 & 83.66 & 81.19 & 78.84 & 76.63 \\ 74.57 & 72.67 & 70.94 & 69.38 & 67.98 & 66.75 & 65.66 & 64.72 \\ 63.90 & 63.21 & 62.62 & 62.12 & 61.71 & 61.36 & 61.08 & 60.85 \\ 60.66 & 60.51 & 60.39 & 60.30 & 60.22 & 60.15 & 60.09 & 60.05\end{array}$

SLUDGE SURFACE TEMP $=125.2441$ DEG $F \quad--$ MASSBURN $=311.7244$

$\begin{array}{rrrrrrrr}124.85 & 123.70 & 122.11 & 120.10 & 117.73 & 115.03 & 112.06 & 108.89 \\ 105.55 & 102.13 & 98.67 & 95.23 & 91.85 & 88.58 & 85.46 & 82.51 \\ 79.76 & 77.21 & 74.89 & 72.78 & 70.90 & 69.22 & 67.75 & 66.46 \\ 65.36 & 64.41 & 63.60 & 62.92 & 62.35 & 61.88 & 61.49 & 61.18 \\ 60.92 & 60.71 & 60.54 & 60.41 & 60.30 & 60.21 & 60.13 & 60.06\end{array}$

THE POOL FIRE IS OUT AT TIME $=393$ SEC

PEAK PRESSURE $=17.63675$ PSIG AND TEMP $=747.569$ DEG $F$

AT TIME $=1100$ SEC, FLOW AREA $=7.669921 \mathrm{E}-02 \mathrm{FT}^{\wedge} 2$

BURN RADIUS $=16.73655 \mathrm{FT}$ BURN AREA $=560.0714 \mathrm{FT}^{\wedge} 2 \quad \mathrm{MO} 20=92.14253$

GAS TEMP $=146.6294 \mathrm{~F}$ ORGANIC TEMP $=183.6655 \quad X 02=.1297196$

PRESSURE IN HEADSPACE $=.1575337$ PSIG STEEL TEMP $=161.5732$

MOLES LOST $=59.0625$ VOLUME LEAKED $=28892.39$ CUBIC FT

OUTFLOW RATE $=6.88228$ GAS MOLES IN TANK $=383.0656$ MTOTO $=442.1281$

$\begin{array}{rrrrrrrr}\text { CONCRETE } & \text { SURFACE TEMP }=107.447 \text { DEG F } & -5--(F C 02=.8818149) & \\ 107.07 & 106.11 & 104.89 & 103.45 & 101.79 & 99.95 & 97.94 & 9 S .81 \\ 93.59 & 91.30 & 88.98 & 86.66 & 84.37 & 82.14 & 79.98 & 77.91 \\ 75.96 & 74.13 & 72.43 & 70.86 & 69.43 & 68.14 & 66.98 & 65.95 \\ 65.04 & 64.24 & 63.55 & 62.95 & 62.43 & 62.00 & 61.63 & 61.31 \\ 61.05 & 60.84 & 60.66 & 60.50 & 60.38 & 60.27 & 60.17 & 60.08\end{array}$

\begin{tabular}{cccccccr}
\multicolumn{2}{c}{ SLUDGE SURFACE TEMP $=121.2254$} & DEG F & \multicolumn{2}{c}{-MASSBURN= 311.7244} & \\
120.87 & 119.86 & 118.50 & 116.82 & 114.83 & 112.57 & 110.09 & 107.40 \\
104.58 & 101.64 & 98.65 & 95.64 & 92.64 & 89.71 & 86.86 & 84.13 \\
81.54 & 79.10 & 76.82 & 74.73 & 72.81 & 71.07 & 69.51 & 68.11 \\
66.88 & 65.80 & 64.85 & 64.04 & 63.34 & 62.74 & 62.24 & 61.81 \\
61.45 & 61.15 & 60.90 & 60.70 & 60.52 & 60.37 & 60.24 & 60.11
\end{tabular}

THE POOL FIRE IS OUT AT TIME $=393$ SEC

PEAK PRESSURE $=17.63675$ PSIG AND TEMP $=747.569 \mathrm{DEG} F$

AT TIME $=1200$ SEC, FLOW AREA $=7.669921 \mathrm{E}-02 \quad \mathrm{FT}^{\wedge} 2$

BURN RADIUS $=16.73655$ FT BURN AREA $=560.0714 \mathrm{FT}^{\wedge} 2 \quad \mathrm{M} 020=92.14253$

GAS TEMP $=143.4531 \mathrm{~F}$ ORGANIC TEMP $=183.1869 \quad$ XO2 $=.1297196$

PRESSURE IN HEADSPACE $=3.667069 E-02$ PSIG STEEL TEMP $=161.1198$

MOLES LOST $=60.22019$ VOLUME LEAKED $=29407.04$ CUBIC FT

OUTFLOW RATE $=3.353166$ GAS MOLES IN TANK $=381.9079$ MTOTO $=442.1281$

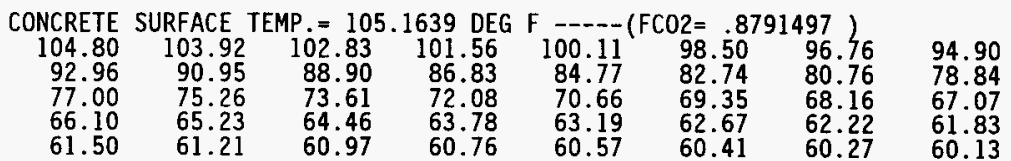


WHC-SD-WM-CN-032, REV. 0

\begin{tabular}{rrrrrrrr}
\multicolumn{2}{c}{ SLUDGE SURFACE TEMP $=$} & 118.0769 & DEG F & --MASSBURN $=311.7244$ & \\
117.73 & 116.80 & 115.60 & 114.13 & 112.41 & 110.46 & 108.31 & 106.00 \\
103.55 & 100.99 & 98.36 & 95.70 & 93.03 & 90.38 & 87.79 & 85.27 \\
82.84 & 80.53 & 78.35 & 76.31 & 74.41 & 72.66 & 71.06 & 69.60 \\
68.29 & 67.12 & 66.08 & 65.16 & 64.35 & 63.65 & 63.04 & 62.51 \\
62.06 & 61.67 & 61.33 & 61.04 & 60.79 & 60.57 & 60.37 & 60.18
\end{tabular}

THE POOL FIRE IS OUT AT TIME $=393$ SEC

PEAK PRESSURE $=17.63675$ PSIG AND TEMP $=747.569$ DEG $F$

AT TIME $=1300 \mathrm{SEC}$, FLOW AREA $=7.669921 \mathrm{E}-02 \mathrm{FT} \wedge 2$

BURN RADIUS $=16.73655 \mathrm{FT}$ BURN AREA $=560.0714 \mathrm{FT}^{\wedge} 2 \quad \mathrm{MO20}=92.14253$

GAS TEMP. $=141.5237 \mathrm{~F}$ ORGANIC TEMP $=182.6831 \quad \mathrm{X} 02=.1297196$

PRESSURE IN HEADSPACE $=-1.924038 E-02$ PSIG STEEL TEMP $=160.6084$

MOLES LOST $=60.46799$ VOLUME LEAKED $=29517.38$ CUBIC FT

OUTFLOW RATE $=0$ GAS MOLES IN TANK $=381.6601$ MTOTO $=442.1281$

\begin{tabular}{|c|c|c|c|c|c|c|c|}
\hline $\begin{array}{r}\text { CONCRETE } \\
102.99 \\
92.33 \\
77.79 \\
67.07 \\
61.97\end{array}$ & $\begin{array}{l}\text { SURFACE } \\
102.15 \\
90.54 \\
76.14 \\
66.15 \\
61.62\end{array}$ & $\begin{array}{r}\text { TEMP }=103 \\
101.15 \\
88.70 \\
74.56 \\
65.33 \\
61.31\end{array}$ & $\begin{array}{c}3447 \text { DEG } \\
100.00 \\
86.84 \\
73.08 \\
64.59 \\
61.04\end{array}$ & $\begin{array}{l}F \quad---(10 \\
98.70 \\
84.97 \\
71.68 \\
63.93 \\
60.80\end{array}$ & $\begin{array}{r}02=.8 \\
97.26 \\
83.12 \\
70.38 \\
63.34 \\
60.58\end{array}$ & $\begin{array}{r}792 \\
95.71 \\
81.29 \\
69.18 \\
62.83 \\
60.38\end{array}$ & $\begin{array}{l}94.06 \\
79.51 \\
68.08 \\
62.37 \\
60.18\end{array}$ \\
\hline
\end{tabular}

SLUDGE SURFACE TEMP $=115.5685$ DEG $F \quad-$ MASSBURN $=311.7244$

$\begin{array}{rrrrrrrr}115.22 & 114.34 & 113.23 & 111.90 & 110.37 & 108.65 & 106.76 & 104.71 \\ 102.55 & 100.28 & 97.95 & 95.56 & 93.16 & 90.76 & 88.39 & 86.06 \\ 83.80 & 81.63 & 79.55 & 77.59 & 75.73 & 74.00 & 72.40 & 70.92 \\ 69.57 & 68.34 & 67.23 & 66.24 & 65.35 & 64.55 & 63.85 & 63.24 \\ 62.69 & 62.22 & 61.80 & 61.42 & 61.09 & 60.79 & 60.51 & 60.25\end{array}$

THE POOL FIRE IS OUT AT TIME $=393$ SEC

PEAK PRESSURE $=17.63675$ PSIG AND TEMP $=747.569$ DEG $F$

AT TIME $=1400$ SEC, FLOW AREA $=7.669921 \mathrm{E}-02 \mathrm{FT}^{\wedge} 2$

BURN RADIUS $=16.73655 \mathrm{FT}$ BURN AREA $=560.0714 \mathrm{FT}^{\wedge} 2 \quad M 020=92.14253$

GAS TEMP.$=140.049 \mathrm{~F}$ ORGANIC . TEMP $=182.1657 \quad X 02=.1297196$

PRESSURE IN HEADSPACE $=-.0547638$ PSIG STEEL TEMP $=160.065$

MOLES LOST $=60.46799$ VOLUME LEAKED $=29517.38$ CUBIC FT

OUTFLOW RATE $=0$ GAS MOLES IN TANK $=381.6601 \quad$ MTOTO $=442.1281$

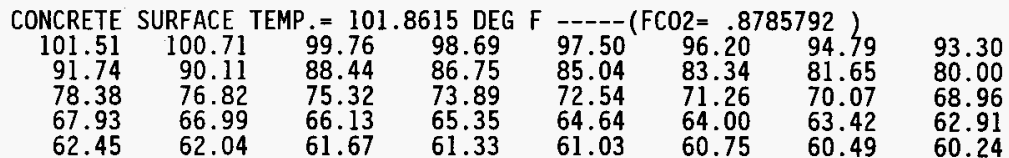

\begin{tabular}{rccccccr}
\multicolumn{2}{c}{ SLUDGE SURFACE TEMP $=113.523$} & DEG F & \multicolumn{1}{c}{-MASSBURN=311.7244 } & \\
113.17 & 112.32 & 111.28 & 110.05 & 108.66 & 107.10 & 105.39 & 103.56 \\
101.62 & 99.58 & 97.47 & 95.32 & 93.13 & 90.94 & 88.76 & 86.61 \\
84.51 & 82.46 & 80.50 & 78.61 & 76.82 & 75.13 & 73.55 & 72.07 \\
70.70 & 69.44 & 68.29 & 67.24 & 66.28 & 65.42 & 64.65 & 63.95 \\
63.33 & 62.77 & 62.27 & 61.82 & 61.41 & 61.03 & 60.67 & 60.33
\end{tabular}

THE POOL FIRE IS OUT AT TIME $=393$ SEC

PEAK PRESSURE $=17.63675$ PSIG AND TEMP $=747.569$ DEG $F$

AT TIME $=1500$ SEC, FLOW AREA $=7.669921 \mathrm{E}-02 \mathrm{FT}^{\wedge} 2$

BURN RADIUS $=16.73655 \mathrm{FT}^{\mathrm{B}}$ BURN AREA $=560.0714 \mathrm{FT}^{\wedge} 2 \quad \mathrm{MO20}=92.14253$ 
GAS TEMP $=138.7902 \mathrm{~F}$ ORGANIC TEMP $=181.6388 \quad \mathrm{XO2}=.1297196$

PRESSURE IN HEADSPACE $=-8.508778 E-02$ PSIG STEEL TEMP $=159.4989$

MOLES LOST $=60.46799$ VOLUME LEAKED $=29517.38$ CUBIC FT

OUTFLOW RATE $=0$ GAS MOLES IN TANK $=381.6601$ MTOTO $=442.1281$

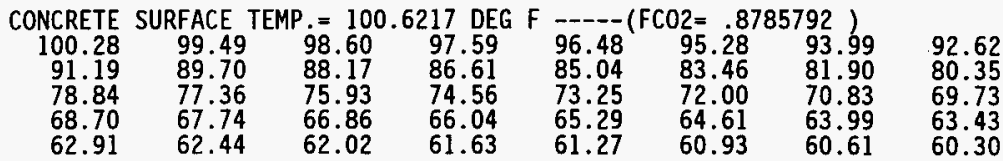

\begin{tabular}{cccccccr}
\multicolumn{6}{c}{ SLUDGE SURFACE TEMP $=111.812$} & DEG F & \multicolumn{7}{c}{-MASSBURN $=311.7244$} & \\
111.46 & 110.63 & 109.63 & 108.49 & 107.19 & 105.76 & 104.20 & 102.53 \\
100.76 & 98.91 & 96.99 & 95.02 & 93.02 & 91.00 & 88.99 & 86.99 \\
85.02 & 83.10 & 81.24 & 79.44 & 77.72 & 76.07 & 74.52 & 73.06 \\
71.69 & 70.42 & 69.24 & 68.15 & 67.15 & 66.24 & 65.40 & 64.64 \\
63.95 & 63.32 & 62.74 & 62.21 & 61.72 & 61.26 & 60.83 & 60.41
\end{tabular}

NEGATIVE PRESSURE AT 1555 SEC

THE POOL FIRE IS OUT AT TIME $=393$ SEC

PEAK PRESSURE $=17.63675$ PSIG AND TEMP $=747.569 \mathrm{DEG} F$

AT TIME $=1600 \mathrm{SEC}$, FLOW AREA $=7.669921 \mathrm{E}-02 \mathrm{FT}^{\wedge} 2$

BURN RADIUS $=16.73655 \mathrm{FT}$ BURN AREA $=560.0714 \mathrm{FT}^{\wedge} 2 \quad \mathrm{M020}=92.14253$

GAS TEMP.$=137.5631 \mathrm{~F}$ ORGANIC TEMP $=181.1036 \quad X 02=.1298397$

PRESSURE IN HEADSPACE $=-9.250832 E-02$ PSIG STEEL TEMP $=158.9159$

MOLES LOST $=59.88062$ VOLUME LEAKED $=29293.71$ CUBIC FT

OUTFLOW RATE $=-4.873826$ GAS MOLES IN TANK $=382.2475$ MTOTO $=442.1281$

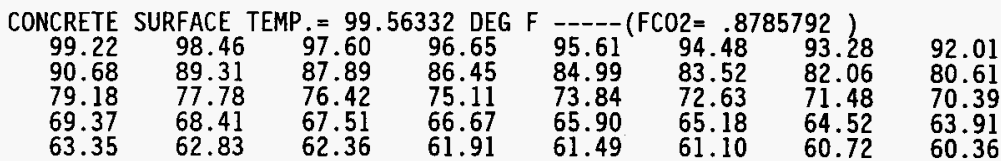

\begin{tabular}{cccccccr} 
SLUDGE SURFACE TEMP & 110.3512 & DEG $F$ & \multicolumn{5}{c}{-MASSBURN $=311.7244$} \\
110.00 & 109.18 & 108.23 & 107.15 & 105.93 & 104.60 & 103.16 & 101.62 \\
99.99 & 98.28 & 96.51 & 94.70 & 92.85 & 90.98 & 89.11 & 87.24 \\
85.40 & 83.59 & 81.82 & 80.10 & 78.45 & 76.86 & 75.35 & 73.91 \\
72.55 & 71.28 & 70.09 & 68.97 & 67.94 & 66.98 & 66.10 & 65.28 \\
64.53 & 63.83 & 63.19 & 62.59 & 62.03 & 61.49 & 60.98 & 60.49
\end{tabular}

THE POOL FIRE IS OUT AT TIME $=393$ SEC

PEAK PRESSURE $=17.63675$ PSIG AND TEMP $=747.569 \mathrm{DEG} F$

AT TIME $=1700$ SEC, FLOW AREA $=7.669921 \mathrm{E}-02 \mathrm{FT}^{\wedge} 2$

BURN RADIUS $=16.73655$ FT BURN AREA $=560.0714 \mathrm{FT}^{\wedge} 2 \quad \mathrm{M020}=92.14253$

GAS TEMP.$=136.415 \mathrm{~F}$ ORGANIC TEMP $.=180.5615 \quad X 02=.1300875$

PRESSURE IN HEADSPACE $=-7.448673 \mathrm{E}-02$ PSIG STEEL TEMP $=158.3152$

MOLES LOST $=58.66519$ VOLUME LEAKED $=28830.85$ CUBIC FT

OUTFLOW RATE $=-4.375761$ GAS MOLES IN TANK $=383.4629$ MTOTO $=442.1281$

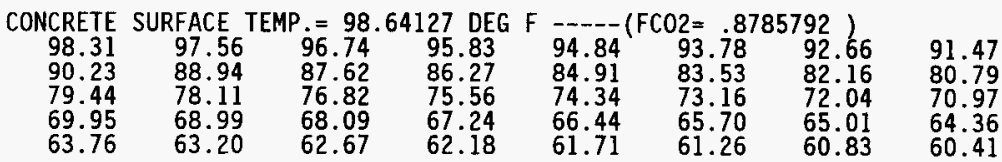




\begin{tabular}{cccccccr} 
SLUDGE SURFACE TEMP $=109.0773$ & DEG F & \multicolumn{5}{c}{-MASSBURN $=311.7244$} & \\
108.73 & 107.93 & 107.01 & 105.98 & 104.83 & 103.58 & 102.24 & 100.80 \\
99.28 & 97.70 & 96.06 & 94.37 & 92.65 & 90.91 & 89.16 & 87.41 \\
85.67 & 83.96 & 82.28 & 80.64 & 79.05 & 77.52 & 76.04 & 74.64 \\
73.30 & 72.03 & 70.83 & 69.70 & 68.65 & 67.66 & 66.73 & 65.87 \\
65.07 & 64.31 & 63.61 & 62.94 & 62.31 & 61.71 & 61.13 & 60.56
\end{tabular}

THE POOL FIRE IS OUT AT TIME $=393$ SEC

PEAK PRESSURE $=17.63675$ PSIG AND TEMP $=747.569$ DEG $F$

AT TIME $=1800$ SEC, FLOW AREA $=7.669921 \mathrm{E}-02 \quad \mathrm{FT}^{\wedge} 2$

BURN RADIUS $=16.73655 \mathrm{FT}$ BURN AREA $=560.0714 \mathrm{FT}^{\wedge} 2 \quad M 020=92.14253$

GAS TEMP $=135.4646 \mathrm{~F}$ ORGANIC TEMP $=180.0122 \quad$ XO2 $=.1303057$

PRESSURE IN HEADSPACE $=-5.702687 E-02$ PSIG STEEL TEMP $=157.7031$

MOLES LOST $=57.58795$ VOLUME LEAKED $=28420.61$ CUBIC FT

OUTFLOW RATE $=-3.830424$ GAS MOLES IN TANK $=384.5401$ MTOTO $=442.1281$

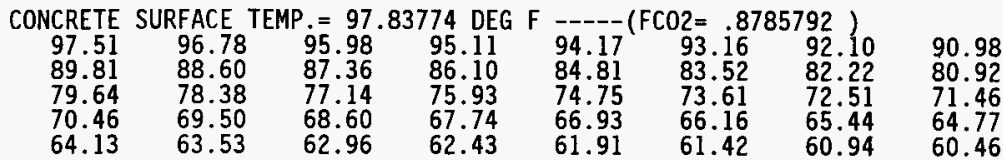

\begin{tabular}{cccccccr} 
SLUDGE SURFACE TEMP & $=107.9667$ & DEG F & \multicolumn{3}{c}{-MASSBURN= } & 311.7244 & \\
107.62 & 106.83 & 105.94 & 104.95 & 103.86 & 102.68 & 101.41 & 100.06 \\
98.64 & 97.16 & 95.62 & 94.04 & 92.43 & 90.80 & 89.15 & 87.50 \\
85.86 & 84.24 & 82.64 & 81.07 & 79.54 & 78.06 & 76.63 & 75.25 \\
73.94 & 72.68 & 71.48 & 70.35 & 69.27 & 68.26 & 67.30 & 66.40 \\
65.55 & 64.75 & 63.99 & 63.27 & 62.57 & 61.91 & 61.26 & 60.63
\end{tabular}

THE POOL FIRE IS OUT AT TIME $=393$ SEC

PEAK PRESSURE $=17.63675$ PSIG AND TEMP $=747.569$ DEG $F$

AT TIME $=1900$ SEC, FLOW AREA $=7.669921 \mathrm{E}-02 \mathrm{FT}^{\wedge} 2$

BURN RADIUS $=16.73655 \mathrm{FT}$ BURN AREA $=560.0714 \mathrm{FT}^{\wedge} 2 \quad \mathrm{MO20}=92.14253$

GAS TEMP $=134.6454 \mathrm{~F}$ ORGANIC TEMP $=179.4629 \quad X 02=.1304938$

PRESSURE IN HEADSPACE $=-4.191303 E-02$ PSIG STEEL TEMP $=157.0837$

MOLES LOST $=56.65488$ VOLUME LEAKED $=28065.27$ CUBIC FT

OUTFLOW RATE $=-3.284726$ GAS MOLES IN TANK $=385.4732$ MTOTO $=442.1281$

$\begin{array}{rrrrrrrr}\text { CONCRETE } & \text { SURFACE TEMP }=97.13327 \text { DEG } & \text { F } & -----(\text { FCO2= } & .8785792) & \\ 96.80 & 96.09 & 95.31 & 94.47 & 93.57 & 92.61 & 91.60 & 90.54 \\ 89.43 & 88.29 & 87.12 & 85.92 & 84.70 & 83.48 & 82.25 & 81.02 \\ 79.79 & 78.59 & 77.40 & 76.23 & 75.09 & 73.99 & 72.92 & 71.89 \\ 70.90 & 69.95 & 69.04 & 68.18 & 67.36 & 66.58 & 65.84 & 65.14 \\ 64.47 & 63.83 & 63.23 & 62.65 & 62.09 & 61.55 & 61.03 & 60.51\end{array}$

SLUDGE SURFACE TEMP $=106.992$ DEG $F \quad-$-MASSBURN $=311.7244$

$\begin{array}{rrrrrrrr}106.64 & 105.87 & 105.00 & 104.05 & 103.00 & 101.88 & 100.67 & 99.40 \\ 98.06 & 96.66 & 95.21 & 93.73 & 92.21 & 90.67 & 89.11 & 87.55 \\ 86.00 & 84.45 & 82.92 & 81.42 & 79.95 & 78.51 & 77.12 & 75.78 \\ 74.48 & 73.24 & 72.04 & 70.91 & 69.82 & 68.79 & 67.81 & 66.87 \\ 65.99 & 65.14 & 64.33 & 63.56 & 62.81 & 62.09 & 61.38 & 60.69\end{array}$

THE POOL FIRE IS OUT AT TIME $=393$ SEC

PEAK PRESSURE $=17.63675$ PSIG AND TEMP $=747.569$ DEG $\mathrm{F}$

AT TIME $=2000$ SEC, FLOW AREA $=7.669921 \mathrm{E}-02 \mathrm{FT}^{\wedge} 2$ 
BURN RADIUS $=16.73655 \mathrm{FT}$ BURN AREA $=560.0714 \mathrm{FT}^{\wedge} 2 \quad \mathrm{MO20}=92.14253$

GAS TEMP $=133.9164 \mathrm{~F}$ ORGANIC TEMP $=178.9113$ X02 $=.1306531$

PRESSURE IN HEADSPACE $=-2.991295 E-02$ PSIG STEEL TEMP $=156.4612$

MOLES LOST $=55.86109$ VOLUME LEAKED $=27762.95$ CUBIC FT

OUTFLOW RATE $=-2.775138$ GAS MOLES IN TANK $=386.267$ MTOTO $=442.1281$

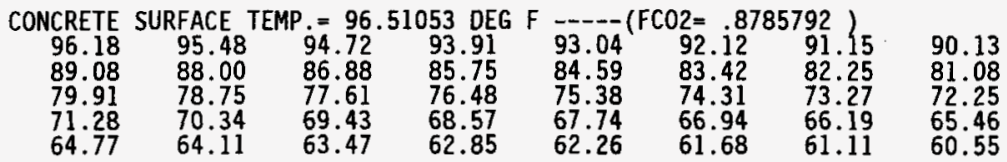

SLUDGE SURFACE TEMP $=106.1296$ DEG F --MASSBURN $=311.7244$

$\begin{array}{rrrrrrrr}105.78 & 105.01 & 104.17 & 103.24 & 102.23 & 101.16 & 100.01 & 98.79 \\ 97.52 & 96.20 & 94.83 & 93.42 & 91.98 & 90.52 & 89.05 & 87.56 \\ 86.08 & 84.60 & 83.14 & 81.70 & 80.28 & 78.89 & 77.54 & 76.22 \\ 74.95 & 73.72 & 72.53 & 71.39 & 70.30 & 69.25 & 68.25 & 67.29 \\ 66.37 & 65.49 & 64.64 & 63.82 & 63.02 & 62.25 & 61.49 & 60.74\end{array}$

ok 


\subsection{CONFIRMATION OF POOLFIRE.3}

An independent analysis of solvent fires was carried out at FAI by $M$. Epstein. The purpose of the exercise was to confirm the numerical validity of pressures computed by Poolfire. The fire assumptions made by Epstein were consistent with those used in Grigsby et al (1995) so that results could be compared on a numerical basis.

The memo that conveyed Epstein's analysis is included herewith as Attachment 3 . The findings have been interpreted as supporting the validity of Poolfire 3. Differences between Epstein's model and Poolfire are thought to be explainable in terms of different assumptions used in the two models.

In addition to Epstein's independent analysis, the method embodied in Poolfire. 3 was peer-reviewed by R. Crowe, of Westinghouse Hanford. Crowe's checklist for Technical Peer Review is included herewith as Attachment 4.

\subsection{LITERATURE CITED}

Carslaw, H. S. and J. C. Jaeger, 1959, Conduction of Heat in Solids, Second Edition, 0xford at the Claredon Press, London.

Daniels, F. and R. A. Alberty, 1995, Physical Chemistry," New York, New York.

Fox, G. L., T. E. Beaver, D. B. Bechtold, D. L. Herting, A. K. Postma, P. K. Shen, and D, D. Stepnewski, 1991, Tank 241-SY-101 Crust Burn Analysis, WHC-SD-WM-SAR-046, Rev. 0, Westinghouse Hanford Company, Richland, Washington.

Grigsby, J. M., J. E. Meacham, D. A. Turner, J. C. Van Keuren, M. G. Plys, M. Epstein, H. K. Fauske, J. P. Burelbach, and A. K. Postma, 1995, Risk from Organic Solvent Fires in $\mathrm{C}-103$ following Interim Stabilization, WHC-SD-WM-SARR-001, Supplement 1, Rev. 0-A, Westinghouse Hanford Company, Richland, Washington, March 1995.

Hörman, E., 1983, "Analysis of Fire and Explosion Accidents in a Fuel Reprocessing Plant," pp 132-151, in Proceeding of the CSNI Specialist Meeting on Interaction of Fire and Explosion with Ventilation Systems in Nuclear Facilities, LA-9911-C-Vol. 1, Los Alamos, New Mexico, April 25-28, 1983.

Hougen, 0. A., K. M., Watson, and R. A. Ragatz, 1954, "Chemical Process Principles, Part I, Material and Energy Balances," John Wiley \& Sons, Inc., New York, New York.

Hougen, 0. A., K. M., Watson, and R. A. Ragatz, 1959, "Chemical Process Principles, Part II, Thermodynamics," John Wiley \& Sons, Inc., New York, New York.

Jordan, S. and W. Lindner, 1983, "The Behavior of Burning Kerosene, Aerosol 
Formation and Consequences" in Proceedings of the CSNI Specialist Meeting on Interaction of Fire and Explosion with Ventilation Systems in Nuclear Facilities, LA-9911-C, Vol. I, Los Alamos, New Mexico, April 25-28, 1983.

Malet, J. C., et al, 1983, "Solvent Pool Fire Testing" in Proceedings of the CSNI Specialist Meeting on Interaction of Fire and Explosion with Ventilation Systems in Nuclear Facilities, LA-9911-C, Vol. II, Los Alamos, New Mexico, April 25-28, 1983.

McAdams, W. H., 1954, Heat Transmission, Mc-Graw-Hi11 Book Company, New York, New York.

Perry, J. H., Ed., 1950, "Chemical Engineers' Handbook," McGraw-Hill Book Company, Third Edition, New York, New York

Pool, K. H. and R. M. Bean, 1994, PNL-9403, Waste Tank Safety Project: Analysis of Liquid Samples from Hanford Waste Tank 241-C-103, Pacific Northwest Laboratory, Richland, Washington. 
WHC-SD-WM-CN-032, REV. 0

\section{ATTACHMENT A-1}

\section{APPENDIX C FROM WHC-SD-WM-SARR-001,} REV. O-A, SUPPLEMENT 1

This attachment provides a technical basis for many of the inputs used to analyze postulated pool fires. It also describes the phenomenology of pool fires in closed compartments. 
WHC-SD-WM-CN-032, REV. 0

This page intentionally left blank. 
WHC-SD-WM-CN-032, REV. 0

\section{APPENDIX C}

POTENTIAL CONSEqUENCES OF POSTULATED SOLVENT FIRES IN TANK C-103 
WHC-SD-WM-CN-032, REV. 0

nef. WHC-SD-WM-SARR-001 REV 0-A
SUPPLEMENT 1

This page intentionally left blank. 


\section{WHC-SD-WM-CN-032, REV. O \\ ref WHC-SD-WM-SARR-001 REV O-A
SUPPLEMENT 1 \\ CONTENTS}

1.0 INTRODUCTION . . . . . . . . . . . . . . . . 139

2.0 OBJECTIVE AND SCOPE ................... 141

2.1 OBJECTIVE ............................ 141

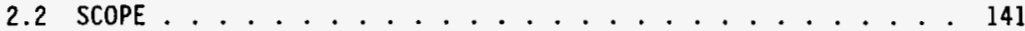

3.0 SUMMARY AND CONCLUSIONS . . . . . . . . . . . . . . 143

3.1 SUMMARY . . . . . . . . . . . . . . . . 143

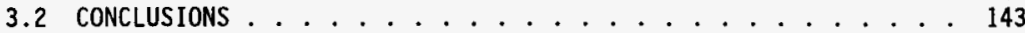

4.0 SUMMARY OF SOLVENT FIRE PHENOMENOLOGY . . . . . . . . . . . . . 145

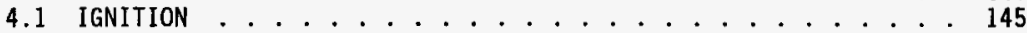

4.2 FIRE SPREAD RATE . . . . . . . . . . . . . 146

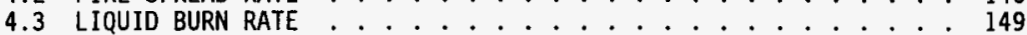

4.4 OXYGEN EXTINGUISHMENT OF POOL FIRES . . . . . . . . . . . . 149

4.5 HEAT OF COMBUSTION . . . . . . . . . . . . . 150

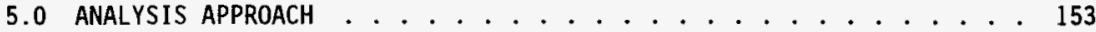

6.0 PREDICTED CONSEQUENCES OF SOLVENT FIRES . . . . . . . . . . 155

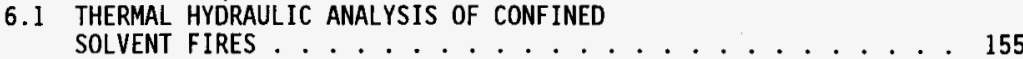

6.1.1 Combustion Energy ............... 155

6.1.2 Heat Transfer Rate from Gas to Surfaces . . . . . . . 158

6.1.4 Gas Venting Rate Under Pressure ............ 161

6.1 .5 Transient Pressurization Calculation ......... 165

6.1.6 Results of Thermal Hydraulic Analysis . . . . . . . 166

6.1.7 Conclusions from Thermal Hydraulic Analysis . . . . . 174

6.2 COMPARISON OF PREDICTED PRESSURES WITH

TANK STRUCTURAL LIMITS . . . . . . . . . . . . 175

6.2 .1 Tank Structural Limits . . . . . . . . . . . . 175

6.2 .2 Projected Solvent Fire ............. 176

6.2.3 Conclusions Regarding Tank Response
to Solvent Fires . . . . . . . . 177

to Solvent Fires

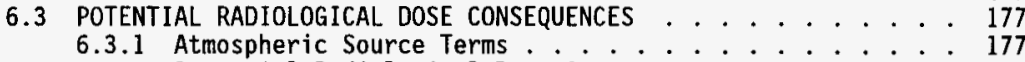

6.3.2 Potentia7 Radiological Dose Consequences . . . . . . 181

6.4 POTENTIAL TOXICOLOGICAL EXPOSURES . . . . . . . . . 182

6.4.1 Phosphorous Pentoxide . . . . . . . . . . 182

6.4 .2 Carbon Monoxide ................... 184

6.4 .3 Nitrogen Dioxide ................. 184

6.4 .4 Entrained Aqueous Waste ........... . 185

6.4.5 Comparison to Risk Acceptance Criteria . . . . . . . 185

7.0 REFERENCES . . . . . . . . . . . . . . . 191 
WHC-SD-WM-CN-032, REV. 0

ref. WHC-SD-WM-SARR-001 REV O-A
SUPPLEMENT 1

This page intentionally left blank. 


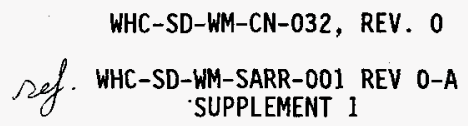

\subsection{INTRODUCTION}

This appendix presents an analysis of potential consequences of postulated pool fires in Tank $\mathrm{C}-103$. The organic liquid currently stored in this tank is of low flammability (NFPA Class III B) and a fire could be initiated only if a highly energetic ignition source were introduced. The probability of a pool fire event in Tank C-103 during interim storage was analyzed in report WHC-SD-WM-SARR-001 to be lower than $10^{-6} /$ year due to the imposition of operational controls to eliminate fire ignition sources. Because of the low probability of ignition, the consequences of postulated pool fires were not quantified in the report cited above.

The removal of supernatant liquids from Tank C-103 by means of salt well pumping could affect both the probability of solvent fire ignition, and the consequences of a postulated fire. This report section describes the results of an analysis of possible solvent fire consequences, along with the technical approach used to quantify the projected consequences. Of primary interest in this study is a comparison of consequences for the post-pumped waste configuration with those projected for the current waste configuration. 
WHC-SD-WM-CN-032, REV. 0

ref. WHC-SD-WM-SARR-001 REV O-A
SUPPLEMENT 1

This page intentionally left blank. 


\section{WHC-SD-WM-CN-032, REV. 0 \\ ry. WHC-SD-WM-SARR-001 REV O-A
SUPPLEMENT 1 \\ 2.0 OBJECTIVE AND SCOPE}

\subsection{OBJECTIVE}

The objective of work described in this appendix is to quantify possible consequences of postulated organic solvent fires in Tank $\mathrm{C}-103$. This information is intended to allow a comparison of solvent fire consequences for waste configurations before and after supernatant liquids are removed by salt well pumping, and thereby help evaluate any change in storage safety that may result from salt well pumping.

\subsection{SCOPE}

The scope of this evaluation is delineated by the following statements.

1. Waste and tank configurations of interest correspond to present conditions in Tank $\mathrm{C}-103$, and to projected conditions after salt well pumping.

2. Organic liquid is postulated to be ignited locally by an unspecified ignition source.

3. Consequences to be quantified include the following:

- potential structural damage to tank

- potential radiological exposure

- potential toxicological exposure

4. The organic liquid is postulated to be present as a pool or as an admixture with sludge.

5. This appendix evaluates consequences of solvent-air fires and does not consider condensed phase reactions. The latter were shown in Section 5 of the main body of this report to pose no credible hazard. 
WHC-SD-WM-CN-032, REV. 0

riff. WHC-SD-WM-SARR-001 REV O-A
SUPPLEMENT 1

This page intentionaliy left blank. 


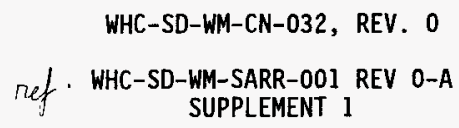

\subsection{SUMMARY AND CONCLUSIONS}

\subsection{SUMMARY}

Possible consequences of pool fires in Tank $\mathrm{C}-103$ were evaluated by carrying out the following work steps.

- Local ignition of the organic liquid in Tank $\mathrm{C}-103$ was postulated as a low probability initiating event.

- Pressurization of the tank due to the fire was analyzed by means of a transient energy and mass balance model. The analys is included a parametric study of the effect of uncertainties in key fire parameters.

- Predicted peak pressures were compared to tank structural limits to assess the potential for tank structural failure due to overpressure.

- Potential radiological consequence were evaluated by quantifying doses to onsite and offsite personnel assumed to be exposed to the smoke plume.

- Potential toxicological consequence were evaluated by quantifying airborne concentrations of phosphorous pentoxide, carbon monoxide and nitrogen dioxide in the smoke plume at onsite and offsite locations.

\subsection{CONCLUSIONS}

The work completed supports the following conclusions and summary statements.

1. A locally initiated pool fire is predicted to burn to oxygen extinguishment without causing overpressure failure of the tank. Approximately $60 \mathrm{~kg}$ of solvent is predicted to be oxidized prior to oxygen extinguishment.

2. Predicted peak pressure increases with solvent pool area up to an area of approximately $28 \mathrm{~m}^{2}$. This area corresponds to the predicted inflamed area at the time of fire extinguishment. Therefore postulated pool fires in pre- and post-pumped tank conditions are predicted to have similar consequences unless solvent pool area after salt well pumping is smaller than $28 \mathrm{~m}^{2}$. 


\section{WHC-SD-WM-CN-032, REV. 0 \\ ref. WHC-SD-WM-SARR-OO1 REV O-A}

3. Fire spread velocity was identified as the most sensitive parameter in determining predicted peak pressure. For large pools the predicted peak pressure for a spread rate of $2 \mathrm{~cm} / \mathrm{s}$ is $11.9 \mathrm{psig}$ $(82.1 \mathrm{kPa})$ as compared to a peak pressure of $8.5 \mathrm{psig}(58.6 \mathrm{kPa})$ predicted using a best-estimate spread rate of $1 \mathrm{~cm} / \mathrm{s}$. These peak pressures are lower than the estimated tank structural limit of 14 psig $(96.5 \mathrm{kPa})$.

4. Predicted dose consequence for contained fires which burn $60 \mathrm{~kg}$ of solvent are below risk guidelines for anticipated events.

5. Peak concentrations of $\mathrm{P}_{2} \mathrm{O}_{5}, \mathrm{CO}$, and $\mathrm{NO}_{2}$ are below guidelines for both onsite and offsite receptors. 
WHC-SD-WM-CN-032, REV. 0

\section{ref. WHC-SD-WM-SARR-001 REV 0-A
SUPPLEMENT 1}

\subsection{SUMMARY OF SOLVENT FIRE PHENOMENOLOGY}

In this section key phenomena expected to govern the rate of energy production by a postulated solvent fire in Tank $\mathrm{C}-103$ are reviewed. The objective is to describe a technical basis for quantifying the energy production rates used to predict tank pressurization in Section 6.0 .

\subsection{IGNITION}

The oxidation reaction that occurs when liquids or solids burn takes place in the gas phase. Ignition requires that the combustible materia] be heated to a temperature sufficiently high to produce a fuel-air mixture that is flammable. The flash point of a flammable material is the temperature at which vapors in equilibrium with the material and its air space reach the lower flammability limit or LFL in air. A spark introduced into combustible vapors at the LFL can ignite a gas phase deflagration that is perceived as a "flash". The "flash" that can be observed at the flash point is typically not energetic enough to cause additional fuel to vaporize and support a steady flame. A higher temperature, called the "fire point" is required for sustained combustion. As an example, flash point and fire point for dodecane are Tisted as $74^{\circ} \mathrm{C}$ and $103^{\circ} \mathrm{C}$ respectively by Thorne (1983). Thus for dodecane, an organic liquid that bears chemical similarity to the solvent in Tank $\mathrm{C}-103$, the fire point is approximate $1 \mathrm{y} 30^{\circ} \mathrm{C}$ higher than the flash point. The measured flash point of the $\mathrm{C}-103$ solvent is $118 \pm 1^{\circ} \mathrm{C}$ (Pool and Bean $1994)$, suggesting a fire point of approximately $118+30$ or $148^{\circ} \mathrm{C}$. Thus $\mathrm{C}-103$ solvent would be expected to support a continuing flame only if heated by more than $100^{\circ} \mathrm{C}$ from its current temperature of $40^{\circ} \mathrm{C}$.

For open pools of liquids that are highly subcooled compared to the flash point, ignition by a local energy source is difficult. Experiments reported in Flame Spreading Across Liquid Fuels (G1assman and Dryer 1981) showed a high flash point liquid could not be ignited by a torch placed directly on the fuel. In large scale tests of solvent fires liquid pools were ignited after confined regions of liquid were warmed by electrical heaters (Malet et al. 1983). An analysis of required ignition energy for open pools (Postma et a1. 1994 ) indicated that an energy source of $1.2 \mathrm{MJ}$ delivered over a time period of minutes would be required to ignite the organic solvent in tank $\mathrm{C}-103$.

Solid fuels or liquids fuels containing wicks can be more easily ignited than open liquid pools: The reason is that solids can not dissipate heat applied locally by means of convective flows. Because solid fuels may be more easily ignited than open liquid pools, the potential for more easily ignitable sludge/solvent admixtures in Tank $\mathrm{C}-103$ following salt well pumping must be evaluated.

Another factor that must be considered in the ignition of liquids is the presence of water vapor in the fuel-air mixture. Water is an inert diluent, which if present in mole fractions greater than approximately $30 \%$ 
WHC-SD-WM-CN-032, REV. 0

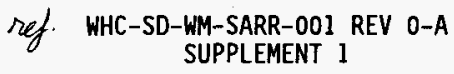

(Burger 1956), will render the fuel-air mixture inert. This inerting effect of water is of particular interest for solvent/sludge admixtures that contain appreciable moisture contents.

In summary, the ignition of a solvent fire requires that a flammable airfuel mixture be created, that an ignition source be present, and that fuel and flame conditions satisfy the requirement that energy transfer from the flame be sufficient to vaporize fuel at a rate fast enough to support a steady flame.

In the fire analyses studied in this report section it is postulated that a steady flame is ignited over an arbitrarily specified area. The probability of ignition, for a particular fuel/sludge/air configuration is evaluated elsewhere in this report.

\subsection{FIRE SPREAD RATE}

A locally ignited fire can spread if the energy from the burning zone can heat adjoining fuel surfaces to temperatures above the flash point. The spread rate is important in postulated fires in Tank C-103 because the rate of energy production by a fire is proportional to the inflamed surface area. The energy production affects tank pressurization resulting from a solvent fire.

Currently, no generally accepted model or correlation exists for easy use in predicting flame spreading rates. In a review of the topic, Quintiere (1988) notes that for liquid temperatures below the flash point, liquid phase effects control and for temperatures above the flash point, gas phase effects control. This is illustrated graphically in Figure 4.1. As indicated, the spread rate is low and increases with temperature until the liquid is heated to the flash point. Studies of flame spreading rates (Glassman and Dryer 1980, Akita 1973) indicate that liquid properties (surface tension, viscosity) are of prime importance in this low temperature region. Above the flash point the spread rate increases to a maximum that is controlled by flame speeds for premixed vapors. The maximum spread velocity was stated by Glassman and Dryer (1980) to be four to five times the laminar burn velocity and is attained when liquid temperature is high enough to generate vapors which form a stoichiometric mixture above the pool.

For Tank $\mathrm{C}-103$, solvent temperatures are sub-cooled by approximately $78^{\circ} \mathrm{C}$ (118-40) compared to the flash point, so liquid properties would control spread rate.

Experimental measurements of spread rates can be used as a basis for estimating spread rates for postulated pool burning in Tank $\mathrm{C}-103$ solvent. Glassman and Dryer (1980) measured spread rates of kerosene floating on water at room temperature to vary from 0.5 to $1.3 \mathrm{~cm} / \mathrm{s}$ depending on viscosity. Viscosity was controlled in the experiments by mixing the kerosene with a thickening agent (polyisobutylene). The break point in viscosity was at approximately five centipoise; for lower viscosities (the viscosity of C-103 
WHC-SD-WM-CN-032, REV. 0

ref. WHC-SD-WM-SARR-001 REV O-A
SUPPLEMENT 1

Figure 4.1 Effect of Liquid Temperature on Flame Spread Rate (G1 assman and Dryer 1980).

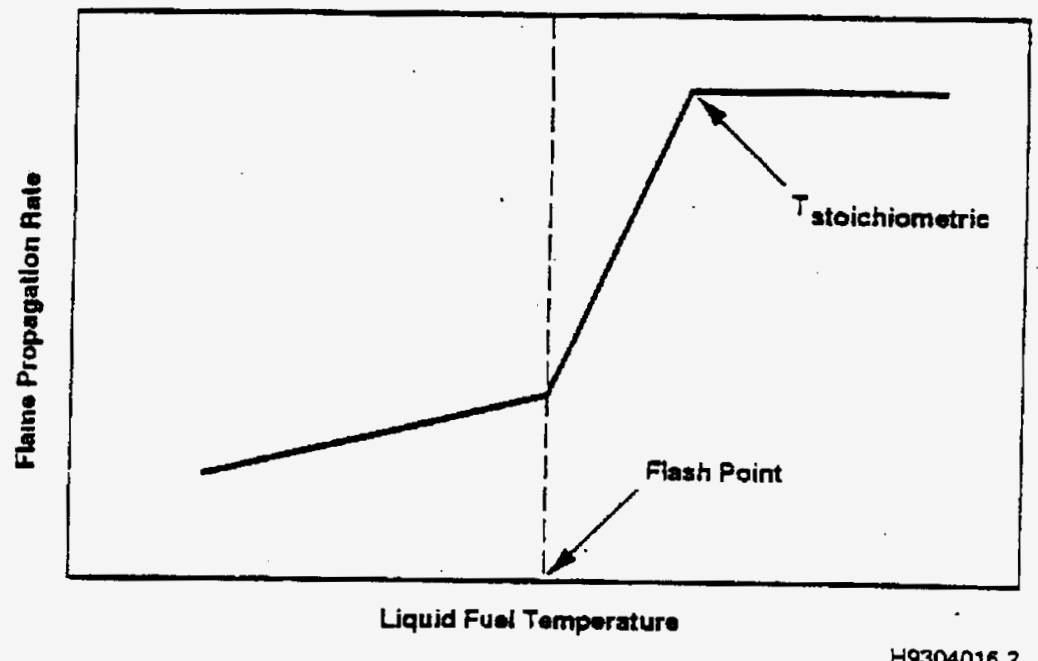




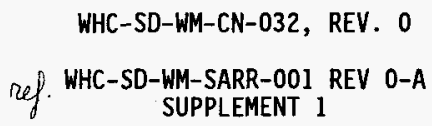

solvent is 2.5 centipoise) the spread rate was approximately $1.3 \mathrm{~cm} / \mathrm{s}$. The closed cup flash point of kerosene is reported as $49^{\circ} \mathrm{C}$ (NFPA 1988) so the kerosene tested was subcooled by roughly $(49-20)$ or $29^{\circ} \mathrm{C}$.

Fire spread rates for kerosene/solid admixtures were measured in Flame Spread Over Porous Solids Soaked With a Combustible Liquid (Takeno and Hirano 1986). The highest spread rate $(\sim 2 \mathrm{~cm} / \mathrm{s})$ was measured when the kerosene depth was $2.2 \mathrm{~cm}$ above the solids and exposed an open pool to the air atmosphere. The tests were carried out at room temperature so the degree of subcooling with respect to the flash point was similar to the value cited above $\left(29^{\circ} \mathrm{C}\right)$ for the tests of Glassman and Dryer (1980).

Malet et al. (1983) carried out large scale solvent pool fires in a closed compartment, and reported fire propagation times. The solvent (a mixture of TBP and NPH) was confined in pans that were $4 \mathrm{~m}^{2}$ in area and was ignited in a local region which was electrically heated. Propagation rates estimated from fire propagation times and pan sizes vary from $1.3 \mathrm{~cm} / \mathrm{s}$ to $3.3 \mathrm{~cm} / \mathrm{s}$ depending on mean pool temperature. The lower rate, $1.3 \mathrm{~cm} / \mathrm{s}$, applies to a pool that had a mean temperature of $25^{\circ} \mathrm{C}$. The flash point of the solvents tested were not reported by Malet et al. (1983), but measurements reported by Pool and Bean (1994) for a 70/30 NPH/TBP mixture yielded a flash point of $101^{\circ} \mathrm{C}$. Using the $101^{\circ} \mathrm{C}$ flash point, the degree of subcooling for the $1.3 \mathrm{~cm} / \mathrm{s}$ spread rate is estimated to be $(101-25)$ or $74^{\circ} \mathrm{C}$. For the higher spread rate, $3.3 \mathrm{~cm} / \mathrm{s}$, the degree of subcooling is calculated to be $(101-53)=$ $48^{\circ} \mathrm{C}$.

The solvent pool in tank $\mathrm{C}-103$ is subcooled by $(118-40)$ or $78^{\circ} \mathrm{C}$ compared to its flash point. This degree of subcooling is greater than the subcooling in the tests described above. Because propagation rate decreases with an increase in the degree of subcooling, a flame spread rate of less than $1.3 \mathrm{~cm} / \mathrm{s}$ is expected for $\mathrm{C}-103$ solvent.

Following the salt well pumping of $\mathrm{C}-103$, it is possible that solvent could intrude into sludge. For such a case solvent fire propagation rates would be lower than for open pools because convective transport of heat in the solvent is greatly reduced. Takeno and Hirano (1986) studied the propagation rate of flames ignited over kerosene soaked into porous solids. The results showed that spread rate diminished significantly when the thickness of kerosene layer above the top of the solids was decreased. For a solids-free depth of $2.2 \mathrm{~cm}$, the propagation velocity, $\approx 2 \mathrm{~cm} / \mathrm{s}$, was similar to that of an open pool. When the solids free depth was reduced to $1 \mathrm{~mm}$, the spread rate decreased to $\sim 0.5 \mathrm{~cm} / \mathrm{s}$. For a liquid level equal to the solids level, the propagation rate varied according to the properties of the solids, but the highest rate measured was $0.1 \mathrm{~cm} / \mathrm{s}$, or roughly one twentieth of the open pool spread rate.

These test results of Takeno and Hirano (1986) are consistent with results reported by Hirano et a1. (1984) for flame spread over crude oil sludge. Measured flame spread rates in the later study varied from $0.02 \mathrm{~cm} / \mathrm{s}$ to $0.4 \mathrm{~cm} / \mathrm{s}$ depending on the quantity of $n$-hexane added to the sludge and the temperature of the sludge. 


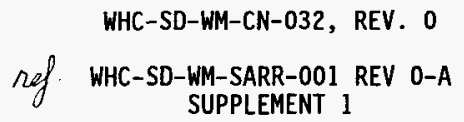

The relatively slow flame propagation rates for flammable liquids imbedded in solids are explainable in terms of heat transfer limitations from the flame front to adjacent non-burning material (Takeno and Hirano 1986, Hirano et al. 1984, Glassman and Dryer 1980). The same limitations are expected to apply to $\mathrm{C}-103$ solvent imbedded in sludge, and therefore flame front propagation rates in sludge/solvent admixtures are expected to be small compared to spread rates for an open pool of the same solvent.

\subsection{LIQUID BURN RATE}

The rate of thermal energy production by a pool or sludge fire is proportional to the burning rate per unit area. Therefore peak pressures that could be generated by fires in Tank C-103 are dependent on the burning rate.

Studies of burning rates indicate that for liquid pools, burning rate is governed by gas phase heat and mass transport rates. For liquid/solid admixtures, heat and mass transport in the solid can limit the burning rate. Burning rates for 1 iquid pools, expressed as $\mathrm{kg} / \mathrm{m}^{2} \mathrm{~min}$, increase with pool size to an asymptotic value for large pools. Babrauskas (1988) provides a correlating equation of the form:

$$
\dot{m}=\dot{m}_{0}\left(1-e^{k B D}\right)
$$

where

$$
\begin{aligned}
\dot{\mathrm{m}} & =\text { Burn rate, } \mathrm{kg} / \mathrm{m}^{2} \text { min } \\
\dot{m}_{\infty} & =\text { Burn rate for a large pool } \\
\mathrm{kB} & =A \text { constant, } \mathrm{m}^{-1} \\
D & =\text { Pool diameter }, \mathrm{m} .
\end{aligned}
$$

For kerosene the $\mathrm{kB}$ product is given by Babrauskas (1988) as $3.5 \mathrm{~m}^{-1}$, and based on Equation $4-1, i m$ reaches $95 \%$ of the maximum value for a pool $0.9 \mathrm{~m}$ in diameter. This projection, based on experimental data, indicates that data from pools roughly $1 \mathrm{~m}$ in diameter would apply reasonably to Tank C-103.

Large scale pool fire tests using kerosene/TBP mixtures have been carried out in Germany (Jordan and Lindner 1983) and in France (Malet et a). 1983). German tests evaluated the effect of size scale and confinement. French tests evaluated burning rate and the release of contaminants.

Jordan and Lindner (1983) concluded that burning rates increased with pool area; 1 ittle increase in burn rate was noted when burn area was increased from $0.8 \mathrm{~m}^{2}$ to $2 \mathrm{~m}^{2}$. This finding is as predicted from Equation (4-1). Jordan and Lindner (1983) also concluded that burning rates for fires in a closed containment ( $220 \mathrm{~m}^{3}$ in volume) were $40 \%$ to $50 \%$ lower than for fires in open air. Burning rates for large fires in closed containers are estimated at 1 to $1.2 \mathrm{~kg} / \mathrm{m}^{2}$ min from test results reported by Jordan and Lindner (1983).

The large scale tests reported by Malet et al. (1983) were carried out in a $400 \mathrm{~m}^{3}$ concrete enclosure and used pool areas of 0.4 to $4 \mathrm{~m}^{2}$. The enclosure 


\section{WHC-SD-WM-CN-032, REV. 0 \\ nef. WHC-SD-WM-SARR-001 REV O-A
SUPPLEMENT 1}

in these tests was vented to prevent pressure buildup. Mean combustion rates for nine tests ranged from $1.35 \mathrm{~kg} / \mathrm{m}^{2}$ min to $1.7 \mathrm{~kg} / \mathrm{m}^{2} \mathrm{~min}$. Based on the German and French test results, a solvent pool in Tank $\mathrm{C}-103$ would be expected to burn at a rate between $1 \mathrm{~kg} / \mathrm{m}^{2}$ min and $1.7 \mathrm{~kg} / \mathrm{m}^{2} \mathrm{~min}$.

Burning rates for combustible liquids soaked in inert solids are comparable to open pool burning rates as long as the solids wick the liquid to the surface (Wood et al. 1971). The tests of Wood et a]. (1971) showed that when the liquid-air interface fell below the top of a sand bed, the burning rate decreased. This behavior is as expected on the basis of additional resistance to heat and mass transfer caused by the porous bed. As applied to C-103 solvent/sludge admixtures, specific burn rates would be expected to be equal to or lower than burning rates for an open pool.

\subsection{OXYGEN EXTINGUISHMENT OF POOL FIRES}

Pool fires in non-ventilated compartments self-extinguish when oxygen concentration falls below the flammability limit for oxygen. For hydrocarbons, flame propagation is impossible in air-fuel mixtures which contain less than 14.5 volume percent oxygen (Lewis and Von Elbe 1987). This limit applies to air-fuel mixtures at one atmosphere pressure and room temperature.

Oxygen extinguishment levels for pool burning of NPH/TBP solvent in nonventilated compartments have been measured in large scale tests. Jordan and Lindner (1983) reported extinguishment levels of $11 \%$ to $17.5 \%$. A narrower range, $13 \%$ to $14.5 \%$ was reported by Malet et al. (1983) for nine large scale tests.

These results indicate that a solvent fire in Tank $\mathrm{C}-103$ would selfextinguish at an oxygen concentration in the range of $11 \%$ to $17.5 \%$. This self-extinguishment limits the mass of solvent that can be burned and thereby limits the thermal energy that can be generated by a solvent fire.

\subsection{HEAT OF COMBUSTION}

The C-103 solvent is composed mainly of hydrocarbons and TBP (Pool and Bean 1994). The combustion energy of the mix can be estimated by adding the contribution due to each of the two main components.

The heats of combustion of hydrocarbons are of a. similar magnitude, when expressed on a mass basis. For example, the heats of combustion of n-decane, $\mathrm{n}$-dodecane, and $\mathrm{n}$-hexadecane are calculated to be $47.6 \mathrm{MJ} / \mathrm{kg}, 47.5 \mathrm{MJ} / \mathrm{kg}$, and $47.2 \mathrm{MJ} / \mathrm{kg}$ respectively. The values cited above are changes in enthalpy for reactions with oxygen, starting with liquid fuel, and forming gaseous $\mathrm{CO}_{2}$ and 1 iquid $\mathrm{H}_{2} \mathrm{O}$, for a reaction temperature of $298^{\circ} \mathrm{K}$ (Lewis and Von Elbe 1987). Thus the combustion energy of hydrocarbons can be estimated on the basis of a representative component, such as dodecane. 


\section{WHC-SD-WM-CN-032, REV. 0 \\ ref. WHC-SD-WM-SARR-OOI REV O-A}

Heats of combustion of TBP and NPH were measured by Lee (1974) to be $28.2 \mathrm{MJ} / \mathrm{kg}$ and $44.0 \mathrm{MJ} / \mathrm{kg}$ respectively. These values, determined in a bomb calorimeter, indicate that the combustion energy of TBP is approximately $65 \%$ of the value for NPH.

The combustion energy of a mixture of NPH and TBP depends on the mass fraction of each component present in the burning zone. Vapor phase measurements reported by Pool and Bean (1994) for C-103 solvent indicate that approximately $16 \%$ of the vapor mass at $100^{\circ} \mathrm{C}$ is attributable to TBP (including DBBP with TBP) with the remainder being hydrocarbons. This vapor composition would apply to the solvent before an appreciable fraction had been burned. Because NPH is more volatile than TBP, its concentration would decrease with burn time, and the mix would become progressively enriched in TBP. This enrichment with burn time was observed in tests reported by Jorden and Lindner (1983). The enrichment in the solvent with TBP would cause a decrease in the combustion energy of the mix because TBP has the lower combustion energy of the two components. An upper bound estimate could be based on the initial value, and would be realistic for fires which self-extinguished before an appreciable fraction of the solvent was consumed.

Solvent pool fires result in incomplete combustion as evidenced by the dense smoke observed experimentally (Jordan and Lindner 1983, Ballinger et al. 1987). Therefore the thermal energy produced by a solvent fire will be lower than theoretical values based on complete reaction to form $\mathrm{H}_{2} \mathrm{O}$ and $\mathrm{CO}_{2}$. Combustion efficiencies (fraction of theoretical heat release) based on experimental results (Ayer et a1. 1988) vary from 0.35 for polyvinyl chloride to 1.0 for cellulose. For kerosene, Ayer et al. (1988) cite a combustion efficiency of 0.91 . TBP/NPH mixtures are expected to burn less efficiently than kerosene alone on the basis of the observed heavy smoke production from solvent fires. An upper bound estimate for combustion efficiency is the value cited for kerosene, 0.91 . 
WHC-SD-WM-CN-032, REV. 0

ref. WHC-SD-WM-SARR-001 REV 0-A
SUPPLEMENT 1

This page intentionally left blank. 


\section{WHC-SD-WM-CN-032, REV. 0 \\ ref. WHC-SD-WM-SARR-001 REV O-A
SUPPLEMENT 1}

5.0 ANALYSIS APPROACH

In this section, the analysis approach used to quantify potential consequences of solvent fires in Tank $C-103$ is summarized. The objective of this summary is to inform the reader of key assumptions that have been made in the analyses performed herein.

Step 1: Thermal Hydraulic Evaluation. The first step in this evaluation is to compute internal gas pressures that could result from solvent fires in Tank $\mathrm{C}-103$. As a beginning point it is postulated that a fire is ignited at a local site, and then spreads to surrounding fuel regions. Burning over the inflamed area is assumed to continue until the fire self-extinguishes at the oxygen extinguishment limit.

Uncertainties in fire and tank parameters have been quantified by performing a sensitivity analysis. This was done by defining a base case that uses best-estimate parameters to predict the peak pressure caused by a fire. Calculations were then performed in which key parameters were varied one at a time, to quantify how calculated peak pressure changed when the parameter changed over its expected range of possible values. By this means, it was possible to identify parameter ranges for which overpressure failure of the tank could occur. A comparison of parameters that lead to tank overpressure with the best estimate values for that parameter provides a basis for qualitative conclusions regarding the probability that a solvent fire could cause tank structural failure.

An assumption of the thermal hydraulic analysis is that the tank maintains structural integrity for all cases. No attempt has been made to account for the opening of leak paths caused by internal pressurization of the tank. This assumption likely causes the venting rate to be underestimated, and therefore the peak pressures to be overestimated. An in-depth structural analysis of the tank, risers, and cover plates would be required to quantify the role of leakage-under-pressure in mitigating tank structural failure.

Step 2: Comparison of Pressures With Tank Structural Limits. In Step 2, computed internal tank pressures are compared to tank structural capabilities. For cases where peak pressures do not exceed the analyzed pressure containment capability of the tank (Julyk 1994), the fire is assumed to burn to oxygen extinguishment. Following the end of burning, the contained atmosphere will cool and depressurize, eventually causing atmospheric air to enter tank. For the cases where structural integrity has been maintained, no additional solvent fires are postulated.

Step 3: Predict Radiological and Toxicological Consequences. Step 3 involves the prediction of potential dose and toxicological consequences. The airborne release of radionuclides is based on the inventory at risk multiplied by the aerosol release fraction. The inventory of radionuclides is based on analytical results from samples taken from Tank $\mathrm{C}-103$ and the aerosol release fraction is taken from recommended values based on experiments (Mishima 1994). For pool fire consequences where tank structural integrity is maintained, only a relatively small fraction of the organic liquid is burned, and consequently 


\section{WHC-SD-HM-CN-032, REV. 0 \\ ref. WHC-SD-WM-SARR-001 REV O-A
SUPPLEMENT 1}

only a small fraction of radionuclide inventory is at risk of being released to the tank atmosphere. Aerosol retention within the tank further diminishes the potential atmospheric source term for the intact tank case.

Toxicological consequences have been evaluated by quantifying release rates of $\mathrm{P}_{2} \mathrm{O}_{5}, \mathrm{CO}$, and $\mathrm{NO}_{2}$. Airborne concentrations of these species, predicted on the basis of applicable atmospheric dispersion factors, permit toxicological consequences to be quantified. 


\section{WHC-SD-WM-CN-032, REV. 0 ref. WHC-SD-WM-SARR-001 REV O-A
SUPPLEMENT 1 \\ 6.0 PREDICTED CONSEqUENCES OF SOLVENT FIRES}

In this section consequences that could result from postulated pool fires in Tank $\mathrm{C}-103$ are quantified. The evaluation considers a range of possible pool fire parameters, including pool area. Pool area is an important parameter because the pumpout of supernatant liquids is expected to result in residual pools that are small in comparison with the current (pre-pumped) configuration in which the pool covers the whole cross-sectional area of the tank. Consequences in three categories are considered in this study:

- potential for overpressure failure of tank

- potential radiological dose consequences

- potential toxicological exposures

\subsection{THERMAL HYDRAULIC ANALYSIS OF CONFINED SOLVENT FIRES}

Tank $\mathrm{C}-103$ is a gas tight structure except for several relatively small vent pipes. The combustion of fuels in the confined air volume would heat the air and thereby cause an increase in internal pressure. The peak pressure that can develop from a fire depends on how rapidly heat energy is evolved from the fire as compared to the rate at which energy can be dissipated through heat transfer to tank surfaces and by gas outflow through leak paths.

Internal gas pressure and temperature were computed as a function of time by performing energy and mass balances on the air inventory in the tank for relatively short ( $\sim 1 \mathrm{sec})$ time steps. Conditions at the end of a time step were used as initial conditions for the next step. Numerical evaluations were accomplished by means of a simple computer program written for this specific application. Algorithms used to quantify important parameters in the energy and mass balances are described as follows.

\subsubsection{Combustion Energy}

The rate of energy production by a solvent fire was computed as the product of specific combustion energy, inflamed area, and specific burning rate:

$$
Q_{\text {comb }}=\Delta H_{c} \cdot A_{f} \cdot \dot{m}_{b}
$$

where

$$
\begin{aligned}
Q_{c o g} & =\text { Combustion energy rate, } \mathrm{J} / \mathrm{c}, \\
\Delta \dot{A}_{c} & =\text { Specific combustion energy, } \mathrm{J} / \mathrm{kg}, \\
A_{f} & =\text { Inflamed area, } \mathrm{m}^{2}, \\
\dot{m}_{b} & =\text { Specified burn rate, } \mathrm{kg} / \mathrm{m}^{2} \mathrm{~s} .
\end{aligned}
$$

The combustion energy quantified by Equation (6-1) was assumed to be added to 


\section{WHC-SD-WM-CN-032, REV. 0 \\ ref. WHC-SD-WM-SARR-001 REV O-A
SUPPLEMENT 1}

the gas phase as sensible heat energy. The increase in sensible heat caused an increase in gas temperature and pressure and an increase in heat transfer rate from the gas to surfaces in the tank, as quantified in the Sections 6.1.2 and 6.1 .3 that follow.

6.1.1.1 Specific Combustion Energy. The change in enthalpy for combustion, $\Delta H_{c}$ is a constant for a specific case. It was assigned values on the basis of theoretical values for a complete reaction, multiplied by an efficiency

factor. The theoretical value was calculated as the weighted sum of combustion energies for NPH and for TBP:

$$
\Delta H_{c}=0.84 \Delta H_{c}(\mathrm{NPH})+0.16 \Delta H_{c}(\mathrm{TBP})
$$

The combustion enthalpy for $\mathrm{NPH}$, was taken equal to the value for $n$-dodecane. $\Delta \mathrm{H}_{\mathrm{c}}$ for $\mathrm{n}$-dodecane, computed from a combustion enthalpy value given by Lewis and Von Elbe (1987) is $44.1 \mathrm{MJ} / \mathrm{kg}$. The combustion ethalpy for TBP was computed from bomb calorimetry analyses (Lee 1974), and amounts to $26.5 \mathrm{MJ} / \mathrm{kg}$.

The mass fractions of NPH and TBP 1isted in Equation (6-2), $(0.84$ and 0.16 ) were based on vapor phase mass concentrations at $100^{\circ} \mathrm{C}$ (Pool and Bean 1994). Increases in the fraction of TBP that would occur as a fire continued (depletion of volatile species) was neglected. This is conservative because combustion energy of NPH is higher than that of TBP. The theoretical value for combustion enthalpy is thus:

$$
\Delta H_{c}=0.84(44.1)+0.16(26.5)=41.3 \mathrm{MJ} / \mathrm{kg} \text {. }
$$

A best-estimate combustion efficiency of $80 \%$ was assigned on the basis of a range of values cited by Ayer et al. 1988 for fire accidents in nuclear fuel cycle facilities. Parametric runs were made using combustion efficiencies of $70 \%$ and $91 \%$. The higher efficiency (91\%) was cited by Ayer et al. (1988) as a value applicable to pools of kerosene. The base case combustion energy is $0.8(41.3)=33 \mathrm{MJ} / \mathrm{kg}$; higher and lower values used in the sensitivity analysis were $\quad 37.6 \mathrm{MJ} / \mathrm{kg}$ and $28.9 \mathrm{MJ} / \mathrm{kg}$ respectively.

6.1.1.2 Inflamed Area. Inflamed area was computed as a function of $t$ ime on the basis of an arbitrarily assigned initial inflamed area and a spread rate. Circular geometry was assumed, leading to the following expression for the radius of the inflamed region:

$$
R_{f}=R_{o}+V_{s} t
$$

where

$$
\begin{aligned}
R_{f} & =\text { radius of inflamed circle, } m, \\
R_{o} & =\text { initial inflamed area, } m, \\
V_{s} & =\text { spread velocity, cm/s, } \\
t & =\text { time from fire ignition, } s .
\end{aligned}
$$




\section{WHC-SD-WM-CN-032, REV. 0 \\ ref. WHC-SD-WM-SARR-001 REV O-A
SUPPLEMENT 1}

$R_{0}$ was arbitrarily assigned a value of $0.15 \mathrm{~m}(0.5 \mathrm{ft}$.$) for the base case, and$ parametric runs were made with $R_{0}$ values that were double and half the base case value. The technical basis for starting the fire in a localized area is that ignition of a large pool area is extremely improbable, as discussed in Section 4.1 .

An upper limit to $R_{f}$ was computed for each case analyzed on the basis of a prescribed solvent/air interfacial area. For the prepumped waste configuration the solvent pool covers the whole tank area of $411 \mathrm{~m}^{2}$. After salt well pumping, only a fraction of the waste surface would be covered by solvent. The solvent/air interfacial area in the post-pumped tank was evaluated on a parametric basis, with a base case value of $10 \%$ of the tank cross-sectional area. Sensitivity analyses were performed for a broad range of solvent areas.

Flame spread velocity over liquid pools can be related to the degree to which the pool is subcooled with respect to the flash point, as discussed in Section 4.2. For C-103 solvent, a spread velocity of less than $1.3 \mathrm{~cm} / \mathrm{s}$ is expected, so a base case velocity of $1.0 \mathrm{~cm} / \mathrm{s}$ was assigned. Sensitivity analysis cases were run using spread velocities of $0.1 \mathrm{~cm} / \mathrm{s}, 0.5 \mathrm{~cm} / \mathrm{s}$ and $2.0 \mathrm{~cm} / \mathrm{s}$.

Flame spread velocities over solids are slow compared to liquids, as discussed in Section 4.2. Tests performed by Takeno and Hirano (1986) showed that spread velocity $\mathrm{fell}$ from $-2 \mathrm{~cm} / \mathrm{s}$ to $0.5 \mathrm{~cm} / \mathrm{s}$ when kerosene depth was lowered from $2.2 \mathrm{~cm}$ to $0.1 \mathrm{~cm}$. Spread velocity fell further to $0.1 \mathrm{~cm} / \mathrm{s}$ when the liquid interface was at the solid/air interface. Based on these test results, a best estimate spread velocity over solvent/sludge surfaces would be $0.1 \mathrm{~cm} / \mathrm{s}$ or less. Because spread velocities of $0.5 \mathrm{~cm} / \mathrm{s}$ or lower lead to low calculated tank pressures, the burning of solvent imbedded in inert solids is comparatively less important than liquid pool fires.

6.1.1.3 Specific Burn Rate. Available test data on the burning of solvent pools, discussed in Section 4.3 , define a range of 1 to $1.7 \mathrm{~kg} / \mathrm{m}^{2} \mathrm{~min}$ for large pools in confined volumes. A base case burn rate of $1.2 \mathrm{~kg} / \mathrm{m}^{2} \mathrm{~min}$ was selected on the basis of large scale German tests (Jordan and Lindner 1983) in a closed containment. Sensitivity calculations were performed using burning rates of $1.0 \mathrm{~kg} / \mathrm{m}^{2} \mathrm{~min}$ and $1.7 \mathrm{~kg} / \mathrm{m}^{2}$ min to cover the range cited above.

Burning rate would be expected to decrease as oxygen concentration decreases during the course of a fire (Ayer et al. 1988). This reduction in burning rate, if quantified, would lower computed peak pressures. The inclusion of a time-variable burning rate that accounts for oxygen depletion is beyond the scope of the current analysis. The use of a constant burning rate, as done herein, introduces an unquantified degree of conservatism into the mode1. 


\section{WHC-SD-WM-CN-032, REV. 0 \\ ref. WHC-SD-WM-SARR-001 REV O-A
SUPPLEMENT 1}

\subsubsection{Heat Transfer Rate from Gas to Surfaces}

Sensible heat transfer from the gas to tank surfaces would occur by radiation and convection. Key simplifying assumptions made to model the heat transfer rate from the flame to surrounding gas and from gas to surfaces are:

- the bulk of the gas was assumed to be well-mixed,

- flame radiation directly to the inflamed solvent was accounted for, but radiation from the $f 7$ ame in other directions was assumed to be absorbed by the bulk gas phase.

These assumptions cause the model to underpredict heat transfer by radiation because radiation heat transfer rate increases with the fourth power of absolute temperature. Radiation from regions of higher than average temperature would more than offset the reduction in radiation from lower than average temperature. The additional modeling required to more accurately account for $\mathrm{flame}$ radiation is beyond the scope of this analysis. As a result, the current model will yield conservative estimates of peak pressures.

6.1.3.1 Heat Transfer from Flame to Fuel Surface. Heat transfer from flame to the unburned fuel surface provides the energy to volatilize liquid and/or solid fuels and thereby maintain an ongoing flame. Results of empirical studies of $f l$ ame heat transfer can be used to estimate values for application to solvent fires in Tank C-103. Shinotake et al. 1985 measured the surface heat flux for a heptane pool fire in a burn pan $1 \mathrm{~m}$ in diameter. Heat fluxes at the center of the pan peaked at approximately $50 \mathrm{kw} / \mathrm{m}^{2}$ at early times and then held constant at approximately $35 \mathrm{kw} / \mathrm{m}^{2}$ for the duration of the fire. Similar behavior was observed at a radial distance $0.4 \mathrm{~m}$ from the center of the pan, but the heat flux was lower, approximately $30 \mathrm{kw} / \mathrm{m}^{2}$. Wood et al. (1971) measured fluxes of a similar magnitude for acetone fires. These measured values compare we1l with a handbook value for kerosene of $24.5 \mathrm{kw} / \mathrm{m}^{2}$ (Ayer et a1. 1988). For solvent fires, a higher radiation heat transfer rate would be expected as compared to pure kerosene because of the higher smoke yield in solvent fires (Jordan and Lindner 1983). The handbook value for the burning of rubber gloves is $72 \mathrm{kw} / \mathrm{m}^{2}$ (Ayer et a1. 1988) reflecting the much higher soot production from rubber gloves. Soot particles increase the heat transfer rate because they serve as radiators (Siegel and Howe11 1989).

For solvent fires, a best-estimate heat transfer flux of $57 \mathrm{kw} / \mathrm{m}^{2}$ was arrived at by interpolating between handbook values of $24.5 \mathrm{kw} / \mathrm{ft}^{2}$ for kerosene and $72 \mathrm{kw} / \mathrm{ft}^{2}$ for rubber gloves on the bas is of the fraction of fuel carried off in the form of soot particles. Analysis were also made with heat fluxes of $24.5 \mathrm{kw} / \mathrm{m}^{2}$ and $72 \mathrm{kw} / \mathrm{m}^{2}$ to $i 17$ ustrate the sensitivity of computed pressure to this parameter.

Radiant heat fluxs to horizontal surfaces outside the inflamed area are appreciable (Yamaguchi and Wakasa) but have been neglected because realistic treatment is beyond the scope of this analysis. This neglect of a heat transfer path is conservative with respect to predicted peak pressure.

\subsubsection{Radiation Heat Transfer from Bulk Gas to Tank Surfaces. The rate of}




\section{WHC-SD-WM-CN-032, REV. O \\ ref. WHC-SD-WM-SARR-001 REV O-A
SUPPLEMENT 1}

thermal radiation loss from the gas phase to enclosing tank surfaces was computed by means of the following equation:

$$
\frac{q_{r}}{A}=\sigma \epsilon_{g}\left(T_{g}^{4}-T_{s}^{4}\right) \epsilon_{s}
$$

where

$$
\begin{aligned}
\mathrm{q}_{\mathrm{f}} & =\text { heat transfer rate due to radiation, } \\
\mathrm{A} & =\text { surface area, } \\
\sigma & =\text { Stefan-Boltzman constant, } \\
\dot{\epsilon}_{\mathrm{g}} & =\text { emissivity of gas, } \\
\mathrm{T}_{\mathrm{g}} & =\text { absolute temperature of gas, } \\
\mathrm{T}_{\mathrm{s}} & =\text { absolute temperature of surface, } \\
\epsilon_{\mathrm{s}} & =\text { emissivity of surface. }
\end{aligned}
$$

The emissivity of the gas was estimated from values of the product of mean beam length and the concentration of emitting species in the gas. Mean beam length was estimated using data for a rectangular parallelepiped with radiation to all faces (McAdams 1954); a mean beam length of $8.1 \mathrm{~m}$ was predicted on this basis. Emitting species in the gas phase for this problem include $\mathrm{H}_{2} \mathrm{O}, \mathrm{CO}_{2}$, and soot particles. Initially, before a fire is ignited, water vapor with be the main emitting specie, and for saturated vapor at $40^{\circ} \mathrm{C}$, $\epsilon_{g}$ is estimated from a correlation presented by McAdams (1954) to be 0.34 .

After a fire is ignited, soot particles will significantly increase the emissivity of the gas. The emissivity of soot particles was estimated as follows. First, the concentration of airborne particles can be estimated from the mass of solvent burned and the fraction emitted as soot. At the point of oxygen extinguishment ( 13 volume $\% 0_{2}$ ) stoichiometric calculations indicate that roughly $60 \mathrm{~kg}$ of solvent will be burned. Based on an aerosol production of 15\% of the solvent combusted (Jordan and Lindner 1983) and a gas phase volume of $2660 \mathrm{~m}^{3}$, the concentration of aerosol is $60 \times 0.15 / 2660$ or $3.38 \mathrm{E}-3$ $\mathrm{kg} / \mathrm{m}^{3}$. The volume fraction of aerosol, calculated for a density of $870 \mathrm{~kg} / \mathrm{m}^{3}$ (the solvent density), is $3.38 \mathrm{E}-3 / 870$ or $3.89 \mathrm{E}-6$. The volume fraction multiplied by mean beam length of $8.1 \mathrm{~m}$ is thus $3.15 \mathrm{E}-5$. This concentrationbeam length product is large compared to values needed to attain an emissivity of approximately unity (Siegel and Howell 1989) for a gas-soot suspension at $1600^{\circ} \mathrm{K}$. Based on a graphical correlation presented by Siegel and Howe 11 (1989), the emissivity of soot alone is greater than 0.5 for soot concentration-path length products greater than $1 \mathrm{E}-6 \mathrm{~m}$, for temperatures equal to or greater than $750^{\circ} \mathrm{K}$. Adding soot and water emissivities, total emissivity would be larger than approximately $0.84(0.5+30.4)$ for tank atmospheres containing only $0.3 \%$ of the aerosol predicted at the end of the fire. Thus it is concluded that a realistic estimate for gas emissivity for a solvent fire in Tank $\mathrm{C}-103$ is unity.

The emissivities of tank wall, solvent, and exposed sludge surfaces are expected to be in the range of 0.9 to 1.0 on the basis of typical values cited by McAdams (1954). 


\section{WHC-SD-WM-CN-032, REV. 0 \\ $r y$. WHC-SD-WM-SARR-001 REV O-A
SUPPLEMENT 1}

Best-estimate radiation heat transfer rates were based on a $\epsilon_{\mathrm{g}} \cdot \epsilon_{\mathrm{s}}$ product of 0.9 . Analyses were also done with emissivity products $\left(\epsilon_{\mathrm{g}} \cdot \epsilon_{\mathrm{s}}\right)$ of $\delta .8$ and 1.0 to illustrate the sensitivity of predicted peak pressure to this parameter.

6.1.3.3 Convection Heat Transfer from Bulk Gas to Tank Surfaces. Convection heat transfer was computed by means of a heat transfer coefficient and temperature difference:

$$
q_{c}=h_{c} A\left(T_{g}-T_{s}\right)
$$

where

$$
\begin{aligned}
& q_{c}=\text { heat transfer rate due to convection, } \\
& h_{c}=\text { convection coefficient. }
\end{aligned}
$$

The convection coefficient, $h_{c}$, was estimated from a correlation presented by McAdams (1954):

$$
\frac{h_{c} L}{k_{f}}=0.13[\mathrm{Gr} \mathrm{Pr}]^{1 / 3}
$$

where

$$
\begin{aligned}
& L=\text { length dimension of surface, } \\
& K_{f}=\text { thermal conductivity of gas evaluated at film temperature, } \\
& G r=\text { Grashov No. evaluated at film properties, } \\
& \mathrm{Pr}=\text { Prandt } 1 \text { No. evaluated at film properties. }
\end{aligned}
$$

The overall heat loss rate from the gas to tank surfaces is the sum of that due to radiation and convection:

$$
q_{w}=q_{r}+q_{c}
$$

6.1.3.4 Surface Areas for Heat Transfer. Surface areas for heat transfer from the bulk gas phase were estimated from tank geometry, and are summarized as follows.

The tank dome and a small segment of the cylindrical wall have exposed concrete surfaces. The areas were estimated to total $476 \mathrm{~m}^{2}$. Steel sheeting covers the cylindrical walls from above the cascade pipe to the waste surface. Internal piping and risers also expose steel surfaces to the gas phase. Total steel area was estimated as exposed wall area plus $10 \%$ to account for internal tank structures. The total steel surface area was estimated at $337 \mathrm{~m}^{2}$. Waste area was evaluated as the cross-sectional area of the tank, $411 \mathrm{~m}^{2}$, For the post-pumped waste configuration, solvent was assumed to cover only a fraction 


\section{WHC-SD-WM-CN-032, REV. 0 \\ ref. WHC-SD-WM-SARR-001 REV O-A
SUPPLEMENT 1}

(assigned on a parametric basis) of the waste surface. Sludge area was computed as the tank area $\left(411 \mathrm{~m}^{2}\right)$ minus solvent pool area.

6.1.3.5 Surface Temperature Calculation. Surface temperatures were computed as a function of time by solving the transient heat conduction equations in one dimension for exposed concrete and sludge. The algorithm used for this task is described by Fox et al. (1991). Steel temperatures were computed under the assumption that temperature gradients across 0.25 in $(6.35 \mathrm{~mm})$ thick sheets were negligible. Likewise, solvent pools were assumed to be thermally well-mixed.

\subsubsection{Gas Venting Rate Under Pressure}

The venting of gases during solvent fire mitigates pressure buildup as compared to a leak-tight vessel. Studies of available information has identified a number of known leak paths, and these are described as follows.

6.1.4.1 Pit Drains. Tank $C-103$ has three access pits, each of which is equipped with a floor drain (Postma et al. 1994). The drain line is a sloped, 2-in. Sch. 40 steel pipe. The inlet is in the bottom of a cubical cavity in the floor of the pit. The outlet terminates in a riser having a diameter that is large compared to the drain line. Two of the pits have drain lines that are approximately $2 \mathrm{ft} .(0.61 \mathrm{~m})$ in length, and the third has a drain that is approximately $5 \mathrm{ft}$. $(1.52 \mathrm{~m})$ in length.

Gases forced from a pressurized tank would enter the pipes, pressurize the pits, and then lift the cover blocks. Internal pressure required to 1 ift a cover block is small, amounting to approximately $0.26 \mathrm{psig}(1.8 \mathrm{Kpa})$ for a cover block thickness of $3 \mathrm{in} .(7.62 \mathrm{~cm})$.

The hydraulic resistance attributabie to the entrance effect is estimated to be equivalent to $5 \mathrm{ft}$. $(1.52 \mathrm{~m})$ of straight (Brown et al. 1950). Resistance at the outlet (the floor drain cavity) is modeled as a long sweep elbow, adding another $3 \mathrm{ft} .(0.92 \mathrm{~m})$ equivalent length of straight pipe (Brown et al. 1950). Based on these data, two pipes, each having flow areas of $0.0233 \mathrm{ft}^{2}\left(2.17 \mathrm{E}-3 \mathrm{~m}^{2}\right)$, can be modeled as pipes $10 \mathrm{ft}$. $(3.05 \mathrm{~m})$ in length. The third pipe, of the same flow area, has an equivalent length of $13 \mathrm{ft}$. $(3.96 \mathrm{~m})$.

6.1.4.2 U-Tube Seal Loop. A loop seal made of $1.5 \mathrm{in}$. Sch. 40 steel pipe is connected to a 4 in. pipe above grade. The loop is made from four $90^{\circ}$ elbows and short lengths of straight pipe that add to a total of approximately $1.5 \mathrm{ft}$. $(0.46 \mathrm{~m})$. The hydraulic resistance of each elbow is equivalent to a straight pipe length of $4.2 \mathrm{ft} .(1.28 \mathrm{~m})$ (Brown et al. 1950) so the equivalent length of the $U$-tube seal is $1.5+4(4.2)$ or $18.3 \mathrm{ft} .(5.58 \mathrm{~m})$. The internal cross-sectional area of this pipe is $0.01414 \mathrm{ft}^{2}\left(1.31 \mathrm{E}-3 \mathrm{~m}^{2}\right)$ (Perry, p. 415 , 1950).

6.1.4.3 Cascade Pipe to Tank C-102. A 3 in. Sch. 80 steel pipe connects the headspace of Tank $C-103$ to the headspace of Tank $C-102$. This pipe is approximately $50 \mathrm{ft}$. $(15.2 \mathrm{~m})$ in length. Flow resistance due to the Borda 


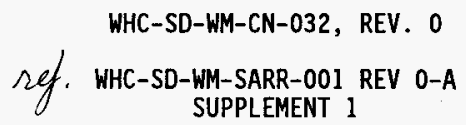

entrance (Brown et al. 1950) amounts to an additional $7 \mathrm{ft} .(2.19 \mathrm{~m})$, making the equivalent length equal to approximately $57 \mathrm{ft}$. (The internal crosssectional area of this pipe is $0.04587 \mathrm{ft}^{2}\left(4.26 \mathrm{E}-3 \mathrm{~m}^{2}\right)$ (Perry, p. 415, 1950).

6.1.4.4 Salt Well Riser. The salt well riser is a 10 in. Sch. 40 steel pipe that terminates in the heel pit. The upper flanged end of this riser is covered by a metal plate held in place by gravity. The plate, lead sheet $0.25 \mathrm{in} .(6.35 \mathrm{~mm})$ in thickness and $2 \mathrm{ft}$. $(0.61 \mathrm{~m})$ square would 1 ift under an internal pressure of approximately 1 psig $(6.89 \mathrm{Kpa})$ and pressurize the pit. The pit cover would then lift, allowing gas to vent by this route.

Installation of a salt well pump would block this vent path until higher headspace air pressures were reached. A pump assembly, weighing an estimated $500 \mathrm{lb} .(227 \mathrm{~kg})$, would be lifted at an internal tank pressure of approximately $7.4 \mathrm{psig}(51.1 \mathrm{Kpa}$ gage) for the case where the pump was in place. It should be noted that salt well pumps are not bolted or otherwise mechanically held in place, so upward movement, required to open this vent path is assured.

Flow resistance of this vent pipe, assuming the pump assembly has lifted because tank pressure exceeds the lift threshold, is estimated as follows. The length of the solid pipe is estimated at $20 \mathrm{ft}$. Below this length, the pipe is connected to a salt well screen. Two smaller pipes, 0.5 in. and $0.75 \mathrm{in}$. in nominal diameter are located inside the $10 \mathrm{in}$. pipe and occupy a small fraction of the flow area. The hydraulic radius (cross sectional area/wetted perimeter) is calculated to be 1.93 in. $(4.89 \mathrm{~cm})$ from which, the equivalent diameter (Perry, p. 378, 1950) is computed to be $4(1.93)=7.70$ in. $(19.6 \mathrm{~cm})$. While resistance to air flow through the screen portion of the 10 in. pipe would be small because of the large open area, pressure drop attributable to a Borda entrance, equivalent to a straight pipe length of approximately $18 \mathrm{ft}$. $(5.49 \mathrm{~m})$ (Brown et a1. 1950) is added to account for entrance effects. Exiting gas would undergo a $90^{\circ}$ change in direction as it flows between riser and pump flanges; resistance was modelled as a long sweep elbow, which adds $14 \mathrm{ft}$. $(4.27 \mathrm{~m})$ equivalent length of pipe. Flow resistance for this vent path is equivalent to that of a straight pipe having an inside diameter of $7.7 \mathrm{in}$. $(19.6 \mathrm{~cm})$ and a length of $20+18+14=52 \mathrm{ft}$. $(15.9 \mathrm{~m})$.

6.1.4.5 HEPA Filter Vent Line. The HEPA filter is connected to a 12 in. $(0.31 \mathrm{~m})$ riser through a section of $4 \mathrm{in}$. pipe. A butterfly valve in the section of 4 in. pipe allows the filter to be isolated from headspace air. The HEPA filter housing is connected by means of a 4 in. diameter plastic hose to a charcoal filter. This vent path would be available if the valve were in the open position during a tank pressurization incident. For pressure drops of a few psi, the HEPA filter would be blown out of its housing and likely be trapped in the charcoal filter, possibly plugging the flow path. Because of uncertainties in valve setting (open or closed) and flow path resistance under pressures that could develop under solvent fire conditions, this potential flow path has not been included in the analyses that follow.

6.1.4.6 Vent Flow Rate Estimation. Air flow velocities in vent pipes approach sonic velocities under the pressure gradients that could result from 


\section{WHC-SD-WM-CN-032, REV, 0 \\ ref. WHC-SD-WM-SARR-001 REV O-A
SUPPLEMENT 1}

a pool fire. Therefore flow rate estimates must account for compressibility effects.

Flow rate estimates were based on adiabatic flow of gases in ducts (Lapple 1943, Brown et a1. 1950). First, a resistance factor, $N$, is computed for each vent path.

$$
N=\frac{f L}{D}
$$

where

$$
\begin{aligned}
& f=\text { friction factor }, \\
& L=\text { pipe length, } \\
& D=\text { pipe diameter. }
\end{aligned}
$$

For fully developed turbulence (high Reynolds number) the friction factor is a function of the relative roughness of the pipe interior surface, (Brown et al. 1950). Estimated values of $N$ for the several vent paths considered herein are listed in Table 6.1.

Table 6.1 Flow Characteristics of Tank C-103 Vent Pipes.

\begin{tabular}{||l|c|c|c|c|}
\hline Vent Pipe Description & $\begin{array}{c}\text { Equivalent Length } \\
\mathrm{m}\end{array}$ & $\begin{array}{c}\text { Equivalent } \\
\text { Diameter } \\
\mathbf{m}\end{array}$ & $\begin{array}{c}\text { Friction } \\
\text { Factor } \\
\mathrm{f}\end{array}$ & $\frac{\mathrm{fL}}{\mathrm{D}}$ \\
\hline Pump Pit Drain & 3.05 & $5.25 \mathrm{E}-2$ & 0.018 & 1.05 \\
\hline Sluice Pit Drain & 3.05 & $5.25 \mathrm{E}-2$ & 0.018 & 1.05 \\
\hline Heel Pit Drain & 3.96 & $5.25 \mathrm{E}-2$ & 0.018 & 1.36 \\
\hline U-Tube Seal & 5.58 & $4.09 \mathrm{E}-2$ & 0.021 & 2.87 \\
\hline Cascade Pipe & 17.4 & $7.37 \mathrm{E}-2$ & 0.017 & 4.01 \\
\hline Salt Well Riser & 15.9 & 0.196 & 0.014 & 1.14 \\
\hline
\end{tabular}

Brown et al. 1950, for commercial steel roughness

A second step is the calculation of the ratio downstream pressure to upstream pressure:

$$
P R=\frac{P_{\text {atm }}}{P_{0}}
$$




\section{WHC-SD-WM-CN-032, REV. 0 \\ ref. WHC-SD-WM-SARR-001 REV O-A}

where

$$
\begin{aligned}
P R & =\text { pressure ratio, } \\
P_{a t m} & =\text { pressure in outside atmosphere, } \\
P_{0} & =\text { pressure in tank. }
\end{aligned}
$$

The pressure ratio is initially unity (tank at equilibrium with atmosphere) and has a calculated value of 0.51 at a tank pressure of 14 psig ( $96.5 \mathrm{Kpa}$ ), the maximum pressure the tank can safely withstand (Julyk 1994).

Based on pressure ratios, $P R$, and pipe resistance factor $N$ [from Equation (6-8)], a value of mass flow rate per unit area of flow path may be determined from the solution of the equations of adiabatic flow for compressible gas flow in pipes (Lapple 1943). Numerical results, presented in graphical form by Brown et al. 1950, allow one to determine $G / G_{\text {cri }}$ as functions of $N$ and $P R . ~ G$ is the mass flow velocity for the conditions of interest and $G_{\text {ni }}$ is the maximum mass flow velocity under isothermal conditions. The latter may be expressed in terms of upstream gas parameters (Brown et al. 1950):

$$
G_{c n i}=P_{0}\left(\frac{g_{c} M}{e R T_{0}}\right)^{1 / 2}
$$

where

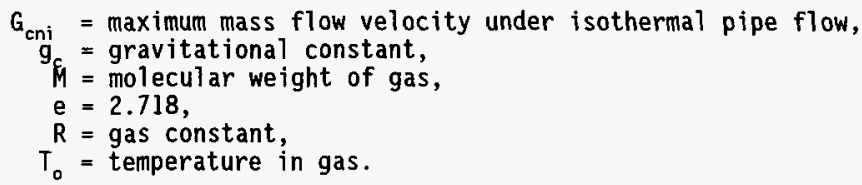

After $G$ is determined, the mass flow rate can be evaluated by multiplying by the flow area:

$$
\dot{\mathrm{m}}=\mathrm{G} \cdot \mathrm{A}
$$

where

$$
\begin{aligned}
& \dot{m}=\text { gas flow rate in pipe, } \mathrm{kg} / \mathrm{s}, \\
& G=\text { mass velocity, } \mathrm{kg} / \mathrm{m}^{2} \mathrm{~s} \\
& \dot{A}=\text { flow area, } \mathrm{m}^{2} .
\end{aligned}
$$

Results of the vent flow rate analysis are $i l l u s t r a t e d$ by results presented in Table 6.2. Flow rates through each of the vent paths, expressed in volumetric terms, computed for a tank pressure of $14 \mathrm{psig}(96.5 \mathrm{Kpa})$ and a temperature of $614^{\circ} \mathrm{K}$, are 1 isted in Table 6.2 . The stated temperature $\left(614^{\circ} \mathrm{K}\right)$ was computed as that required to increase tank pressure from its initial value to $14 \mathrm{psig}$ 
WHC-SD-WM-CN-032, REV. 0

ref. WHC-SD-WM-SARR-001 REV 0-A
SUPPLEMENT 1

(96.5 Kpa).

Table 6.2 Vent Flow Rates Calculated for a Tank Pressure of 14 psig $(96.5 \mathrm{Kpa})$

\begin{tabular}{||l|c|}
\hline \multicolumn{1}{|c|}{ Vent Pipe Description } & Vent Flow Rate $\mathrm{m}^{\mathrm{s}} / \mathrm{s}$ \\
\hline Pump Pit Drain & 0.46 \\
\hline Sluice Pit Drain & 0.46 \\
\hline Heel Pit Drain & 0.44 \\
\hline U-Tube Seal & 0.22 \\
\hline Cascade Pipe & 0.65 \\
\hline Salt Well Riser & 6.23 \\
\hline & \\
\hline
\end{tabular}

As indicated by the data of Table 6.2 , the salt well riser is the dominant flow path. The combined flow rate of the five small vents, $2.24 \mathrm{~m}^{3} / \mathrm{s}$, is roughly one-third of calculated flow rate for the salt well riser. A best estimate vent flow rate was based on the following assumptions:

- The five small vents 1 isted in Table 6.2 are open at all times,

- The salt well riser opens onty when the pump assembly is lifted by a tank pressure exceeding $7.4 \mathrm{psig}(51 \mathrm{Kpa})$.

An analysis of tank pressurization was also made under the assumption that the salt well riser did not open. This conservative case illustrates peak pressures that are predicted if only the small vents are considered.

A simple method for approximating the flow rate predicted from the adiabatic flow equation was used in the computer program used in this analysis. The orifice equation for gases (Perry, p. 403) was used along with an upper limit to velocity that limited orifice velocity to sonic velocity at the upstream temperature. This means for predicting outflow rates simplified the calculational scheme and yielded outflow rates that were within a few percent of those based on the adiabatic flow equations.

The opening of the salt well vent path was assumed to begin at a specified lift pressure and be completely open at the lift pressure plus 1 psi $(6.89 \mathrm{Kpa})$. Between these pressure limits flow area was linearly related to tank pressure.

\subsubsection{Transient Pressurization Calculation}

The buildup of pressure and temperature with time was computed using finite time steps as contrasted with a numerical solution to the governing differential equations. This approach was adopted because it permitted easy coupling of the available surface heat transfer model with gas phase mass and energy balances, and yielded an analysis tool that allowed numerous specific cases to be analyzed with minimal investment of time and money. The energy 


\section{WHC-SD-WM-CN-032, REV. 0 ref. WHC-SD-WM-SARR-OOI REV O-A
SUPPLEMENT 1}

and mass conservation equations were solved in a series of thermodynamic process steps for each time increment. These steps are described as follows.

Step 1: Combustion Energy and Stoichiometry. In Step 1, the combustion energy produced by the fire was computed using Equation (6-1). Stoichiometric calculations were then carried out to determine gas composition at the end of the time step. The stoichiometric calculations were based on the reaction of dodecane and TBP to form $\mathrm{CO}_{2}$ and $\mathrm{H}_{2} \mathrm{O}$ as gases. Gaseous unburned fue 7 amounted to a very small mole fraction in the gas phase and was neglected in computing bulk, as composition and inventory.

Step 2: Gas Heatup at Constant Volume. In Step 2 the internal energy of the gas inventory was increased by the quantity of combustion energy calculated in Step 1. Heat capacity for each component gas was computed as a function of temperature using the quadratic coefficients published by Hougen and Watson - 1954. Heat capacity at constant volume, $C_{v}$, was computed by subtracting the gas constant, $R$, from the heat capacity at constant pressure.

Step 3: Gas Venting and Flow Work. Gas outflow rate was computed from the pressure difference between the tank and the outside air as described in section 6.1.3. The gas in the tank was assumed to undergo an isentropic expansion. The expanded volume was computed as the sum of tank headspace volume and vented gas volume. The inventory of gaseous species in the tank was then reduced by the fractional volume lost by venting.

Step 4: Heat Transfer to Surfaces. Heat transfer from the gas to tank surfaces was computed using the methodology described in Section 6.1.2. Gas volume and inventory were held constant for this step. Temperature, pressure, and gas inventory computed at the end of this step were used as initial values for the next time increment, starting again at Step 1. The oxygen mole fraction was compared to the prescribed extinguishment level, and combustion was halted if this level was reached.

\subsubsection{Results of Thermal Hydraulic Analysis}

Peak pressure generated by a pool fire in Tank $\mathrm{C}-103$ is the chief threat to tank structural integrity. In this section peak pressures computed for a number of cases are presented. Uncertainties in fire parameters are illustrated by comparing peak pressure for a best-estimate base case with peak pressures computed for a range of possible values of key fire parameters. Results of the analyses are used in the next report section to assess the likelihood that a solvent fire could cause tank structural failure.

6.1.6.1 Base Case Solvent Fire. Key parameters for the base case fire, discussed in Sections $6.1,6.2$ and 6.3 are summarized in Table 6.3. The pressure transient calculated for a solvent fire using base case parameters is pictured in Figure 6.1. Internal tank pressure peaks at 8.5 psig (58.6 Kpa) at 286 seconds after fire initiation. Peak pressure is predicted to occur at the time when the fire is terminated by oxygen extinguishment. 
WHC-SD-WM-CN-032, REV. 0

ref. WHC-SD-WM-SARR-001 REV O-A
SUPPLEMENT 1

Table 6.3. Key Parameters for Base Case Solvent Fire.

\begin{tabular}{|l|l|}
\hline \multicolumn{1}{|c|}{ Parameter } & \multicolumn{1}{|c|}{ Value } \\
\hline Initial inflamed circle diameter & $0.305 \mathrm{~m}(1 \mathrm{ft})$ \\
\hline Flame radial spread rate & $1 \mathrm{~cm} / \mathrm{s}$ \\
\hline Solvent pool area & $40.9 \mathrm{~m}^{2}\left(440 \mathrm{ft}^{2}\right)$ \\
\hline Leak path description & $\begin{array}{l}\text { Five small pipes plus salt well } \mathrm{riser} \\
\text { open at } 7.5\left(\mathrm{~b} / \mathrm{in}^{2} \text { (gauge) (51 kPa) }\right. \\
(\text { see Table } 6.1)\end{array}$ \\
\hline Emissivity product, $\epsilon_{\mathrm{u}} \times \epsilon_{\mathrm{s}}$ & 0.9 \\
\hline Oxygen extinguishment level & $0.13 \mathrm{~mole} \mathrm{fraction}$ \\
\hline Specific burning rate & $1.2 \mathrm{~kg} / \mathrm{min} \mathrm{m}^{2}$ \\
\hline Combustion enthalpy & $33 \mathrm{MJ} / \mathrm{kg}^{2}(14,140 \mathrm{Btu} / \mathrm{lb})$ \\
\hline Headspace air volume & $2,663 \mathrm{~m}^{3}\left(94,000 \mathrm{ft}^{3}\right)^{\prime}$ \\
\hline
\end{tabular}

"Calculated headspace aîr volume after purpout of supernatant liquids. 
WHC-SD-WM-CN-032, REV. 0

ref. WHC-SD-WM-SARR-001 REV O-A
SUPPLEMENT 1

Figure 6.1 Tank Pressurization Predicted for Base Case Solvent Fire.

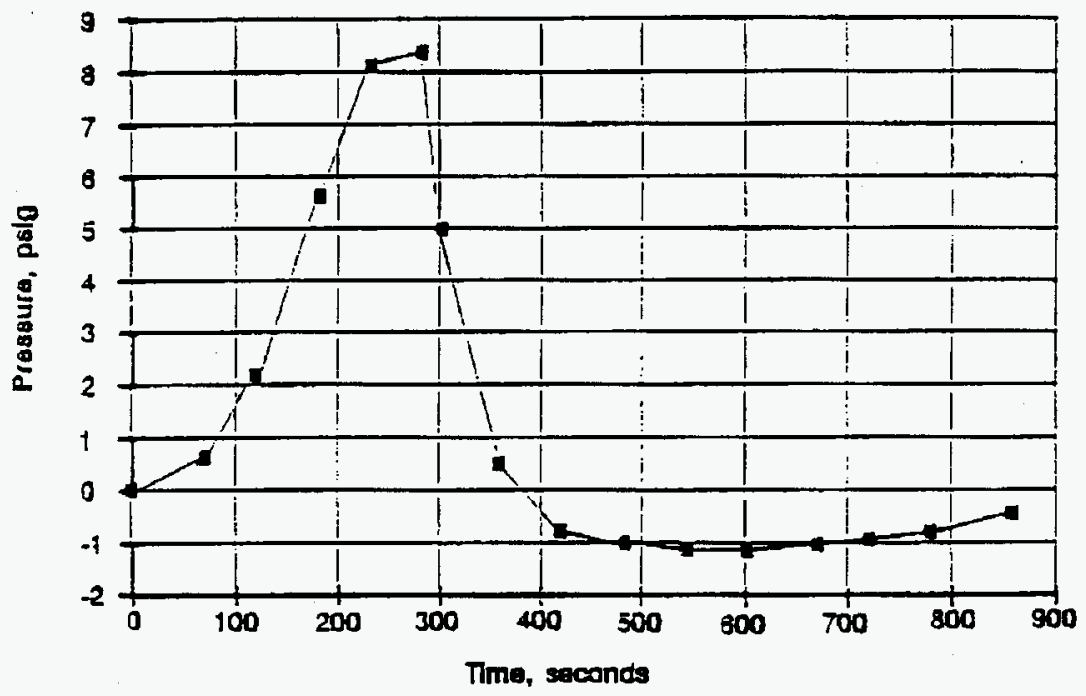




\section{WHC-SD-WM-CN-032, REV. 0 \\ ref. WHC-SD-WM-SARR-001 REV O-A}

After fire extinguishment, internal pressure falls rapidly as a result of gas venting and heat loss from the gas to tank surfaces. As indicated, tank gauge pressure is calculated to go negative at approximately 390 seconds, and reaches a minimum value of -1.2 psig (8.27 Kpa) at approximately 540 seconds. After this minimum, pressure gradually returns to ambient atmospheric pressure. The total volume of gas vented during the time when tank pressure exceeded atmospheric pressure was calculated to amount to $760 \mathrm{~m}^{3}$ or about $30 \%$ of the tank headspace volume.

6.1.6.2 Effect of Initial Inflamed Area. As noted in Table 6.3 the initial inflamed area was specified in the base case as a circle of $1 \mathrm{ft} .(0.31 \mathrm{~m})$ in diameter. The effect of initial inflamed area was evaluated by varying the circle diameter by a factor of 2 above and below the base value. The initial inflamed area for the two cases is thus a factor of 4 higher and lower than the area for the base case. Results of the analysis, expressed in terms of peak pressure, are presented in Table 6.4.

Table 6.4 Effect of Initial Inflamed Area on Peak Pressure

\begin{tabular}{|c|c|}
\hline $\begin{array}{c}\text { Diameter of Initial fire } \\
\mathrm{ft} .(\mathrm{m})\end{array}$ & $\begin{array}{c}\text { Peak Pressure psig (k } \\
\text { Pa) }\end{array}$ \\
\hline $0.5(0.15)$ & $8.5 \quad(58.6)$ \\
\hline $1.0 \quad(0.31)$ & $8.5 \quad(58.6)$ \\
\hline $2.0 \quad(0.62)$ & $8.5 \quad(88.3)$ \\
\hline
\end{tabular}

As indicated by the data of Table 6.3 peak pressure is not sensitive to initial inflamed area over the range studied. The calculated time to reach peak pressure was $294 \mathrm{sec}$ for the smaller area and $271 \mathrm{sec}$ for the 1 arger area. These differences in burn times reflect small differences in average burn areas for the two cases.

6.1.6.3 Effect of Flame Spread Rate. The base case spread $(1 \mathrm{~cm} / \mathrm{s})$ was selected as a realistic estimate for Tank $\mathrm{C}-103$ on the basis of available data discussed in Section 6.1.1. The effect of spread rate on peak pressure was quantified by running cases for spread rates of $0.1 \mathrm{~cm} / \mathrm{s}, 0.5 \mathrm{~cm} / \mathrm{s}$ and $2.0 \mathrm{~cm} / \mathrm{s}$. Results of the calculations are compared to results for the base case in Table 6.5.

Table 6.5 Effect of Flame Spread Velocity on Calculated Peak Pressure

\begin{tabular}{|c|c|}
\hline Fire Spread Velocity cm/s & Peak Pressure psig (k Pa) \\
\hline 0.1 & $1.8(12.4)$ \\
\hline 0.5 & $7.6(52.4)$ \\
\hline 1.0 & $8.5(58.6)$ \\
\hline 2.0 & $11.9(82.1)$ \\
\hline
\end{tabular}




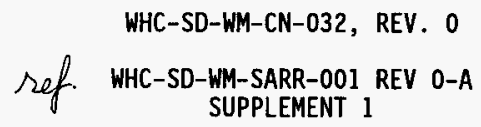

As indicated by the data of Table 6.5, peak pressures are calculated to vary significantly with fire propagation velocity. Time of fire extinguishment is calculated to $1214 \mathrm{~s}, 439 \mathrm{~s}$ and $180 \mathrm{~s}$ for spread rates of $0.1,0.5$ and $2.0 \mathrm{~cm} / \mathrm{s}$ respectively. The increase in peak pressure with spread velocity is the result of higher overall combustion rates due to the larger inflamed areas computed for higher spread rates.

6.1.6.4 Effect of Solvent Pool Area. The base case pool area, $440 \mathrm{ft}^{2}$ $\left(40.9 \mathrm{~m}^{2}\right)$, represents $10 \%$ of the cross-sectional area of the tank. This represents a first estimate of pool area following pumpout of supernatant liquid. The impact of pool area was quantified by varying pool area from $3.04 \mathrm{ft}^{2}$ (a circle $0.6 \mathrm{~m}$ in diameter) to the whole tank cross-sectional area. An additional case was run in which a spread velocity of $2 \mathrm{~cm} / \mathrm{s}$ was combined with the largest pool area. This case evaluates the effect of high spread velocity for the current waste configuration. The calculated variation of peak pressure with pool area is shown in Table 6.6.

As indicated by the data of Table 6.6 peak pressure increases with pool area up to an area of approximately $300 \mathrm{ft}^{2}\left(37.2 \mathrm{~m}^{2}\right)$. Larger pool areas do not result in higher peak pressures because overall combustion rate is limited by spread velocity and fire termination caused by oxygen reaching the extinguishment level. The calculated pool area at the time of fire extinguishment, for base case fire parameters, is $295 \mathrm{ft}^{2}\left(27.4 \mathrm{~m}^{2}\right)$; solvent areas larger than this would not become inflamed before fire extinguishment (spread velocity of $1 \mathrm{~cm} / \mathrm{s}$ ).

The smallest area considered, $3.04 \mathrm{ft}^{2}\left(0.28 \mathrm{~m}^{2}\right)$ corresponds to a pool size, below which, ignition probability may increase (see Section 5.0 of the main body of the report.) Pressure buildup for this case was based on the following parameters:

1. Gas emissivity was assigned a value of 0.34 , the value estimated for water vapor aline, and

2. venting was assumed to occur only by means of the cascade pipe to Tank $\mathrm{C}-102$.

These special "small-fire" parameters were employed to assure a conservative estimate of peak pressure. The lower value of gas emissivity used for this case (0.34) does not account for soot particles that would play a role for large fires. The neglect of other vent paths was based on the idea that a peak pressure in the neighborhood of $0.5 \mathrm{psig}(3.45 \mathrm{Kpa})$ is required to lift pit cover plates and open the u-tube seal on the HEPA vent pipe. This threshold may not be exceeded for small fires.

The high spread rate $(2 \mathrm{~cm} / \mathrm{s})$ case used pool area and gas volume parameters that apply to the current waste configuration. The peak pressure for this case is comparable to the value listed in Table 6.5 which is based on pool area and gas volume applicable to the post-pumped waste configuration. This similarity in calculated peak pressures for current and post-pumped waste configurations indicates that tank pressurization by postulated solvent fires 


\section{WHC-SD-WM-CN-032, REV. 0 ref. WHC-SD-WM-SARR-001 REV O-A
SUPPLEMENT 1}

would not be significantly affected by salt well pumping unless residual pools are smaller than about $10 \%$ of the tank cross-sectional area, the value assumed for the base case.

Table 6.6 Effect of Pool Area on Calculated Peak Pressure

\begin{tabular}{|c|c|c|c|}
\hline \multicolumn{2}{|c|}{$\begin{array}{l}\text { Pool Area } \\
f^{2}{ }^{2}\left(m^{2}\right)\end{array}$} & \multicolumn{2}{|c|}{$\begin{array}{l}\begin{array}{l}\text { Peak Pressure } \\
\text { psig (Kpa) }\end{array} \\
\end{array}$} \\
\hline 3.04 & $(0.28)$ & 0.47 & $(3.24)$ \\
\hline 50 & $(4.65)$ & 3.7 & $(25.5)$ \\
\hline 100 & $(9.29)$ & 6.4 & $(44.1)$ \\
\hline 200 & (18.59) & 8.1 & $(55.9)$ \\
\hline 440 & $(40.9)$ & 8.5 & $(58.6)$ \\
\hline 800 & $(74.4)$ & 8.5 & $(58.6)$ \\
\hline 4418 & (411) & 8.5 & $(58.6)$ \\
\hline 4418 & (411) & 11.9* & (82.1) \\
\hline
\end{tabular}

6.1.6.5 Effect of Leak Path Flow Resistance. As discussed in Section 6.1.3 known leak paths include five relatively small pipes and the larger salt well riser. The sensitivity of calculated peak pressure to leak path flow resistance was illustrated by analyzing a case in which the largest path, the salt well riser, was assumed to be unavailable. Peak pressure for this case is listed in Table 6.7.

Table 6.7 Effect of Leak Path Flow Resistance on Calculated Peak Pressure

\begin{tabular}{|c|c|c|}
\hline Leak Path Description & \multicolumn{2}{|c|}{$\begin{array}{c}\text { Peak Pressure } \\
\text { psig } \quad \text { (Kpa) }\end{array}$} \\
\hline $\begin{array}{c}5 \text { small pipes } \\
+ \\
\text { salt well riser* }\end{array}$ & 8.5 & (56.8 Kpa) \\
\hline 5 small pipes & 12.0 & $(82.7 \mathrm{kPa})$ \\
\hline
\end{tabular}

As indicated by pressures listed in Table 6.7, the opening of the salt well vent has a significant effect on limiting tank pressures. The smaller leak path size case 1isted in Table 6.7 is unrealistic because the salt well riser is ignored and because other uncharacterized leak paths (such as the HEPA filter vent line) are also ignored. 


\section{WHC-SD-WM-CN-032, REV. 0 \\ ref. WHC-SD-WM-SARR-001 REV O-A
SUPPLEMENT 1}

6.1.6.6 Effect of Gas Emissivity. As indicated in Equation (6.4), radiation heat transfer rate is proportional to the product $\epsilon_{\mathrm{g}} \cdot \epsilon_{\mathrm{s}}$. The base case ascribes a value of 0.9 to this product. Parametric runs were made by setting this product equal to 0.8 and 1.0 , and results are summarized in Table 6.8 .

Table 6.8 Effect of Emissivity on Calculated Peak Pressure

\begin{tabular}{|c|c|}
\hline Numerical Value of $\epsilon_{0} \cdot \epsilon_{\mathrm{s}}$ & $\begin{array}{c}\text { Peak Pressure psig } \\
(\mathrm{K} \mathrm{PQ})\end{array}$ \\
\hline 1.0 & $8.4(57.9)$ \\
\hline .9 & $8.5(58.6)$ \\
\hline 0.8 & $8.7(60.0)$ \\
\hline
\end{tabular}

As indicated by the data of Table 6.8, the value of the emissivity product, $\epsilon_{g} \cdot \epsilon_{s}$, has a relatively minor effect on peak pressure, over the range covered. Smaller values of emissivity product, which would cause calculated pressures to be larger, do not appear to be realistic.

\subsubsection{Effect of Heat Transfer Flux from Flame to Burning Solvent Surface.} Heat transfer from the flame to the burning liquid surface was evaluated to have a best-estimate value of $57 \mathrm{kw} / \mathrm{m}^{2}$ on the basis of handbook values discussed in Section 6.1.2. The sensitivity of predicted peak pressure to flame-pool surface heat transfer flux was illustrated by assigning this parameter values of $24.5 \mathrm{kw} / \mathrm{m}^{2}$ and $72 \mathrm{kw} / \mathrm{m}^{2}$. These values are handbook values for kerosene and rubber gloves respectively (Ayer et a1. 1989). Results of this calculation are displayed in Table 6.9.

Table 6.9 Effect of Flame-Pool Heat Transfer Rate on Predicted Peak Pressure

\begin{tabular}{|c|c|}
\hline $\begin{array}{c}\text { Flame-Pool Heat } \\
\text { Transfer Flux, kw/m² }\end{array}$ & $\begin{array}{c}\text { Peak Pressure } \\
\text { Psig (kPa) }\end{array}$ \\
\hline 24.5 & $8.5 \quad(58.6)$ \\
\hline 57 & $8.5 \quad(58.6)$ \\
\hline 72 & $8.4 \quad(57.9)$ \\
\hline
\end{tabular}

As indicated in Table 6.9, calculated peak pressures are insensitive to the flame-pool heat transfer flux over the range studied. This insensitivity is as expected because the flame-pool heat transfer rate is small compared to the rate of heat generation by combustion. The base case flame-pool heat transfer flux $\left(57 \mathrm{kw} / \mathrm{m}^{2}\right)$ amounts to only $8.5 \%$ of the combustion energy flux, so changes in this parameter have a relatively small effect on the rate of energy transfer to headspace air. 


\section{WHC-SD-WM-CN-032, REV. 0 \\ ref. WHC-SD-WM-SARR-001 REV O-A}

6.1.6.8 Effect of 0xygen Extinguishment Leve1. The oxygen extinguishment level determines the maximum quantity of fuel that can be oxidized in the fire. The base case value of 0.13 mole fraction was selected on the basis of large scale tests (see Section 4.4). The impact of oxygen extinguishment level was evaluated by making parametric runs at 0.11 and 0.175 mole fractions the range reported in solvent fire tests. Results are listed in Table 6.10.

As indicated in Table 6.10, calculated peak pressure is lower for the case where early extinguishment is assumed $\left(\mathrm{O}_{2}\right.$ extinguishment level of 0.175 mole fraction). Peak pressure does not increase significantly when the fire is assumed to continue until an oxygen mole fraction of 0.11 is reached. Although peak gas temperature was calculated to increase significantly when $0_{2}$ extinguishment mole fraction was parametrically reduced from 0.13 to 0.11 , the rate of gas outflow offset the increasing gas temperature, with the result that peak pressure did not increase significantly.

Table 6.10 Effect of 0xygen Extinguishment Levels on Calculated Peak Pressure

\begin{tabular}{|c|c|}
\hline $\begin{array}{c}\text { Oxygen Extinguishment Mole } \\
\text { Fraction }\end{array}$ & $\begin{array}{c}\text { Peak Pressure psig (k } \\
\text { Pa) }\end{array}$ \\
\hline 0.11 & $8.5(58.6)$ \\
\hline 0.13 & $8.5(58.6)$ \\
\hline 0.175 & $6.5(44.8)$ \\
\hline
\end{tabular}

Predicted integral gas volume vented from the tank was a maximum for the $\mathrm{O}_{2}$ extinguishment mole fraction of 0.11 as compared to all other cases analyzed. For this case, $19 \%$ of combustion gases $\left(\mathrm{CO}_{2}\right.$ and $\left.\mathrm{H}_{2} \mathrm{O}\right)$ were carried from the tank with vented air. This case also resulted in the maximum negative pressure developing in the tank during the cool down that follows fire extinguishment. The maximum in negative gage pressure for this case was calculated to be $1.6 \mathrm{psig}$.

6.1.6.9 Effect of Organic Liquid Burning Rate. The burning rate per unit area of pool surface is a factor in determining the combustion energy per unit of inflamed surface per unit time. The base case value of $1.2 \mathrm{~kg} / \mathrm{m}^{2}$ min was selected as a realistic estimate on the basis of experiments (see Section 4.3) taking into account the conditions that apply to Tank $\mathrm{C}-103$. Parametric runs were made for burning rates of 1.0 and $1.7 \mathrm{~kg} / \mathrm{m}^{2} \mathrm{~min}$. to $i 11$ ustrate the importance of this parameter, and results are presented in Table 6.11.

The pressures 1 isted in Table 6.11 increase with burning rate. The increase in pressure is small, indicating that uncertainties in burning rate do not result in large uncertainties in calculated peak pressures. 
WHC-SD-WM-CN-032, REV. 0 ref. WHC-SD-WM-SARR-001 REV O-A
SUPPLEMENT 1

Table 6.11 Effect of Specific Burning Rate on Calculated Peak Pressure

\begin{tabular}{|c|c|}
\hline $\begin{array}{c}\text { Specific Burning Rate } \mathrm{kg} / \mathrm{m}^{2} \\
\min \end{array}$ & Calculated Peak Pressure psig (k \\
\hline 1.0 & $8.4(57.9)$ \\
\hline 1.2 & $8.5(58.6)$ \\
\hline 1.7 & $9.3(64.1)$ \\
\hline
\end{tabular}

6.1.6.10 Effect of Combustion Energy of Organic Liquid. As noted in Section 6.1.1, the combustion enthalpy for the base case was assigned a value of $80 \%$ of the theoretical value for complete combustion. Parametric runs were made for combustion energies of $91 \%$ and $70 \%$ of the theoretical value and results are shown in Table 6.12.

Table 6.12 Effect of Combustion Energy on Calculated Peak Pressure

\begin{tabular}{|c|c|}
\hline $\begin{array}{c}\text { Combustion Energy BTU/lb } \\
(\mathrm{MJ} / \mathrm{kg})\end{array}$ & $\begin{array}{c}\text { Calculate Peak Pressure psig (K } \\
\text { Pa) }\end{array}$ \\
\hline $12370(28.9)$ & $8.2(56.5)$ \\
\hline $14140(33.0)$ & $8.5(58.6)$ \\
\hline $16080(41.3)$ & $8.7(60.0)$ \\
\hline
\end{tabular}

As indicated by the data of Table 6.12 , an increase in combustion energy is reflected in an increase in calculated peak pressure. The increase is relatively small, indicating that uncertainty in combustion efficiency will not significantly affect computed peak pressures.

\subsubsection{Conclusions from Thermal Hydraulic Analysis}

Findings from the thermal hydraulic analysis of postulated solvent fires in Tank $\mathrm{C}-103$ can be summarized as follows.

1. The peak pressure predicted for a postulated fire, using bestestimate fire parameters, is 8.5 psig $(58.6 \mathrm{kPa})$.

2. Fire spread rate was shown to be a parameter that had a significant impact on calculated peak pressure. Peak pressure was predicted to increase from $8.5 \mathrm{psig}(58.6 \mathrm{ka})$ to $11.9 \mathrm{psig}(82.1 \mathrm{kPa})$ when a conservative spread velocity of $2 \mathrm{~cm} / \mathrm{s}$, double the best estimate value, was assumed to apply. 


\section{WHC-SD-WM-CN-032, REV. 0 \\ refo WHC-SD-WM-SARR-001 REV O-A
SUPPLEMENT 1}

3. Partial removal of 1 iquid from Tank $C-103$ could reduce the area of solvent pools and/or cause solvent immobilization in sludge.

Solvent liquid pools smaller than approximately $300 \mathrm{ft}^{2}\left(27.9 \mathrm{~m}^{2}\right)$ are calculated to result in lower peak pressures than larger pools; therefore salt well pumping would lower predicted pool fire pressures or have little effect, depending on the size of pool/puddles left behind. Fire spread rates over immobile fuel surfaces, such as solvent permeated sludge, are much slower than for liquids. Therefore, calculated peak pressures are lower for immobilized solvent than for liquid pools.

4. A maximum of $19 \%$ of combustion products was predicted to be vented from the tank as a result of a pool fire. This percentage can be used to estimate aerosol release from the tank, if other depletion mechanisms are neglected.

5. Cool down of headspace air following fire extinguishment is predicted to cause negative pressures within the tank of approximately 1.2 psig (11.7 kPa).

6. Approximately $60 \mathrm{~kg}$ of solvent is consumed in a solvent fire that is extinguished at an oxygen mole fraction of 0.13 .

\subsection{COMPARISON OF PREDICTED PRESSURES WITH TANK STRUCTURAL LIMITS}

In this section predicted peak pressures are compared to internal pressure loading limits for the tank. The objective is to identify pool fire cases, if any, which would be likely to cause structural failure of the tank.

\subsubsection{Tank Structural Limits}

Structural analyses performed on single-shell waste tanks have identified tank response to various levels of internal pressure loadings (Julyk 1994). Key results for half-million-gallon tanks (which includes Tank $\mathrm{C}-103$ design) are summarized as follows.

1. The internal pressure Timit is $14 \mathrm{psig}(96.5 \mathrm{kPa})$. For higher pressure loadings, the dome deflection versus pressure curve experiences a sudden change in slope and splitting bond failure of the rebar is predicted for an additional small pressure increase.

2. If the tank were pressurized to $14 \mathrm{psig}(96.5 \mathrm{kPa})$ and then sudden $7 \mathrm{y}$ depressurized, the dome could collapse because of soil overburden loads (impact + deadweight). However, sudden depressurization of the tank was not explicitly addressed in Julyk (1994).

Pressure buildup in analyzed pool fires is relatively slow, occurring over a time period of minutes, likewise, the depressurization period is also relatively slow, occurring over a time period of minutes. On this basis dynamic loads are not expected to add significantly to static loads, and the 


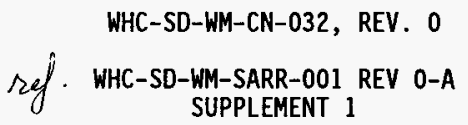

static analysis detailed by Julyk (1994) is expected to apply to pressure transients caused by analyzed solvent fires.

Cooldown of headspace air is calculated to result in negative gauge pressures in the tank during the cooldown transient. The response of the tank to vacuum loadings was not analyzed by Julyk (1994).

Based on these findings from the structural analysis reported by Julyk (1994), the following assumptions have been formulated for application to pool fire consequences.

1. For computed peak pressures of 14 psig or less, the tank will not suffer significant structural degradation and the dome will remain intact during depressurization and cooldown.

2. For computed peak pressures greater than 14 psig $(96.5 \mathrm{kPa})$, structural degradation of the dome is likely, and dome collapse is possible.

\subsubsection{Projected Solvent Fire Conditions for Tank Structural Failure}

The peak pressure predicted for a postulated fire, using best-estimate fire parameters, is $8.5 \mathrm{psig}(58.6 \mathrm{kPa})$. The maximum calculated peak pressure is $11.9 \mathrm{psig}(82.1 \mathrm{kPa})$ and corresponds to the case in which a fire spread rate of $2 \mathrm{~cm} / \mathrm{s}$, twice the best estimate value, was assumed (see Section 6.1). This peak pressure is below the assumed failure threshold (Julyk 1995) and on this basis overpressure failure is not predicted as an outcome of a solvent fire.

Tank structured temperatures remain low for the tank fire due to the short duration. Concrete surface temperatures remain below $90^{\circ} \mathrm{C}\left(1946^{\circ} \mathrm{F}\right)$. These temperatures are a skin effect and extend only a short distance into the walls. Temperatures $1 \mathrm{~cm}\left(0.5\right.$ in.) into the tank walls remain below $50{ }^{\circ} \mathrm{C}$ $\left(122{ }^{\circ} \mathrm{F}\right)$. Temperature effects, therefore, are not significant in terms of structural response.

Depressurization and cooldown of headspace air is predicted to cause negative gauge pressures in the tank of approximately $1.2 \mathrm{psig}(8.27 \mathrm{kPa})$. Negative pressures of this magnitude are roughly equivalent to a soil cover of $1.5 \mathrm{ft} .(0.46 \mathrm{~m})$ in terms of dome loading. Based on the currently measured soil depth on tank C-103 of approximately $5.3 \mathrm{ft}(1.6 \mathrm{~m})$ (Pianka 1995) and the analyzed limit of $10 \mathrm{ft}(3.0 \mathrm{~m})$ of soil (Ramble 1983), adequate margin is available to withstand the negative gauge pressure developed during the cooldown transient, and tank failure is not predicted (Julyk 1995). 
WHC-SD-WM-CN-032, REV. 0

ref. WHC-SD-WM-SARR-DOI REV O-A
SUPPLEMENT 1

\subsubsection{Conclusions Regarding Tank Response to Solvent Fires}

The following conclusions are drawn from a comparison of predicted fire pressure transients with tank structural limits.

1. For fire parameters which lead to low internal tank pressures (small surface area, low spread rate or small quantities of solvent), overpressure failure can be ruled out. The fire would burn to extinguishment by depleting $\mathrm{O}_{2}$ or fuel.

2. For pools containing more than approximately $60 \mathrm{~kg}$ of solvent and having surface areas larger than approximately $300 \mathrm{ft}^{2}\left(27.9 \mathrm{~m}^{2}\right)$, fires would burn to oxygen extinguishment. Because analyzed peak pressures are all lower than the analyzed structural limit, tank collapse is not a predicted outcome of a solvent fire in Tank C-103.

\subsection{POTENTIAL. RADIOLOGICAL DOSE CONSEQUENCES}

In this section potential radiological consequences from waste dispersed into the atmosphere as a result of a pool fire are estimated. Three cases are analyzed:

- large pool fire

- small puddle fire

- large solvent/sludge fire

A dome collapse scenario is not analyzed here because dome collapse is not a predicted outcome for solvent fires in $\mathrm{C}-103$. Radiological consequences for a dome collapse scenario have been quantified in SAR-065 (WHC 1995).

\subsubsection{Atmospheric Source Terms}

In this section, the quantities of nuclides that could be released to the atmosphere as a result of these three fire cases are estimated.

6.3.1.1 Large Pool Fire. For this case a fire burns to extinguishment in less than $300 \mathrm{~s}$ and in doing so oxidizes $60 \mathrm{~kg}$ or less of solvent. The preand post-pumped waste configurations would lead to significantly different fire sizes only if residual solvent pools after pumping contained less than $60 \mathrm{~kg}$ or had surface areas smaller than $300 \mathrm{ft}^{2}\left(28 \mathrm{~m}^{2}\right)$. The atmospheric source term computed herein is based on the assumption that residual solvent pools are equal to or larger than the limits cited in the foregoing sentence, and therefore that salt well pumping does not significantly affect the quantity of solvent burned.

Solvent Fire Smoke. The airborne release of radionuclide simulants under pool fire conditions has been measured in experiments in several countries and results have been reviewed by Mishima (1994). For indoors, vigorous burning 


\section{WHC-SD-WM-CN-032, REV. 0 \\ ref. WHC-SD-WM-SARR-001 REV O-A
SUPPLEMENT 1}

of large pools, Mishima (1994) recommends a bounding release fraction of 0.03 . All of the released material is assumed to be present in the form of respirable aerosols.

Higher release fractions may apply to fires that burn to dryness or where vigorous boiling of underlying aqueous solutions occurs. For such cases bounding release fractions of 0.1 to 0.2 could apply (Mishima 1994). These higher release fractions are not expected to apply to the case analyzed here because only a fraction of the organic will be combusted up to the time of oxygen extinguishment, and the duration of the fire is too short to allow vigorous boiling of underlying aqueous liquid. The atmospheric source term (of respirable particles) for a specific nuclide may be computed as follows.

$$
S=M \times C \times \text { ARF } \times \text { RF } \times \text { LPF }
$$

where

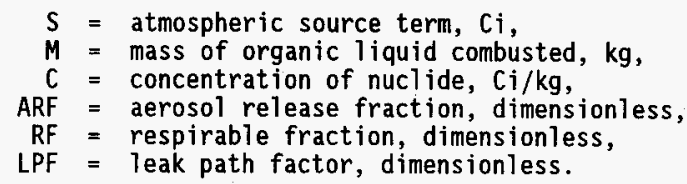

For the present case, ARF is assigned a value of 0.03 and RF is taken as unity, on the basis of bounding values presented by Mishima (1994). The leak path retention factor, LPF, was estimated at 0.2 on the basis of fractional leakage of combustion products from the tank headspace during the heating cycle caused by the postulated fire. The LPF value of 0.2 was the highest value computed in parametric calculations discussed in Section 6.1.5. The loss of aerosol particles by various depletion mechanisms was neglected.

The concentration of radionuclides in the organic liquid has been measured by Pool and Bean (1994) and results are summarized in Table 6.13. Also shown in Table 6.13 is the atmospheric source term. The values shown are based on Equation (6-12) taking $M=60 \mathrm{~kg}, A R F=0.03, R F=1$, and $L P F=0.2$.

Table 6.13 Atmospheric Source Term for Solvent Fire Aerosol

\begin{tabular}{||c|c|c|}
\hline Nuclide & Concentration m ci/kg & Atmospheric Source Term, m Ci \\
\hline Co -60 & $7.45(-4)$ & $2.7(-4)$ \\
\hline Sr -90 & $5.46(-1)$ & $2.0(-1)$ \\
\hline Cs -137 & $4.13(-2)$ & $1.5(-2)$ \\
\hline Eu -154 & $3.17(-4)$ & $1.1(-4)$ \\
\hline Eu -155 & $3.15(-4)$ & $1.1(-4)$ \\
\hline Am -249 & $1.79(-4)$ & $6.4(-5)$ \\
\hline $\mathrm{Pu}-238$ & $9.02(-5)$ & $3.2(-5)$ \\
\hline $\mathrm{Pu}-239+240$ & $1.94(-4)$ & $7.0(-5)$ \\
\hline
\end{tabular}




\section{WHC-SD-WM-CN-032, REV. 0 \\ ref. WHC-SD-WM-SARR-001 REV O-A
SUPPLEMENT 1}

Release from Sludge/Aqueous Phase. The postulated solvent fire would cause the heatup of underlying aqueous liquid or wet sludge. The release of radionuclides caused by the heatup of sludge or aqueous liquid has been estimated on the basis of the following simplifying assumptions.

1. The material at risk is the quantity of liquid (supernate or interstitial liquid) that can be evaporated by heat transferred from burning solvent.

2. Aerosol release attributable to water evaporation is bounded by the bounding value cited by Mishima (1994) for boiling liquids, 2 E-3.

A bounding estimate of water mass evaporated can be made by assuming that the flame heat flux to the inflamed surface, $8.7 \%$ of combustion energy (see Section 6.1.2), is absorbed in converting water from liquid to vapor. The mass of water evaporated, based on the maximum fuel burn of $60 \mathrm{~kg}$, is

$$
\mathrm{H}_{2} \mathrm{O} \text { evap. }=\frac{33 \mathrm{MJ}}{\mathrm{kg}} \times 60 \mathrm{~kg} \times 0.087 \times \frac{1 \mathrm{~kg} \text { vapor }}{2.26 \mathrm{MJ}}=76.2 \mathrm{~kg}
$$

The atmospheric source term is evaluated using Equation (6-12) with $M=$ $76.2 \mathrm{~kg}, \mathrm{C}=$ concentration of nuclides in aqueous phase, $A R F=2 \mathrm{E}-3$, and $L P F=0.2$. Nuclide concentrations and atmospheric source terms are listed in Table 6.14 .

Table 6.14 Atmospheric Source Term for Sludge/Aqueous Heatup Caused by Solvent Fire

\begin{tabular}{|c|c|c|}
\hline Nuclide & $\begin{array}{c}\text { Concentration } \\
M \text { Ci/kg }\end{array}$ & $\begin{array}{c}\text { Atmospheric Source } \\
\text { Term, M Ci }\end{array}$ \\
\hline Co -60 & $6.41 \mathrm{E}-2$ & $1.95 \mathrm{E}-3$ \\
\hline$S r-90$ & 2.64 & $8.05 \mathrm{E}-2$ \\
\hline$T c-99$ & $4.73 \mathrm{E}-2$ & $1.44 \mathrm{E}-3$ \\
\hline Cs -137 & $5.73 \mathrm{E1}$ & 1.75 \\
\hline $\mathrm{Pu}-238$ & $1.01 \mathrm{E}-2^{\mathrm{b}}$ & $3.08 \mathrm{E}-4$ \\
\hline $\mathrm{Pu}-239 / 240$ & $2.18 \mathrm{E}-2$ & $6.65 \mathrm{E}-4$ \\
\hline Am -241 & $3.64 \mathrm{E}-4$ & $1.11 \mathrm{E}-5$ \\
\hline
\end{tabular}

Poot and Bean 1994

b estimated from measured values of $\mathrm{Pu}-239 / 240$ in aqueous and organic phases 


\section{WHC-SD-WM-CN-032, REV. 0 \\ ref. WHC-SD-WM-SARR-001 REV O-A
SUPPLENENT 1}

HEPA Filter Blowout. The HEPA vent filter would be ruptured by overpressure if the vent valve were in the open position. The radioactive source term for the rupture of a HEPA vent filter has been evaluated and a bounding source term is presented in SAR-065 (WHC 1995). The dose consequences for HEPA failure described in SAR-065 are $4.9 \times 10^{-4} \mathrm{SV}$ at the onsite receptor and $2.7 \times 10^{-7} \mathrm{~Sv}$ offsite.

6.3.1.2 Smal1 Puddle Fire. As discussed in Section 5.0 of the main body of this report, solvent puddles smaller than $0.6 \mathrm{~m}$ in diameter may have a higher ignition frequency than larger pools. Bounding estimates of source terms for small puddles were made on the basis of the following assumptions.

1. The pool area, $0.28 \mathrm{~m}^{2}$, is based on the largest puddle that is considered to be small,

2. The pool is assumed to contain enough solvent so that the quantity burned is limited only by fire extinguishment at an oxygen mole fraction of 0.13 .

Solvent Fire Smoke. The quantity of solvent burned is approximately 60 $\mathrm{kg}$ so the inventory at risk is the same as discussed in Section 6.3.1.1 for large pools. The aerosol release fraction for the small fire is assigned a value of 0.1 , on the basis that the relatively long duration of the fire (approximately $3 \mathrm{hr}$.) could cause boiling of underlying aqueous liquid. This value is cited by Mishima (1994) as bounding for "Indoors, Burning Solvent over Aqueous Phase" fires. The leak path retention factor, based on the retention of combustion products in the tank when inflow begins after fire initiation, is calculated (from the thermal hydraulics model described in Section 6.1) to be 0.033 . The source term for this case may be calculated as a faction of the source term for large pools:

$$
\text { puddle source term }=1 \text { arge pool source term } \times \frac{0.1}{0.03} \times \frac{0.033}{0.2}
$$

puddle source term $=0.55 \times$ large pool source term.

Release from Sludge/Aqueous Phase. Aerosol release attributable to heatup of underlying waste can be estimated by the method used for large pools (6.3.1.1). A bounding estimate of water evaporation can be made by assuming that the puddle is deep enough to contain enough solvent $(60 \mathrm{~kg})$ to burn to oxygen extinguishment. The sludge/Aqueous waste source term on this basis is the same as for the large pool case, which is detailed in Table 6.14.

HEPA Filter Blowout. The peak pressure for this case, $0.47 \mathrm{psig}(3.24$ $\mathrm{kPa}$ ) [see Table 6.6] is less than half the value cited by Mishima (1994) for filter rupture. Therefore no source term attributable to HEPA filter blowout is applicable for this case. 


\section{WHC-SD-WM-CN-032, REV. 0 \\ sef. WHC-SD-WM-SARR-001 REV O-A
SUPPLEMENT 1}

6.3.1.3 Solvent Embedded In sludge. The scenario postulated for this case involves a fire that spreads slowly across a large pool of 7 iquid submerged in an inert, porous solid. It is assumed that capillary forces replenish liquid evaporated at the air/solvent interface, so that burning continues at the rate applicable to large pools, $1.2 \mathrm{~kg} / \mathrm{m}^{2} \mathrm{~min}$, and that the spread rate is $0.1 \mathrm{~cm} / \mathrm{s}$ as discussed in sections 4.2 and 6.1.5. Based on these assumptions, the fire is predicted to continue for $1200 \mathrm{~s}$, and vent $11 \%$ of combustion products.

Solvent Fire Smoke. The quantity of solvent burned for this case is the same as postulated for the large and small pool cases, $60 \mathrm{~kg}$. An aerosol release fraction of 0.1 is assumed to apply. This bounding value for fires over an aqueous phase (Mishima 1994) is used because the fire duration is relatively long (20 min) resulting in sludge heatup with the attendant evaporation of water.

The atmospheric source term for this case may be computed as a multiple of the source term for the large pool fire (Table 6.13) on the basis of ratios of leak path factors and aerosol release fractions for the two cases:

$$
\frac{\text { Embedded Solvent Source }}{\text { Large Pool Source }}=\frac{0.1}{0.03} \times \frac{0.11}{0.20}=1.83
$$

Thus the solvent smoke source term for this case is calculated to be 1.83 times the value estimated for the large pool case.

Release From Sludge/Aqueous Phase. The aerosol release attributable to sludge heatup is assumed to be caused by water evaporation, so the source term listed in Table 6.14 is assumed to apply.

HEPA Filter Blowout. The peak pressure predicted for this case is 1.8 psig $(12.4 \mathrm{kPa})$ [Table 6.5 ] is marginally higher than pressure drops that cause filter rupture (Mishima 1994). Therefore the source term quantified in SAR-065 (WHC 1995) is assumed to apply for this case.

\subsubsection{Potential Radiological Dose Consequences}

Potential dose consequences for the two accident scenarios described in Section 6.3.1 were evaluated as follows.

1. Doses attributable to solvent fires were computed from source terms for each case, based on nuclide concentrations listed in Tables 6.13 and 6.14. Fifty year committed doses were computed using the GENII Code, Version 1.485 (Huang 1995). Both external exposure (infinite plume) and inhalation uptake were accounted for.

2. Doses attributable to HEPA filter blowout were taken from SAR-065 (WHC 1995). 


\section{WHC-SD-WM-CN-032, REV. 0 \\ ref. WHC-SD-WM-SARR-001 REV $0-A$
SUPPLEMENT 1}

Projected doses, for both an onsite $(100 \mathrm{~m})$ and offsite $(15 \mathrm{~km})$ individual are listed in Table 6.15. Doses for all cases fall below guidelines for anticipated events (WHC 1993).

Table 6.15 Projected Doses for Postulated Solvent Fires in Tank $\mathrm{C}-103$

\begin{tabular}{|c|c|c|c|c|c|c|}
\hline \multirow{3}{*}{ Source Term Component } & \multicolumn{6}{|c|}{$\begin{array}{c}\text { Dose for Cases Analyzed } \\
\text { (Rem) }\end{array}$} \\
\hline & \multicolumn{2}{|c|}{ Large Pool Fire } & \multicolumn{2}{|c|}{ Puddle Fire } & \multicolumn{2}{|c|}{$\begin{array}{c}\text { Entrained Solvent } \\
\text { Fire }\end{array}$} \\
\hline & Onsite & Offsite & Onsite & Offsite & Onsite & offsite \\
\hline Solvent Fire smoke & $1.2 \mathrm{E}-3$ & $5.6 E-7$ & $6.6 E-4$ & $3.1 \mathrm{E}-7$ & $2.2 \mathrm{E}-3$ & $1.0 \mathrm{E}-6$ \\
\hline Sludge/Aqueous Release & $4.1 E-3$ & $1.9 \mathrm{E}-6$ & $4.1 E-3$ & $1.9 E-6$ & $4.1 E-3$ & $1.9 E-6$ \\
\hline HEPA B L OWOUT & $4.9 \mathrm{E}-2$ & $2.7 \mathrm{E}-5$ & - & $\cdots$ & $4.9 \mathrm{E}-2$ & $2.7 \mathrm{E}-5$ \\
\hline Total & $5.4 \mathrm{E}-2$ & $3.0 \mathrm{E}-5$ & $4.8 \mathrm{E}-3$ & $2.2 \mathrm{E}-6$ & $5.5 E-2$ & $3.0 \mathrm{E}-5$ \\
\hline
\end{tabular}

\subsection{POTENTIAL TOXICOLOGICAL EXPOSURES}

The combustion of organic liquid would produce a smoke plume that contained noxious gases and aerosols. These noxious substances could pose an inhalation hazard to personnel in the path of the plume.

In addition to soot particles and gaseous products of incomplete burning of hydrocarbon fuels, the combustion of TBP would produce oxides of phosphorous. The toxicological consequences of solvent fires have been evaluated on the bas is of predicted concentrations of $\mathrm{P}_{2} \mathrm{O}_{5}, \mathrm{CO}$, and $\mathrm{NO}_{2}$.

\subsubsection{Phosphorous Pentoxide}

Phosphorous Pentoxide is produced by the reaction of TBP with oxygen:

$$
\mathrm{C}_{12} \mathrm{H}_{27} \mathrm{PO}_{4}+180_{2}=12 \mathrm{CO}_{2}+13.5 \mathrm{H}_{2} \mathrm{O}+0.5 \mathrm{P}_{2} \mathrm{O}_{5}
$$

Based on Equation (6-13) stoichiometry, the mass ratio of $P_{2} 0_{5}$ to TBP is 0.27 . For a solvent burn of $60 \mathrm{~kg}$, of which $16 \%$ by mass is TBP (see Section 4.4), the total mass of $\mathrm{P}_{2} \mathrm{O}_{5}$ formed is:

$$
\mathrm{P}_{2} \mathrm{O}_{5} \text { mass }=60 \mathrm{~kg} \times 0.16 \times 0.27=2.6 \mathrm{~kg}
$$


WHC-SD-WM-CN-032, REV. 0

rof. WHC-SD-WM-SARR-001 REV O-A
SUPPLEMENT 1

An average release rate from the tank may be computed as follows:

$$
R=M \times L P F / t p
$$

where

$$
\begin{aligned}
R & =\text { release rate to atm., } \mathrm{kg} / \mathrm{s}, \\
M & =\text { mass of pollutant formed, } \mathrm{kg}, \\
L P F & =\text { fraction of pollutant vented during fire transient, } \\
\text { tp } & =\text { time interval when tank pressure exceeds atmospheric pressure. }
\end{aligned}
$$

The three fire cases analyzed in Section 6.3 have the same value of $M$, but different values of LPF and tp. The highest release rate corresponds to the large pool fire case, for which $L P F=0.2$ and $t p=400 \mathrm{~s}$. For this case, the release rate of $\mathrm{P}_{2} \mathrm{O}_{5}$ is computed as:

$$
R=2.6 \mathrm{~kg} \times 0.2 / 400=1.3 \mathrm{E}-3 \mathrm{~kg} / \mathrm{s} .
$$

The time integral tp and LPF for the small puddle fire are predicted to be $10,000 \mathrm{~s}$ and 0.033 , yielding a release rate for the puddle fire of:

$$
R=2.6 \mathrm{~kg} \times 0.033 / 10,000=8.58 \mathrm{E}-6 \mathrm{~kg} / \mathrm{s} \text {. }
$$

Finally, for the solvent imbedded in sludge fire, at release fraction of 0.11 and a time duration of $1200 \mathrm{~s}$ applies, leading to a predicted release rate of:

$$
R=2.6 \mathrm{~kg} \times 0.11 / 1200=2.38 \mathrm{E}-4 \mathrm{~kg} / \mathrm{s} .
$$

Onsite and offsite concentrations of $\mathrm{P}_{2} \mathrm{O}_{5}$ for these three fire cases, calculated using atmospheric dispersion factors of $0.035 \mathrm{~s} / \mathrm{m}^{3}$ and $1.6 \mathrm{E}-5 \mathrm{~s} / \mathrm{m}^{3}$ respectively, are listed in Table 6.16 .

Table 6.16 Predicted Concentrations of Phosphorous Pentoxide in Solvent Fire Plumes

\begin{tabular}{|c|c|c|}
\hline \multirow{2}{*}{ Solvent Fire Case } & \multicolumn{2}{|c|}{ Predicted Plume Concentration } \\
& Onsite & Offsite \\
\cline { 2 - 3 } & 46 & $2.1 \mathrm{E}-2$ \\
\hline Large Pool Fire & 0.3 & $1.4 \mathrm{E}-4$ \\
\hline Puddle Fire & 8.3 & $3.8 \mathrm{E}-3$ \\
\hline Entrained Solvent Fire & 0.3 & \\
\hline
\end{tabular}




\section{WHC-SD-WM-CN-032, REV. 0 \\ ref. WHC-SD-WM-SARR-001 REV O-A
SUPPLEMENT 1}

These concentrations are compared to risk acceptance guidelines in Section 6.4.5

\subsubsection{Carbon Monoxide}

The mass of $\mathrm{CO}$ formed is estimated on the basis of an emission factor for highly inefficient combustion. The highest emission factor for $\mathrm{CO}$ cited in Pollution Control Technology (1973) is $0.0425 \mathrm{~kg} / \mathrm{kg}$ for open burning of municipal refuse. Using this emission factor, the mass of $\mathrm{CO}$ produced by a burn of $60 \mathrm{~kg}$ of solvent is:

$$
M=0.0425(60)=2.55 \mathrm{~kg}
$$

Concentrations of $\mathrm{CO}$ in the downwind plume may be calculated from Table 6.16 data for $\mathrm{P}_{2} \mathrm{O}_{5}$ by multiplying by the mass ratio of $\mathrm{CO}$ to $\mathrm{P}_{2} \mathrm{O}_{5}: 2.55 / 2.60=$ 0.98 . Since this ratio is approximately unity, the predicted carbon monoxide concentrations, on a mass basis, are nearly identical to the $\mathrm{P}_{2} \mathrm{O}_{5}$ concentrations listed in Table 6.16. These concentrations are compared to risk acceptance guidelines in Section 6.4.5.

\subsubsection{Nitrogen Dioxide}

The mass of $\mathrm{NO}_{2}$ formed was estimated on the basis of an emission factor for $\mathrm{NO}_{2}$ cited for open burning of municipal refuse (Pollution Control Technology, 1973). The emission factor cited, $5.5 \mathrm{E}-3 \mathrm{~kg} / \mathrm{kg}$, is significantly lower than is cited for $0 i 1$ burning power plants, and is used here because the inefficient combustion expected for solvent fires is not conducive to high $\mathrm{NO}_{2}$ yields. The mass of $\mathrm{NO}_{2}$ produced by a burn of $60 \mathrm{~kg}$ of solvent is:

$$
M=(5.5 E-3)(60)=0.33 \mathrm{~kg}
$$

Concentrations of $\mathrm{NO}_{2}$ in the downwind plume may be calculated from Table 6.16 data for $\mathrm{P}_{2} \mathrm{O}_{5}$ by multiplying by the mass ratio of $\mathrm{NO}_{2}$ to $\mathrm{P}_{2} \mathrm{O}_{5}$ : $0.33 / 2.6=$ 0.127 . Predicted $\mathrm{NO}_{2}$ concentrations are 1 isted in Table 6.17. These concentrations are compared to risk acceptance guidelines in Section 6.4.5. 


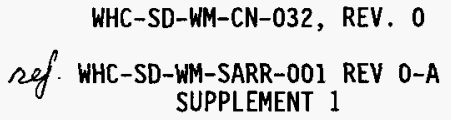

Table 6.17 Predicted Concentrations of $\mathrm{NO}_{2}$ in Solvent Fire Plume

\begin{tabular}{|c|c|c|}
\hline \multirow{2}{*}{ Solvent Fire Case } & \multicolumn{2}{|c|}{$\begin{array}{c}\text { Predicted Plume Concentration of } \mathrm{NO}_{2} \text {, } \\
\mathrm{mg} / \mathrm{m}^{3}\end{array}$} \\
\hline & Onsite & Offsite \\
\hline Large Pool Fire & 5.8 & $2.7 E-3$ \\
\hline Puddle Fire & $3.8 \mathrm{E}-2$ & $1.7 E-5$ \\
\hline Entrained Solvent Fire & 1.1 & $4.8 E-4$ \\
\hline
\end{tabular}

\subsubsection{Entrained Aqueous Waste}

The aqueous waste is caustic, and by itself would represent a toxicity hazard. The mass of waste postulated to become aerosolized by boiling (Section 6.3.1.1) is:

$$
76.2 \mathrm{~kg} \times 2 \mathrm{E}-3=0.15 \mathrm{~kg} \text {. }
$$

This quantity of liquid is small compared to the predicted mass of $P_{2} O_{5}$ (2.6 $\mathrm{kg}$ ), and therefore the airborne caustic material would be neutralized by airborne $\mathrm{P}_{2} \mathrm{O}_{5}$. Because the predicted airborne mass of aqueous waste is small compared to that of $\mathrm{P}_{2} \mathrm{O}_{5}$, the toxicity hazard posed is minimal by comparison and is neglected.

\subsubsection{Comparison to Risk Acceptance Criteria}

A method to determine if a release of toxic chemicals or gases meet risk acceptance criteria was developed for the tank farm safety analysis and is documented in SARR-065. The method is based on a document issued by an intercontractor committee (Craig 1993). Calculations for a mixture of gases are made by dividing the gas concentrations at a receptor by the appropriate limit and summing the result for each gas within a category with like health effects. The gases were divided into three categories: central nervous system toxics, systemic poisons, and corrosive and irritants. The emergency response planning guidelines (ERPGs) are used to evaluate the risk. The ERPGs are defined as follows:

The ERPG-1 value is the maximum airborne concentration to which it is believed that nearly all individuals could be exposed for up to 1 hour without experiencing other than mild transient adverse health effects or perceiving a clearly defined objectionable odor.

The ERPG-2 value is the maximum airborne concentration to which it is believed that nearly all individuals could be exposed for up to 1 hour without experiencing or developing irreversible or other serious health effects or symptoms that could impair their abilities to take protective action. 


$$
\begin{aligned}
& \text { WHC-SD-WM-CN-032, REV. } 0 \\
& \text { ref. WHC-SD-WM-SARR-001 REV O-A } \\
& \text { SUPPLEMENT } 1
\end{aligned}
$$

The ERPG-3 value is the maximum airborne concentration to which it is believed that nearly all individuals could be exposed for up to 1 hour without experiencing or developing.life-threatening health effects.

The PEL-TWA value is the employees' average airborne exposure in any 8-hour work shift of a 40-hour work week that shall not be exceeded.

The ERPG used for the evaluation depends on the receptor and the frequency class of the event. The risk acceptance criteria are shown in Table 6.18.

Table 6.18. Risk Acceptance Guidelines for Toxicological Health Effects.

\begin{tabular}{|c|c|c|}
\hline Event frequency & Onsite & offsite \\
\hline $10^{-2}$ to $10^{\circ}$ & $\leq$ ERPG-1 & $\leq$ PEL-TWA \\
\hline $10^{-4}$ to $10^{-2}$ & $\leq$ ERPG-2 & $\leq$ ERPG-1 \\
\hline $10^{-6}$ to $10^{-4}$ & $\leq$ ERPG-3 & $\leq$ ERPG-2 \\
\hline
\end{tabular}

*The smaller of the ERPG- 1 and the PEL-TWA value is used for the offsite limit.

The solvent fires are considered to be extremely unlikely events. The concentrations are therefore divided by the ERPG-2 for the offsite receptor risk acceptance evaluation, and ERPG-3 is used for onsite receptors.

The risk acceptance criteria are met if the sum of the concentrations of individual chemicals divided by the ERPG for the chemical is less than 1 for each category. The sum can be calculated as follows:

$$
S=\sum_{i=1}^{n} \quad \frac{C_{i}}{G_{i}}
$$

where

$$
\begin{aligned}
& C_{i}=\text { Concentration } \\
& G_{i}=\text { Risk guideline. }
\end{aligned}
$$

The ERPGs and categories for the pool fire gases are shown in Table 6.19 


\section{WHC-SD-WM-CN-032, REV. 0 \\ ref. WHC-SD-WM-SARR-001 REV O-A}

Table 6.19 ERPG for the pool fire gases.

$\begin{array}{llccc}\text { Gas } & \text { Category } & \text { ERPG-1 } & \text { ERPG-2 } & \text { ERPG-3 } \\ & & \mathrm{mg} / \mathrm{m}^{3} & 5 & \mathrm{mg} / \mathrm{m}^{3} \\ \mathrm{P}_{2} \mathrm{O}_{5} & \text { Corrosive and irritant } & 5 & 25 & \mathrm{mg} / \mathrm{m}^{3} \\ \mathrm{CO}^{2} & \text { systemic poison } & 230 & 690 & 100 \\ \mathrm{NO}_{2} & \text { Corrosive and irritant } & 3.8 & 47 & 1360 \\ & & & 94\end{array}$

The ERPGs for $\mathrm{P}_{2} \mathrm{O}_{5}$ and $\mathrm{NO}_{2}$ are taken from Hanford Information while the ERPG for CO was developed using the methodology described in Dentler 1995.

This report considers a large pool fire, a puddle fire and an entrained solvent fire. The peak concentrations occur for the large pool fire accident. The toxic consequences for the large pool fire will be evaluated as this event is limiting. The gas concentrations are taken from Table 6.16 and 6.17 .

$\mathrm{CO}$ is a systemic poison while the $\mathrm{P}_{2} \mathrm{O}_{5}$ and $\mathrm{NO}_{2}$ are both corrosives and irritants. The effects of $\mathrm{CO}$ is considered separately and the effects of $\mathrm{P}_{2} \mathrm{O}_{5}$ and $\mathrm{NO}_{2}$ are summed as follows:

\section{Onsite Receptor}

Systemic poisons:

CO concentration from section $6.4 .2=46 \mathrm{mg} / \mathrm{m}^{3}$

$\mathrm{ERPG}-3=1360 \mathrm{mg} / \mathrm{m}^{3}$

CO concentration over ERPG-3 $=0.034$

Corrosives and irritants:

$\mathrm{P}_{2} \mathrm{O}_{5}$ concentration from Table $6.16=46 \mathrm{mg} / \mathrm{m}^{3}$

ERPG-3 $=100 \mathrm{mg} / \mathrm{m} 3$

Concentration over ERPG-3 $=46 / 100=0.46$

$\mathrm{NO}_{2}$ concentration from Table $6.17=5.8 \mathrm{mg} / \mathrm{m}^{3}$

$E R P G-3=94 \mathrm{mg} / \mathrm{m}^{3}$

Concentration over ERPG-3 $=0.062$

Sum of fractions for corrosives and irritants $=0.46+0.06=0.52$

Offsite Receptor

Systemic poisons:

Co concentration from section $6.4 .2=0.021 \mathrm{mg} / \mathrm{m}^{3}$

ERPG-2 = $690 \mathrm{mg} / \mathrm{m}^{3}$

CO concentration over ERPG-2 $=0.021 / 690=3.0 \mathrm{E}-05$ 
WHC-SD-WM-CN-032, REV. 0

ref. WHC-SD-WM-SARR-001 REV O-A
SUPPLEMENT 1

Corrosives and irritants:

$P_{2} O_{5}$ concentration from Table $6.16=0.021 \mathrm{mg} / \mathrm{m}^{3}$

ERPG-2 $=25 \mathrm{mg} / \mathrm{m}^{3}$

$\mathrm{P}_{2} \mathrm{O}_{5}$ concentration over ERPG-2 $=0.021 / 25=8.4 \mathrm{E}-04$

$\mathrm{NO}_{3}$ concentration from Table $6.17=2.7 \mathrm{E}-03 \mathrm{mg} / \mathrm{m}^{3}$

$\mathrm{ERPG}-2=47 \mathrm{mg} / \mathrm{m}^{3}$

$\mathrm{NO}_{2}$ concentration over ERPG-2 $=5.7 \mathrm{E}-05$

Sum of fractions for corrosives and irritants $-5.7 \mathrm{E}-05+8.4 \mathrm{E}-04=9.0 \mathrm{E}-04$.

The pool fire will result in venting of headspace gases in addition to the release of combustion products. Release of head space gases is evaluated in SARR-065. The analysis approach used is the same as above but since a number of gases are involved, a spreadsheet is used to the sum the fractions. Gases selected and concentrations are based samples taken from the $\mathrm{C}-103$ headspace as reported in Mahlum 1994. The assumptions are:

Headspace volume $-2660 \mathrm{~m}^{3}\left(94,000 \mathrm{ft}^{3}\right)$

Release time - 400 seconds

Fraction of headspace gases released -0.30

Gas releases rate is assumed to be uniform

The gas release rate is $\left(2660 \mathrm{~m}^{3}\right)(0.30) / 400 \mathrm{~s}=2 \mathrm{~m}^{3} / \mathrm{s}$

Table 6.20 shows sum of fractions for $C-103$ headspace gas releases for a $2 \mathrm{~m}^{3} / \mathrm{s}$ release. This sum of fractions is added to the combustion products sum of fractions as shown in Table 6-21.

The accident may also result in a release of toxic materials that have been deposited on the HEPA filter since the accident can lead to a blowout of the filter. The release from a HEPA filter blowout was analyzed in SAR-065 and a sum of fractions of 0.042 for onsite and $2 E-06$ for offsite was calculated (assuming single shell tank solids source materials, passive ventilation, and an extremely unlikely accident). The effect of the filter blowout is included by conservatively adding these numbers to the sum of all three categories (central nervous system toxins, systemic poisons, and corrosives and irritants). The net results are shown in Table 6-21. 
Table 6-20. Toxic Exposure Due to Vented Headspace Gases.

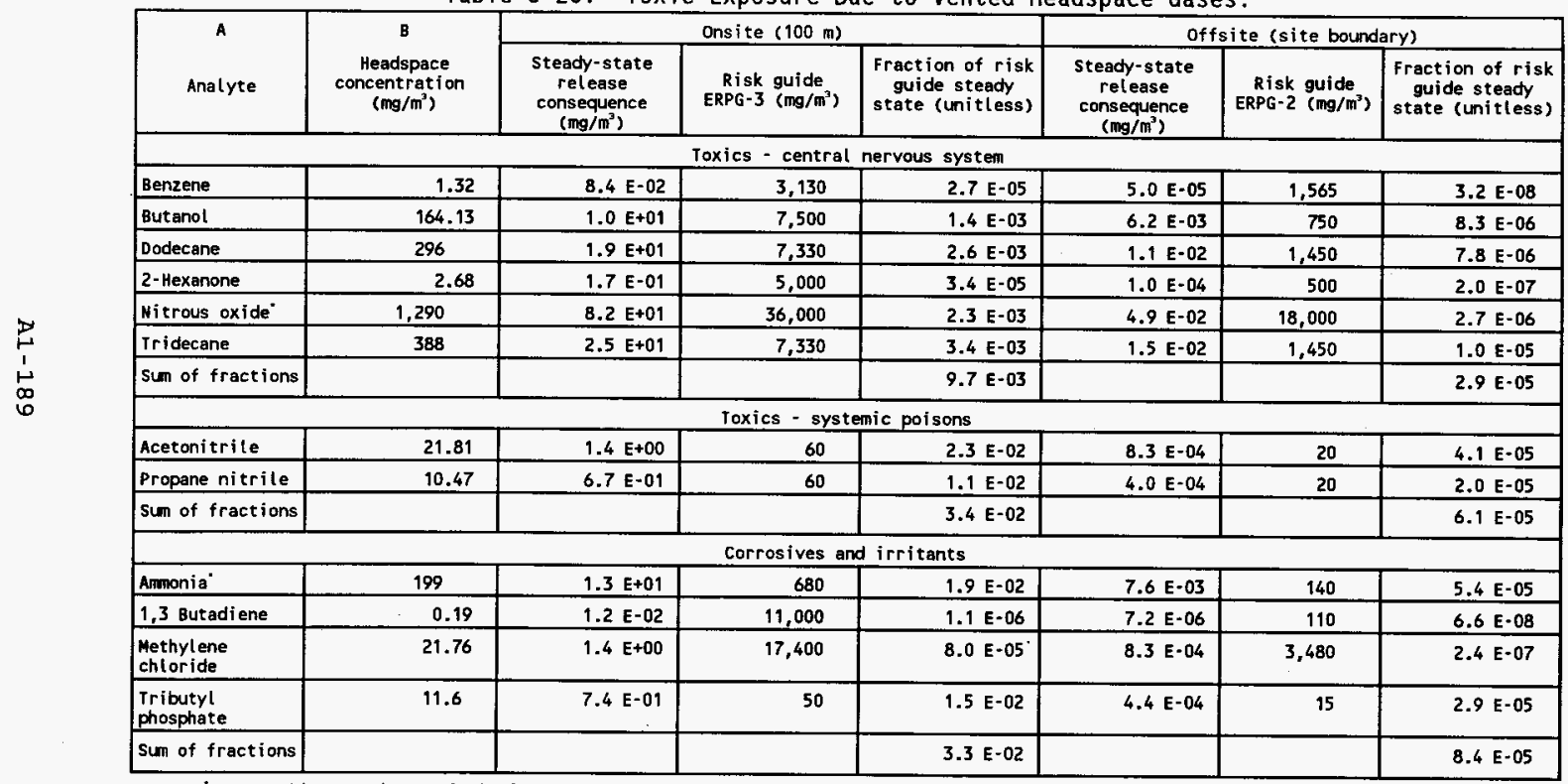

D. D. Mahlum et al., Ioxicologic Evaluation of Analytes from Tank 241-C-103, PNL-10189, Noventber 1994. 
WHC-SD-WM-CN-032, REV. 0

\section{ref. WHC-SD-WM-SARR-001 REV O-A
SUPPLEMENT 1}

Table 6.21. Toxic Risk Results (Sum of Fractions Evaluation).

\begin{tabular}{|c|c|c|c|}
\hline \multicolumn{4}{|c|}{ onsilte Evaluation } \\
\hline Toxic Source & $\begin{array}{c}\text { Central Nervous System } \\
\text { Toxins }\end{array}$ & Systemic Poisons & Corrosives \& Irritants \\
\hline $\begin{array}{l}\text { Combust ion Products } \\
\text { Headspace Gases } \\
\text { Filter Blowout }\end{array}$ & $\begin{array}{l}-\overline{-} \\
9.7 \mathrm{E}-03 \\
4.2 \mathrm{E}-02 \\
\end{array}$ & $\begin{array}{l}3.4 E-02 \\
3.4 E-02 \\
4.2 E-02 \\
\end{array}$ & $\begin{array}{l}5.2 E-01 \\
3.3 E-02 \\
4.2 E-02 \\
\end{array}$ \\
\hline Totals & $5.2 \mathrm{E}-02$ & $1.1 \mathrm{E}-01$ & $6.0 \mathrm{E}-01$ \\
\hline \multicolumn{4}{|c|}{ Offest te Evaluation } \\
\hline Toxic Source & $\begin{array}{c}\text { Central Nervous System } \\
\text { Toxins }\end{array}$ & Systenic Poisons & Corrosives Irritants \\
\hline $\begin{array}{l}\text { Combustion Products } \\
\text { Headspace Gases } \\
\text { Filter Blowout }\end{array}$ & $\begin{array}{l}2.9 E-05 \\
2.0 E-06 \\
\end{array}$ & $\begin{array}{l}3.0 E-05 \\
6.1 E-05 \\
2.0 E-06 \\
\end{array}$ & $\begin{array}{l}9.0 \mathrm{E}-04 \\
8.4 \mathrm{E}-05 \\
2.0 \mathrm{E}-06 \\
\end{array}$ \\
\hline Totals & 3.1E-05 & $9.3 E-05$ & $9.9 E-04$ \\
\hline
\end{tabular}

The corrosive and irritants produce the largest sum of fractions. The sum of fractions are less than 1 for both onsite and offsite calculations. The risk acceptance criteria are therefore met for this accident. 
WHC-SD-WM-CN-032, REV. 0

\section{sef. WHC-SD-WM-SARR-001 REV O-A
SUPPLEMENT 1}

\subsection{REFERENCES}

Akita, K., 1973, in Fourteenth Symposium. (International) on Combustion, The Combustion Institute, Pittsburgh, Pennsylvania, p. 1075.

Ayer, J. E., et al. 1988, Nuclear Fuel Cycle Facility Accident Analysis Handbook, NUREG-1320, Division of Industrial and Medical Nuclear Safety Office of Nuclear Material Safety and Safeguards, U.S. Nuclear Regulatory Commission, Washington, DC 20555.

Babrauskas, V., 1988, Burning Rates, SFPE Handbook of Fire Protection Engineering, First Edition, Section 2/Chapter 1, National Fire Protection Association, Quincy, Massachusetts.

Ballinger, M. Y. and P. C. OwCzarski, 1987, Aerosols Released in Accidents in Reprocessing Plants, Nuclear Technology, May 1988, Vol.81, pp. 278-292.

Brown, G. G., et al., 1950, "Unit Operations," John Wiley \& Sons, Inc., New York.

Burger, L. L., January 9, 1956, The Flammability of Vapors Above Purex Systems, HW-40820, Hanford Works, General Electric Company, Richland, Washington.

Craig, D. K. et al, 1993, Toxic Chemical Hazard Classification and Risk Acceptance Guidelines for Use in D.O.E. Facilities, WSRC-MS-92-206, Rev. 1., Westinghouse Savannah River Company, Aiken, South Carolina.

Dentler, M. L., 1995, "Toxicological Evaluation of Tank Waste Chemicals," HEHF Industrial Hygiene Assessments, Hanford Environmental Health Foundation, Richland Washington.

Edrington, R. S., 1991, BY and C Tank Farm Supernate Sample Analysis (Revision of 16220-PCL90-117), Internal Memo 28110-PCL91-048 to R.K. Tranbarger, Westinghouse Hanford Company, Richland, Washington, June 3, 1991.

Fox, G. L., et al.,1991, Tank 241-SY-101 Crust Burn Analysis, WHC-SD-WM-SAR-046 REV.0, Westinghouse Hanford Company, Richland, Washington

G7 assman, I., and F. L. Dryer, 1980,1981, Flame Spreading Across Liquid Fuels, Fire Safety Journal, 3 (1980/81) 123-138, El sevier Sequoia S.A., Lausanne - Printed in the Netherlands.

Hirano, T., et al., 1984, Flame Spread Over Crude 0il Sludge, Twentieth Symposium (International) on Combustion/The Combustion Institute, 1984/pp. 1611-1617. 
WHC-SD-WM-CN-032, REV. 0

ref. WHC-SD-WM-SARR-001 REV O-A
SUPPLEMENT 1

Huang, C. H., 1995, The Analysis of Dose Consequences for Solvent Pool Fire in Tank $6-103$, (internal memo $\mathrm{CHH}-8 \mathrm{M400-95-02}$ to J. K. Grigsby and

A. K. Postma, March 9, 1995), Westinghouse Hanford Company, Richland, Washington.

Huckaby, J. L., May 1994, Tank 241-C-103 Headspace Flammabi7ity, WHC-EP-0734 Rev. 1, Westinghouse Hanford Company, Richland, Washington.

Jordan, S., and W. Lindner, October 1983, The Behavior of Burning Kerosene, Aerosol Formation and Consequences, in Proceedings of the CSNI-Specialist Meeting on Interaction of Fire and Explosion with Ventilation Systems in Nuclear Facilities, LA-9911-C, Vol.I, Conference CSNI Report No. 83, Los Alamos, New Mexico, April 25-28, 1983.

Lapple, E. E, 1943, Trans. Am. Inst. Chem. Engrs., 39, 385 (June 1943).

Lee, H. A., August 1974, Final Report - Program for Fire Protection, Caves, Canyons, and Hot Cel7s, ARH-ST-104, At lantic Richfield Hanford Company, Richland, Washington.

Lewis, B. and G. Von Elbe, 1987, Combustion, Flames and Explosions of Gases, Third Edition, Academic Press, Inc. New York, New York.

Mahlum, D. D., J. Y. Young and R. E. Weller, Toxicological Evaluation of Analytes from Tank 241-C-103, PNL 10189, Pacific Northwest Laboratories, Richl and, Washington.

Malet, J. C., et a1., 1983, Solvent Poo7 Fire Testing, in Proceedings of the CSNI Specialist Heeting on Interaction of Fire and Explosion with Ventilation Systems in Nuclear Facilities, LA-9911-C, Vol.II, Conference CSNI Report No. 83, Los Alamos, New Mexico, April 25-28, 1983.

McAdams, W. H., 1954, "Heat Transmission," McGraw-Hi11, New York.

Mishima, J, 1994, Recommended Values and Technical Bases for Airborne Release Fractions, Airborne Release Rates and Respirable Fractions for Materials from Accidents in DOE Fuel Cycle, Ex-Reactor Facilities, Revision 2, DOE Handbook, U.S. Department of Energy, Washington, D.C. 20585.

NFPA, 1988, SFPE Handbook of Fire Protection Engineering, First Edition, National Fire Protection Association, Quincy, Massachusetts.

Perry, R. H., 1950, "Chemical Engineers' Handbook," McGraw-Hi11, New York.

Pianka, E. W., 1995, Soil Load Above Hanford Waste Storage Tanks, WHC-SD-WM-TI-665, Rev. 0, Westinghouse Hanford Company, Richland, Washington.

Pollution Control Technology, 1973, Research and Education Association, 342 Madison Avenue, New York, New York.

Pool, K. H. and R. M. Bean, 1994, PNL-9403, Waste Tank Safety Project: Analysis of Liquid Samples from Hanford Waste Tank 241-C-1-3, Pacific 


\section{WHC-SD-WM-CN-032, REV. 0 \\ sef. WHC-SD-WM-SARR-001 REV O-A
SUPPLEMENT 1}

Northwest Laboratory, Richland, Washington.

Postma, A. K., D. B. Bechtold, G. L. Borsheim, J. M. Grigsby, R. L. Guthrie, M. Kummerer, M. G. Plys, and D. A. Turner, 1994, Safety Ana7ysis of Exothermic Reaction Hazards Associated With the Organic Liquid Layer in Tank 241-C-103, WHC-SD-WM-SARR-001, Rev. 0, Westinghouse Hanford Company, Richland, Washington.

Quintiere, J. G., 1988, Surface Flame Spread, SFPE Handbook of Fire Protection Engineering, First Edition, Section 1/Chapter 24, National Fire

Protection Association, Quincy, Massachusetts.

Ramble, A. L., 1983, Single-Shell Waste Tank Load Sensitivity Study, SD-RE-TI-012, Rev. A-0, Rockwe11 Hanford Operations, Rich1 and, Washington.

Scott, K. V., 1995, Internal Memo, Subject: Comments on Projected Solvent Fire Conditions for Tank 241-C0193 Structural Failure, Letter Number 71430-KVS-95-003, March 1, 1995, Westinghouse Hanford Company, Rich1 and, Washington.

Siegel, R., and J. R. Howe11, 1989, Thermal Radiation Heat Transfer, Third Edition, Hemisphere Publishing Corporation, Washington DC.

Takeno, K., and T. Hirano, 1986, Flame Spread Over Porous Solids Soaked With a Combustible Liquid, Twenty-first Symposium (International) on

Combustion/The Combustion Institute, 1986/pp. 75-81.

Thorne, P. F., 1983, Principles of Fire and Explosion Protection, in Proceedings of the CSNI Specialist Meeting on Interaction of Fire and Explosion with Ventilation Systems in Nuclear Facilities, LA-9911-C, Vol. II, Conference CSNI Report No. 83, Los Alamos, New Mexico.

WHC, 1993, Nonreactor Facility Safety Analysis Manual, WHC-CM-4-46, Westinghouse Hanford Company, Richland, Washington.

WHC, 1995, SAR-065, Westinghouse Hanford Company, Richland, Washington.

Wood, B. D., 1971, Mass Fire Model: An Experimental Study of the Heat Transfer to Liquid Fuel Burning from a Sand-Filled Pan Burner, Combustion Science and Technology, Vol. 4, pp. 113-129.

Yamagauchi, T, and K. Wakasa, $0 i 7$ Pool Fire Experiment, in Fire Safety Science, Proceedings of the First International Symposium, Editors, C. E. Grant and P.J. Pagni, Hemisphere Publishing Corporation. 
WHC-SD-WM-CN-032, REV. 0

ref. WHC-SD-WM-SARR-001 REV O-A
SUPPLEMENT 1

This page intentionally left blank. 
WHC-SD-WM-CN-032, REV. 0

\section{ATTACHMENT A-2}

APPENDIX E OF WHC-SD-WM-SAR-046, REV. O-A

This attachment describes a comparison of the heat conduction algorithm used in Poolfire.3 with an exact solution. 
WHC-SD-WM-CN-032, REV. 0

This page intentionally left blank. 


$$
\begin{aligned}
& \text { WHC-SD-WM-CN-032, REV. O } \\
& \text { ref. WHC-SD-WM-SAR-046 } \\
& \text { REV. } 0
\end{aligned}
$$

\section{APPENDIX E}

\section{COMPARISON OF HEAT TRANSFER MODEL HITH KNOWN SOLUTIONS TO SPECIFIC PROBLEMS}

\section{B.1 COMPARISON OF MODEL PREDICTIONS WITH KNOWN EXACT SOLUTIONS FOR TRANSIENT CONDUCTION}

A number of checks were made to verify the correctness of the nodalized model for transient conduction described in Section 6.0. Among these was a hypothetical case for a semi-infinite slab initially at a temperature of 100 , with surface temperature of 0 imposed at time 0 . Carslaw and Jaeger 1959 give an exact analytical solution for this case as:

$$
T=T_{0} \operatorname{erf}\left[\frac{x}{2(\alpha T)^{1 / 2}}\right]
$$

where:

$$
\begin{aligned}
T & =\text { Temperature at time }(t) \\
T_{0} & =\text { Initial temperature in solid } \\
x & =\text { Distance measured from surface } \\
\alpha & =\text { Thermal diffusivity of solid } \\
t & =\text { Time from application of zero surface temperature } \\
T & =0 \text { at } x=0 \text { for } t>0 \\
\text { erf } & =\text { Error function }
\end{aligned}
$$

The exact solution, Equation (E-1), is compared with model predictions in Figure E-l. For this case heat generation was set equal to zero because the exact solution does not include it. Predictions are shown for $1,10,50$, and 200 time steps (1 s long). In general, the agreement is judged to be satisfactory. For small numbers of time steps, the model slightly underpredicts the temperature change. This is as expected because temperature changes are part of a time increment behind time in the explicit solution method used.

The good agreement exhibited in Figure $E-1$ is in part due to selection of the correct time step for the node thickness and thermal diffusivity. A time step for which heat just penetrates a node thickness is always used. 
WHC-SD-WM-CN-032, REV. O

sef. WHC-SD-WM-SAR-046
REV. 0

Figure E-1. Predicted Temperature Transient in Semi-Infinite S1ab.

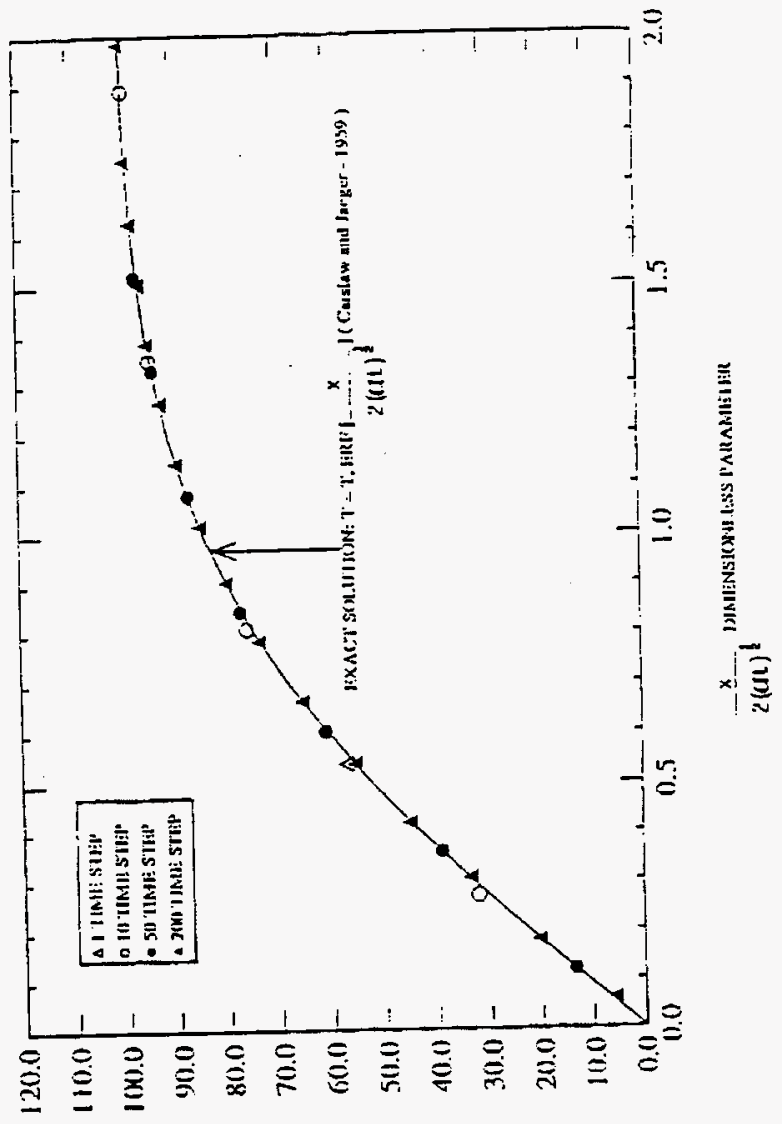




\section{WHC-SD-WM-CN-032, REV.O \\ ref. WHC-SD-WM-SAR-046
REV. 0}

\section{E.2 CHECKING OF MODEL WITH REgARDS TO INTERNAL HEAT GENERATION}

Two tests of the models' ability to correctly account for internal heat generation were made. First, the boundaries, the surface and the last node were made adiabatic and heat generation rate, $Q / \sigma C_{p}$, was set equal to unity. The model predicted a rise in temperature in all nodes of $1 / \mathrm{s}$, as expected, supporting the validity of the model.

A second independent test of the model involved temperature distributions in a slab in which the material generates internal heat. This problem is discussed by Lees 1989 , and we follow his derivation. The heat generated per unit volume per unit time is given by Lees 1989 in Arrhenius form:

$$
Q=Q^{\prime} \sigma A \exp \left[-\frac{E}{R T}\right]
$$

where:

$$
\begin{aligned}
& Q^{\prime}=\text { Heat generated per unit mass per unit time } \\
& \sigma=\text { Density of material } \\
& A=\text { Preexponential factor } \\
& E=\text { Activation energy } \\
& R=\text { Gas constant } \\
& T=\text { Absolute temperature }
\end{aligned}
$$

Lees 1989 derives a self-heating parameter, $\delta$, defined as follows:

$$
\delta=\frac{Q^{\prime} \sigma A}{k} r^{2} \frac{E}{\mathrm{RT}_{\mathrm{s}}{ }^{2}} \exp \left(-\frac{\mathrm{E}}{\mathrm{RT}_{\mathrm{s}}}\right)
$$

where:

$$
\begin{aligned}
r & =\text { Half-thickness of slab } \\
k & =\text { Thermal conductivity of slab } \\
T s & =\text { Temperature at surface of slab }
\end{aligned}
$$

Lees further shows that a critical value of $\delta$ is reached. For higher values of $\delta$, no steady state temperature solution exists, and self-heating 


WHC-SD-WM-CN-032, REV. D
ref. WHC-SD-WM-SAR-046
REV. 0

continues. For $\delta$ values smaller than the critical value heat is dissipated as fast as it is generated, and a steady-state temperature distribution is reached. The critical value of $\delta$ is:

$$
\delta_{c}=0.88
$$

In order to solve Equations $(E-3)$ and (E-4) for the critical half thickness ( $r$ when $\delta=0.88$ ), we assigned $Q / O C_{p}$ values based on linear interpolation for synthetic crust:

$$
\begin{aligned}
\mathrm{T} & <120{ }^{\circ} \mathrm{C}-\mathrm{Q} / \sigma \mathrm{C}_{\mathrm{p}}=\mathrm{O} \\
120{ }^{\circ} \mathrm{C} & <\mathrm{T}<220{ }^{\circ} \mathrm{C}-\mathrm{Q} / \sigma \mathrm{C}_{\mathrm{p}}=0.14\left(\mathrm{~T}{ }^{\circ} \mathrm{C}-120\right)-{ }^{\circ} \mathrm{C} / \text { minutes } \\
220{ }^{\circ} \mathrm{C} & <\mathrm{T}<250{ }^{\circ} \mathrm{C}-\mathrm{Q} / \sigma \mathrm{C}_{\mathrm{p}}=14+16.2\left(\mathrm{~T}{ }^{\circ} \mathrm{C}-220\right)-{ }^{\circ} \mathrm{C} / \text { minutes } \\
\mathrm{T} & <250{ }^{\circ} \mathrm{C}-\mathrm{Q} / \sigma \mathrm{C}_{\mathrm{p}}=500{ }^{\circ} \mathrm{C} / \text { minutes }
\end{aligned}
$$

For $Q / \sigma C$ values for the temperature range of $120^{\circ} \mathrm{C}$ to $220^{\circ} \mathrm{C}$, we computed a half-thickness of:

$$
r_{c}=0.028 \mathrm{ft}
$$

This result indicates that slabs thinner than $0.056 \mathrm{ft}$ should have steady state temperatures while thicker ones should continue to heat.

A test run was made with the model for a slab $0.0513 \mathrm{ft}$ in thickness. The initial temperature was approximately $130^{\circ} \mathrm{C}$, and the two surfaces were held at the initial temperature. Results are presented in Figure E-2. The key result shown by Figure E-2 is that a steady-state temperature profile develops after approximately $900 \mathrm{~s}$.

A repeat run was made with the slab twice as thick $(0.1025 \mathrm{ft})$ and the results are shown in Figure E-3. The key finding is that a steady state temperature does not exist. This is as expected from calculations based on the equations of lees 1989. Although these particular results do not apply to tank 10l-SY crust, the confirmation of the correct critical slab width lends credibility to the internal heat generation capability of the model. 
WHC-SD-WM-CN-032, REV. O

ref. WHC-SD-WM-SAR-046
REV. 0

Figure E-2. Model Predictions for a Slab $0.0513 \mathrm{ft}$ Thick.

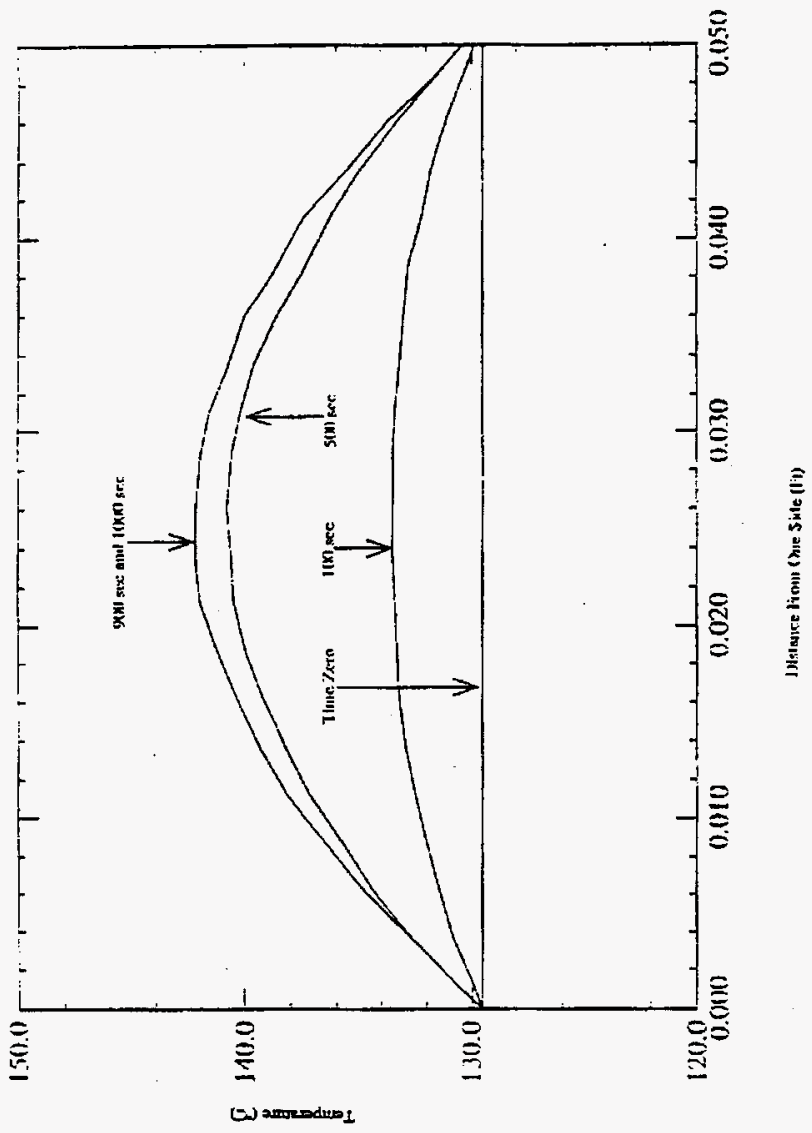


WHC-SD-WM-CN-032, REV: $O$

ref. WHC-SD-WM-SAR-046

Figure E-3. Mode1 Prediction for a Slab $0.1025 \mathrm{ft}$ Thick.

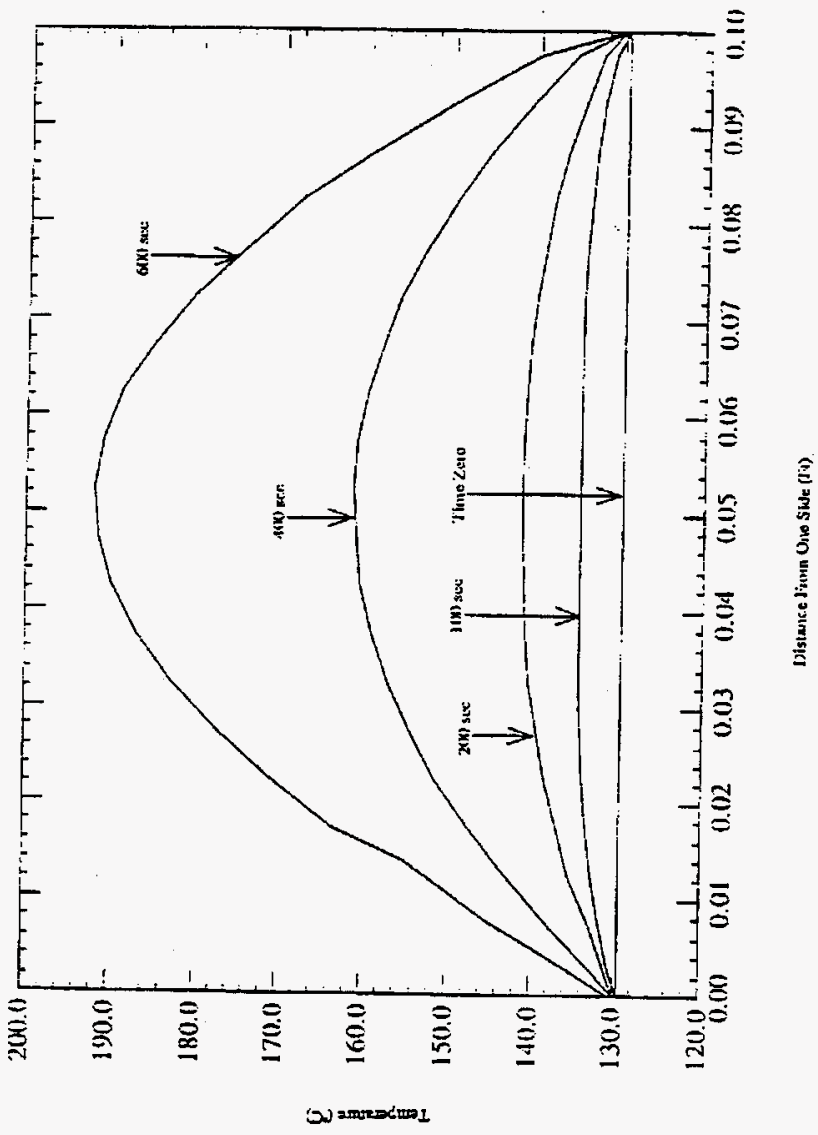




$$
\begin{aligned}
& \text { WHC-SD-WM-CN-033 REV. } 0 \\
& \text { sef. WHC-SD-WM-SAR-046 } \\
& \text { REV. } 0
\end{aligned}
$$

\section{E.3 REFERENCES}

Carslaw, H. S., and J. C. Jaeger, Conduction of Heat in Solids, Second Edition, Oxford at the Clarendon Press, London, 1959.

Lees, F. P., Loss Prevention in the Process Industries, Volume 1, Butterworths, London, 1989. 
WHC-SD-WM-CN-032, REV. $O$

ref. WHC-SD-WM-SAR-046
REV. 0

This page intentionally left blank. 


\section{WHC-SD-WM-CN-032, REV. O \\ sef. WHC-SD-WM-SAR-046
REV. 0}

\section{ATTACHMENT A-3}

\section{MEMO FROM M. EPSTEIN OF FAI TO A. K. POSTMA, "CONFIRMATION OF POSTMA'S SOLVENT-FIRE TANK-PRESSURE TRANSIENT MODEL," DATED SEPTEMBER 26, 1995.}

This attachment describes an entirely independent pressurization calculation for confined pool fires. This work was suggested by A. K. Postma and was performed at the request of D. A. Turner of Westinghouse Hanford.

Results confirm the substantial accuracy of the Poolfire. 3 program. 
WHC-SD-WM-CN-032, REV. $O$

ref. WHC-SD-WM-SAR-046

REV. 0

This page intentionally left blank. 


\section{通}

Fauske \& Associates, Inc.

DATE: September 26, 1995

T0: Arlin Postma

G \& $P$ Consulting

FAX: (503) 623-0479

FROM: Michael Epstein Fauske \& Associates, Inc.

SUBJECT: Confirmation of Postma's Solvent-Fire Tank-Pressure Transient Model

This memo reports a model for predicting the pressure history during a postulated solvent fire in Tank C-103. The model is essentially an independently constructed version of the model reported by Postma (1995) to predict Tank C-103 pressurization. The purpose of the present model is to provide an independent calculation to confirm Postma's predicted pool-fireinduced pressure transients.

We consider a circular pool of solvent whose cross-sectional area is small compared to the total surface area of sludge. Immediately following ignition at the center of the pool a flame of initial radius $r_{0}$ (measured from the center of the solvent pool) begins to spread as a cylindrically expanding surface. The flame stops spreading when it reaches a size $r_{p}$ which coincides with the radius of the solvent pool. The flame goes out when the bulk oxygen concentration $Y$ (mass fraction) in the tank headspace falls below the oxygen extinction concentration $Y_{\text {ext }}$. The flame may self-extinguish before it reaches the periphery of the pool. The heat generated by the flame causes the tank to pressurize. The increased pressure results in opening several flow paths (vents) from the tank headspace to the atmosphere. These vents act to reduce the pressure rise rate and the peak pressure compared to a sealed tank. After the fire goes out a cool down of headspace air occurs which produces a partial vacuum within the tank. Fresh air is then drawn into the tank and the

16 W070 West 83rd Street · Burr Ridge, Illinois 60521 $\cdot$ (708) 323-8750 Telefax (708) $986-5481$ 
pressure returns to atmospheric.

The approach to the calculation of the pressure-time history inside the tank headspace is based on the following set of simplifying assumptions.

(1) The physical properties of the mixture of air and combustion products are constant and taken to be those of air.

(2) The pressure $P$ is uniform throughout the tank headspace.

(3) The temperature and oxygen concentration within the tank headspace are uniform in space.

(4) The surface of the sludge and the inside surface of the tank remain at constant temperature $T_{w}$ during the pressure transient.

(5) Heat transfer from the soot-laden headspace gas to the surface of the sludge and the tank wall occurs via thermal radiation and turbulent natural convection.

(6) Flow through the vents is well-represented by incompressible flow theory.

(7) The ideal equation of state is applicable to the headspace gas.

(8) The burning rate of the solvent per unit area of inflamed pool surface $\dot{m}_{b}$ " is a known function of the size (diameter) of the inflamed area and the flame spreading velocity $v_{f}$ is a known constant.

The equations of conservation of energy, mass of headspace gas, and mass

16 W070 West 83rd Street - Burr Ridge, Illinois 60521 - (708) 323-8750 
WHC-SD-WM-CN-032, REV. 0

of oxygen within the headspace are

$$
\begin{aligned}
& \rho C_{v} V \frac{d T}{d t}=\dot{m}_{v} \Delta H-\dot{m}_{v} \frac{R}{M_{g}} T-\epsilon \sigma\left(T^{4}-T_{w}^{4}\right) A_{w} \\
&-0.13 k\left(T-T_{w}\right) A_{w}\left[\frac{g\left(T-T_{w}\right)}{\nu \alpha T_{w}}\right]^{1 / 3}-\dot{m}_{v} c_{p}\left(T_{w}-T\right) \\
& V \frac{d \rho}{d t}=-\dot{m}_{v}
\end{aligned}
$$

and

$$
\rho V \frac{d Y}{d t}=-r \dot{m}_{b}-\dot{m}_{v}\left(Y_{\infty}-Y\right)
$$

respectively. The nomenclature list at the end of this memo gives the meanings of the symbols as well as the numerical values of the fixed parameters. The last term in Eq. (1) and the last term in Eq. (3) appear only for the suction period when the headspace pressure falls below the outside atmosphere pressure $\left(P<P_{\infty}\right)$. Once $\rho$ and $T$ are determined from Eqs. (1) and (2) the tank pressure follows from the ideal gas law:

$$
\mathrm{P}=\rho \frac{\mathrm{R}}{\mathrm{M}_{\mathrm{g}}} \mathrm{T}
$$

The mass flow rate through the vents is

$$
\dot{m}_{v}=\left\{\begin{array}{cc}
A_{e f f}\left[2 \rho\left(P-P_{\infty}\right)\right]^{1 / 2} & \text { for discharge }\left(P \geq P_{\infty}\right) \\
-A_{e f f}\left[2 \rho_{\infty}\left(P_{\infty}-P\right)\right]^{1 / 2} & \text { for suction }\left(P<P_{\infty}\right)
\end{array}\right.
$$


where $A_{e f f}$ is an effective vent area that appropriately accounts for all the actual vent areas and the frictional resistance associated with each vent. Since each vent path $i$ may be represented as an equivalent circular pipe of length $L_{i}$ diameter $D_{i}$ and friction factor $f_{i}$ (Postma, 1995), the expression for $A_{\text {eff }}$ is

$$
A_{\text {gff }}=\frac{\pi}{8} \sum_{i} D_{i}^{2}\left(\frac{D}{L f}\right)_{i}
$$

From the physical description of the vent paths and the tank pressures at which they become available (Postma, 1995), we estimate that

$$
A_{\theta f f}=\left\{\begin{array}{lll}
4.5 \times 10^{-3} \mathrm{~m}^{2} & \text { for } & P \leq 0.151 \mathrm{MPa} \\
1.86 \times 10^{-2} \mathrm{~m}^{2} & \text { for } & P>0.151 \mathrm{MPa}
\end{array}\right.
$$

The burning rate of the solvent is simply the known specific burning rate $\dot{m}_{b} "$ multiplied by the instantaneous cross sectional area $\pi R_{f}^{2}$ of the fire, where $R_{f}$ is the radius of the flame. Thus

$$
\dot{\mathrm{m}}_{\mathrm{b}}=\pi \mathrm{R}_{\mathrm{f}}^{2} \dot{\mathrm{m}}_{\mathrm{b}}^{\prime \prime}
$$

where

$$
\begin{aligned}
& R_{f}=R_{f, 0}+v_{f} t \\
& \dot{m}_{b}^{\prime \prime}=\dot{m}_{f, \infty}^{\prime}\left[1-\exp \left(-7.0 R_{f}\right)\right]
\end{aligned}
$$

Note that $\dot{m}_{b}$ is set equal to zero once $Y$ falls below $Y_{\text {ext }}$ and $R_{f}$ is not allowed to exceed $R_{p}$. Equation (11) reflects a measured reduction in the specific burning rate when the inflamed area is small (Babranskas, 1988; see Postma, 1955). 
The initial conditions for Eqs. (1) to (3) are

$$
T=T_{w}, \rho=\frac{M_{g} P_{\infty}}{R T_{w}}, Y=Y_{\infty} \text { at } t=0
$$

The equations were integrated using the simple Euler forward integration method. The parameters for the base case solvent fire are the same as those recommended by Postma; namely,

$$
\begin{aligned}
& R_{f, 0}=0.3 \mathrm{~m} \\
& v_{f}=0.01 \mathrm{~m} \mathrm{~s}^{-1} \\
& R_{p}=3.6 \mathrm{~m} \\
& \epsilon=0.9 \\
& \mathrm{Y}_{\text {ext }}=0.142 \\
& \dot{\mathrm{m}}_{\mathrm{b}, \infty}=2 \times 10^{-2} \mathrm{~kg} \mathrm{~m}^{-2} \mathrm{~s}^{-1} \\
& \Delta H=3.3 \times 10^{7} \mathrm{~J} \mathrm{~kg}^{-1}
\end{aligned}
$$

The predicted best case tank-pressure history is shown in Fig. 1. The circles are Postma's predicted values. The agreement between the two calculations is good with the present result yielding a peak pressure of 0.159 MPa (8.7 psig), at $t=273 \mathrm{sec}$, versus Postma's peak pressure prediction of $0.158 \mathrm{MPa}(8.5 \mathrm{psig})$ at $286 \mathrm{sec}$. The present model predicts a negative pressure following flame extinguishment of $0.089 \mathrm{MPa}(-1.62 \mathrm{psig})$ at $t=426$ sec. This is somewhat larger than Postma's prediction of $0.0918 \mathrm{MPa}(-1.2$ psig) at $t=540 \mathrm{sec}$.

Parameter variations that depart from the base case values were input to the model and the peak pressure results are shown in Tables 1 to 8 together with the previous results reported by Postma. In almost all cases the present model yields higher $P_{\max }$ values than those calculated by Postma. However the percentage difference between the $P_{\max }$ predictions does not exceed 15 percent. 


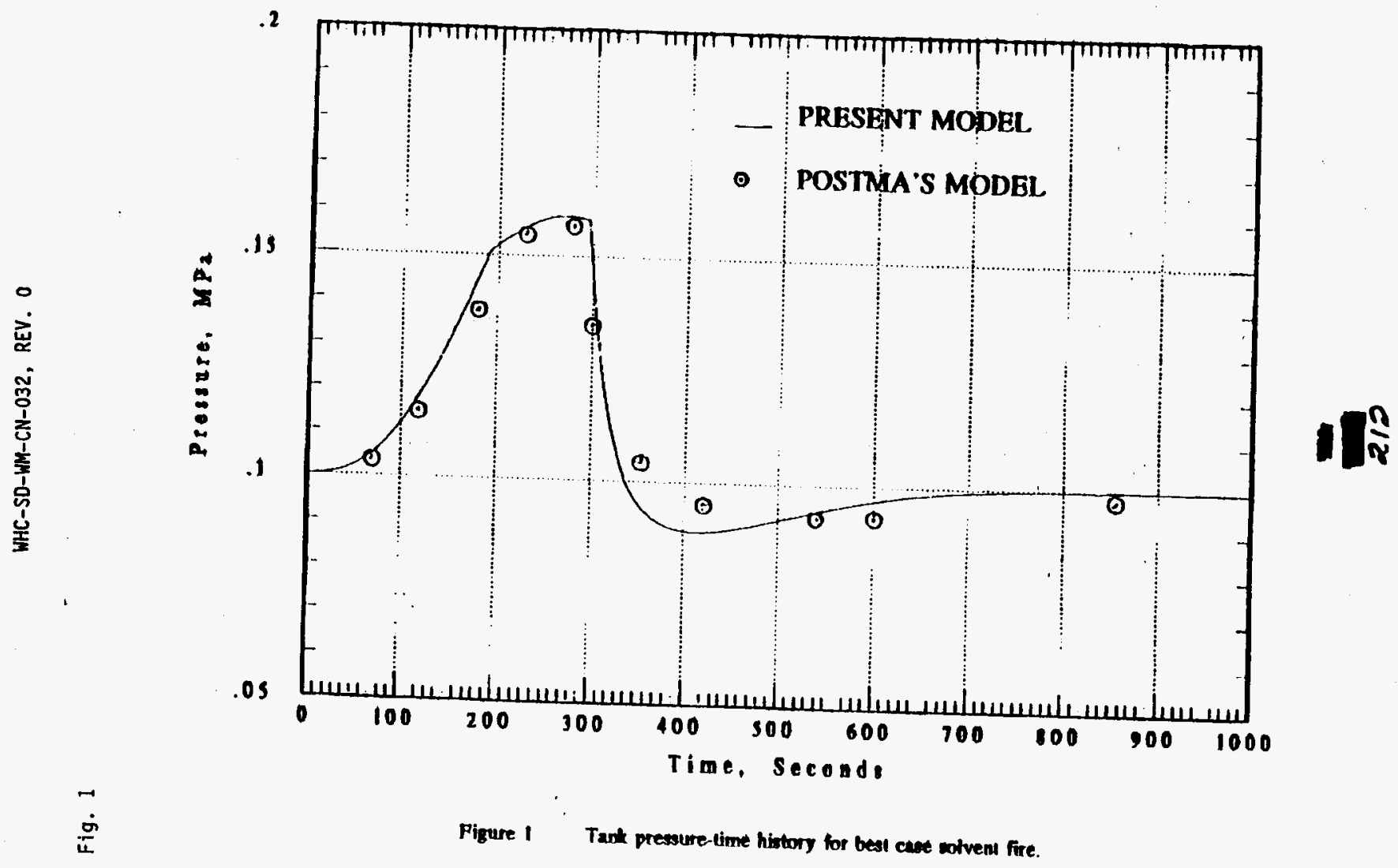


WHC-SD-WM-CN-032, REV. 0

Table 1

Effect of Initial Flame Radius on Peak Pressure

\begin{tabular}{|c|c|c|}
\hline$R_{0}$ (m) & \multicolumn{2}{|c|}{$P_{\max }$ (psig) } \\
\hline & PRESENT MODEL & POSTMA'S MODEL \\
\hline 0.15 & 8.66 & 8.5 \\
\hline 0.31 & 8.67 & 8.5 \\
\hline 0.62 & 8.73 & 8.5 \\
\hline
\end{tabular}

Table 2

Effect of Flame Spread Velocity on Peak Pressure

\begin{tabular}{|c|c|c|}
\hline \multirow{2}{*}{$v_{f}\left(\mathrm{~m} \mathrm{~s}^{-1}\right)$} & \multicolumn{2}{|c|}{$\mathrm{P}_{\max }$ (psig) } \\
\hline & PRESENT MODEL & POSTMA's MODEL \\
\hline \hline 0.001 & 2.24 & 1.8 \\
0.005 & 7.50 & 7.6 \\
0.01 & 8.66 & 8.5 \\
0.02 & 12.82 & 11.9 \\
\hline
\end{tabular}


WHC-SD-WM-CN-032, REV. 0

Table 3

Effect of Pool Radius on Peak Pressure

\begin{tabular}{|c|c|c|}
\hline & \multicolumn{2}{|c|}{$P_{\max }(p$ sig) } \\
\hline$R_{p}(m)$ & PRESENT MODEL & POSTMA ' S MODEL \\
\hline \hline 0.3 & 0.19 & 0.47 \\
1.22 & 4.42 & 3.7 \\
1.72 & 7.36 & 6.4 \\
2.43 & 8.32 & 8.1 \\
3.60 & 8.66 & 8.5 \\
4.87 & 8.66 & 8.5 \\
\hline
\end{tabular}

Table 4

Effect of Venting Sequence on Peak Pressure

\begin{tabular}{|c|c|c|}
\hline \multirow[t]{2}{*}{ VENT SEQUENCE } & \multicolumn{2}{|c|}{$P_{\max }(p s i g)$} \\
\hline & PRESENT MODEL & POSTMA'S MODEL \\
\hline $\begin{array}{l}\text { Salt Well Riser } \\
\text { Opens }\end{array}$ & 8.66 & 8.5 \\
\hline $\begin{array}{l}\text { Salt Well Riser } \\
\text { Does Not Open }\end{array}$ & 13.79 & 12.0 \\
\hline
\end{tabular}


WHC-SD-WM-CN-032, REV. 0

Table 5

Effect of Emissivity on Peak Pressure

\begin{tabular}{||c|c|c|}
\hline \multirow{2}{*}{$\epsilon$} & \multicolumn{2}{|c|}{$\mathrm{P}_{\max }$ (psig) } \\
\hline & PRESENT MODEL & POSTMA'S MODEL \\
\hline 1.0 & 8.44 & 8.4 \\
0.9 & 8.66 & 8.5 \\
0.8 & 8.95 & 8.7 \\
\hline
\end{tabular}

Table 6

Effect of Oxygen Extinguishment Levels on Peak Pressure

\begin{tabular}{||c|c|c|}
\hline & \multicolumn{2}{|c|}{$\mathrm{P}_{\max }$ (psig) } \\
\hline & PRESENT MODEL & POSTMA'S MODEL \\
\hline \hline 0.12 & 8.66 & 8.5 \\
0.142 & 8.66 & 8.5 \\
0.19 & 8.30 & 6.5 \\
\hline
\end{tabular}


WHC-SD-WM-CN-032, REV. O

Table 7

Effect of Specific Burning Rate on Peak Pressure

\begin{tabular}{|c|c|c|}
\hline \multirow{2}{*}{$\begin{array}{c}\dot{\mathrm{m}}_{, \infty}^{*} \\
\left(\mathrm{~kg} \mathrm{~m}^{-2} \mathrm{~s}^{-1}\right)\end{array}$} & \multicolumn{2}{|c|}{$\mathrm{P}_{\max }$ (psig) } \\
\hline & PRESENT MODEL & POSTMA'S MODEL \\
\hline \hline $1.67 \times 10^{-2}$ & 8.22 & 8.4 \\
$2 \times 10^{-2}$ & 8.66 & 8.5 \\
$2.83 \times 10^{-2}$ & 9.63 & 9.3 \\
\hline
\end{tabular}

Table 8

Effect of Combustion Energy on Peak Pressure

\begin{tabular}{|c|c|c|}
\hline$\Delta H\left(\mathrm{~J} \mathrm{~kg}^{-1}\right)$ & \multicolumn{2}{|c|}{$P_{\max }$ (psig) } \\
\hline & PRESENT MODEL & POSTMA'S MODEL \\
\hline $2.89 \times 10^{7}$ & 8.34 & 8.2 \\
\hline $3.3 \times 10^{7}$ & 8.66 & 8.5 \\
\hline $4.13 \times 10^{7}$ & 9.27 & 8.7 \\
\hline
\end{tabular}




\section{Nomenclature}

$A_{\text {eff }}$ Effective area of vent paths

$A_{w} \quad$ Heat transfer surface area in contact with headspace gas $\left(1220 \mathrm{~m}^{2}\right)$

$c_{p} \quad$ Specific heat at constant pressure of headspace gas $\left(1000 \mathrm{~J} \mathrm{~kg}^{-1} \mathrm{~K}^{-1}\right)$

$c_{v}$ Specific heat at constant volume of headspace gas $\left(714 \mathrm{~J} \mathrm{~kg}^{-1} \mathrm{~K}^{-1}\right)$

$D_{i} \quad$ Equivalent diameter of vent $i$

$f_{i} \quad$ Friction factor of vent $i$

$k$ Thermal conductivity of headspace gas $\left(0.04 \mathrm{~W} \mathrm{~m}^{-1} \mathrm{~K}^{-1}\right)$

$L_{i} \quad$ Equivalent length of vent $i$

$\dot{m}_{b} \quad$ Instantaneous solvent burning rate

$\dot{\mathrm{m}}_{\mathrm{B}, \infty}^{*} \quad$ Solvent burning rate per unit area of large inflamed surface

$M_{g} \quad$ Molecular weight of headspace gas (29)

$\dot{m}$ Tank mass venting or suction rate

$P \quad$ Instantaneous pressure of headspace gas

$P_{\max }$ Predicted tank peak pressure

$P_{\infty} \quad$ Atmospheric pressure $(0.1 \mathrm{MPa})$

$r$ Mass of oxygen consumed per mass of fuel burned (3.48)

$\mathrm{R} \quad$ Ideal gas constant ( $8314 \mathrm{~J} \mathrm{kg-mole}{ }^{-1} \mathrm{~K}^{-1}$ )

$R_{f} \quad$ Instantaneous radius of inflamed area

$R_{f, 0} \quad$ Initial radius of inflamed area

$R_{p} \quad$ Radius of solvent pool

$t$ Time measured from solvent ignition

$T$ Instantaneous temperature of headspace gas

$T_{w} \quad$ Temperature of heat transfer (sinks) surfaces $\left(43^{\circ} \mathrm{C}\right.$ )

$T_{\infty} \quad$ Temperature of outside air $\left(27^{\circ} \mathrm{C}\right)$

$\checkmark \quad$ Volume of headspace gas $\left(2600 \mathrm{~m}^{3}\right)$

$v_{f} \quad$ Flame spreading velocity

$Y \quad$ Instantaneous oxygen mass fraction in headspace gas

$Y_{\text {ext }}$ 0xygen extinguishment level mass fraction

$Y_{\infty} \quad$ 0xygen mass fraction in outside air $(0.23)$

$\alpha \quad$ Thermal diffusivity of headspace gas $\left(5.56 \times 10^{-5} \mathrm{~m}^{2} \mathrm{~s}^{-1}\right)$

$\Delta H \quad$ Solvent heat of combustion

$\epsilon \quad$ Effective emissivity of headspace gas-tank wall system

$\checkmark \quad$ Kinematic viscosity of headspace gas $\left(3.79 \times 10^{-5} \mathrm{~m}^{2} \mathrm{~s}^{-1}\right)$ 
$\rho \quad$ Instantaneous density of headspace gas

$\rho_{\infty} \quad$ Density of outside air $\left(1.16 \mathrm{~kg} \mathrm{~m}^{-3}\right)$

$\sigma \quad$ Stefan-Boltzmann constant $\left(5.6 \times 10^{-8} \mathrm{~W} \mathrm{~m}^{-2} \mathrm{~K}^{-4}\right)$

\section{Reference}

Postma, A. K., 1995, in "Risk from Organic Solvent Fires in C-103 Following Interim Stabilization" (et al.), Westinghouse Hanford Report WHC-SD-WM-SARR-001, Supplement 1, Revision 0-A (March).

ME: 1 ak

cc: H. K. Fauske 
WHC-SD-WM-CN-032, REV. 0

ATTACHMENT A-4

APPENDIX D OF WHC-SD-WM-SARR-001, REV. 0, SUPPLEMENT 1 , "CHECKLIST FOR TECHNICAL PEER REVIEW" 
WHC-SD-WM-CN-032, REV. 0

This page intentionally left blank. 
WHC-SD-WM-CN-032, REV. 0

\section{CHECKLIST FOR TECHNICAL PEER REVIEW}

(Sheet 1 of 2)
A.
Document Reviewed: (include complete reference--author, addressee, letterbook number, title or description of calculation, document number, and date, as applicable): Appendix E Potential Consequences of Postulated Solvent Fires in Tank $\mathrm{C}-103$
B. Scope of Review:
Technical review of thermal-hydraulics for burn scenario.

Yes No* NA

[X] [ ] [ ] Problem completely defined.

[X] [ ] [ ] Accident scenarios developed in a clear and logical manner.

[X] [ ] [ ] Necessary assumptions explicitly stated and supported.

[]$[X]$ [ ] Computer codes and data files documented.

[X] [ ] [ ] Data used in calculations explicitly stated in document.

$[X][][$ ] Data checked for consistency with original source information as applicable.

[X] [ ] [ ] Mathematical derivations checked including dimensional consistency of results.

[X] [ ] [ ] Models appropriate and used within range of validity or use outside range of established validity justified.

[X] [ ] [ ] Hand calculations checked for errors. Spreadsheet results should be treated exactly the same as hand calculations.

[ ] [X] [ ] Software input correct and consistent with document reviewed.

[ ] [X] [ ] Software output consistent with input and with results reported in document reviewed.

[X] [ ] [ ] Limits/criteria/guidelines applied to analysis results are appropriate and referenced. Limits/criteria/guidelines checked against references.

[X] [ ] [ ] Safety margins consistent with good engineering practices.

$[X]$ [ ] [ ] Conclusions consistent with analytical results and applicable limits.

[X] [ ] [ ] Results and conclusions address all points required in the problem statement.

[ ] [ ] ** Review calculations, comments, and/or notes are attached.

[X] [ ] [ ] Document approved (i.e., the reviewer affirms the technical accuracy of the document).

[X] [ ] [ ] Traceability

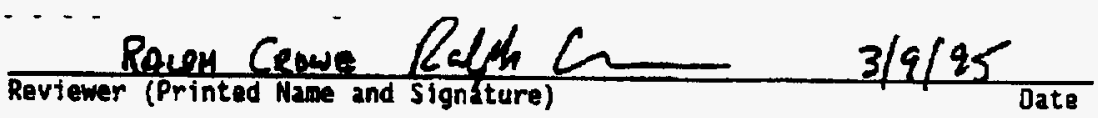

* A11 "N0" responses must be explained below or on an additional page. ** Any calculations, comments, or notes generated as part of this review should be signed, dated and attached to this checklist. Such material should be labeled and recorded in such a manner as to be intelligible to a technically qualified third party.

"No" Response Explanations - Computer code and data files were not reviewed. As a chock, the computer results for the reference case were replicated with hand and spreadsheet calculations with some simplifications. 
WHC-SD-WM-CN-032, REV. 0

This page intentionally left blank. 
WHC-SD-WM-CN-032, REV. 0

\section{ATTACHMENT A-5}

\section{LETTER FROM C. L. BEYLER, HUGHES ASSOCIATES, INC. TO A. K. POSTMA}

This attachment provides independent comments on the appropriateness of the pool fire modeling employed in this study. 
WHC-SD-WM-CN-032, REV. 0

This page intentionally left blank. 


\section{-7ughes Associates, Inc.}

3610 Commeres Dive, Suthe 817, Beftinore, MD 21227-1652

(410) $737-6677$

FAX (410) 737-6688

10 May 1996

Via FAX 1-503-623-0479

Dr. Arlin Postma

G\&P Consulting, Inc.

P.O. Box 576

Richland, WA 99352

Dear Arlin:

I have reviewed your memo of 29 March 1996 regarding the Solvent Fire Analysis for SARR-036. I concur with the resolution of the key issues raised in the memo and your proposed path forward. I very much appreciate the very open and professional manner in which both you and Dr. Grigsby have dealt with issues I had raised with regard to the modeling of the solvent fires. I feel the model as modified as indicated in the memo will be fully able to provide accurate predictions as required in this application. While no model includes every physical and chemical aspect of a problem, this model takes an excellent balanced approach very appropriate to this problem.

The fact that we were able to substantially reproduce some of your predictions using the CFAST model developed by the National Institute for Standards and Technology is significant. As you know, this model includes a two-layer environment rather than a well-stirred model as your model uses, but does not properly deal with compressible flow. The ability to reproduce your results with these differences is indicative of a relatively robust solution which is not heavily dependent on the details of the submodels used for component phenomena.

It is clear from your work and the work we have conducted that DSTs will not reach pressures where structural failure is anticipated, and the SSTs will easily exceed the structural failure limits. This conclusion seems to be quite insensitive to the details of the model and, as such, are quite robust. Of course, if significant additional vent area can be added, pressures can be limited to below the failure limit.

If I can be of further assistance, feel free to contact me. I would appreciate receiving a copy of your report when it is completed. I look forward to working with you in the future.

\section{CLB/cdp}

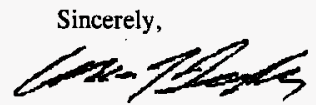

Craig L. Beyler

Technical Director 
WHC-SD-WM-CN-032, REV. 0

This page intentionally left blank. 
WHC-SD-WM-CN-032, REV. 0

APPENDIX B

SCREENING METHODOLOGY FOR SOLVENT FIRE RISK IN SINGLE-SHELL WASTE TANKS AT THE HANFORD SITE 
WHC-SD-WM-CN-032, REV. 0

This page intentionally left blank. 


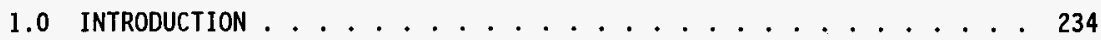

2.0 SUMMARY AND CONCLUSIONS .................... 236

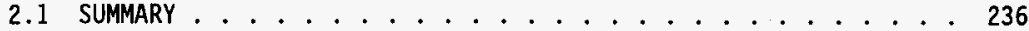

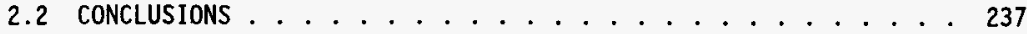

3.0 OBJECTIVE AND SCOPE .................... 239

3.1 OBJECTIVE ....................... 239

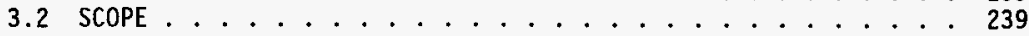

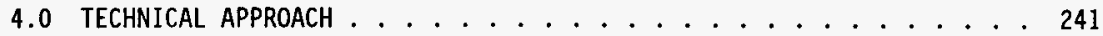

5.0 SOLVENT POOL FIRE HAZARD PHENOMENOLOGY . . . . . . . . . . 243

6.0 TRANSPORT MODELING OF SOLVENT EVAPORATION INTO HEADSPACE AIR . . . 245

6.1 WASTE CONFIGURATION ANALYZED . . . . . . . . . . 245

6.2 MASS TRANSFER RATE OF VAPORS INTO HEADSPACE AIR ...... 245

6.2 .1 Vapor Diffusion in Saltcake ............ 245

6.2 .2 Mass Transport in Tank Headspace . . . . . . . . . . . 248

6.3 ESTIMATION OF POOL AREA ............. . . 249

6.3.1 Surface Pool Versus Submerged Liquid Lense........ . 249

6.3.2 Interfacial Concentration of Solvent Vapors . . . . . 250

6.3.3 Temperature at Solvent/Air Interface ....... 252

6.3.4 Mass Transfer Coefficient at Solvent-Air Interface . . . 254

6.3.5 Ventilation Flow Rate ............. 255

7.0 EXAMPLE SCREENING FOR TWO TANKS .............. 258

7.1 TANK DATA . . . . . . . . . . . . . 258

7.2 SCREENING PARAMETERS . . . . . . . . . . . 258

7.3 COMPARISON WITH $1-\mathrm{m}^{2}$ POOL CRITERION . . . . . . . . 259

8.0 ANALYSIS OF UNCERTAINTIES . . . . . . . . . 261

8.1 MARGIN IN POOL AREA CRITERION . . . . . . . . 261

8.2 INTERFACIAL TEMPERATURE . . . . . . . . . . . . 261

8.3 VOLATILITY OF SOLVENT . . . . . . . . . . . . . . . . 262

8.4 VENTILATION RATE OF HEADSPACE AIR . . . . . . . . . . 265

8.5 MASS TRANSFER COEFFICIENT .............. 265

8.6 AIRBORNE SOLVENT CONCENTRATIONS . . . . . . . . . . . 266

8.7 RESULTS OF MONTE CARLO UNCERTAINTY ANALYSIS . . . . . . . 266

8.8 IMPACT OF HIGH VENTILATION RATES (A-FARM) . . . . . . 268

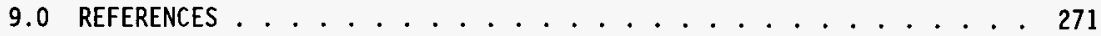


WHC-SD-WM-CN-032, REV. 0

\section{LIST OF FIGURES}

6-1 Schematic of Waste Configuration Analyzed . . . . . . . . . . . 246 
WHC-SD-WM-CN-032, REV. 0

\section{LIST OF TABLES}

6-1 Estimated Composition of NPH Components in Tank C-103 Solvent . . . .251

6-2 Constants for Equation A-9 . . . . . . . . . . . . . . 252

7-1 Example Data for Solvent Pool Fire Hazard Screening . . . . . . . .258

8-1 Properties of Diluents Used at the Hanford Site . . . . . . . . . . 263

8-2 Results From Monte Carlo Analysis of Uncertainties in Pool Area . . 267 
WHC-SD-WM-CN-032, REV. 0

\section{ACRONYMS}

HEPA high-efficiency particulate air

LFL lower flammability limit

NPH normal paraffin hydrocarbon

RAG risk acceptance guideline

SST single-shell tank

TBP tributyl phosphate 
WHC-SD-WM-CN-032, REV. 0

This page intentionally left blank. 
WHC-SD-WM-CN-032, REV. 0

\subsection{INTRODUCTION}

Described in this appendix is a means for identifying single-shell waste tanks (SSTs) that could pose a significant risk from accidental solvent fires. The methodology involves the use of vapor characterization data and an evaporation model to estimate the size of solvent pools that feed vapors into tank vapor spaces. For tanks which fall below a derived pool area criterion, postulated pool fires could not challenge tank structural limits, and would have consequences that fall below applicable risk acceptance guidelines (RAGs).

The ignition of a solvent fire is a very low probability event. However, in studies of pool fires in Tank C-103 (Grigsby 1995) accident sequences have been identified in which gasoline spills and lightning strikes ignite a fire that burns until the oxygen-extinguishment level is reached.

The solvents that present the fire hazard originated from PUREX processing at the Hanford Site during the time period of 1955 to 1986 (Sederburg and Reddick 1994). The solvents were mixtures of hydrocarbon liquids (called diluents) and tributyl phosphate (TBP). Spent solvents ended up in a number of SSTS as waste products.

Recently obtained vapor characterization data (Huckaby 1995a, 1995b) have shown that a number of hydrocarbon species initially present in diluents are present in tank vapor spaces. An implication of this finding is that a liquid phase is present in the tanks and is the source of a fraction of the organic compounds in tank vapor spaces.

The methodology described in this appendix was developed to identify which tanks pose an acceptably small pool fire risk and which tanks require more study to quantify the pool fire risk. Tanks that meet a screening criterion can be judged to meet applicable risk acceptance guidelines (RAGs) without additional evaluation. Tanks that fail the screening criterion may require additional evaluation to quantify the solvent fire risk. 
WHC-SD-WM-CN-032, REV. 0

This page intentionally left blank. 
WHC-SD-WM-CN-032, REV. 0

\subsection{SUMMARY AND CONCLUSIONS}

\subsection{SUMMARY}

The methodology described in this appendix was developed for screening passively ventilated waste tanks with respect to solvent pool fire risk and is based on the following postulates.

- The consequences of postulated pool fires fall within RAGs if the pool area is below a criterion defined on the basis of tank structural units.

- Pool area can be estimated from tank and solvent parameters and measured concentrations of organic vapors in headspace air.

Pool fire analyses applicable to SSTs were carried out to quantify a pool size associated with fire-generated pressures well below those that would challenge tank structural integrity. A pool area of $1 \mathrm{~m}^{2}$ was determined to be a conservative criterion and was used as a basis for the screening methodology presented herein. A more realistic analysis showed that tank structural integrity would not be challenged unless ignited pools exceeded $10 \mathrm{~m}^{2}$ in surface area. The more realistic pool area limit was used to assess a safety margin that accounts for uncertainties in screening parameters.

To determine pool area size in specific tanks, a simple solvent vapor transport model was developed by equating vapor outflow rate in ventilation air to pool evaporation rate. In the resulting equation, pool area is correlated with the concentration of solvent vapors in headspace air. Important parameters in the model are headspace ventilation rate, temperature at the pool surface, mass transfer coefficient for solvent evaporation, volatility of the solvent at a specified temperature, and the concentration of solvent vapors in headspace air.

The model was applied to Tanks BY-104 and BY-108. The results indicated that Tank BY-108 contains a solvent-air interface that exceeds $1 \mathrm{~m}^{2}$ in area. Solvent vapor concentration in Tank BY-104 is below the value conservatively estimated for a $1-\mathrm{m}^{2}$ pool. These two tanks we re selected for analysis for the following reasons. 1. headspace organic vapor concentrations have been measured in these tanks, 2. solid waste compositions and storage temperatures are similar for these two tanks, and 3. organic vapors are present in headspace air in both tanks, but the concentration of organic vapors in Tank BY-108 is appreciably higher than in Tank BY-104.

A Monte Carlo analysis involving 10,000 trials corroborated this conservative deterministic analysis. The analysis which was carried out with the aid of the Crystal $B a l 7^{*+*+a}$ computer program, assessed uncertainties in al1 input parameters and indicated a 99\% certainty that solvent pool area in Tank BY-104 was less than $1 \mathrm{~m}^{2}$.

*Crysta $\mathrm{Ba}$ Cl is a registered trademark of Decisioneering, Inc., Aurora, Colorado 80014. 
WHC-SD-WM-CN-032, REV. 0

Tanks suspected of having solvent pools larger than $1 \mathrm{~m}^{2}$ require additional evaluations to quantify fire risk. These evaluations are necessary because the transport equations used to screen tanks are based on the assumption of a single pool at the waste surface whereas, in reality, the solvent pool could be submerged beneath solid porous waste or could exist as many small localized volumes. Submerged solvent or small isolated pockets of solvent represent a minimal fire risk because ignition and fire spread are much less likely than for a single pool at the waste surface. Thus tanks with pools that modeling indicates are larger than $1 \mathrm{~m}^{2}$, such as Tank BY-108, may not represent an unacceptable pool fire risk. Additional evaluations for these tanks could include visual inspections, surface sampling, and Monte Carlo analysis to quantify the probability that a pool greater than $10 \mathrm{~m}^{2}$ exists.

\subsection{CONCLUSIONS}

The following conclusions characterize the findings of the study described in this appendix.

1. A simple solvent vapor transport model can be used to estimate the air-solvent interfacial area from measured headspace organic concentration and other predictable tank parameters.

2. A pool area of $1 \mathrm{~m}^{2}$ is a conservative criterion for screening tanks for solvent pool fire risk. Pools this size and smaller could not threaten tank structural integrity if ignited and burned to oxygen extinguishment. A more realistic limit of $10 \mathrm{~m}^{2}$ may be used to evaluate safety margin, considering uncertainties in screening parameters.

3. Application of the screening methodology to two SSTs indicates that Tank BY-108 contains a solvent-air interface greater than $1 \mathrm{~m}^{2}$. On the other hand, Tank BY-104 is indicated to have a solvent-air interface smaller than $1 \mathrm{~m}^{2}$. Accordingly, pool fire risk can be discounted for Tank BY-104. Additional evaluations are needed to quantify the risk of a solvent fire in Tank BY-108.

4. The impact of uncertainties in model input parameters for Tank BY-104 was evaluated by means of a Monte Carlo analysis. On the basis of 10,000 trials, the analysis predicted a $99 \%$ certainty that the tank's pool area was $1 \mathrm{~m}^{2}$ or less, thus corroborating the evaporation modeling.

5. The screening methodology appears to be applicable to all SSTs that are passively ventilated. 
WHC-SD-WM-CN-032, REV. 0

This page intentionally left blank. 
WHC-SD-WM-CN-032, REV. 0

\subsection{OBJECTIVE AND SCOPE}

\subsection{OBJECTIVE}

The objective of this study is to develop a screening methodology, based on measured vapor space temperature and organic vapor concentration, that can be used to rank solvent fire risk in Hanford Site waste tanks.

\subsection{SCOPE}

The hazard of focus in this study is a postulated solvent-air fire that could cause tank pressurization and the release of airborne contaminants to the environs. Tanks considered are SSTs that are passively ventilated with atmospheric air, including instrument purge air. 
WHC-SD-WM-CN-032, REV. 0

This page intentionaliy left blank. 


\subsection{TECHNICAL APPROACH}

The technical approach used to develop screening criteria for the solvent fire hazard is based on the following justifiable postulates.

1. Solvent liquids exert an equilibrium vapor pressure at the liquidair interface. Diffusion and convection cause solvent vapors to enter headspace air on a continual basis.

2. The steady-state concentration of solvent vapors in headspace air results from a dynamic equilibrium in which the evaporation rate from liquid is balanced by ventilation outflow.

3. An analysis of mass transfer rates quantifies the interfacial liquid area required to cause a specified concentration of solvent vapor in headspace air.

4. The risk posed by solvent air fires is acceptably small if the solvent pool area is below a size that would generate fire pressures challenging tank structural limits or leading to consequences that exceed applicable RAGs. 
WHC-SD-WM-CN-032, REV. 0

This page intentionally left blank. 
WHC-SD-WM-CN-032, REV. 0

\subsection{SOLVENT POOL FIRE HAZARD PHENOMENOLOGY}

Previous studies of pool fire hazard phenomenology (Grigsby 1995) have identified three key factors of significance to the present study.

1. Solvent fires are low-probability accidents because ignition frequency is very low.

2. Consequences of solvent fires fall within RAGs, provided that the tank is not structurally damaged and the fire does not trigger significant condensed phase reactions. The chief threat to tank structural integrity is internal gas pressure developed by the fire.

3. Peak pressures generated by fires depend heavily on pool surface area, fire spread rate (for large pools), headspace air volume, and flow capacity of tank vents. In the present study, only small pools were considered so spread velocity was relatively unimportant.

A conservative estimate of the pool area required for significant tank pressurization was obtained for this study by analyzing a postulated fire in a $1,000,000$ gal tank with minimal vent openings. Constraints used in the analysis included the following.

- The fire was initiated on a circle $1 \mathrm{ft}(0.3 \mathrm{~m})$ in diameter.

- The fire spread radially at a velocity of $10 \mathrm{~cm} / \mathrm{s}$.

- Vent paths were limited to the U-Tube seal on the high-efficiency particulate air (HEPA) vent riser.

- The duration of the fire was limited by oxygen extinguishment at $13 \% \mathrm{O}_{2}$.

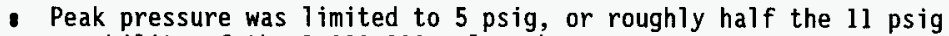
capability of the $1,000,000$-gal tanks .

The analysis indicated that any SST with a solvent pool area of $1 \mathrm{~m}^{2}$ or less poses an acceptably small solvent fire risk. Thus a $1-m^{2}$ area can be used as a preliminary screen to identify tanks that could pose an unacceptable solvent fire risk. For tanks that exceed the $1-\mathrm{m}^{2}$ criterion, more specific and detailed examinations are required to evaluate the fire hazard more realistically. For example, a more realistic determination of vent flow capacity (Grigsby 1995) could increase the allowable pool area by an order of magnitude or more. Alternatively, if visual examination of photographs were to reveal that only entrained solvent was present, then a larger solvent area would be permissible because fires above entrained solids spread less rapidly and have lower specific burn rates than open pool fires. 
WHC-SD-WM-CN-032, REV. 0

This page intentionally left blank. 


\subsection{TRANSPORT MODELING OF SOLVENT EVAPORATION INTO HEADSPACE AIR}

Discussed in this section are the transport models developed to estimate solvent interfacial area on the basis of the temperature and concentration of solvent vapors in headspace air.

\subsection{WASTE CONFIGURATION ANALYZED}

The waste-solvent configuration analyzed is depicted in Figure 6-1. Key assumptions of the modeled waste configuration are as follows.

- Headspace air is passively ventilated by atmospheric pressure fluctuations and by instrument purge air.

- Headspace air is well mixed by natural convection driven by the transport of decay heat across the headspace.

- A solvent pool or submerged liquid lense of an arbitrary plan area is submerged beneath the waste surface by a distance $H$.

- Transport rates in waste are adequately modeled by one-dimensional models.

- Headspace characterization data, including temperature and the concentration of solvent vapors, are available.

\subsection{MASS TRANSFER RATE OF VAPORS INTO HEADSPACE AIR}

Solvent vapors enter the headspace by diffusion from a liquid-air interface. Diffusional transport from an interface, through a porous medium, and then into headspace air is quantified as follows.

6.2.1 Vapor Diffusion in Saltcake The steady-state diffusion flux of organic vapors within a pore of constant cross section is expressible as:

$$
N_{A}=-c D_{A B} \frac{d X_{A}}{d y}+X_{A}\left(N_{A}+N_{B}\right)
$$

where:

$$
\begin{aligned}
N_{A} & =\text { molar flux of } A\left(\text { moles } / \mathrm{s} \mathrm{m}^{2}\right) \\
C & \left.=\text { total gas concentration (moles } / \mathrm{m}^{3}\right)
\end{aligned}
$$


Figure 6-1 Schematic of Waste Configuration Analyzed

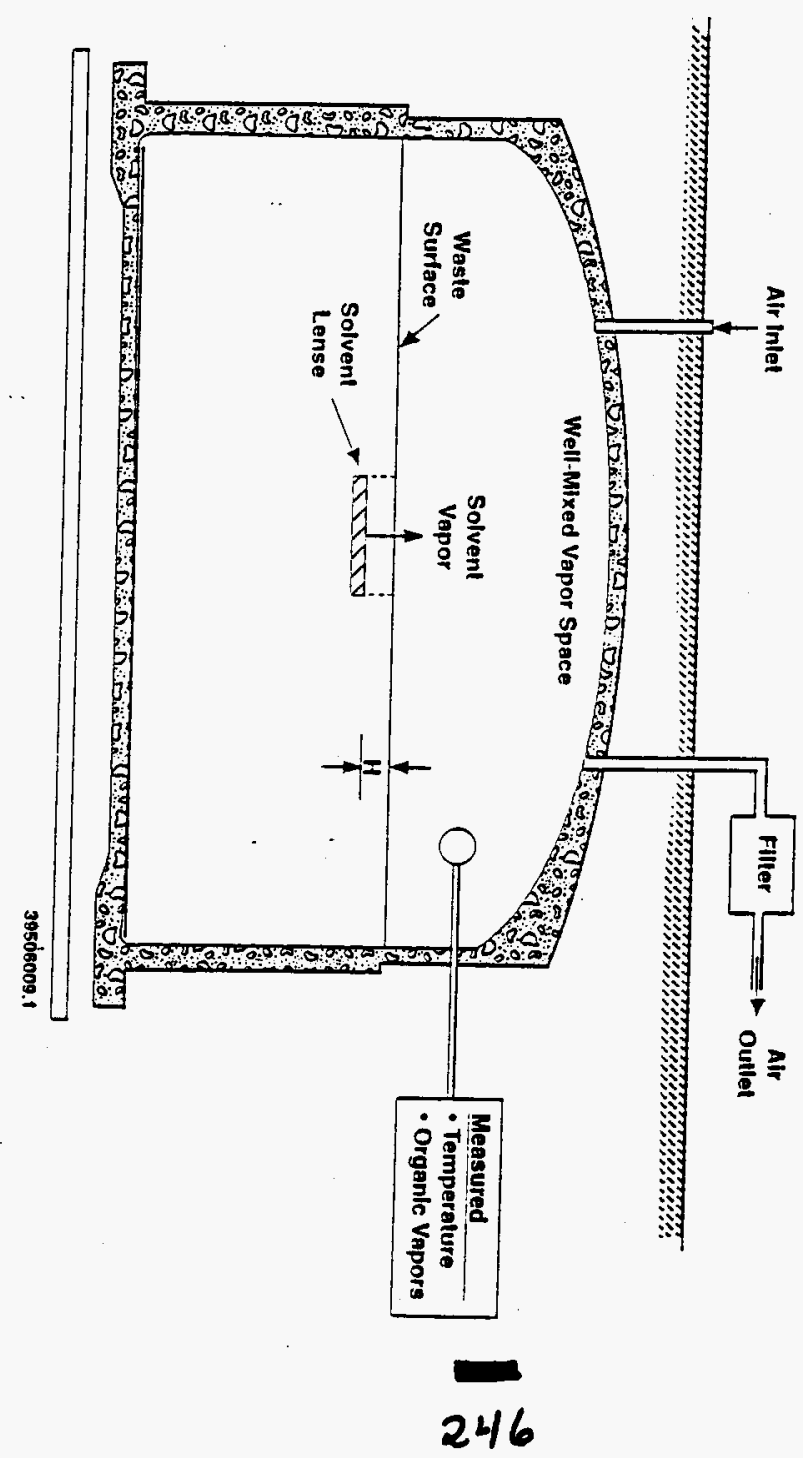




$$
\begin{aligned}
D_{A B} & =\text { diffusivity of } A \text { in } B\left(\mathrm{~m}^{2} / \mathrm{s}\right) \\
X_{A} & =\text { mole fraction of } A \text { in gas }(A+B) \\
y & =\text { distance measured in direction of flux }(\mathrm{m}) \\
N_{B} & =\text { molar flux of } B\left(\text { moles } / \mathrm{s} \mathrm{m}^{2}\right)
\end{aligned}
$$

This equation is taken from Bird et al. 1960. Component $A$ is specified as solvent vapor. Component $B$ is specified as the remainder of the gas, including air, water vapor, and trace levels of radiolytic gases $\left(H_{2}\right.$, $\mathrm{NH}_{3}, \mathrm{~N}_{2} \mathrm{O}$, etc).

The first term on the right hand side of Equation $A-1$ is the flux caused by diffusion. The second term represents the flux caused by bulk flow of the total gas. The magnitude of the bulk flow term, estimated to be small, is neglected in this analysis.

A simplified form of Equation A-1 may be derived by neglecting the bulk flow term $\left[X_{A}\left(N_{A}+N_{B}\right)\right]$; by replacing the product of $C X_{A}$ by the species concentration, $C_{A}$; by evaluating the gradient, $d C_{A} / d y$, as a difference in concentration divided by the diffusion path length; and by introducing porosity and tortuosity factors to account for the diffusional resistance of porous media. The resulting equation may be expressed as follows.

$$
N_{A}=\frac{D_{A B} \epsilon\left(C_{e}-C_{S}\right)}{\tau H},
$$

where:

$$
\begin{aligned}
& \epsilon=\text { porosity of saltcake (dimensionless) } \\
& \tau=\text { tortuosity factor for diffusion (dimensionless) } \\
& H=\text { submergence depth }(\mathrm{m}) \\
& C_{e}=\begin{array}{c}
\text { solvent } \text { vapor concentration in equilibrium with } 1 \text { iquid at } \\
\text { depth }\left(\mathrm{g} / \mathrm{m}^{3}\right)
\end{array} \\
& C_{\mathrm{s}}=\text { solvent vapor concentration at waste surface }\left(\mathrm{g} / \mathrm{m}^{3}\right) .
\end{aligned}
$$

Porosity accounts for the fraction of the solid that is open to gas diffusion, and tortuosity accounts for diffusional resistance caused by nonuniformities in the pore spaces (Sherwood et al. 1975).

The total transport rate of vapor by diffusion in saltcake is the flux, $\mathrm{N}_{\mathrm{A}}$, multiplied by the projected horizontal area of the liquid-air interface. 


$$
W_{A}=N_{A} A,
$$

where:

$$
\begin{aligned}
W_{A} & =\text { diffusional transport rate }(\mathrm{g} / \mathrm{s}) \\
A & =\text { area of liquid lense }\left(\mathrm{m}^{2}\right) .
\end{aligned}
$$

6.2.2 Mass Transport in Tank Headspace $A$ mass balance on solvent vapor in headspace air may be used to relate headspace vapor concentration to the controlling parameters. The rate at which solvent vapors enter headspace air is

$$
\text { input rate }=k_{d}\left(C_{s}-C_{b}\right)^{A} \text {, }
$$

where:

$$
\begin{aligned}
& k_{c}=\text { mass transfer coefficient at waste surface }(\mathrm{m} / \mathrm{s}) \\
& c_{b}=\text { bulk concentration of solvent vapor in headspace air }\left(g / \mathrm{m}^{3}\right) .
\end{aligned}
$$

The rate at which solvent vapors leave the tank headspace due to ventilation air flow is

$$
\text { output rate }=Q C_{b} \text {, }
$$

where:

$$
Q=\text { ventilation rate }\left(\mathrm{m}^{3} / \mathrm{s}\right) \text {. }
$$

Under steady-state conditions (equilibrium conditions in headspace air), input rate equals output rate.

$$
k_{d}\left(C_{s}-C_{b}\right) A=Q C_{b} .
$$

The concentration of solvent vapor at the waste surface, $C_{s}$, can be el iminated as a variable in the analysis by solving Equation $A-\hat{z}$, Equation A-3, and Equation A-6 simultaneousiy. The result may be expressed as 


$$
\frac{C_{\mathrm{b}}}{C_{\theta}}=\frac{k_{\mathrm{c}} A}{k_{\mathrm{c}} A+Q\left(1+\frac{k_{\mathrm{c}} \tau H}{\epsilon D_{A B}}\right)} .
$$

The ratio $C_{b} / C$ expressed in Equation $A-7$ represents the fractional approach of solvent to saturation. In a perfectly sealed tank $(Q=0)$ the right-hand side of Equation A-7 goes to unity, and the vapors are calculated to be saturated. For waste tanks, the ventilation rate is not zero, and $C_{b} / C_{e}$ will always be less than unity, allowing interfacial area, $A$, to be estimated.

Inspection of Equation A-7 reveals that the estimation of $A$ requires that all other parameters be estimable by independent means. Means for estimating the parameters of Equation A-7 are discussed in the following section.

\subsection{ESTIMATION OF POOL AREA}

\subsubsection{Surface Pool Versus Submerged}

Liquid Lense As is evident from Equation A-7, the interfacial area, A, computed on the basis of known or calculable values of $C_{b} / C_{e}, k_{c}, Q, \tau, \epsilon$ and $D_{A B}$, depends on submergence depth, $H$. Thus, for a given tank, the measured solvent vapor concentration could be the result of a surface pool $(H=0)$ or a submerged lense of larger area. Because it is assumed that information on $H$ is not available, $H$ must be assigned a default value that is consistent with a conservative assessment of the solvent fire hazard. The default value is $H=0$; i.e., it is assumed that the liquid solvent exists as an open pool at the surface of the waste. By setting $H=0$, one eliminates the need to quantify the parameters $\tau$ and $\epsilon$ exhibited in Equation A-7.

The assumption that solvent exists as a single surface pool (or surface wetted by a wick) is conservative for the following reasons.

- The ignition of a submerged lense appears to be of much lower probability than the ignition of an open pool or a wick-wetted surface.

- The fire spread rate for liquids submerged in inert porous solids is significantly slower than for surface pools (Wood et al. 1971, Takeno and Hirano 1986).

- The specific burning rate $\left(\mathrm{kg} / \mathrm{m}^{2} \mathrm{~s}\right)$ is slower for submerged pools than for surface pools (Wood et a1. 1971). 
The conservative assumption of $H=0$ allows pool area $A$ to be related to measured or calculable tank parameters. It is recognized that, even though high concentrations or organic vapors are present in a tank, a solvent fire hazard might not exist because the source of the vapors could be submerged liquid that is incapable of supporting a persistent flame. Additional evaluation could be used to show the absence or presence of a surface pool that could sustain a fire.

\subsubsection{Interfacial Concentration of}

Solvent Vapors The mass concentration of solvent vapor in

equilibrium with liquid, $C_{e}$, depends on temperature and the composition of the solvent liquid. In general, experimental data on the present composition of solvents is not available, so an indirect means must be used to estimate $C_{e}$. What is needed is a suitably conservative surrogate solvent with a known vapor concentration-temperature curve. A candidate surrogate is solvent removed from Tank C-103 in 1993 (Pool and Bean 1994). This solvent, a 70:30 mixture (on a mass basis) of TBP and NPH, is stripped of 1 ighter and more volatile fractions and is therefore expected to realistically represent other solvents that may be present in SSTs.

Pool and Bean (1994) measured equilibrium vapor concentrations over the $\mathrm{C}-1031$ iquid at temperatures of $40^{\circ} \mathrm{C}, 70^{\circ} \mathrm{C}$, and $100^{\circ} \mathrm{C}$. These concentration-temperature data were fitted to an integrated form of the Clausius-Clapeyron equation. The resulting equation may be expressed as follows.

$$
\log C_{e}=10.232-\frac{3152.78}{T}
$$

where:

$$
\begin{aligned}
C_{e} & =\text { equilibrium solvent vapor concentration }\left(g / \mathrm{m}^{3}\right) \\
T & =\text { temperature }\left({ }^{\circ} \mathrm{K}\right) . \\
\log & =\text { base } 10 \text { logarithm }
\end{aligned}
$$

Equation A-8 can be used to compute $C_{e}$ for any tank for which the interfacial temperature, $\mathbf{T}$, is known.

An alternative, more conservative (because lower vapor concentration is predicted, resulting in larger predicted pool area) estimate of equilibrium vapor concentration may be obtained by calculating vapor concentrations from Ravolt's Law and pure component vapor pressures for the $c-103$ liquid. The following liquid composition has been derived from measurements reported by Pool and Bean (1994) by grouping unidentified alkanes with identified alkanes having similar chromatographic elution times. 
Table 6-1. Estimated Composition of NPH

Components in Tank C-103 Solvent.

\begin{tabular}{|l|c|}
\hline \multicolumn{1}{|c|}{ Component } & Molecular fraction \\
\hline dodecane & 0.0564 \\
\hline tridecane & 0.2231 \\
\hline tetradecane & 0.1225 \\
\hline pentadecane & 0.0131 \\
\hline tributyl phosphate & 0.5845 \\
\hline \multicolumn{1}{|c|}{ TOTAL } & 0.9996 \\
\hline
\end{tabular}

NPH = normal paraffin hydrocarbon.

Vapor pressures of each of the compounds listed in Table 6-1 may be computed from a three parameter fitting equation:

$$
\log p=A-B /(T+C) \text {. }
$$

where:

$$
\begin{aligned}
\mathbf{P} & =\text { vapor pressure (torr) } \\
\mathrm{A}, \mathrm{B}, \mathrm{C} & =\text { fitting constants } \\
\mathbf{T} & =\text { temperature }\left({ }^{\circ} \mathrm{C}\right) . \\
\log & =\text { base } 10 \text { logarithm }
\end{aligned}
$$

Values of the constants A, B, and C are available from Dreisback (1959) for the alkanes and from Schulz et al. (1984) for TBP. The constants that yield vapor pressures in torr $(\mathrm{mm} \mathrm{Hg}$ ) are 1 isted in Table 6-2. 
Table 6-2. Constants for Equation A-9.

\begin{tabular}{|l|c|c|c|c|}
\hline \multicolumn{1}{|c|}{ Compound } & $\begin{array}{c}\text { Molecular } \\
\text { weight }\end{array}$ & A & B & C \\
\hline dodecane & 170.3 & 7.3157 & 1830.0 & 198.3 \\
\hline tridecane & 184.4 & 7.3147 & 1881.7 & 190.9 \\
\hline tetradecane & 198.4 & 7.3143 & 1930.4 & 183.8 \\
\hline pentadecane & 212.4 & 7.3123 & 1973.3 & 176.6 \\
\hline tributyl phosphate & 266.3 & 8.916 & 3359 & 273.16 \\
\hline
\end{tabular}

NPH = normal paraffin hydrocarbon.

Equilibrium vapor concentrations predicted on the basis of compositions listed in Table 6-1 and the fitting constants listed in Table 6-2 are approximately $50 \%$ of the values predicted from Equation A-8. The difference in predicted and measured vapor concentrations highlights the uncertainty involved in predicting the equilibrium vapor compositions for solvents in waste tanks. A discussion of how solvent composition (volatility) affects screening criteria is presented in Section 8.0 of this appendix.

\subsubsection{Temperature at Solvent/Air}

Interface Temperature at the surface of the waste is higher than bulk gas temperature because a gradient in temperature is linked to the transport of decay heat upward from the waste to the abovegrade atmosphere. The average heat flux in the upward direction can be computed from the mean difference in temperature between the tank headspace and the atmosphere (Crowe et a1. 1993).

$$
\frac{g}{A}=\frac{k_{s}\left(T_{\text {vap }}-T_{a i x}\right)}{\Delta Z},
$$

where:

$$
\begin{aligned}
& \frac{g}{A}=\text { heat flux }\left(\mathrm{W} / \mathrm{m}^{2}\right) \\
& T_{\text {vap }}=\text { annual average bulk headspace air temperature }\left({ }^{\circ} \mathrm{K}\right) \\
& T_{\text {air }}=\text { annual average atmospheric temperature }\left({ }^{\circ} \mathrm{K}\right) \\
& \mathrm{K}_{\mathrm{s}}=\text { thermal conductivity of soil overburden }\left(\mathrm{W} / \mathrm{m}{ }^{\circ} \mathrm{K}\right)
\end{aligned}
$$


$\Delta \mathbf{Z}=$ average depth of soil overburden $(\mathrm{m})$

The formulation expressed in Equation A-10 neglects the small temperature differences that would exist from headspace to dome and from soil surface to atmospheric air. On the basis of information presented by Crowe et al. (1993), $\mathrm{T}_{\text {air }}$ is $\sim 56.3^{\circ} \mathrm{F}\left(286.7^{\circ} \mathrm{K}\right)$, the soil thermal conductivity is

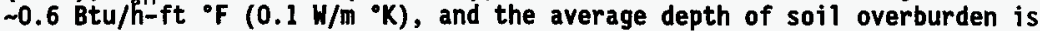
$-13.2 \mathrm{ft}(4.02 \mathrm{~m})$.

The bulk vapor temperature in all SSTs varies with time in response to the annual weather cycle. The annual average tank temperature occurs on approximately July 15 and January 15 (Crowe et al. 1993). Between these dates, tank temperatures experience a sinusoidal variation above and below the average. The maximum and minimum temperatures occur on approximately October 15 and April 15 respectively. The peaks and valleys differ from the yearly average by $\sim 5^{\circ} \mathrm{F}\left(2.8^{\circ} \mathrm{K}\right.$ ) (Crowe et al. 1993). By accounting for the seasonal variation, a value of $T_{\text {yop }}$ applicable to Equation $A-10$ may be computed from a value measured at the time of headspace sampling.

The temperature difference (waste surface-dome surface) that is associated with the heat flux quantified in Equation A-10 may be computed on the basis of standard textbook heat transfer relationships. The flux is equal to a coefficient multiplied by a temperature difference.

$$
\frac{G}{A}=\left(h_{c}+h_{r}\right) \Delta T
$$

where:

$$
\begin{aligned}
& h_{c}=\text { convection heat transfer coefficient }\left(W / m^{2}{ }^{\circ} K\right) \\
& h_{r}=\text { radiation heat transfer coefficient }\left(W / m^{2}{ }^{\circ} K\right) \\
& \Delta T=\text { temperature difference between waste surface and tank dome }\left({ }^{\circ} K\right) \text {. }
\end{aligned}
$$

Numerical evaluations presented by Crowe et al. (1993) indicate that the temperature drop across the headspace (waste surface to dome surface) is relatively smal1, amounting to a few degrees Kelvin or less. Because the gas temperature is intermediate between dome and waste surface temperatures, the surface of a solvent pool will be warmer than the gas temperature by a few degrees or less. Although this temperature difference is sma11, it may not be negligible because vapor pressures are highly sensitive to liquid temperature, as illustrated in Equation A-8. In this study, the liquid interface temperature is computed by subtracting from the bulk gas temperature half of the $\Delta T$ ( $T_{\text {surface }}-T_{\text {dome }}$ ) computed from Equation A-11. 


\subsubsection{Mass Transfer Coefficient at}

Solvent-Air Interface The mass transfer coefficient at the waste-air interface ( $k_{c}$ in Equation A-7) can be estimated on the basis of the ChiltonColburn analogy (Sherwood et al. 1975) by using a correlation of natural convection heat transfer coefficients. For naturally convected heat transfer from heated planar surfaces facing upward, the Nusselt number can be correlated with the Grashov and Prandtl numbers (McAdams 1954). A simplified form of this correlation that applies to large Grashov numbers (1arge surfaces) and normal air temperatures and pressures is presented as the following dimensional equation (McAdams 1954).

$$
h_{c}=1.52 \Delta T^{1 / 6} \text {, }
$$

where:

$$
\begin{aligned}
& h_{c}=\text { convective heat transfer coefficient }\left(\mathrm{W} / \mathrm{m}^{2}{ }^{\circ} \mathrm{K}\right) \\
& \Delta T=\text { temperature difference between surface and bulk air }\left({ }^{\circ} \mathrm{K}\right) .
\end{aligned}
$$

A numerical value of $h_{c}$ can be computed from Equation $A-12$ by using a temperature difference, $\Delta T$, evaluated for a specific tank as described in Section 6.3.3.

The mass transfer coefficient, $k_{c}$, may be computed from the heat transfer coefficient, $h_{c}$, on the basis of the Chilton-Colburn analogy (Sherwood et al. 1975).

$$
k_{c}=\frac{h_{C} D_{A B}}{k}\left(\frac{S C}{P Y}\right)^{1 / 6} \text {, }
$$

where:

$$
\begin{aligned}
k_{c} & =\text { mass transfer coefficient }(\mathrm{m} / \mathrm{s}) \\
h_{c} & =\text { heat transfer coefficient }\left(\mathrm{W} / \mathrm{m}^{2}{ }^{\circ} \mathrm{K}\right) \\
D_{A B} & =\text { diffusivity of solvent vapor }\left(\mathrm{m}^{2} / \mathrm{s}\right) \\
K & =\text { thermal conductivity of gas }\left(\mathrm{H} / \mathrm{m}^{\circ} \mathrm{K}\right) \\
S c & =\text { Schmidt number (dimensionless) } \\
\mathrm{Pr} & =\text { Prandtl number (dimensionless). }
\end{aligned}
$$

Diffusivity of solvent vapor can be estimated from handbook correlations (Perry 1950), as can other gas properties needed to evaluate the parameters of 
WHC-SD-WM-CN-032, REV. 0

Equation A-13. The use of Equations A-10 through A-13 allows one to compute $k_{c}$ as a function of tank headspace temperature.

Equations A-12 and A-13 apply as long as temperature decreases with elevation in the headspace. This condition will persist for tanks that have sufficiently high decay heat loads, but an adverse gradient (temperature increases with elevation) could develop in low heat tanks during summer months. If the adverse gradient existed, then turbulent natural convection would be suppressed, and neither the assumption of a well-mixed headspace nor the applicability of Equations A-12 and A-13 would be assured. Crowe (1996) has performed an analysis of heat cycles in soil covering waste tanks and identified seasonal dates when an adverse temperature gradient could exist. His analysis shows that tanks with heat loads below about 1 kw could experience adverse temperature gradients during summer months. Tank screening should not be based on samples withdrawn from low heat tanks during the periods identified by Crowe (1996).

6.3.5 Ventilation Flow Rate Ventilation flow rate is important because the predicted pool area (see Equation A-7) increases linearly with flow rate. The potential impact of uncertainties in the headspace ventilation rate is discussed in Section 8.0.

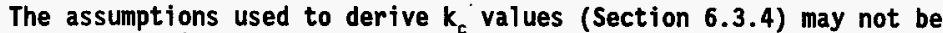
applicable to actively ventilated tanks because tanks that are actively ventilated, such as Tanks $\mathrm{C}-105$ and $\mathrm{C}-106$, have much higher ventilation air flow rates than do passively ventilated tanks. Likewise, tanks like Tank $\mathrm{C}-104$, that are connected to actively ventilated tanks could have ventilation rates significantly higher than these estimated for passive ventilation. Thus, a first step in screening tanks for solvent fire hazard risk is to identify and set aside tanks that are actively ventilated or are connected to actively ventilated tanks. Evaluations for those tanks must account for the higher rates.

The ventilation flow rate in passively ventilated SSTs can be estimated as the sum of atmospheric "breathing" and instrument air purge rate. Atmospheric pressure fluctuations cause a "breathing" ventilation rate amounting to approximately $0.45 \%$ of the headspace air volume per day (Crippen 1993). The instrument air purge rate, on tanks fitted with automatic waste level gauges amounts to $20-50 \mathrm{ft}^{3} / \mathrm{h}\left(0.6-1.4 \mathrm{~m}^{3} / \mathrm{h}\right)$. Tanks that have manual tapes for waste level measurement apparently have no instrument air purge. However, for purposes of screening with respect to solvent fires, it may be assumed that an instrument purge air flow rate of $50 \mathrm{ft}^{3} / \mathrm{hr}$ applies to all passively ventilated SSTs.

Natural convection, i.e., the chimney effect, may cause air flow in addition to flows induced by atmospheric breathing and instrument purge air. The magnitude of natural convective flows in passively ventilated tanks is discussed as follows. Claybrook and Burke (1991) calculated flow rates for Tank C-103 that were five to six times higher than the instrument air purge rate. The higher flows were attributable to a trace-heated exhaust duct and leak paths of significant size at pit covers. These higher flow rates would not be applicable at present because the heated exhaust duct no longer exists 
and the leak paths at pit cover blocks have been sealed. A bounding estimate of natural convective ventilation flow of $7.4 \times 10^{-4} \mathrm{~m}^{3} / \mathrm{s}\left(94 \mathrm{ft}^{3} / \mathrm{h}\right)$ in passively ventilated tanks (Epstein et al. 1994) is roughiy equal to the sum of atmospheric breathing and instrument air purge quantified in the preceding paragraph. Thus, the total ventilation rate, in a tank where natural convection caused a flow of $7.4 \times 10^{-4} \mathrm{~m}^{3} / \mathrm{s}$ to be added to "breathing" and instrument purge air, would be roughly twice the value when natural convection is neglected. The higher flow is probably unrealistic (Dickinson 1995), but may be indicative of upper limit ventilation rates in passively ventilated tanks.

In summary, a realistic estimate of ventilation flow rate in passively ventilated tanks is instrument purge flow plus atmospheric breathing. This estimate is high for tanks that do not use purge air and for tanks in which a lower purge air flow setting is used. An upper bound ventilation rate, based on the analysis of Epstein et al. 1994, would be about double the realistic estimate. A-Farm tanks may be an exceptional case with respect to natural convection, where conditions may foster flow rates higher than the estimate discussed in this section. A-Farm tanks, and the potential impact of uncertainties in headspace ventilation rate are discussed in Section 8.0 . 
WHC-SD-WM-CN-032, REV. 0

This page intentionally left blank. 


\subsection{EXAMPLE SCREENING FOR TWO TANKS}

The screening methodology is illustrated by comparing data sets for two tanks with criteria based on a $1-m^{2}$ open solvent pool.

\subsection{TANK DATA}

Table 7-1.

Tank data relevant to the screening procedure are listed in

Table 7-1. Example Data for Solvent Pool Fire Hazard Screening.

\begin{tabular}{|l|c|c|}
\hline \multirow{2}{*}{ Parameter } & \multicolumn{2}{|c|}{ Numerical value } \\
\cline { 2 - 3 } & Tank BY-108 & Tank BY-104 \\
\hline Total organics $\left(\mathrm{mg} / \mathrm{m}^{3}\right)$ & 527 & 54.7 \\
\hline Headspace temperature $\left({ }^{\circ} \mathrm{C}\right)$ & 25.7 & 26 \\
\hline Headspace volume $\left(\mathrm{m}^{3}\right)$ & 2445 & 2876 \\
\hline
\end{tabular}

The concentration and temperature data in Table 7-1 were obtained by the vapor sampling program currently being conducted by Westinghouse Hanford Company (Huckaby 1995a, 1995b). The total organic concentrations 1 isted in Table 7-1 are maximum sample values reported for temperature and pressures measured at the time of sampling. (Tank BY-108 was sampled on 0ctober 27, 1994 and Tank BY-104 was sampled on December 30, 1994). Headspace temperature reported in Table 7-1 is the lower of that indicated by the sample probe or the permanent thermocouple tree. Headspace volume is calculated by subtracting waste volume from total tank volume.

\subsection{SCREENING PARAMETERS}

Screening is based on Equation 7-1 with $H$ (submergence depth) set equal to zero:

$$
\frac{C_{b}}{C_{\theta}}=\frac{k_{c} A}{k_{c} A+Q} \text {. }
$$

Pool surface area was set equal to $1 \mathrm{~m}^{2}$, the value identified in Section 5.0 as a conservative limit for pool fires. The mass transfer coefficient was evaluated as a function of headspace temperature by using 
Equations $A-11, A-12$, and $A-13$. A $k_{c}$ value of $1.3 \mathrm{~m} / \mathrm{h}$ was calculated for both tanks. The ventilation rate, estimated as the sum of atmospheric breathing $10.45 \%$ of headspace volume per day) and assumed instrument air $\left(1.42 \mathrm{~m}^{3} / \mathrm{h}\right)$ amounted to $2.0 \mathrm{~m}^{3} / \mathrm{h}$ and $1.9 \mathrm{~m}^{3} / \mathrm{h}$ respectively for Tank BY-108 and Tank BY-104. The equilibrium vapor concentration at the liquid-air interface was computed on the basis of ideal gas behavior, the applicability to Rauolt's Law, the composition stated in Table 6-1, and the vapor pressure constants listed in Table 6-2. Interfacial concentrations of $222 \mathrm{mg} / \mathrm{m}^{3}$ and $228 \mathrm{mg} / \mathrm{m}^{3}$ were computed by this means for Tanks BY-108 and BY-104 respectively.

\subsection{COMPARISON WITH $1-\mathrm{m}^{2}$ POOL CRITERION}

For Tank BY-108, the predicted value of bulk headspace organic concentration is

$$
C_{b}=C_{\theta} \frac{k_{c} A}{k_{c} A+Q}=\frac{222(1.3)(1)}{(1.3)(1)+2.0}=87.5 \mathrm{mg} / \mathrm{m}^{3} .
$$

The measured $C_{b}, 527 \mathrm{mg} / \mathrm{m}^{3}$, is well above the predicted value for a $1-\mathrm{m}^{2}$ pool, so this tank is identified as one that could contain a solvent pool having a surface area larger than $1 \mathrm{~m}^{2}$.

For Tank BY-104, the predicted value of bulk headspace organic concentration is

$$
C_{b}=C_{\theta} \frac{k_{c} A}{k_{c} A+Q}=\frac{228(1.3)(1)}{1.3(1)+1.9}=92.6 \mathrm{mg} / \mathrm{m}^{3} \text {. }
$$

The measured $C_{b}, 54.7 \mathrm{~g} / \mathrm{m}^{3}$, is lower than the predicted $C_{b}$ for a $1-\mathrm{m}^{2}$ pool, so this tank falls below the pool area criterion and is therefore assumed to pose an acceptably small fire risk. 
WHC-SD-WM-CN-032, REV. 0

This page intentionally left blank. 


\subsection{ANALYSIS OF UNCERTAINTIES}

The impacts of uncertainties in key tank and solvent parameters on the ranking of tanks with respect to the pool area criterion of $1 \mathrm{~m}^{2}$ is discussed in this section. A quantitative assessment of uncertainties is illustrated by applying a Monte Carlo. trial method to data that apply to Tank BY-104. As discussed in Section 7.0, headspace organic levels in Tank BY-104 were significant, but fell below the level projected for a $1 \mathrm{~m}^{2}$ pool on the basis of a conservative deterministic analysis. The Monte Carlo analysis reported herein was performed with the aid of the Crystal Ball 4.0 computer program.

\subsection{MARGIN IN POOL AREA CRITERION}

The pool area criterion of $1 \mathrm{~m}^{2}$ was identified on the basis of a conservative fire analysis. The analysis was based on a minimal vent path (the U-Tube seal on the HEPA vent pipe) a low peak pressure of $<5$ psid ( 34.5 $\mathrm{kPa}$ ), and conservative fire parameters. A considerably larger pool can realistically be tolerated without over-pressuring a tank, given assumed pool ignition. Fire analyses based on a vent path orifice equivalent to the HEPA vent pipe indicate that a pool of $10 \mathrm{~m}^{2}$ area could pressurize a tank to approximately $11 \mathrm{psig}(75.8 \mathrm{kPa})$, a realistic tank structural limit (Julyk 1994). Thus, the $1 \mathrm{~m}^{2}$ screening criterion is an order of magnitude smaller than a pool which (if ignited) could represent a realistic challenge to tank integrity.

As will be illustrated in the analysis that follows, estimated uncertainties in key parameters lead to predicted pool areas greater than $1 \mathrm{~m}^{2}$ only as a low probability outcome. Realistically, projected pool areas up to $10 \mathrm{~m}^{2}$ do not represent a tank overpressure risk. For projected pools larger than $10 \mathrm{~m}^{2}$, the probability of tank overpressure is assumed to increase. Thus it is important that the screening methodology identify tanks with pool areas greater than $10 \mathrm{~m}^{2}$ with a high degree of certainty.

\subsection{INTERFACIAL TEMPERATURE}

Pool surface temperature is important because vapor pressures of solvents vary strongly with temperature. The temperature at the pool surface is higher than headspace air temperature. This small difference in temperature is required to transfer decay heat from waste surface to tank dome.

\section{Colorado 80014 .}

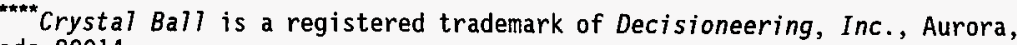


WHC-SD-WM-CN-032, REV. 0

$$
T_{s}=T_{H A}+\Delta T,
$$

where:

$$
\begin{aligned}
T_{s}= & \text { pool surface temperature }\left({ }^{\circ} \mathrm{C}\right) \\
T_{H A}= & \text { headspace air temperature }\left({ }^{\circ} \mathrm{C}\right) \\
\Delta T= & \text { temperature difference between surface of waste and bulk } \\
& \text { headspace air }\left({ }^{\circ} \mathrm{C}\right) .
\end{aligned}
$$

Uncertainties in $T_{s}$ are attributable to both $T_{H A}$ and $\Delta T$. However, the magnitude of $\triangle \mathrm{T}$ is smal9 compared with uncertainties in $\mathrm{T}_{\text {HA }}$; hence the uncertainty in $\mathrm{T}_{\mathrm{s}}$ is governed by uncertainty in $\mathrm{T}_{\mathrm{HA}}$. For Tank $\mathrm{BY}-104, \Delta \mathrm{T}$ was estimated from a heat transfer analysis (Equations A-10, A-11, and A-12) to be $0.4{ }^{\circ} \mathrm{C}$.

Two estimates of $T_{H H}$, obtained on the day of sampling $(6 / 24 / 94)$, are $26.0^{\circ} \mathrm{C}$ and $26.8{ }^{\circ} \mathrm{C}$ (Huckaby 1995a). These temperatures were read from the vapor sampling probe and permanent thermocouple trees respectively. The best estimate of headspace temperature is the average of the two readings:

$$
T_{H A}=\frac{26.0+26.8}{2}=26.4^{\circ} \mathrm{C} \text {. }
$$

From Equation A-15, the best estimate of $T_{s}$ is

$$
T_{s}=26.4+0.4=26.8^{\circ} \mathrm{C} \text {. }
$$

Uncertainty in $T_{s}$ is quantified by assuming a normal distribution with a mean of $26.8{ }^{\circ} \mathrm{C}$ and a standard deviation of $2{ }^{\circ} \mathrm{C}$. The $2{ }^{\circ} \mathrm{C}$ standard deviation is the assumed standard deviation of headspace air temperature measurements alone.

\subsection{VOLATILITY OF SOLVENT}

The word "volatility" is used here to characterize the vapor concentration $\left(\mathrm{mg} / \mathrm{m}^{3}\right)$ in equilibrium with a liquid at a particular temperature. Volatility is not a measured parameter for most tanks and therefore must be estimated from known properties of solvents used at the Hanford Site. 
Solvents used in processing were mixtures of hydrocarbon liquids (called diluents) and TBP. Compositions of three diluents studied by Sederburg and Reddick (1994) are summarized in Table 8-1.

As indicated by the composition data in Table 8-1, vapor species of diluents include cycloparaffins, branched aliphatic hydrocarbons, and normal (straight chain) aliphatic hydrocarbons. The diluent liquids were mixed with TBP (at a diluent ratio of $-30: 70$ on a volumetric basis) to form the solvent.

The volatility of solvents can be quantified on the basis of flashpoints because the flashpoint is the temperature at which the vapor reaches the lower flammability limit. For hydrocarbons of interest, the lower flammability limit is achieved at a vapor mass concentration in the neighborhood of $48 \mathrm{~g} / \mathrm{m}^{3}$ (Zabetakis 1965). The higher the flashpoint, the lower the volatility and conversely.

Table 8-1. Properties of Diluents Used at the Hanford Site*.

\begin{tabular}{|c|c|c|c|}
\hline \multirow[b]{2}{*}{ Property } & \multicolumn{3}{|c|}{ Diluent name } \\
\hline & She11 E-2342 & Soltrol -170 & $\begin{array}{c}\text { Normal paraffin } \\
\text { hydrocarbons }\end{array}$ \\
\hline Period of use & 1955 to $9 / 1961$ & $9 / 1961$ to $2 / 1966$ & $2 / 1966$ to 1989 \\
\hline $\begin{array}{l}\text { Density at } \\
25{ }^{\circ} \mathrm{C}(\mathrm{g} / \mathrm{M} 1)\end{array}$ & .801 & .773 & $.76(\max )$ \\
\hline $\begin{array}{l}\text { Viscosity } \\
\text { (centipoise) } \\
\text { at } 25{ }^{\circ} \mathrm{C} \\
\end{array}$ & 1.7 & 2.3 & 1.8 \\
\hline $\begin{array}{l}\text { Flashpoint } \\
\left({ }^{\circ} \mathrm{F}\right)\end{array}$ & 166 & 192 & 176 (min) \\
\hline Composition & $\begin{array}{l}\text { Approximately } 80 \text { vol\% } \\
5 \text { and } 6 \text { carbon } \\
\text { cycloparrafins } \\
\text { (cyclopentane, } \\
\text { cyclohexane) }\end{array}$ & $\begin{array}{l}\text { Mixture of } \\
\text { highly branched } \\
\text { al iphatic } \\
\text { hydrocarbons }\end{array}$ & $\begin{array}{l}\text { Mixture of } \mathrm{C} 10 \text { to } \\
\text { Cl4 straight } \\
\text { chain aliphatic } \\
\text { hydrocarbons }\end{array}$ \\
\hline
\end{tabular}

"Sederburg, J. P., and J. A. Reddick, 1994.

The flashpoints of diluents 1 isted in Table 8-1 fall in the relatively narrow range of $166^{\circ} \mathrm{F}$ to $192^{\circ} \mathrm{F}$. Thus, volatilities of these diluents are reasonably comparable.

In comparison with fresh solvent $(-30: 70 \mathrm{TBP}$ to NPH), solvent withdrawn from Tank C-103 was enriched in TBP ( $-70: 30$ TBP to NPH) (Pool and Bean 1994). The lower concentration of volatiles is consistent with the stripping of lighter fractions over the decades of storage in Tank C-103. The stripping of volatile solvent components in Tank $\mathrm{C}-103$ has been enhanced by periods of 
forced ventilation.

Uncertainty in solvent volatility can be quantified as follows. First, the concentration-temperature equilibrium curve for the predictive method based on the liquid composition displayed in Table 6-1 is fitted to an integrated form of the Clausius-Clayperon Equation. The result is.

$$
\log C_{e}=13.145-\frac{3229.5}{T},
$$

where:

$$
\begin{aligned}
C_{e} & =\text { equilibrium concentration }\left(\mathrm{mg} / \mathrm{m}^{3}\right) \\
T & =\text { temperature }\left({ }^{\circ} \mathrm{K}\right) .
\end{aligned}
$$

Vapor concentrations predicted by Equation A-16 are approximately half the values measured for solvent taken from Tank $\mathrm{C}-103$. For example, at $70^{\circ} \mathrm{C}$ a concentration of $5,420 \mathrm{mg} / \mathrm{m}^{3}$ is predicted by Equation $\mathrm{A}-16$, as compared with $11,100 \mathrm{mg} / \mathrm{m}^{3}$ indicated by measurements (Pool and Bean 1994).

A best estimate of solvent volatility is made by adding $\log 2$ to the constant term in Equation A-16:

$$
\log C_{m}=13.145+\log 2-\frac{3229.5}{T},
$$

where:

$$
C_{m}=\text { mean value of } C_{e} \text {. }
$$

The range in uncertainty is quantified on the basis of a uniform frequency distribution, with maximum and minimum values of volatility varying from the best estimate by a factor of 4 . Thus the highest volatility would be four times that of solvent in Tank $\mathrm{C}-103$, and the minimum value would be onefourth the value applicable to $\mathrm{C}-103$ solvent. The range in allowed values is a factor of 16, and all values in the range are considered equally probable. This variation was quantified in the Monte Carlo study by assigning maximum and minimum values of 14.0481 and 12.844 respectively to the constant term in Equation A-16. The lower volatility limit quantified in this way is intermediate between that of tetradecane and TBP, two of the less volatile components of NPH. The upper limit is intermediate between that of dodecane and undecane, two of the more volatile components of NPH. The volatility range defined by these limits appears to cover the range of volatilities of solvents that may be present in SSTs and double-shell tanks. 
WHC-SD-WM-CN-032, REV. 0

\subsection{VENTILATION RATE OF HEADSPACE AIR}

Uncertainties in headspace air ventilation rates are quantified by identifying a best estimate value and upper and lower limits thought to apply to passively ventilated tanks. Tanks that are actively ventilated or connected to actively ventilated tanks are excluded from consideration. First, a best estimate value is calculated by adding instrument purge air flow to that caused by atmospheric pressure fluctuations. The best estimate ventilation rate for Tank BY-104 is $1.9 \mathrm{~m}^{3} / \mathrm{h}$ (see Section 7.2). A lower 1 imit on ventilation rate is atmospheric breathing alone; for Tank BY-104 this amounts to

$$
\frac{0.0045}{d} \times \frac{1 d}{24 h} \times 2876 \mathrm{~m}^{3}=0.54 \mathrm{~m}^{3} / \mathrm{h} .
$$

The maximum ventilation rate is estimated as twice the best estimate value, or $2 \times 1.9=3.8 \mathrm{~m}^{3} / \mathrm{h}$. This upper limit is based on a natural convection analysis presented by Epstein et al. (1994) and discussed by Dickinson (1995).

A triangular distribution is assumed to apply. A maximum in freguency is postulated to correspond to the best estimate ventilation rate $\left(1.9 \mathrm{~m}^{3} / \mathrm{h}\right)$. Frequency is prescribed to fall linearly as each limit is approached. Frequency is assigned zero.values for ventilation rates outside the bounds described previously.

\subsection{MASS TRANSFER COEFFICIENT}

The mass transfer coefficient is predicted by available engineering correlations and is expected to be within $20 \%$ to $30 \%$ of the true value. The predicted value of $1.3 \mathrm{~m} / \mathrm{h}$ (Section 7.2) is assumed to be a mean value. The distribution of possible values is assumed to be normally distributed with a standard deviation of $20 \%$ of the mean, or $0.26 \mathrm{~m} / \mathrm{h}$.

Although the mass transfer coefficient depends weakly on temperature, uncertainties in temperature in the gas $f i l m$ above the pool are of the order of $2{ }^{\circ} \mathrm{C}$ and are expected to influence the mass transfer coefficient by only a few percent, a vaiue small compared with uncertainty characterized by a standard deviation of $20 \%$. Therefore, uncertainties in the mass transfer coefficient caused by uncertainties in film temperature have been neglected.

It is assumed in the present study of uncertainties that natural convection correlations based on heat transfer alone apply to solvent pools. However, this assumption should be reviewed in light of the results of an experimental study currently underway to validate the use of natural convection correlations for predicting solvent evaporation rates. The phenomenon being addressed in the study, which is sponsored by Westinghouse Hanford Company, is convection over small pools of volatile liquid with relatively high molecular weights. The vaporized liquid increases air 
density, which acts to oppose natural convection induced by temperature gradients. The adverse density gradient is not explicitly accounted for in the natural convection correlation used in this appendix.

\subsection{AIRBORNE SOLVENT CONCENTRATIONS}

A conservative estimate of airborne solvent vapor concentration is the total nonmethane organic vapor concentration. As noted in Table 7-1, the largest measured value for total organics in Tank BY-104 is $54.7 \mathrm{mg} / \mathrm{m}^{3}$. A second measurement available for this tank yields an estimate of $28.1 \mathrm{mg} / \mathrm{m}^{3}$ (Huckaby 1995a). The average of these values is 41.4 . The two estimates based on sample data values are $32 \%$ higher and lower than the mean.

Solvent vapors constitute only a fraction of the total nonmethane organic compounds found in headspace air. Many of the organic species result from chemical reactions of condensed phase organics as opposed to simple evaporation of solvent 1 iquid. For gas samples withdrawn from Tank BY-104 (Huckaby 1994), the concentration of organic species that are more volatile than $n$-decane is roughly $80 \%$ of the total. Because solvents are composed of decane and higher molecular weight hydrocarbons, the implication is that less than half of the total organics measurement is attributable to solvent vaporization.

The uncertainty in airborne solvent vapor concentration is quantified as follows. First, an upper, bound is set equal to the higher measured value of total organics, $54.7 \mathrm{mg} / \mathrm{m}^{3}$. This upper bound is thought to allow for an error band of $50 \%$ to account for the assumption that $50 \%$ or less of headspace organics derive from solvent evaporation. Second, a best estimate of solvent vapor concentration is based on the average of measured values, divided by two to account for the fraction of the total assumed to be attributable to solvent vapors:

$$
\text { best estimate }=0.5 \frac{(54.7+28.1)}{2}=20.7 \mathrm{mg} / \mathrm{m}^{3} \text {. }
$$

Third, a lower limit on solvent vapor concentration is estimated by dividing the lower measured value by two to account for the solvent vapor fraction: $28.1 \times 0.5=14.1 \mathrm{mg} / \mathrm{m}^{3}$. The frequency distribution is assumed to be of triangular form, with the peak at the best estimate, $20.7 \mathrm{mg} / \mathrm{m}^{3}$. Frequency is prescribed to fall linearly to zero at the upper and lower bounds of $54.7 \mathrm{mg} / \mathrm{m}^{3}$ and $14.1 \mathrm{mg} / \mathrm{m}^{3}$ respectively.

\subsection{RESULTS OF MONTE CARLO UNCERTAINTY ANALYSIS}

The impact of uncertainties in key input variables for Tank BY-104, as quantified in Section 8.2 through 8.6, was analyzed with a Monte Carlo sampling technique. Ten thousand trials were run to predict pool area calculated from a rearrangement of Equation A-7. 
WHC-SD-WM-CN-032, REV. 0

$$
A=\frac{Q}{k_{c}\left(\frac{C_{\theta}}{C_{b}}-1\right)},
$$

where:

$$
\begin{aligned}
A & =\text { pool area }\left(\mathrm{m}^{2}\right) \\
Q & =\text { headspace ventilation rate }\left(\mathrm{m}^{3} / \mathrm{h}\right) \\
k & =\text { mass transfer coefficient }(\mathrm{m} / \mathrm{h}) \\
C_{e} & =\text { equilibrium organic vapor concentration }\left(\mathrm{mg} / \mathrm{m}^{3}\right) \\
C_{b} & =\text { headspace (bulk average) organic vapor concentration }\left(\mathrm{mg} / \mathrm{m}^{3}\right) .
\end{aligned}
$$

The calculations were carried out with Crystal Ball, Version 4.0.

Results from the Monte Carlo analysis are summarized in Table 8-2.

Table 8-2. Results From Monte Carlo Analysis of Uncertainties In Pool Area.

\begin{tabular}{|l|c|}
\hline \multicolumn{1}{|c|}{ Parameter } & Value \\
\hline Trials & 10,000 \\
\hline Mean pool area & $0.17 \mathrm{~m}^{2}$ \\
\hline Median pool area & $0.10 \mathrm{~m}^{2}$ \\
\hline Standard deviation of area & $0.22 \mathrm{~m}^{2}$ \\
\hline Certainty at $1 \mathrm{~m}^{2}$ area & $98.96 \%$ \\
\hline Certainty at $0.47 \mathrm{~m}^{2}$ area & 92.69 \\
\hline Range minimum & $0.01 \mathrm{~m}^{2}$ \\
\hline Range maximum & $4.51 \mathrm{~m}^{2}$ \\
\hline Mean standard error & 0.00 \\
\hline
\end{tabular}

The key result from the uncertainty analysis is that there is a 99\% probability that pool area in Tank BY-104 is less than $1 \mathrm{~m}^{2}$. This high probability is supportive of the conservative deterministic analysis (Section 7.2), which concluded that the area of the solvent pool in Tank BY-104 is less than $1 \mathrm{~m}^{2}$. 
The pool area calculated on the basis of Equation A-18 and the conservative parameters 1 isted in Sections 7.1 and 7.2 is $0.47 \mathrm{~m}^{2}$. The Monte Carlo analysis (Table $8-1$ ), shows that this area corresponds to a $93 \%$ certainty. Thus the deterministic analysis yields an area estimate that has a 93\% chance of being conservative, considering uncertainties in input parameters.

The maximum predicted pool area, $4.51 \mathrm{~m}^{2}$, is of very low probability $(-0.0001)$ and falls below the concern threshold area of $10 \mathrm{~m}^{2}$ (Section 8.1).

Conclusions from this uncertainty analysis are as follows.

- Uncertainty assumptions for input parameters lead to a predicted certainty of $99 \%$ that exposed pool area is $1 \mathrm{~m}^{2}$ or less in Tank BY-104.

- Uncertainties in input parameters do not invalidate the pool area predictions based on the conservative deterministic methodology described in Section 7.0. Therefore the methodology appears to be applicable to other passively ventilated SSTs.

\subsection{IMPACT OF HIGH VENTILATION RATES (A-FARM)}

Temperature and piping in A-Farm cause predicted ventilation rates to exceed the rates assumed to apply to tanks BY-104 and BY-108. A study of ventilation rates in passively ventilated SSTs (Sudasivan et a1. 1995) was focussed on A-Farm because tank piping and temperatures foster ventilation by natural convection. A-Farm contains six $1-m i l l i o n$ gallon $\left(3790 \mathrm{~m}^{3}\right)$ tanks connected with 6-inch $(0.15 \mathrm{~m})$ diameter overflow pipes. Each tank is also vented to the atmosphere through a HEPA filter. Headspace temperatures vary greatly between the six tanks $\left(30^{\circ} \mathrm{C}\right.$ to $\left.89^{\circ} \mathrm{C}\right)$, a condition which promotes air flow via the chimney effect.

A theoretical analyşis (Sudasivan et al. 1995) predicts the highest ventilation rate, $16.1 \mathrm{~m}^{3} / \mathrm{h}(9.5 \mathrm{cfm})$, to occur in Tank A-104. This tank is the highest in temperature of the six, and is connected to Tank A-105 by means of a 6 -inch overflow pipe estimated to be $25 \mathrm{ft} .(7.6 \mathrm{~m})$ in length.

The impact of higher-than-assumed headspace ventilation rate on solvent pool screening is illustrated by applying the screening methodology to Tank A104. First, the concentration of solvent vapors corresponding to a $1 \mathrm{~m}^{2} \mathrm{pool}$ is calculated using the standard flow rate assumption (Section 6.3.5). Parameters of Eq. (A-14) are evaluated as follows.

$$
\begin{aligned}
& A=1 \mathrm{~m}^{2}-\text { area criterion } \\
& k_{c}=2.2 \mathrm{~m} / \mathrm{h}-\text { Eq. (A-13) } \\
& Q=1.42 \mathrm{~m}^{3} / \mathrm{h}+0.0045\left(4960 \mathrm{~m}^{3}\right) / 24 \mathrm{~h}=2.35 \mathrm{~m}^{3} / \mathrm{h}
\end{aligned}
$$

The saturation ratio defined by Eq. (A-14) based on these parameters is: 


$$
\frac{C_{b}}{C_{\theta}}=\frac{2.2(1)}{2.2(1)+2.35}=0.48
$$

This value of $C_{b} / C_{e}$ would represent the saturation ratio which would apply to Tank A-104 screening. If the measured organics were lower than this value, risk from a solvent pool fire would be judged acceptable.

The next step is to assume that organics in Tank A-104 headspace air are equal to the value calculated above $\left(C_{b} / C_{e}=0.48\right)$. We now use our knowledge that ventilation flow rate is higher than assumed and recalculate pool area. Re-arranging Eq.(A-14), pool area is calculated as follows:

$$
A=\frac{Q}{k_{c}\left(\frac{C_{\theta}}{C_{b}}-1\right)}=\frac{16.1}{2.2\left(\frac{1}{0.48}-1\right)}=6.8 \mathrm{~m}^{2}
$$

The pool surface area calculated with the higher ventilation rate is 6.8 $\mathrm{m}^{2}$ versus the $1 \mathrm{~m}^{2}$ used in the screening methodology.

The third step is to determine whether a postulated pool fire (over a 6.8 $\mathrm{m}^{2}$ pool) could threaten structural integrity for this tank. This question was answered by analyzing a pool fire of this size by means of the POOLFIRE.4 code. Vent paths assumed in the fire calculation were the same as assumed in the analysis (Sudasivan et al. 1995) that predicts the $16.1 \mathrm{~m}^{3} / \mathrm{h}$ ventilation rate, namely a HEPA vent pipe and one 6-inch overflow pipe. The equivalent orifice diameter for these two vent paths was estimated to be 7 -inch $(0.18 \mathrm{~m})$. Peak pressure for the $6.8 \mathrm{~m}^{2}$ pool fire was predicted to be 7 psig $(48 \mathrm{kPa})$. A sensitivity case was also run using a pool area of twice $6.8 \mathrm{~m}^{2}$ or $13.6 \mathrm{~m}^{2}$. Peak pressure for the $13.6 \mathrm{~m}^{2}$ pool was calculated to be $10.7 \mathrm{psig}(73.8 \mathrm{kPa})$. Predicted peak pressures for the sensitivity case fall below a tank limit of 11 psig. Thus a fire over a $6-8 \mathrm{~m}^{2}$ solvent pool could be tolerated in tank A104 , with significant margin with respect to structural 1 imits.

In summary, the relatively high ventilation rate thought to apply to tank A-104 would not invalidate conclusions reached on the basis of screening criteria based on a $1 \mathrm{~m}^{2}$ pool area and the standard ventilation rate assumption (Section 6.3.5). Two important factors that make the screening methodology robust are:

(1) The $1 \mathrm{~m}^{2}$ criterion is very conservative with respect to pool size which could generate pressures high enough to threaten tank structural integrity, and

(2) the relatively large air flow paths associated with higher-thanassumed ventilation rates serve as pressure-mitigating vents under postulated fire conditions. 
WHC-SD-WM-CN-032, REV. 0

This page intentionally left blank. 
WHC-SD-WM-CN-032, REV. 0

\subsection{REFERENCES}

Bird, R. B, W. E. Stewart, and E. N. Lightfoot, 1960, Transport Phenomena, John Wiley \& Sons, Inc., New York, New York.

Claybrook, S. W., and T. M. Burke, 1991, Evaporation Modeling for Tank C-103, WHC-SD-WM-ER-127, Rev. 0, Westinghouse Hanford Company, Richland, Washington.

Crippen, M. D., 1993, Barometric Pressure Variations, WHC-EP-0651, Westinghouse Hanford Company, Richland, Washington.

Crowe, R.D., 1996, Simple Method to Predict a Temperature Inversion in a Waste Tank Vapor Space, WHC-SD-WM-CN-027, Westinghouse Hanford Company, Richland, Washington.

Crowe, R. D., M. Kummerer, and A. K. Postma, 1993, Estimation of Heat Load in Waste Tanks Using Average Vapor Space Temperatures, WHC-EP-0709, Westinghouse Hanford Company, Richland, Washington.

Dickinson, D. R., 1995, Origin of Organic Vapors in Tank By-108, Internal Memo 951070RD, April 24, 1995, Westinghouse Hanford Company, Richland, Washington.

Dreisbach, R. R. 1959, "Physical Properties of Chemical Compounds," Advances in Chemistry Series, No. 22, American Chemical Society, Washington, D.C., pp 161-167.

Epstein, M., H. K. Fauske, D. R. Dickinson, M. D. Crippen, J. D. McCormack, R. J. Cash, J. E. Meacham, and C. S. Simmons, 1994, Ferrocyanide Safety Program: An Assessment of the Possibility of Ferrocyanide Sludge Dryout, WHC-EP-0816, Westinghouse Hanford Company, Richland, Washington.

Grigsby, J. M., 1995, Safety Analysis of Exothermic Reaction Hazards Associated with the Organic Liquid Layer in Tank 241-C-103Supplement 1: Risk From Organic Solvent Fires in $\mathrm{C}-103$ Following Interim Stabilization, WHC-SD-WM-SARR-001, Westinghouse Hanford Company, Richland, Washington.

Huckaby, J. L., 1995a, Tank 241-BY-104 Vapor Sampling and Analysis TCR Chapter, Westinghouse Hanford Company, Richland, Washington.

Huckaby, J. L., 1995b, Tank 241-BY-108 Vapor Sampling and Analysis TCR Chapter, Westinghouse Hanford Company, Richland, Washington.

Julyk, L. J., 1994, Static Internal Pressure Capacity of Hanford Single-Shell Waste Tanks", WHC-SD-WM-TI-623, Rev. 0, Westinghouse Hanford Company, Richland, Washington.

McAdams, W. H., 1954, "Heat Transmission", McGraw-Hill, New York.

Perry, R. H., 1950, "Chemical Engineers' Handbook", McGraw-Hill, New York. 
Pool, K. H. and R. M. Bean, 1994, Waste Tank Safety Project: Analysis of Liquid Samples from Hanford Waste Tank 241-C-1-3, PNL-9403, Pacific Northwest Laboratory, Richland, Washington.

Sadasivan, Pratap, B. Nichols, and J. Spore, 1995, Passive Ventilation in Single-She 77 Tanks, LA-UR-95-3453, LoS Alamos National Laboratory, Los Alamos, New Mexico.

Schulz, W. W., J.D. Navratil and A.E. Talbot, 1984, Science and Technology of Tributyl Phosphate, Volume I Synthesis, Properties, Reactions and Analysis, CRC Press, Inc., Boca Raton, Florida, pp 27-28.

Sederburg, J. P. and J. A. Reddick, 1994, TBP and Diluent Mass Balances in the PUREX Plant at Hanford 1955-1991, WHC-MR-0483, Westinghouse Hanford Company, Richland, Washington.

Sherwood T. K., R. L. Pigford, and C. R. Wilke, 1975, Mass Transfer, McGraw Hi11, Inc., New York.

Takeno, K., and T. Hirano, 1986, "Flame Spread Over Porous Solids Soaked With a Combustible Liquid", in Twenty-First Symposium (International) on Combustion, The Combustion Institute, 1986, pp. 75-81.

Wood, B. D., P.L. Blackshear, Jr., and E.R.G. Eckert, 1971, "Mass Fire Model: An Experimental Study of the Heat Transfer to Liquid Fuel Burning from a Sand-Filled Pan Burner," Combustion Science and Technology, Vol. 4, pp. 113-129.

Zabetakis, M. G., 1965, Flammability Characteristics of Combustible Gases and Vapors, Bulletin 627, U.S. Department of the Interior, Bureau of Mines, Washington, D.C. 
WHC-SD-WM-CN-032, REV. 0

This page intentionally left blank. 
WHC-SD $=W M-C N-032$, REV. O

\section{CHECKLIST FOR PEER REVIEW}

Document Reviewed: WHC-SD-WM-CN-032, Analysis of Consequences of Postulated Solvent Fire in Hanford Site Waste Tanks.

Scope of Review: Document reviewed without appendices, based on information supplied. Appendices $A$ and $B$ were reviewed by others as part of a separate document. See WHC-SD-WM-SARR-036, Organic Solvent Topical Report.

Yes No NA

[] [] [A * Previous reviews complete and cover analysis, up to scope of this review, with no gaps.

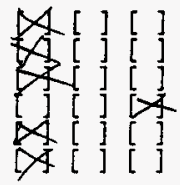

Problem completely defined.

Accident scenarios developed in a clear and logical manner. Necessary assumptions explicitiy stated and supported.

Computer codes and data files documented.

Data used in calculations explicitly stated in document.

Data checked for consistency with original source information as applicable.

Q4 [ ] [ ] Mathematica] derivations checked including dimensional consistency of results.

D4 [ ] [ ] Models appropriate and used within range of validity or use outside range of established validity justified.

DA [ ] [ ] Hand calculations checked for errors. Spreadsheet results should be treated exactly the same as hand calculations.

[][]$[B$ Software input correct and consistent with document reviewed. Software output consistent with input and with results reported in document reviewed.

\&[1] $]$ Limits/criteria/guidelines applied to analysis results are appropriate and referenced. Limits/criteria/guidelines checked against references.

[ ] [ ] Safety margins consistent with good engineering practices. [1] [ ] Conclusions consistent with analytical results and applicable fA[ ] [ ] Results and conclusions address all points required in the problem statement.

[ ] [ ] $\$ Format consistent with appropriate NRC Regulatory Guide or other standards

[ ] $\triangle A^{*}$ Review calculations, comments, and/or notes are attached.

$\otimes[1]$ [ ]

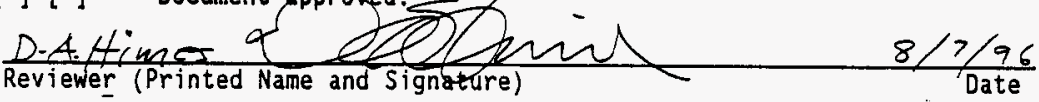

* Any calculations, comments, or notes generated as part of this review should be signed, dated and attached to this checklist. Such material should be labeled and recorded in such a manner as to be intelligible to a technically qualified third party. 


\section{DISTRIBUTION SHEET}

\begin{tabular}{|c|c|c|c|c|c|}
\hline \multirow{2}{*}{$\begin{array}{l}\text { To } \\
\text { Distribution }\end{array}$} & \multirow{2}{*}{\multicolumn{3}{|c|}{$\begin{array}{l}\text { From } \\
\text { W. L. Cowley }\end{array}$}} & \multicolumn{2}{|l|}{ Page 1 of 1} \\
\hline & & & & \multicolumn{2}{|l|}{ Date $8 / 9 / 96$} \\
\hline \multicolumn{4}{|l|}{ Project Title/Work Order } & \multicolumn{2}{|c|}{ EDT No. 142244} \\
\hline \multicolumn{4}{|c|}{$\begin{array}{l}\text { Analysis of Consequences of Postulated Solvent Fires in Hanford } \\
\text { Site Tanks. }\end{array}$} & \multicolumn{2}{|c|}{ ECN No. N/A } \\
\hline Name & MSIN & $\begin{array}{c}\text { Text } \\
\text { With All } \\
\text { Attach. }\end{array}$ & Text Only & $\begin{array}{l}\text { Attach./ } \\
\text { Appendix } \\
\text { Only }\end{array}$ & $\begin{array}{c}\text { EDT/ECN } \\
\text { Only }\end{array}$ \\
\hline $\begin{array}{l}\text { C. Carro } \\
\text { D. S. Leach } \\
\text { W. L. Cowley (5) } \\
\text { D. A. Himes } \\
\text { J. E. Meacham } \\
\text { TWRS S\&L Project Files (5) } \\
\text { Central Files (Original }+2 \text { ) }\end{array}$ & $\begin{array}{l}\text { A2-34 } \\
\text { A3-34 } \\
\text { A3-37 } \\
\text { A3-34 } \\
\text { S7-14 } \\
\text { A2-26 } \\
\text { A3-88 }\end{array}$ & $\begin{array}{l}x \\
x \\
x \\
x \\
x \\
x \\
x\end{array}$ & & & \\
\hline
\end{tabular}

